\title{
CARINA ULSEN
}

\section{CARACTERIZAÇÃO TECNOLÓGICA DE RESÍDUOS DE CONSTRUÇÃO E DEMOLIÇÃO}

Dissertação apresentada à Escola Politécnica da Universidade de São Paulo para obtenção do título de mestre em Engenharia.

São Paulo

2006 


\section{CARINA ULSEN}

\section{CARACTERIZAÇÃO TECNOLÓGICA DE RESÍDUOS DE CONSTRUÇÃO E DEMOLIÇÃO}

Dissertação apresentada à Escola Politécnica da Universidade de São Paulo para obtenção do título de mestre em Engenharia.

Área de Concentração:

Engenharia Mineral.

Orientador:

Prof. Dr. Henrique Kahn

São Paulo

2006 
Este exemplar foi revisado e alterado em relação à versão original, sob responsabilidade única do autor e com a anuência de seu orientador.

São Paulo, de setembro de 2006.

Assinatura do autor

Assinatura do orientador

FICHA CATALOGRÁFICA

Ulsen, Carina

Caracterização tecnológica de resíduos de construção e demolição / C. Ulsen. -- ed.rev. -- São Paulo, 2006.

$171 \mathrm{p}$.

Dissertação (Mestrado) - Escola Politécnica da Universidade de São Paulo. Departamento de Engenharia de Minas e de Petróleo.

1.Resíduos de construção (Caracterização tecnológica) 2.Entulho reciclado I.Universidade de São Paulo. Escola Politécnica. Departamento de Engenharia de Minas e de Petróleo II.t. 


\section{DEDICATÓRIA}

Uma dedicatória...

Aqueles que um dia forem capazes de...

sonhar mais que um sonho impossivel,

lutar quando é fácil ceder,

vencer o inimigo invencível,

negar quando a regra é vender,

sofrer a tortura implacável,

romper a incabível prisão,

voar no limite provável,

tocar o inacessivel chão.

É minha lei, é minha questão,

virar este mundo, cravar este chão,

não me importa saber se é terrível demais,

quantas guerras terei de vencer,

por um pouco de paz.

E amanhã,

se este chão que eu beijei

for meu leito e meu perdão,

vou saber que valeu delirar

e morrer de paixão.

E assim, seja lá como for, vai ter fim a infinita aflição,

$e$ o mundo vai ver uma flor

a brotar do impossível chão.

Às pessoas que lutam veementemente pelo mesmo ideal: o desenvolvimento da ciência e a ajuda ao mundo do terceiro milênio, que não importam os obstáculos não desistem de lutar pelo ideal que acreditam: aos psicanalistas Dr. Keppe e Dra. Cláudia Pacheco e ao pesquisador Sérgio C. Ângulo: minha sincera admiração. 


\section{AGRADECIMENTOS}

O começo do trabalho foi um tanto particular, eu não queria trabalhar com algo comum, qualquer tema somente para dizer que estava trabalhando. Motivada por um livro infantil que lera na mina infância "50 COISAS SIMPLES QUE AS CRIANÇAS PODEM FAZER PARA SALVAR A TERRA”, queria de qualquer maneira um tema ligado à ecologia, que contribuísse para o mundo mudar de diretriz e não para a catástrofe para que está caminhando; foi quando o comecei a trabalhar com o professor Henrique Kahn e não parava de atormentá-lo com a idéia fixa do que queria. Na mesma época o então mestre em engenharia Sérgio Ângulo iniciava suas atividades de doutorado na área que eu procurava sob co-orientação do mesmo professor. Coincidência? Desde então tive a satisfação de trabalhar no projeto desde maio de 2002, e não paramos de ser reconhecidos pelas atividades desenvolvidas, ganhei todos os prêmios que um aluno de graduação pode almejar, levamos o assunto a Congressos e publicações internacionais, e acima de tudo, tivemos o prazer de trabalhar e aprender com as pessoas que participaram do desenvolvimento deste estudo.

Agradeço a Deus acima de tudo pela saúde de poder trabalhar até $280 \mathrm{~h} /$ mês e me ajudar a sair do fundo do poço quando tudo parecia inviável.

Obrigada pela família que tenho - quem conhece sabe do que estou falando; sempre digo que Deus fez uma família tão maravilhosa que resolveu me colocar no meio dela para causar certo tumulto.

Obrigada aos amigos por ter me suportado, mesmo sendo tão desnaturada, ausente por todo esse tempo, vocês no fundo sabem que são insubstituíveis.

Ao pessoal da SITA (Sociedade Integral de Trilogia Analítica) pela pontinha de conhecimento sobe a psique humana que pude adquirir e dessa forma tornar mais harmoniosa a convivência com meu eu interior.

Ao time de vôlei da Poli e da USP e também à atlética, agradeço pela disciplina, determinação, garra e trabalho em equipe que desenvolvemos juntas. 
À toda equipe do LCT e do LTM que assistiu desde o princípio os meus trabalhos, os dias de Natal em que trabalhava, os finais de semana, dia das mães, madrugadas...valeu a pena! Agradeço às pessoas que me alertavam quanto aos riscos de se abdicar da vida pessoal em prol do trabalho...valeu a pena!

Aos mestres; se todos os dias ao darem aula vocês relembrassem a importância que têm na formação dos alunos! Me fascina pensar que vocês iluminam o caminho de centenas/milhares de pessoas por toda a vida profissional.

Aos demais funcionários do Departamento que sempre se me ajudaram, com palavras, com sorrisos, com piadinhas, com abraços, com broncas e críticas...nos divertimos muito em meio aos tropeços, às lamas e aos erros.

Agradeço por ter conhecido pessoas como José Lancaster, hoje CEO da Vale do Rio Doce, pessoas simples que trabalham com entusiasmo e amor à profissão e não desistem dos sonhos.

Em especial, Sérgio e Henrique: não é possível imaginar qual teria sido meu rumo sem a participação de vocês, talvez agora eu estivesse trabalhando em bancos e enriquecendo sem produzir absolutamente nada, a não ser juros.

Deixo aqui uma memória do que se passou; o trabalho não está perfeito, não é o melhor que eu poderia fazer, mas é o melhor eu pude fazer dentro de um contexto. Estou certa de que foi desenvolvido com muito carinho.

\author{
“ESCOLA, ESCOLA DA MINHA VIDA, MINHA PAIXÃO QUERIDA, \\ POLI-USP MEU AMOR"
}




\section{RESUMO}

Os resíduos de construção e demolição (RCD) representam cerca de $50 \%$ de todo o resíduo sólido gerado, sendo que cerca de $90 \%$ deste é de origem mineral e pode ser reciclado através de processos de beneficiamento mineral. Para se atingir a reciclagem massiva torna-se imperativo o desenvolvimento de novos mercados e melhorias de usina capazes de tornar o resíduo uma matéria prima de qualidade adequada. Dessa forma a caracterização tecnológica é imprescindível para obtenção de informações fundamentais sobre o processo de beneficiamento e as especificações para os produtos.

O programa experimental foi desenvolvido em três amostras de RCD britados de duas usinas de reciclagem do Estado de São Paulo, Itaquera cinza (IT-C), Itaquera vermelho (IT-V), Vinhedo vermelho (VI-V). As atividades desenvolvidas foram: amostragem, cominuição, determinação das composições químicas e mineralógicas por faixa granulométrica, determinação de propriedades físicas relevantes para reciclagem de RCD como agregados para uso em concreto, determinação das curvas de separabilidade por densidade e análise de sua composição química e mineralógica e estudos microscópicos para avaliação do teor de aglomerantes por faixa densitária.

Os resultados de análises químicas mostram que as composições químicas das três amostras são semelhantes; os teores variam com a granulometria, com marcantes diferenças na fração mais fina. A composição mineralógica predominante é de silicatos, provenientes de agregados e rochas naturais, cerâmicas e aglomerantes, com menores teores de alumina e óxido de cálcio; a perda ao fogo está diretamente relacionada ao teor de aglomerantes, uma vez que representa a água combinada e o gás carbônico presente.

A separação do RCD em classes de densidade permitiu identificar que os produtos obtidos apresentam composições diferentes e pode ser empregada para se obter agregados de melhor qualidade e, portanto, para aplicações mais nobres, uma vez que se verifica que cerca de $80 \%$ em massa dos resíduos possuem densidades superiores a $2,2 \mathrm{~g} / \mathrm{cm}^{3}$ com qualidades físicas adequadas para uso em concreto estrutural. 
Adicionalmente, a massa específica aparente e absorção de água estão diretamente relacionadas com os intervalos de densidade. O teor de aglomerantes aumenta significativamente para os produtos de menor densidade, sendo que as partículas cerâmicas estão isentas de pasta de cimento endurecida e cal. 


\section{ABSTRACT}

Construction and demolition waste (CDW) represents around $50 \%$ of the total solid waste and are essentially constituted by mineral fraction $(>90 \%)$; therefore it's possible to recycle it through mineral processing techniques. The development of different uses and the improvement of the typical technologies applied to CDW recycling are essential to achieve a satisfactory level of recycling. Applied mineralogy tools are fundamental to characterize the studied raw material and support the mineral processing in order to obtain products according to its specifications.

This research was carried out in three crushed samples from two different plants close to Sao Paulo; they were named according to its classification: grey Itaquera (IT-C), red Itaquera (IT-V) and red Vinhedo (VI-V). The method involved basically sampling, crushing, characterization of the relevant physical properties for a concrete recycled aggregate approach, evaluation of the specific gravity separability curves and chemical and mineralogical analyses for each grain size fraction and gravity classes, and so microscope analyses to verify the binder contents.

The results show that the chemical composition of the three samples is very similar, the grades change according to the grain size fractions, specially for the finest fraction. The mineral composition is also quite akin, it is mostly represented by silicates (mainly aggregates and natural rocks), ceramics and binder; minor amounts of $\mathrm{Al}_{2} \mathrm{O}_{3}$ and $\mathrm{CaO}$ were also detected. The loss of ignition is directly related to the binder and clay minerals (basically $\mathrm{OH}$ and $\mathrm{CO}_{2}$ ).

Specific gravity classes are very different regarding their chemical, mineralogical and physical properties, despite their similarity among the samples. Thus the specific gravity separation is more effective to classify the recycled CD debris than its color and could be applied to obtain high quality recycled aggregates, while a significant amount $(80 \%)$ is recovered above $2.2 \mathrm{~g} / \mathrm{cm}^{3}$ and may be used as high strength concrete aggregates. In addition, the physical properties, like specific gravity and water absorption are strictly related to the specific gravity classes. 


\section{SUMÁRIO}

página

FICHA CATALOGRÁFICA.......................................................................III

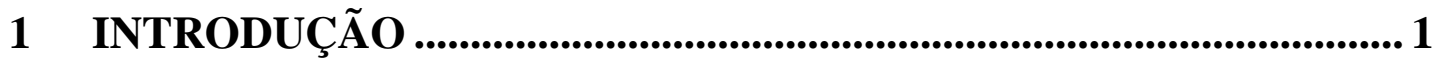

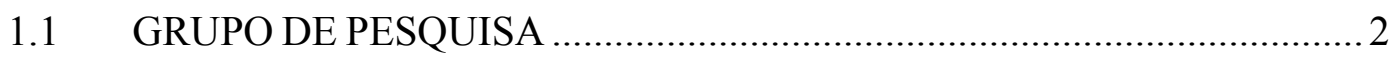

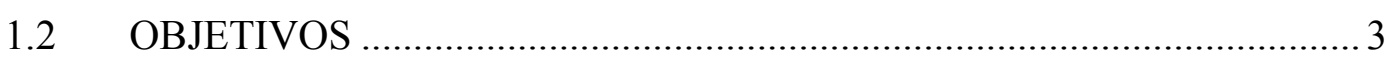

1.3 ESTRUTURA DA DISSERTAÇÃO ........................................................ 4

1.3.1 Capítulo 1 - Introdução .......................................................................... 4

1.3.2 Capítulo 2 - Revisão Bibliográfica........................................................... 4

1.3.3 Capítulo 3 - Procedimento experimental ................................................ 4

1.3.4 Capítulos 4 a 7 - Resultados e discussões............................................... 4

1.3.5 Capítulo 8 - Considerações finais ........................................................ 4

2 REVISÃO BIBLIOGRÁFICA........................................................ 5

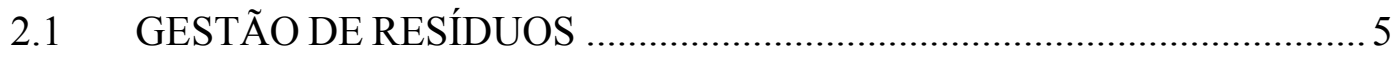

2.1.1 Resíduos de construção e demolição ........................................................ 5

2.1.2 Geração de RCD................................................................................ 5

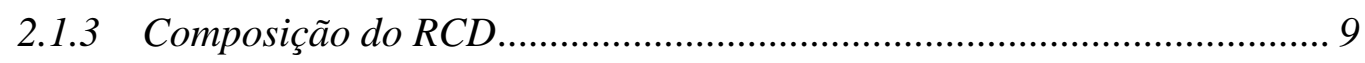

2.1.4 Classificação do RCD para reciclagem como agregado....................... 12

2.1.5 Gerenciamento e reciclagem do RCD................................................. 13

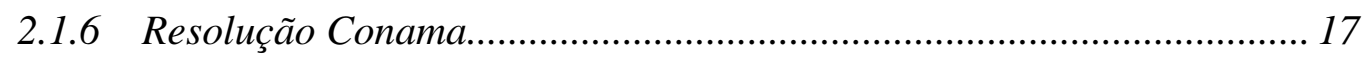

2.2 POSSIBILIDADES DE APLICAÇÕES PARA RECICLADOS DE

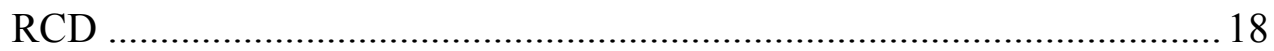

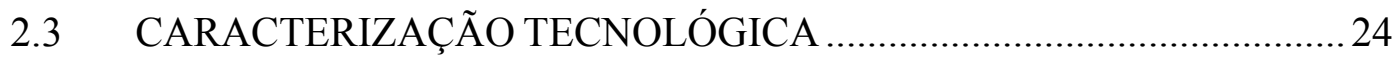

2.3.1 Caracterização de matérias primas minerais......................................... 24

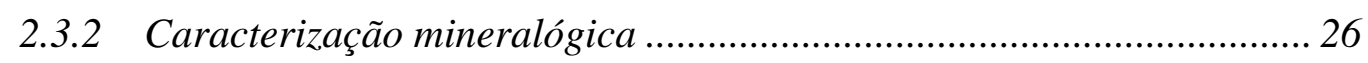

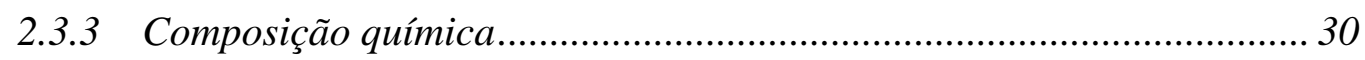

2.3.4 Técnicas de separações minerais............................................................ 31

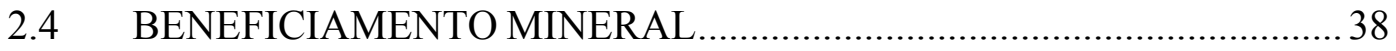

2.5 RECICLAGEM DA FRAÇÃO MINERAL DE RCD ............................... 39 
2.5.1 Contextos nacional e internacional 40

2.5.2 Concentração gravítica dos agregados de RCD reciclados.................. 47

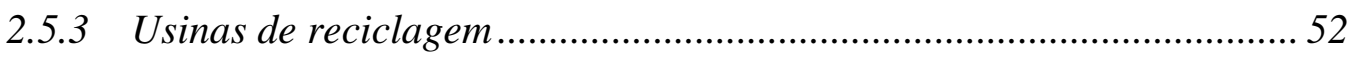

2.6 USINAS DE RECICLAGEM ESTUDADAS ...........................................57

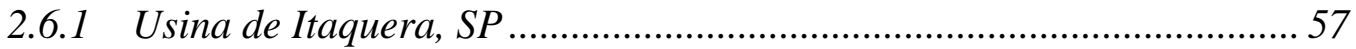

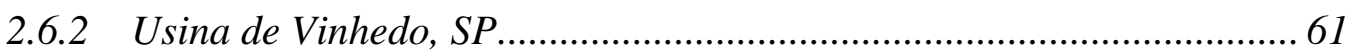

3 PROCEDIMENTO EXPERIMENTAL ....................................... 64

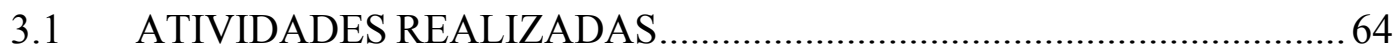

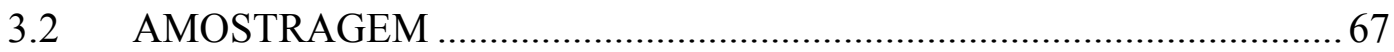

3.3 ANÁLISE GRANULOMÉTRICA E BRITAGEM SECUNDÁRIA..........69

3.4 CARACTERIZAÇÃO QUÍMICA ........................................................ 71

3.5 SEPARAÇÃO EM LÍQUIDOS DENSOS - CURVA DE

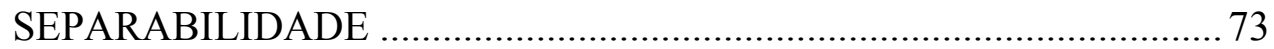

3.6 CARACTERIZAÇÃO MINERALÓGICA.................................................. 76

3.7 CARACTERIZAÇÃO MICROESTRUTURAL DE PRODUTOS DE

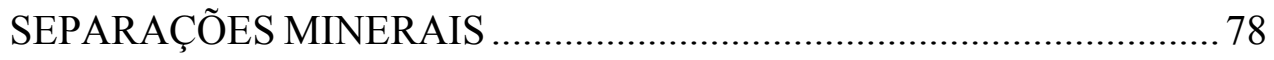

3.8 CARACTERIZAÇÃO DAS PROPRIEDADES FÍSICAS ....................... 78

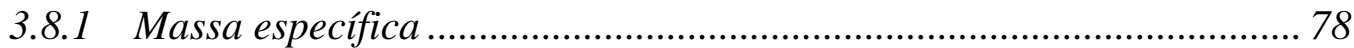

3.8.2 Absorção de água e massa específica aparente...................................... 80

4 ANÁLISE GRANULOQUÍMICA......................................................8 83

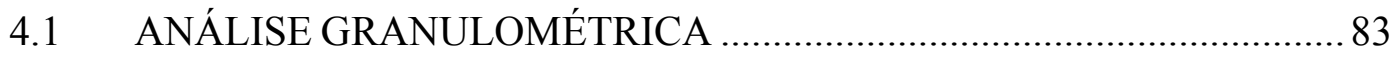

4.2 COMPOSIÇÃO QUÍMICA POR FRAÇÃO.............................................. 86

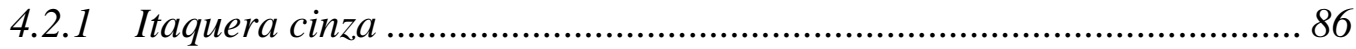

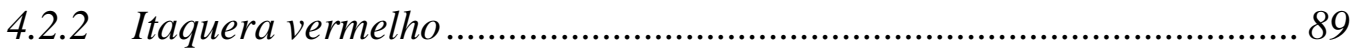

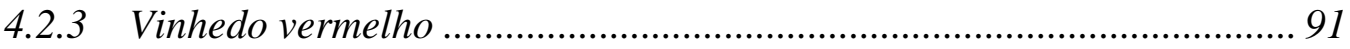

4.2.4 Sumário da composição química dos produtos por fração

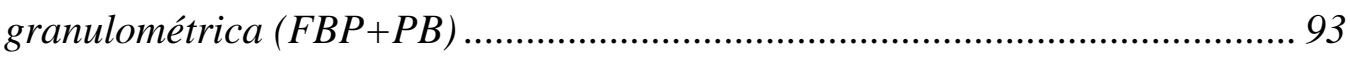

5 SEPARAÇÃO EM LÍQUIDOS DENSOS.......................................... 100

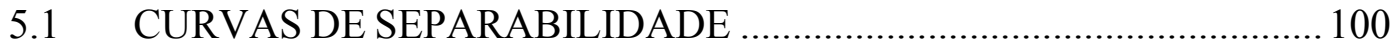

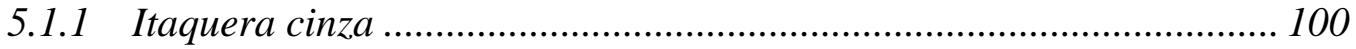

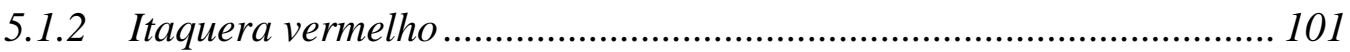




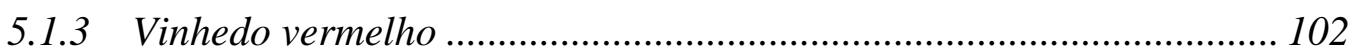

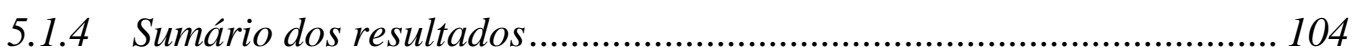

5.2 COMPOSIÇÃO QUÍMICA POR FAIXA DENSITÁRIA........................ 105

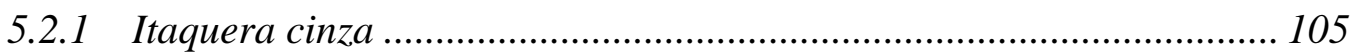

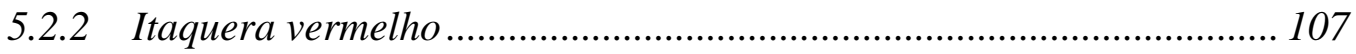

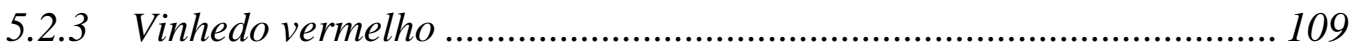

5.2.4 Comparação entre os produtos de separações em líquidos densos..... 111

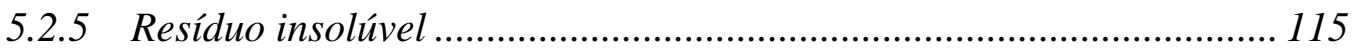

5.2.6 Sumário dos resultados ................................................................... 117

6 CARACTERIZAÇÃO MICROESTRUTURAL................................. 120

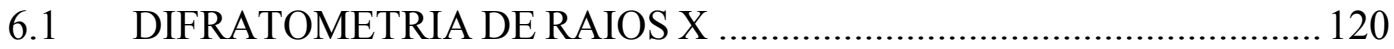

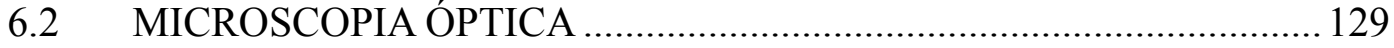

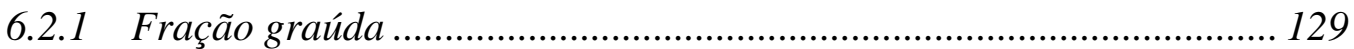

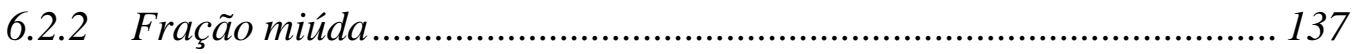

7 CARACTERIZAÇÃO DAS PROPRIEDADES FÍSICAS............... 151

7.1 DETERMINAÇOES DE MASSA ESPECÍFICA ...................................... 151

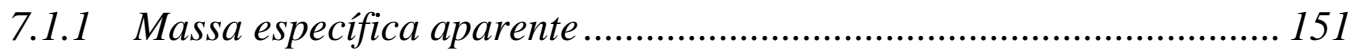

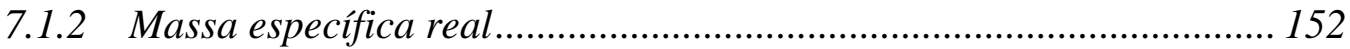

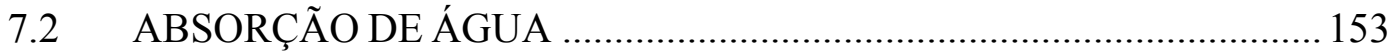

7.3 SUMÁRIO DAS PROPRIEDADES FÍSICAS ….................................... 154

8 CONSIDERAÇÕES FINAIS........................................................... 156

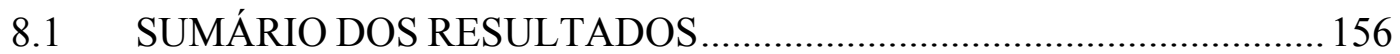

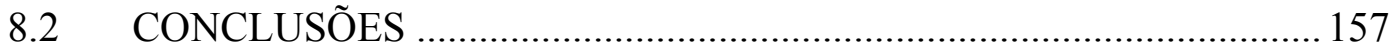

REFERÊNCIAS BIBLIOGRÁFICAS .......................................................159

LISTA DE TABELAS

LISTA DE FIGURAS

LISTA DE ABREVIAÇÕES

APÊNDICE - TABELAS DE COMPOSIÇÃO QUÍMICA 


\section{LISTA DE TABELAS}

página

Tabela 2.1 - Estimativa da geração de RCD (JOHN, 2000), modificada .................... 6

Tabela 2.2 - Parcela de RCD nos RSU e a taxa de geração (apud PINTO, 1999)..... 7

Tabela 2.3 - Perdas de material em construções convencionais (apud PINTO, 1999)9

Tabela 2.4 - Técnicas de identificação de espécies minerais (modificado de

SANT'AGOSTINHO; KAHN, 1997)

Tabela 2.5 - Descrição de alguns equipamentos industriais utilizados nas operações unitárias (SANT`AGOSTINO; KAHN, 1997 adaptado; KELLY;

SPOTTISWOOD, 1982). 39

Tabela 2.6 - Operações unitárias e equipamentos encontrados em algumas usinas fixas nacionais de reciclagem da fração mineral do RCD (ÂNGULO et al., 2005, modificado)

Tabela 2.7 - Operações unitárias e equipamentos de algumas usinas fixas de reciclagem da fração mineral do RCD (ÂNGULO, et al, 2005 - modificado) .. 54

Tabela 4.1 - Análise granuloquímica do produto IT-C - TQ .................................... 87

Tabela 4.2 - Análise granuloquímica do produto IT-C - PB .................................... 87

Tabela 4.3 - Análise granuloquímica do produto IT-V - TQ .....................................89

Tabela 4.4 - Análise granuloquímica do produto IT-V - PB ..................................... 89

Tabela 4.5 - Análise granuloquímica do produto VI-V - TQ .................................... 91

Tabela 4.6 - Análise granuloquímica do produto VI-V - PB .................................... 91

Tabela 4.7 - Análise granuloquímica da composição FBP+PB do RCD IT-C .......... 93

Tabela 4.8 - Análise granuloquímica da composição FBP+PB do RCD IT-V ......... 93

Tabela 4.9 - Análise granuloquímica da composição FBP+PB do RCD VI-V ......... 94

Tabela 4.10 - Teores de íons solúveis (ÂNGULO, 2005) ......................................... 99

Tabela 5.1 - Distribuição de massa do agregado IT-C nos intervalos de densidade

Tabela 5.2 - Distribuição de massa do agregado IT-V nos intervalos de densidade 
Tabela 5.3 - Distribuição de massa do agregado VI-V nos intervalos de densidade

Tabela 5.4 - Análise química dos produtos de separação por líquidos densos: IT-C 106

Tabela 5.5 - Análise química dos produtos de separação por líquidos densos: IT-V 108

Tabela 5.6 - Análise química dos produtos de separação por líquidos densos: VI-V

Tabela 5.7 - Teores de resíduo insolúvel e de aglomerantes; IT-C 116

Tabela 5.8 - Teores de resíduo insolúvel e de aglomerantes; IT-V 116

Tabela 5.9 - Teores de resíduo insolúvel e de aglomerantes; VI-V 116

Tabela 6.1 - Composição mineralógica (em porcentagem) das frações graúda e miúda. 120

Tabela 6.2 - Composição mineralógica dos produtos de separações densitárias para as frações graúda e miúda ................................................................................ 123

Tabela 7.1 - Massa específica aparente para os produtos graúdos ......................... 151

Tabela 7.2 - Massa específica aparente para os produtos miúdos........................... 151

Tabela 7.3 - Massa específica determinada por intrusão de gás hélio ..................... 152

Tabela 7.4 - Absorção de água para os produtos graúdos....................................... 153

Tabela 7.5 - Absorção de água para os produtos miúdos ......................................... 153 


\section{LISTA DE FIGURAS}

página

Figura 2.1 - Origem dos RCD nos EUA (YOST, 1998) ........................................... 8

Figura 2.2 - Origem dos RCD em Hong Kong (Hong Kong, 1993) ........................... 8

Figura 2.3 - Composição do RCD gerado na Holanda (BOSSINK; BROWERS, 1996)

Figura 2.4 - Composição do RCD gerado no Japão (HONG KONG POLYTECHNIC,

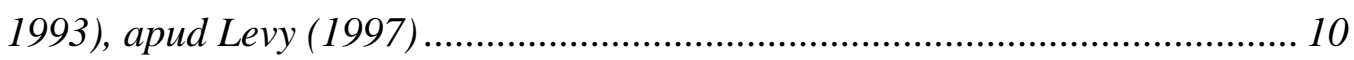

Figura 2.5 - Cerâmica vermelha junto com concreto.............................................. 11

Figura 2.6 - Compósito de isolamento cimento - madeira .......................................... 11

Figura 2.7 - Composição dos agregados de RCD reciclados para as diferentes caçambas avaliadas - avaliação por catação (ÂNGULO, 2000) ....................... 11

Figura 2.8 - RCD mineral cinza (a) e vermelho (b) da usina de Itaquera ................. 13

Figura 2.9 - Deposição ilegal na cidade de São Paulo .............................................. 14

Figura 2.10 - Fotografia do aterro de Itaquera a partir de agregados reciclados de

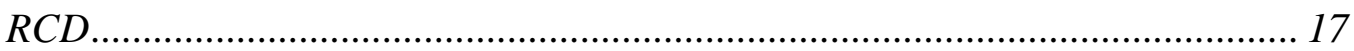

Figura 2.11 - Fotografia de um microscópio estereoscópico...................................... 28

Figura 2.12 - Microscópio de luz refletida …............................................................ 29

Figura 2.13 - Microscópio de luz transmitida ........................................................... 29

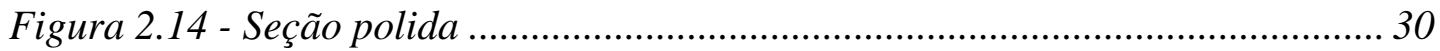

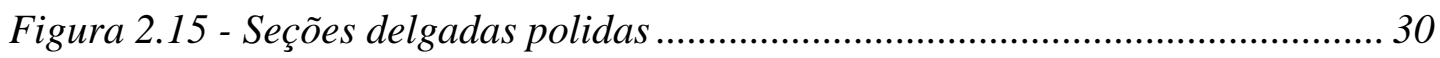

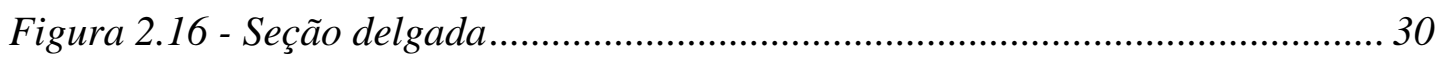

Figura 2.17 - Frantz isodinâmico ......................................................................... 34

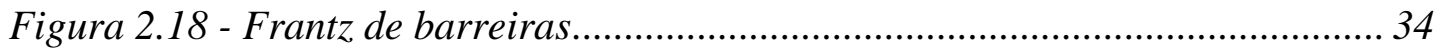

Figura 2.19 - Equipamento de separação magnética de alta intensidade via úmida

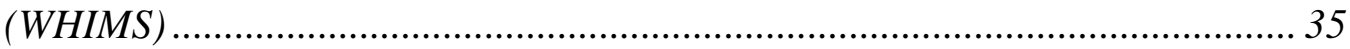

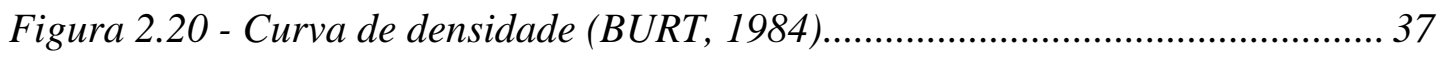

Figura 2.21 - Equipamentos de possível uso em RCD (JUNGMANN; QUINDT, 1999, JONES, 1987, modificado). 
Figura 2.22 - Classificação do RCD em mineral e não-mineral através de câmera digital

Figura 2.23 - Separação da fração não-mineral do RCD na alimentação de usinas de reciclagem da Holanda Fonte: Hendriks, 2000; Kowalczyk et al., 2002;

Thole, 2002

Figura 2.24 - Fração metálica obtida por separação magnética (a) e catação (b) em

Salzburg. Fonte: Sérgio C. Ângulo . 43

Figura 2.25 - Esquema do funcionamento dos classificadores pneumáticos utilizados na reciclagem da fração mineral do RCD (HENDRIKS, 2000)........................ 44

Figura 2.26 - Equipamento de separação óptica (Scan\&Sort) ................................. 46

Figura 2.27 - Fração não mineral (lignita, isopor, madeira) separada por jigagem

(Salzburg, Áustria). Fonte: Sérgio C. Ângulo 47

Figura 2.28 - Produtos de RCD reciclado da usina de Salzburg: (a) agregado graúdo (4-16 mm), (b) areia. Fonte: Sérgio C. Ângulo.... 48

Figura 2.29 - Lama resultante da jigagem de RCD da usina de Salzburg. Fonte:

Sérgio C. Ângulo. 48

Figura 2.30 - Vista frontal (a) e lateral (b) do leito pulsante do jigue (Salzburg,

Áustria). Fonte: Sérgio C. Ângulo. 49

Figura 2.31 - Desenho esquemático sobre o funcionamento do "Alljig” (Fonte:

www.allmineral.com, modificada) 50

Figura 2.32 - Desenho esquemático sobre o funcionamento do "Allflux” (Fonte: www.allmineral.com, modificada) 50

Figura 2.33 - Desenho esquemático sobre o funcionamento do “Allair” (Fonte: www.allmineral.com, modificada)

Figura 2.34 - Fluxograma de uma usina de reciclagem da fração mineral do RCD na Alemanha (MULLER, 2003 - adaptado). 55

Figura 2.35 - Fluxograma do usina dos agregados de RCD reciclados com utilização de jigue (JUNGMANN, 1997; JUNGMANN; QUINDT, 1999) 56

Figura 2.36 - Pilhas de RCD na usina de Itaquera (a) RCD cinza, (b) RCD vermelho

Figura 2.37 - Seleção manual do RCD na usina de reciclagem de Itaquera; (a) antes e (b) após a britagem 58 
Figura 2.38 - Britador de impacto da usina de Itaquera......................................... 58

Figura 2.39 - Separação magnética na usina de Itaquera (São Paulo) ..................... 59

Figura 2.40 - Etapa de peneiramento na usina de Itaquera.....................................5 59

Figura 2.41 - Fluxograma da usina de reciclagem da fração mineral do RCD de

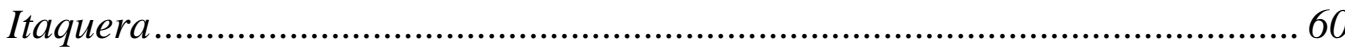

Figura 2.42 - Visão geral da usina de Vinhedo ......................................................... 61

Figura 2.43 - Visão geral dos RCD processados na usina de Vinhedo..................... 61

Figura 2.44 - Britador de mandíbulas da usina de vinhedo......................................62

Figura 2.45 - (a) peneira inclinada (b) produto britado e classificado ..................... 62

Figura 2.46 - Fluxograma da usina de reciclagem da fração mineral do RCD de

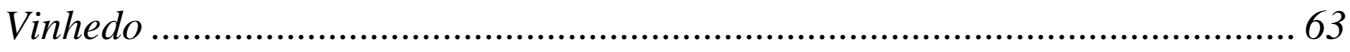

Figura 3.1 - Esquema de procedimento experimental .............................................6 66

Figura 3.2 - Procedimento para homogeneização em pilha alongada ...................... 67

Figura 3.3 - Pilha de homogeneização na usina de Itaquera (produto IT-V)........... 68

Figura 3.4 - Re-homogeneização e amostragem do produto VI-V ............................6 69

Figura 3.5 - Peneirador mecânico para peneiras quadradas de 50 × $50 \mathrm{~cm}$............. 70

Figura 3.6 - Peneirador mecânico para peneiras circulares de $20 \mathrm{~cm}$ de diâmetro. 70

Figura 3.7 - Peneiramento a úmido: (a) fundo adaptado e (b) recuperação da água

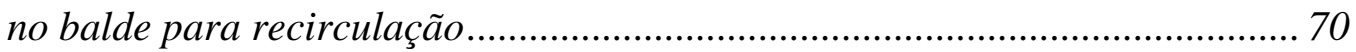

Figura 3.8 - Britador de mandíbulas, escala de laboratório...................................... 71

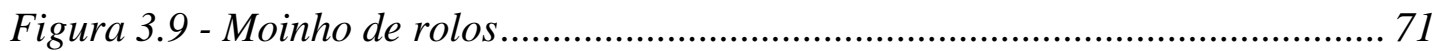

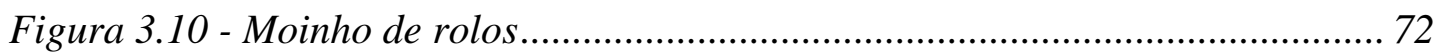

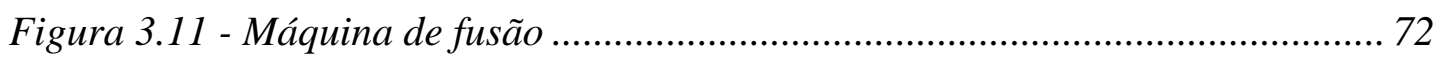

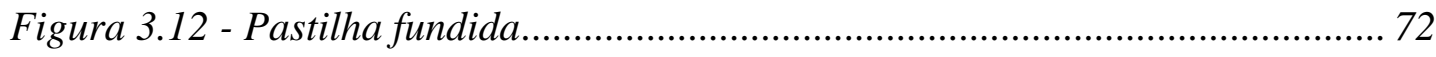

Figura 3.13 - Separação seqüencial em líquidos densos para se estabelecer uma curva de separabilidade por densidade (BURT, 1984, modificado) ................. 74

Figura 3.14 - Acessórios utilizados para separação em cloreto de zinco.................. 75

Figura 3.15 - Desenho esquemático que ilustra separação por líquidos densos

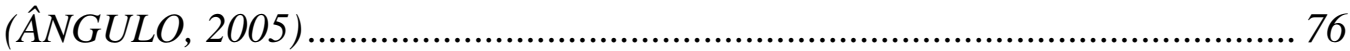

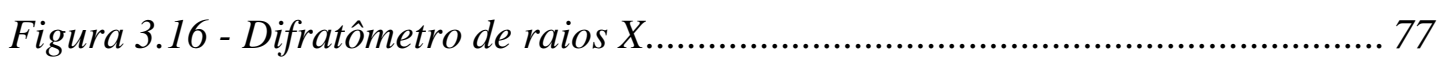

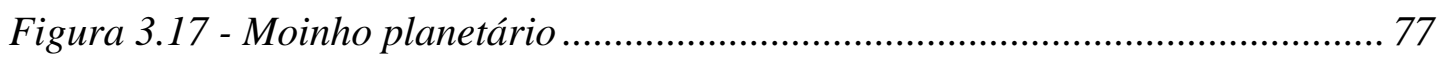

Figura 3.18 - Amostra prensada para DRX .......................................................... 77 
Figura 3.19 - Picnômetro com intrusão de gás hélio .

Figura 3.20 - (a) saturação dos agregados graúdos de RCD reciclados; (b) balança hidrostática para determinação da massa submersa 80

Figura 3.21 - (a) secagem doa agregados miúdos com ventilador; (b) determinação da condição de SSS .....

Figura 3.22 - (a) bomba de vácuo acoplada ao frasco de Chapman (a) e presença de ar incorporado nos agregados miúdos de RCD reciclados (b). 81

Figura 4.1 - Distribuições granulométricas acumuladas no passante dos produtos “Tal Qual”.

Figura 4.2 - Distribuições granulométricas acumuladas no passante dos PB. 84

Figura 4.3 - Comparação entre as distribuições granulométricas acumuladas no

passante para os produtos TQ e PB das três amostras estudadas 85

Figura 4.4 - Curva de distribuição granulométrica resultante da composição dos produtos FBP e PB para as amostras estudadas.... 86

Figura 4.5 - Teores dos óxidos $\mathrm{SiO}_{2}, \mathrm{Al}_{2} \mathrm{O}_{3}, \mathrm{CaO}$ e perda ao fogo por fração granulométrica dos produtos TQ e PB do agregado de $R C D$ reciclado IT-C .. 88 Figura 4.6 -Teores dos óxidos $\mathrm{SiO}_{2}, \mathrm{Al}_{2} \mathrm{O}_{3}, \mathrm{CaO}$ e perda ao fogo por fração granulométrica para os produtos TQ e PB do agregado de $R C D$ reciclado $I T-V$

Figura 4.7 - Teores dos óxidos $\mathrm{SiO}_{2}, \mathrm{Al}_{2} \mathrm{O}_{3}, \mathrm{CaO}$ e perda ao fogo por fração granulométrica para os produtos TQ e PB do agregado de RCD reciclado VI-V

Figura 4.8 - Teores dos óxidos $\mathrm{SiO}_{2}, \mathrm{Al}_{2} \mathrm{O}_{3}, \mathrm{CaO}$ e perda ao fogo por fração granulométrica dos produtos $F B P+P B$ dos agregados de $R C D$ reciclados de IT-C, IT-V e VI-V 95

Figura 4.9 - Relação entre os teores de sílica (a), alumina e óxido de cálcio (b) com a perda ao fogo 96

Figura 4.10 - Relação entre os teores de sílica, alumina e + óxido de cálcio com a perda ao fogo 97

Figura 4.11 - Correlação entre os teores de $\mathrm{SiO}_{2}+\mathrm{Al}_{2} \mathrm{O}_{3}+\mathrm{Fe}_{2} \mathrm{O}_{3}$ e $\mathrm{CaO}+\mathrm{PF}$ (rochas naturais + cerâmicas versus argilominerais + aglomerantes) 98 
Figura 4.12 - Relação entre os teores de sílica e óxido de cálcio para os três agregados estudados

Figura 5.1 - Curvas de separabilidade por densidade de IT-C com valores em massa acumulados para o afundado. 101

Figura 5.2 - Curvas de separabilidade por densidade de IT-V com valores em massa acumulados para o afundado. 102

Figura 5.3 - Curvas de separabilidade por densidade de VI-V com valores em massa acumulados para o afundado.

Figura 5.4 - Distribuição dos produtos nas densidades. 104

Figura 5.5 - Comparação entre teores dos principais óxidos para os produtos de separação em líquidos densos: IT-C.

Figura 5.6 - Comparação entre teores dos principais óxidos para os produtos de separação em líquidos densos: IT-V.

Figura 5.7 - Comparação entre teores dos principais óxidos para os para os produtos de separação em líquidos densos: VI-V.

Figura 5.8 - Comparação entre teores de sílica por faixa densitária

Figura 5.9 - Comparação entre teores de alumina por faixa densitária

Figura 5.10 - Comparação entre teores de CaO por faixa densitária

Figura 5.11 - Comparação entre teores de perda ao fogo por faixa densitária

Figura 5.12 -Teores médios de RI por intervalo de densidade

Figura 5.13 - Teores médios de aglomerantes por intervalo de densidade

Figura 5.14 - Correlação entre os teores de $\mathrm{SiO}_{2}$ e $\mathrm{Ca}+\mathrm{Al}_{2} \mathrm{O}_{3}$ (a) e entre os teores de $\mathrm{SiO}_{2}$ e os teores estimados de aglomerantes (b) para os produtos de separação em líquidos densos

Figura 5.15 - Correlação entre os teores estimados de aglomerantes e a perda ao fogo nos produtos de separação em líquidos densos 118

Figura 5.16 - Teores estimados de aglomerantes para as diferentes classes e origem de RCD em função da granulometria e densidade 119

Figura 5.17 - Teores de perda ao fogo para diferentes classes e origem de RCD em função da granulometria e densidade.....

Figura 6.1 - Comparação entre composições mineralógicas das frações graúda, miúda e finos $(<0,15 \mathrm{~mm})$. 
Figura 6.2 - Difratogramas comparativos referentes às frações granulométricas da amostra Itaquera Cinza

Figura 6.3 - Difratogramas comparativos referentes às frações granulométricas da amostra Itaquera Vermelho

Figura 6.4 - Difratogramas comparativos referentes às frações granulométricas da amostra Vinhedo Vermelho.

Figura 6.5 - Comparação entre composições mineralógicas dos produtos de separações densitárias

Figura 6.6 - Difratogramas comparativos referentes aos produtos de separações densitárias da amostra Itaquera Cinza - fração graúda (a) e miúda (b) ........ 125

Figura 6.7 - Difratogramas comparativos referentes aos produtos de separações densitárias da amostra Itaquera Vermelho - fração graúda (a) e miúda (b).. 126

Figura 6.8 - Difratogramas comparativos referentes aos produtos de separações densitárias da amostra Vinhedo Vermelho - fração graúda (a) e miúda (b) .. 127

Figura 6.9 - Partículas não minerais presentes em (a) IT-V $d<1,7-12,7+9,5$ mm e

(b) $V I-V-4,8+2,4 \mathrm{~mm} d<1,7$ (aumento de $5 \mathrm{x}$ )

Figura 6.10 - Seções polidas dos produtos do intervalo de densidade entre 1,9 e 2,2 $\mathrm{g} / \mathrm{cm}^{3}$ 130

Figura 6.11 - Seções polidas dos produtos do intervalo de densidade entre 1,9-2,2 $\mathrm{g} / \mathrm{cm}^{3}$ sob luz incidente nas faixas de comprimento de onda do visível (a) e ultravioleta (b)

Figura 6.12 - Seções polidas dos produtos do intervalo de densidade entre 2,2-2,5 $\mathrm{g} / \mathrm{cm}^{3}$

Figura 6.13 - Seções polidas dos produtos do intervalo de densidade entre 2,2-2,5 $\mathrm{g} / \mathrm{cm}^{3}$ sob luz incidente nas faixas de comprimento de onda do visível (a) e ultravioleta (b)

Figura 6.14 - Seções polidas dos produtos do intervalo de densidade entre 2,2-2,5 $\mathrm{g} / \mathrm{cm}^{3}$

Figura 6.15 - Seções polidas dos produtos do intervalo de densidade superior a 2,5 $\mathrm{g} / \mathrm{cm}^{3}$ sob luz incidente nas faixas de comprimento de onda do visível (a) $e$ ultravioleta (b) 
Figura 6.16 - Fotografias das seções delgadas polidas das frações miúdas dos produtos de densidade entre 1,9-2,2 $\mathrm{g} / \mathrm{cm}^{3}$ de IT-C, IT-V e VI-V.

Figura 6.17 - Microfotografias da fração miúda dos produtos de densidade 1,9-2,2 $\mathrm{g} / \mathrm{cm}^{3}$ de IT-C

Figura 6.18 - Microfotografias da fração miúda dos produtos de densidade 1,9-2,2

$\mathrm{g} / \mathrm{cm}^{3}$ de $I T-V$ 140

Figura 6.19 - Microfotografias da fração miúda dos produtos de densidade 1,9-2,2 $\mathrm{g} / \mathrm{cm}^{3}$ de $V I-V$

Figura 6.20 - Fotografias das seções delgadas polidas das frações miúdas dos produtos de densidade entre 2,2-2,5 $\mathrm{g} / \mathrm{cm}^{3}$ de IT-C, IT-V e VI-V.

Figura 6.21 - Microfotografias da fração miúda dos produtos de densidade 2,2-2,5 $\mathrm{g} / \mathrm{cm}^{3}$ de IT-C. 144

Figura 6.22 - Microfotografias da fração miúda dos produtos de densidade 2,2-2,5 $\mathrm{g} / \mathrm{cm}^{3}$ de $I T-V$ 145

Figura 6.23 - Microfotografias da fração miúda dos produtos de densidade 2,2-2,5 $\mathrm{g} / \mathrm{cm}^{3}$ de $\mathrm{VI}-\mathrm{V}$ 146

Figura 6.24 - Fotografias das seções delgadas polidas das frações miúdas dos produtos de densidade superior a 2,5 $\mathrm{g} / \mathrm{cm}^{3}$ de IT-C, IT-V e VI-V. 147

Figura 6.25 - Microfotografias da fração miúda dos produtos de densidade superior a $2,5 \mathrm{~g} / \mathrm{cm}^{3}$ de IT-C. 148

Figura 6.26 - Microfotografias da fração miúda dos produtos de densidade superior a $2,5 \mathrm{~g} / \mathrm{cm}^{3}$ de IT-V........

Figura 6.27 - Microfotografias da fração miúda dos produtos de densidade superior a $2,5 \mathrm{~g} / \mathrm{cm}^{3}$ de $V I-V$.

Figura 7.1 - Resultados de massa específica aparente dos produtos em função da fração retida em peneira, natureza ou origem do RCD e da separação por líquidos densos

Figura 7.2 - Resultados de absorção de água (b) dos produtos em função da fração retida em peneira, natureza ou origem do RCD e da separação por líquidos densos. 


\section{LISTA DE SIGLAS E ABREVIAÇÕES}

A - absorção de água; determinada em porcentagem

AAS - absorção atômica

ABNT - Associação Brasileira de Normas Técnicas

$\mathrm{AC}$ - antes da cominuição

AP - abatedor de poeira

Argilm.; AM - argilominerais

B.S.C.J. - Building Contractors Society of Japan

Carb. - carbonatos

$\mathrm{CD}$ - construction and demolition

CDW - construction and demolition waste; termo em inglês para RCD

CETESB - Companhia de Tecnologia de Saneamento Ambiental

CONAMA - Conselho Nacional do Meio Ambiente

DIN - Deutsche Institut für Normung

DRX - difração de raios X

EDS - espectrometria por dispersão de enrgia

FBP - "finos de britagem primária" - parcela da amostra TQ de granulometria inferior a $25,4 \mathrm{~mm}$

Feld. - feldspatos

Felds.K - feldspato potássico

FRX - Fluorescência de raios X

Gib. - gibsita

$\mathrm{HCl}$ - Ácido Clorídrico

IBGE - Instituto Brasileiro de Geografia e Estatística

IC - cromatografia iônica

ICDD - International Centre for Diffraction Data

ICP-MS - espectrometria de massa por plasma de acoplamento indutivo

ICP-OES - espectrometria de emissão por plasma de acoplamento indutivo

INNA - análise de ativação neurônica instrumental

IT-C - "Itaquera cinza"; fração mineral de RCD do tipo cinza proveniente da usina de Itaquera

IT-V - "Itaquera vermelho"; fração mineral de RCD do tipo vermelho proveniente da usina de Itaquera

$\mathrm{L}$ - litro ou $\mathrm{dm}^{3}$

LST, LTM, SPT - soluções de sais de tungstênio

MEA - massa específica aparente $\left(\mathrm{kg} / \mathrm{dm}^{3}\right.$ ou $\left.\mathrm{g} / \mathrm{cm}^{3}\right)$

NBR - Norma Brasileira 
nd - não detectado

PB - "produto britado" - amostras de RCD após britagem secundária em laboratório

PC - após cominuição

$\mathrm{PF}$ - perda ao fogo a $1.050^{\circ} \mathrm{C}$

pp - possível presença

Qz - quartzo

RCD - Resíduo (s) de Construção e Demolição

RILEM - International Union of Laboratories and Experts in Construction Materials, Systems and Structures

RMSP - região metropolitana de São Paulo

RSU - resíduos sólidos urbanos.

SIERESP - Sindicato das Empresas Removedoras do Estado de São Paulo

SISNAMA - Sistema Nacional do Meio Ambiente

SSS - superfície saturada seca - condição em que o material não apresenta umidade superficial

TBE - tetrabromoetano

TC - transportador de correia

TQ - "tal qual"- material amostrado nas usinas de reciclagem após britagem primária

VI-V - "Vinhedo vermelho"; fração mineral de RCD do tipo vermelho proveniente da usina de Vinhedo.

WDS - espectrometria por dispersão de comprimento de onda

WHIMS - wet high intensity magnetic separator 


\section{RECICLAGEM DE RESÍDUOS}

\section{DE CONSTRUÇÃO E \\ DEMOLIÇÃO}

CARINA ULSEN 


\section{INTRODUÇÃo}

Os resíduos da construção e demolição $(\mathrm{RCD})^{1}$ representam uma grande parcela dos resíduos sólidos urbanos, sendo que a geração anual média é de $500 \mathrm{~kg} / \mathrm{hab}$., em cidades brasileiras de médio a grande porte, dos quais cerca de $50 \%$ são gerados por atividades de construções, o que pode ser atribuído à alta intensidade de novas construções e pouca atividade de demolição, bem como às elevadas taxas de desperdício de materiais nos canteiros de obras.

A motivação principal do trabalho reside no fato de que uma grande parcela dos resíduos (cerca de 90\%) é de origem mineral e pode, portanto, ser reciclada através de processos de beneficiamento mineral. Somado a isso, a reciclagem atrelada a um sistema formal de gerenciamento de resíduos é uma ferramenta eficiente para se obter a sustentabilidade no setor de construção civil, diminuindo o consumo de bens minerais não renováveis, bem como as áreas de deposição destes.

No cenário atual, a deposição dos RCD, tanto no Brasil como em países de economia desenvolvida, está intrinsecamente ligada à ilegalidade - é comum deparar-se á grandes quantidades de "entulhos" depositados por ruas de cidades de pequeno a grande porte. O transporte destes para locais inapropriados não soluciona o problema e ainda implica em impactos ambientais e sociais, além de todo o custo associado.

Assim como a reciclagem de embalagens PET, vidro, plástico, alumínio e papel têm se intensificado, a reciclagem dos resíduos de construção e demolição é da mesma forma imprescindível dentro de um contexto de resgate do meio ambiente. Decretos recentes do Conselho Nacional do Meio Ambiente vieram a corroborar com as iniciativas de reciclagem de $\mathrm{RCD}$, à medida que proíbe a deposição destes em aterros sanitários.

Atualmente grande parte dos agregados de RCD reciclados, tanto no Brasil como no exterior, é utilizada em atividades de pavimentação em função do bom desempenho técnico e baixas exigências de qualidade, prática esta conhecida como "reciclagem

\footnotetext{
${ }^{1}$ Utiliza-se a sigla RCD para denominação no singular ou plural.
} 
de baixo valor ou downcycling”, que ainda assim não é capaz de absorver todo o volume de resíduos gerados. Desta forma, há uma crescente necessidade pela busca de novos mercados, tendo a diversificação de produtos como ponto de extrema importância.

Para tal propósito a caracterização tecnológica do RCD é fundamental para $\mathrm{o}$ estabelecimento de um método adequado de usina segundo técnicas de beneficiamento mineral. Desta forma, esta dissertação se insere em um programa mais amplo de estudos de RCD visando avaliar as suas características físicas, químicas e microestruturais e possíveis alternativas de aplicações, bem como o estabelecimento de procedimentos padronizados de caracterização.

\subsection{GRUPO DE PESQUISA}

Os estudos de resíduos de construção e demolição ora apresentados estão inseridos em um programa multidisciplinar conduzido pelos Departamentos de Engenharia de Construção Civil e de Engenharia de Minas e de Petróleo da Escola Politécnica da USP, dentro do qual cada pesquisador envolvido aborda a questão por uma face, de modo que a pesquisa caminha paralelamente com o desenvolvimento de vários tópicos complementares.

As atividades iniciaram-se em 2002, com o início do trabalho do então aluno de doutorado da Engenharia Civil Sérgio C. Ângulo que iniciava o programa de doutorado através do projeto Verde Amarelo - Finep Habitare (Convênio 23.01.0673.00), concluído no final de 2005. Paralelamente, também em 2002, a aluna de graduação em Engenharia de Minas, Carina Ulsen, iniciou seu trabalho de Iniciação Científica com apoio da FAPESP (02/00849-1), o qual se estendeu por período de 24 meses, culminando com o trabalho de formatura. Como a pesquisa ainda contava com certos questionamentos, o trabalho teve seqüência no programa de mestrado da mesma.

Todo o tema abordado nesta dissertação, bem como as atividades experimentais, foram desenvolvidos pela mestranda, paralelamente a outras investigações realizadas por outros alunos, algumas das quais aqui referenciadas. 
O trabalho apresentado tem despertado grande interesse nos estudiosos do assunto, como também em empresas do ramo, e tem sido atualmente apoiado por outras instituições, como o CETEM, Petrobrás e prefeitura de Macaé. Foi apresentado pela primeira vez no X Simpósio Internacional de Iniciação Científica da USP (SIICUSP), em 2002, no qual recebeu menção honrosa dentre os melhores trabalhos do ano; foi também reconhecido como o melhor dentre os Trabalhos de Formatura dos alunos do ano de 2004 recebendo o prêmio "Antônio Ermínio de Moraes" no ano seguinte. Em um contexto mais amplo, o trabalho gerou publicações de cunho tanto nacional como internacional, tendo inclusive sido premiado ${ }^{2}$ pela Prefeitura da cidade de São Paulo com o projeto intitulado "Projeto Casulo leva escola e centro cultural à favela" que previa a comercialização de areia de RCD reciclada com finalidade sócio-ambiental.

\subsection{OBJETIVOS}

Todo o tema aqui abordado baseia-se na caracterização dos $\mathrm{RCD}^{3}$ provenientes de duas diferentes usinas ${ }^{4}$ de reciclagem, tendo por objetivo central a determinação da composição química e mineralógica, das propriedades físicas e microestruturais do RCD estudado.

Nesse sentido fez parte do escopo do trabalho:

- Avaliar a composição química de cada amostra por fração granulométrica.

- Separar os RCD em intervalos de densidade para posterior determinação de composição química e mineralógica e suas propriedades físicas por intervalo considerado.

- Observações sistemáticas em microscópio óptico para verificação do teor de aglomerantes associados aos grãos de minerais e comprovação das hipóteses sugeridas pelos resultados de análises químicas.

\footnotetext{
${ }^{2}$ Premiação recebida pelos pesquisadores Sérgio C. Ângulo, Leonardo Miranda e Sílvia de Souza Selmo, dentre outros, em um programa de atividades paralelas de pesquisa sobre o tema abordado.

${ }^{3} \mathrm{O}$ material estudado será designado por RCD e não agregados de RCD, como adotado por alguns autores, visto que o material amostrado encontrava-se apenas britado sem nenhuma classificação granulométrica.

${ }^{4}$ Designam-se usinas de reciclagem as unidades de processamento da fração mineral de RCD.
} 


\subsection{ESTRUTURA DA DISSERTAÇÃO}

\subsubsection{Capítulo 1 - Introdução}

O capítulo apresenta o trabalho desenvolvido e situa o leitor no contexto geral de desenvolvimento da pesquisa em questão.

\subsubsection{Capítulo 2 - Revisão Bibliográfica}

Este capítulo tem por finalidade apresentar ao leitor o contexto nacional e internacional de reciclagem de resíduos de construção e demolição, a sua origem, composição e gerenciamento bem como as possíveis aplicações. Aborda ainda uma revisão da caracterização tecnológica e dos métodos de beneficiamento empregados na reciclagem de $\mathrm{RCD}$.

\subsubsection{Capítulo 3 - Procedimento experimental}

O capítulo 3 apresenta detalhadamente todas as etapas do procedimento experimental estabelecido.

\subsubsection{Capítulos 4 a 7 - Resultados e discussões}

Os Capítulos de 4 a 7 exprimem os resultados obtidos, sendo :

- Capítulo 4 - Análise granuloquímica: expressa os resultados das análises químicas para cada intervalo granulométrico considerado.

- Capítulo 5 - Separação em líquidos densos: apresenta uma discussão sobre os resultados da separação em líquidos densos de cada amostra e a composição química de cada produto.

- Capítulo 6 - Caracterização mineralógica e microestrutural: apresenta a distribuição de fases entre os produtos de diferentes densidades e discute as fotografias resultantes de observações sistemáticas ao microscópio óptico.

- Capítulo 7 - Caracterização física: discute os resultados de massa específica aparente e absorção de água por faixa de densidade dos produtos.

\subsubsection{Capítulo 8 - Considerações finais}

O capítulo encerra a dissertação retomando os principais aspectos abordados, suas conclusões e apresentando uma proposição para estudos futuros. 


\section{REVISÃO BIBLIOGRÁFICA}

\subsection{GESTÃO DE RESÍDUOS}

\subsubsection{Resíduos de construção e demolição}

Resíduo de Construção e Demolição é o termo aplicado a resíduos provenientes de atividades de construção, reformas ou demolições (ANGULO, 2000; FERRAZ et al., 2001; EC, 2000; WILSON, 1996; SCHULTMANN; RENTZ, 2000), embora alguns autores prefiram o termo entulho.

Levy (1997a) define entulho de construção civil como a parcela mineral dos resíduos provenientes de construção e demolição, não considera atividades de obras engenharia civil de grande porte; já a Hong Kong Polytechnic (1993) define entulho de forma mais abrangente, englobando as obras de construção civil. Na literatura várias referências definem resíduos de construção e demolição, como Bossink; Browers (1996), Pera (1996), Collins (1997), Harder; Freeman (1997) E Zordan (1997).

Para Biocycle (1990), apud Zordan (1997), RCD são "resíduos sólidos não contaminados, provenientes de construção, reforma, reparos e demolição de estruturas e estradas, e resíduos sólidos não contaminados de vegetação, resultantes de limpeza e escavação de solos. Como resíduos, incluem-se blocos, concreto e outros materiais de alvenaria, solo, rocha, madeira, forros, argamassa, gesso, encanamentos, telhas, pavimento asfáltico, vidros, plásticos que não camuflem outros resíduos, fiação elétrica e equipamentos que não contenham líquidos perigosos e metais que estiverem num desses itens acima".

No presente trabalho a denominação RCD referir-se-á a qualquer tipo de resíduos provenientes de atividades de construção civil e demolições, incluindo-se as fases mineral e não mineral.

\subsubsection{Geração de RCD}

O consumo de agregados no Brasil é da ordem de $380 \times 10^{6}$ t/ano (ANGULO et al., 2002a); a reciclagem da fração mineral dos agregados de RCD reciclados atenderia 
apenas $16,2 \%$ desse mercado e poderia ser utilizado como fonte alternativa de matéria para o setor de produção de agregados naturais, podendo essa reciclagem ser incorporada pelo setor, sem inviabiliza-lo.

A quantificação do volume de RCD gerados em cidades brasileiras é dificultada pela carência de informações, entretanto, estima-se que a geração média no Brasil seja de $500 \mathrm{~kg} /$ ano.hab., totalizando 68,5 milhões de t/ano para a população brasileira ${ }^{5}$ (ANGULO et al., 2002a); a Região Metropolitana de São Paulo (RMSP) contribui com $8 \%$ desse $\operatorname{total}^{6}\left(5,5 \times 10^{6}\right.$ t/ano) (ANGULO et al., 2002a). A geração de RCD nos países da Comunidade Européia é estimada entre 500 e 1.000 kg/ano.hab.) (PERA, 1996; IVBR, 1995).

Na Tabela 2.1 é mostrada uma estimativa da geração dos RCD para alguns países, onde se observa que a geração de RCD per capita é maior na Europa e Japão do que no Brasil, fato essencialmente relacionado ao elevado número de novas construções. Adicionalmente, verifica-se que uma estimativa muito imprecisa, com diferenças significativas nas médias.

Tabela 2.1 - Estimativa da geração de RCD (JOHN, 2000), modificada

\begin{tabular}{ccc}
\hline \hline Países & Quantidade (kg/hab) & Período considerado \\
\hline \hline Suécia & $140-680$ & 1996 \\
Holanda & $820-1300$ & --- \\
EUA & $460-590$ & 1996 \\
Inglaterra & $880-1120$ & $1995-1996$ \\
Bélgica & $730-3360$ & $1990-1992$ \\
Dinamarca & $440-2010$ & --- \\
Itália & $600-700$ & --- \\
Alemanha & $960-3660$ & $1994-1996$ \\
Japão & 780 & 1995 \\
Portugal & 320 & anual (exclui solos) \\
Brasil & $230-660$ & anual (algumas cidades) \\
\hline \hline
\end{tabular}

\footnotetext{
${ }_{6}^{5}$ Segundo IBGE a população urbana é de 137 milhões de pessoas

${ }^{6}$ Considerando-se 17 milhões de pessoas
} 
O volume de RCD gerado representa de 13 a 67\% (JOHN, 2000; HENDRIKS, 2000) em massa de todo o resíduo sólido urbano gerado (RSU), no Brasil esse valor é estimado em 50\% (PINTO, 1999), sendo que a metade ou mais do RCD é proveniente de atividades de construção (SINDUSCON-SP, 2005), assim como para a cidade de Hong Kong (POON et al., 2001); entretanto na Europa a situação se inverte, de modo que os resíduos provenientes de demolições ultrapassam $50 \%$ do total de RCD (LAURITZEN, 1994; PERA, 1996).

A Tabela 2.2 ilustra a participação em massa dos RCD nos Resíduos Sólidos Urbanos (RSU) e a taxa de geração de RCD.

Tabela 2.2 - Parcela de RCD nos RSU e a taxa de geração (apud PINTO, 1999)

\begin{tabular}{|c|c|c|}
\hline Local & RCD (\% massa do RSU) & RCD (t/hab/ano) \\
\hline Belo Horizonte/MG ${ }^{1}$ & 54 & 0,34 \\
\hline Campinas/SP ${ }^{2}$ & 64 & 0,62 \\
\hline Jundiaí/SP & 62 & 0,76 \\
\hline Ribeirão Preto/SP & 70 & 0,71 \\
\hline Salvador/BA ${ }^{3}$ & 41 & 0,23 \\
\hline Santo André/SP & 54 & 0,51 \\
\hline São José dos Campos /SP & 67 & 0,47 \\
\hline São José do Rio Preto/SP & 58 & 0,66 \\
\hline Vitória da Conquista/BA & 61 & 0,40 \\
\hline Alemanha $^{4}$ & $>60$ & --- \\
\hline Bélgica - região Bruxelas ${ }^{5}$ & $>66$ & --- \\
\hline Estados Unidos ${ }^{6}$ & 39 & --- \\
\hline Europa Ocidental ${ }^{7}$ & $\sim 66$ & $0,7-1,0$ \\
\hline Hong Kong ${ }^{8}$ & --- & $\sim 1,50$ \\
\hline Japão ${ }^{8}$ & --- & $\sim 0,68$ \\
\hline Suíça $^{9}$ & $\sim 45$ & $\sim 0,45^{\star}$ \\
\hline Estado de Vermont (EUA) ${ }^{10}$ & 48 & --- \\
\hline
\end{tabular}

1- Apenas RCD dispostos em aterros público - abril 1999 (Superintendência de Limpeza Urbana- SLU, 1999); 2- PAULELLA; SCAPIM, 1996; 3- Apenas RCD dispostos em aterros público (LIMPURB, 1999); 4 Internacionale Vereinigung Baustoff-Recycling - IVBR, s.d.; 5- Institut Bruxellois pour la Gestion de LEnvironnement, 1995; 6- C\&D Debris Recycling, 1998c; 7- B.P. Simons, Belgian Building Researche Institute; 8- HONG KONG, 1993; 9- MILANI, 1990; 10- DONOVAN, 1991.

* Percentual em revisão (C\&D Debris Recycling, 1998c); ** População The Times, 1994 
As Figuras 2.1 e 2.2 ilustram a origem dos RCD nos EUA e em aterros de Hong Kong, respectivamente, de acordo com a Agência de Proteção Ambiental (EPAUSA) em relatório anual de 1996 e do Departamento de Proteção ao Meio Ambiente (E.P.D. - Hong Kong), apud Pinto, 2000.

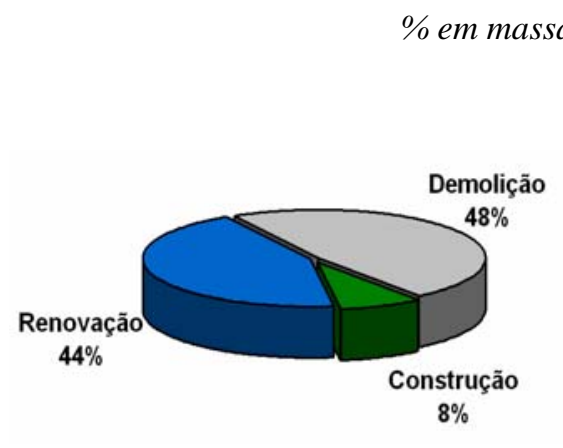

Figura 2.1 - Origem dos RCD nos EUA (YOST, 1998)

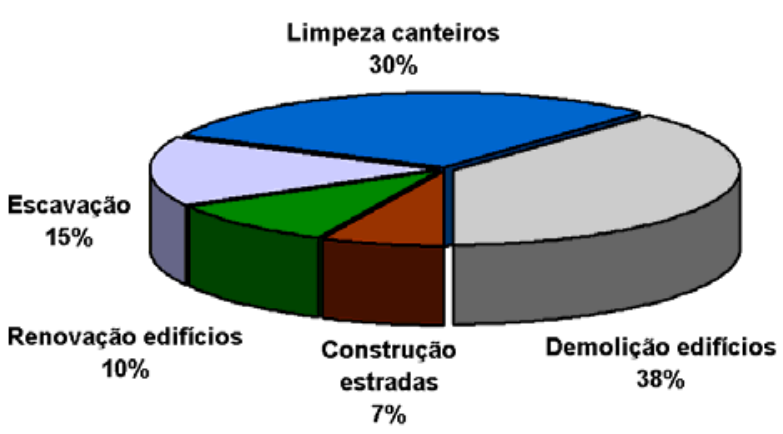

Figura 2.2 - Origem dos RCD em Hong Kong (Hong Kong, 1993)

\subsubsection{Perdas de materiais de construção}

Pinto (1989) investigou o índice de perdas e desperdício dos materiais de construção e também a composição média das fases presentes, considerando a "taxa de geração de resíduos de construção" da ordem de $150 \mathrm{~kg} / \mathrm{m}^{2}$ construído. Segundo o autor as perdas $^{7}$ no Brasil estão entre 20 e $30 \%$ da massa total, variando de acordo com a tecnologia empregada.

Pesquisas nacionais realizadas em 12 Estados apontam as perdas usuais de materiais em processos construtivos convencionais segundo três referências, conforme expresso na Tabela 2.3, apud Pinto (1999).

Verifica-se uma grande variabilidade dos valores encontrados por cada autor, esta que pode estar relacionada aos diferentes métodos construtivos ou à amostragem efetuada, entretanto, independente do valor numérico, a maior parte dos resíduos é composta por parcelas expressivas de material passível de ser reciclado.

\footnotetext{
${ }^{7} \mathrm{O}$ autor considera perdas toda a quantidade de material utilizada além das especificações de projeto que podem ser incorporadas à construção bem como descartadas como resíduos.
} 
Tabela 2.3 - Perdas de material em construções convencionais (apud PINTO, 1999)

\begin{tabular}{l|ccc}
\hline Material & PINTO $^{1}$ & SOIBELMAN $^{2}$ & FINEP/ITQC $^{3}$ \\
\hline \hline Concreto usinado & $1,5 \%$ & $13 \%$ & $9 \%$ \\
Aço & $26 \%$ & $19 \%$ & $11 \%$ \\
Blocos e tijolos & $13 \%$ & $52 \%$ & $13 \%$ \\
Cimento & $33 \%$ & $83 \%$ & $56 \%$ \\
Cal & $102 \%$ & --- & $36 \%$ \\
Areia & $39 \%$ & $44 \%$ & $44 \%$ \\
\hline \hline
\end{tabular}

1 Valores de uma obra (PINTO, 1989), 2 Média de 5 obras (SOIBELMAN, 1993),

3 Mediana de diversos canteiros (SOUZA, et al., 1998)

\subsubsection{Composição do RCD}

Os RCD são provenientes de diversas fontes e diferentes tipos construtivos, dessa forma verifica-se grande variabilidade composicional para os resíduos de diferentes países bem como entre os canteiros de obras (BOSSINK; BROUWERS, 1996; PINTO, 1986). Como exemplos de diferenças construtivas e costumes locais, citamse altos teores de madeira nos resíduos ingleses, norte-americanos e australianos (HARDER; FREEMAN, 1997; EPA, 1998; QUEENSLAND, 2003).

Podem também interferir na quantidade, composição e característica dos RCD alguns aspectos como: nível de desenvolvimento técnico da indústria da construção local; qualidade e treinamento da mão-de-obra disponível; técnicas de construção e demolição empregadas; programas de qualidade e redução de perdas empregadas; processos de reciclagem e reutilização adotados no canteiro de obras; disponibilidade e predominância de materiais na região; desenvolvimento econômico do local; demanda de novas construções (OLIVEIRA et al., 2004). Dessa forma, a composição do RCD está diretamente relacionada à região em que o mesmo foi gerado.

Dentre os principais constituintes do RCD citam-se material betuminoso, vidros, cerâmicas, concreto, argamassa, pedra britada, madeira, blocos e tijolos, papel, tintas, gesso, plásticos, metais e outros constituintes em menor quantidade (JOHN; ÂNGULO, 2003; GRIGOLI, 2000; OLIVEIRA; ASSIS, 1999). Dentre eles, os de origem não-mineral, madeira, plásticos, papéis e também gesso, dependendo da quantidade, afetam negativamente a resistência do concreto reciclado (CHEN et al., 2003; HENDRICKS e XING, 2004). 
O RCD europeu, de forma geral, apresenta teores de material não-mineral inferiores a $10 \%$, geralmente entre 2 e $3 \%$. Os resíduos na Alemanha são compostos por impurezas orgânicas, concretos leves e outros materiais porosos, cerâmicas com densidades entre 2,2 e $2,4 \mathrm{~g} / \mathrm{cm}^{3}$ e rochas naturais com densidades superiores a $2,5 \mathrm{~g} / \mathrm{cm}^{3}$; é acentuada a presença de concreto, ao contrário da argamassa. Já no Japão cerca de metade (51\%) do resíduo é composto por outros materiais, como plástico, papel e matéria orgânica e solo, com grande parcela de madeira.

As Figuras 2.3 e 2.4 ilustram a composição média dos RCD na Holanda e Japão, respectivamente.

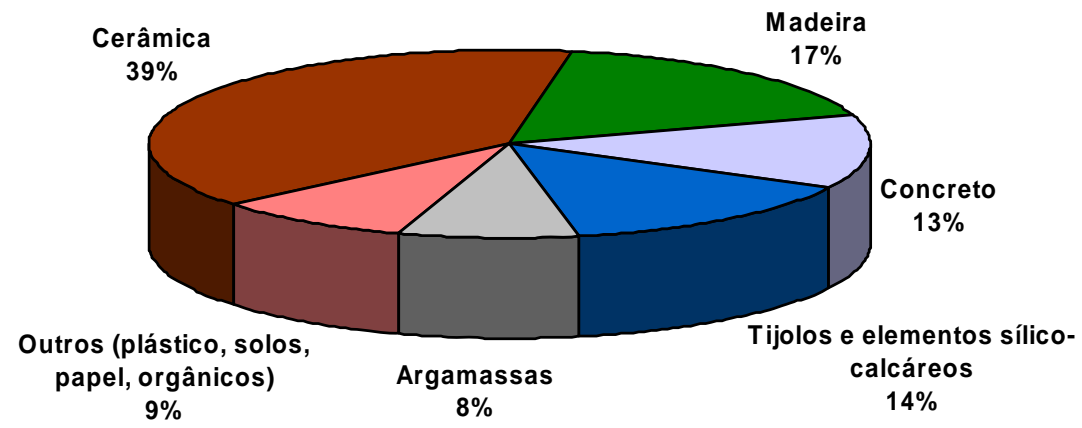

Figura 2.3 - Composição do RCD gerado na Holanda (BOSSINK; BROWERS, 1996)

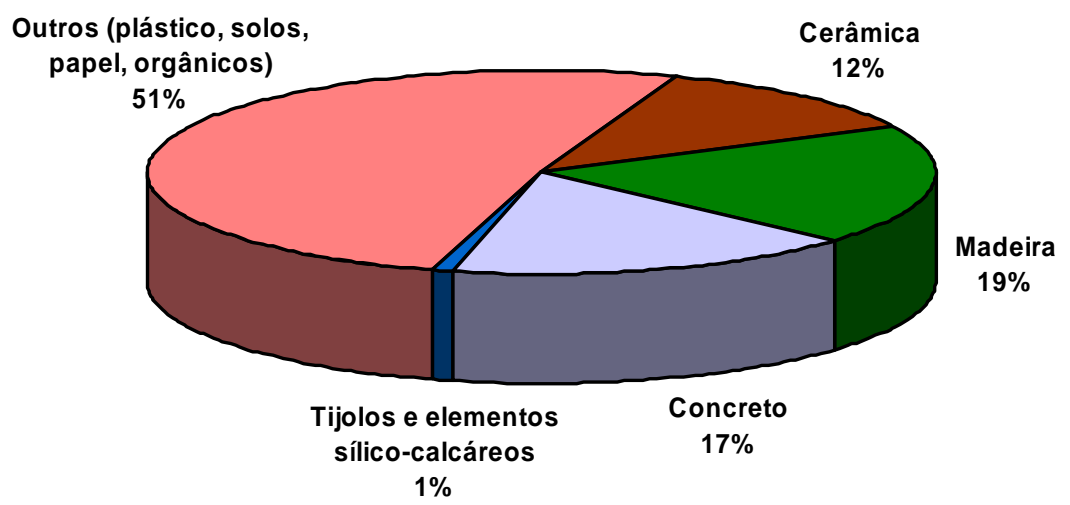

Figura 2.4 - Composição do RCD gerado no Japão (HONG KONG POLYTECHNIC, 1993), apud Levy (1997)

Como exemplo, em Salzburg (Áustria) os resíduos são essencialmente de concretos com presença de cerâmica vermelha ou branca, de tijolos e azulejos (Figura 2.5), sendo que a cerâmica vermelha é majoritariamente proveniente de construções 
antigas $^{8}$. Em menor proporção, verifica-se a presença de partículas leves orgânicas como plásticos e madeiras, utilizadas em compósitos de isolamento, juntamente com cimento (Figura 2.6).

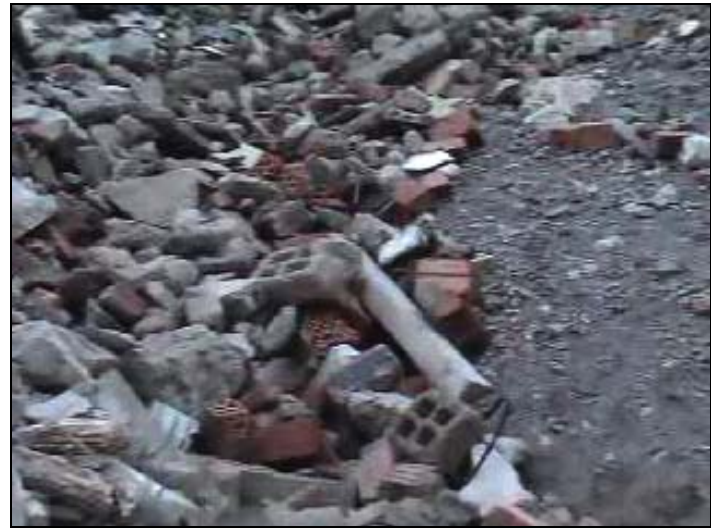

Figura 2.5 - Cerâmica vermelha junto com concreto

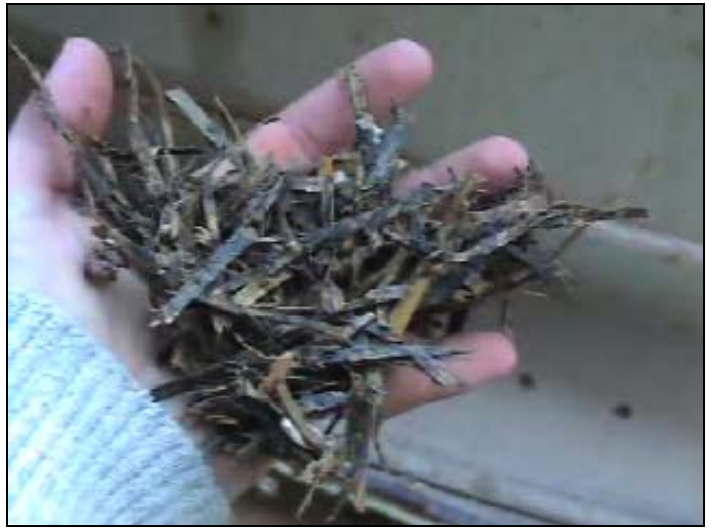

Figura 2.6 - Compósito de isolamento cimento madeira

Fonte: Sérgio C. Ângulo (inédito)

O RCD nacional é composto essencialmente por concreto e argamassa, rochas naturais e material cerâmico; apresenta, porém, grandes variações nas proporções de cada um destes, conforme ilustrado na Figura 2.7.

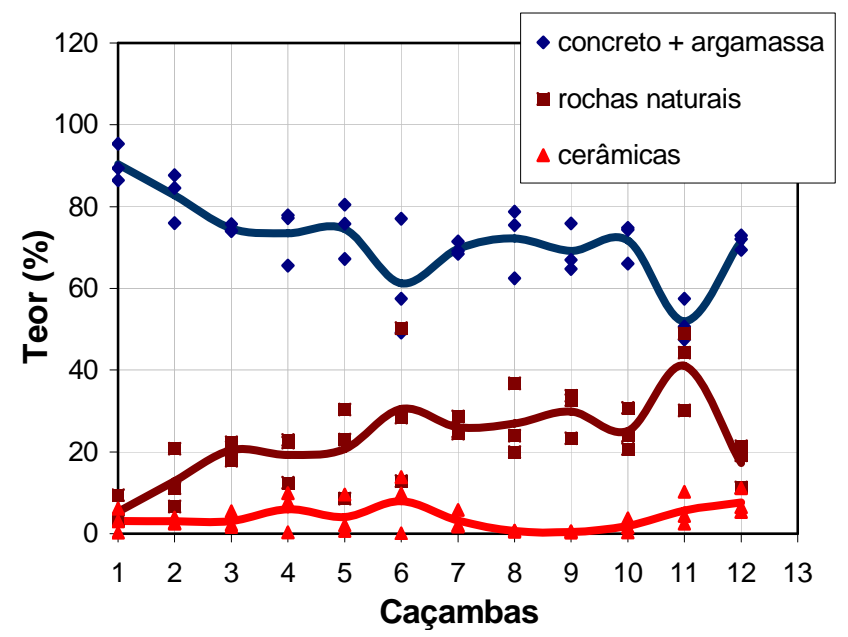

Figura 2.7 - Composição dos agregados de RCD reciclados para as diferentes caçambas avaliadas - avaliação por catação (ÂNGULO, 2000)

\footnotetext{
${ }^{8}$ As informações sobre as instalações austríacas assim como as fotografias foram obtidas em visitas de Sérgio C. Ângulo fomentadas pela Finep, projeto Verde Amarelo - Convênio 23.01.0673.00
} 


\subsubsection{Classificação do RCD para reciclagem como agregado}

Dentro do contexto internacional destaca-se a classificação do RCD em algumas classes. Na Europa, a fração mineral do RCD normalmente é classificada antes da britagem em resíduos de concreto, resíduos de alvenaria e resíduos mistos de concreto e de alvenaria (RILEM RECOMMENDATION, 1994; HENDRIKS, 2000), embora na Alemanha os resíduos de alvenaria sejam divididos em três classes diferentes (MÜLLER, 2004):

- Resíduo de tijolos: composto por tijolos recuperados em coberturas ou na préseleção dos resíduos de alvenaria podendo ser de natureza cimentícia ou cerâmica.

- Resíduos com altos teores de tijolos: compostos $80 \%$ da massa de tijolos e o restante de argamassa de assentamento e revestimentos provenientes da demolição de alvenarias.

- Resíduos de alvenaria mistos: compostos por tijolos, argamassas, revestimentos, concretos leves, tijolos sílico-calcários, etc. provenientes da demolição de alvenarias.

A norma brasileira (ABNT, 2004) também recomenda a classificação da fração mineral em resíduos de concreto e mistos; entretanto, é prática comum a classificação dos RCD em duas classes segundo a cor predominante:

- Tipo I ou cinza: predominantemente componentes de construção de natureza cimentícia, que inclui concretos e argamassas.

- Tipo II ou vermelho: componentes de construção de natureza cerâmica, principalmente vermelha.

A classificação é realizada em etapa anterior à britagem, de modo que sejam processadas separadamente segundo o mesmo circuito.

A Figura 2.8 ilustra a diferença visual entre os dois produtos (cinza e vermelho). O agregado proveniente do RCD mineral vermelho é empregado principalmente em bases de pavimentos. $\mathrm{O}$ agregado proveniente do RCD mineral cinza é empregado 
preferencialmente em calçadas, em blocos de concreto e em mobiliários urbanos à base de cimento, como bancos e outros.

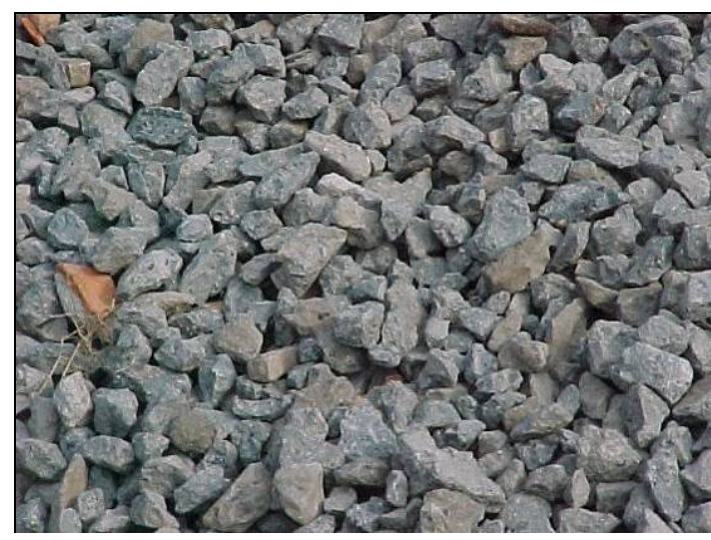

(a)

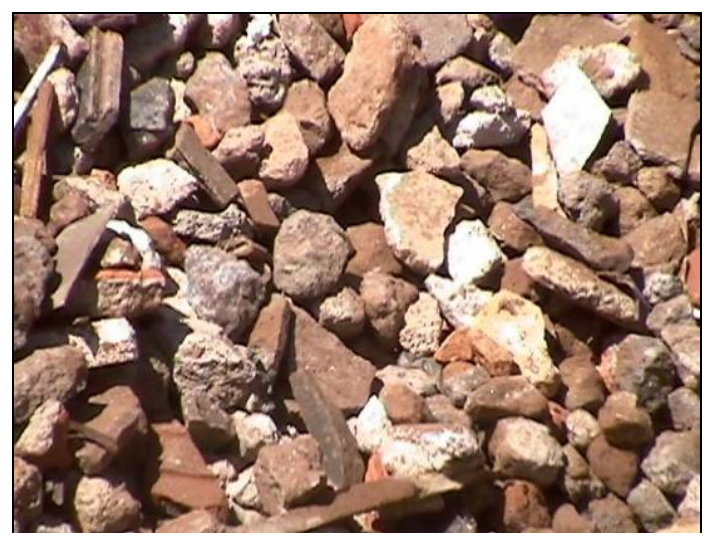

(b)

Figura 2.8 - RCD mineral cinza (a) e vermelho (b) da usina de Itaquera

\subsubsection{Gerenciamento e reciclagem do RCD}

Uma grande dificuldade em se tratando de RCD é a sua deposição. Na cidade de São Paulo mais de $20 \%$ dos RCD são depositados ilegalmente às margens de estradas, ruas e rodovias (Figura 2.9) (PINTO, 1999; ELIAS-OZKAN, 2001; EC, 2000).

Os RCD são de baixa periculosidade, entretanto o impacto associado a ele está relacionado ao grande volume gerado e à ausência de gestão adequada; incluem-se além dos aspectos ambientais também econômicos e sociais. Estima-se que o custo associado à coleta-transporte-deposição em aterros na cidade de São Paulo seja de $\mathrm{R} \$ 45 \times 10^{6}$ /ano (SCHNEIDER, 2003), sendo que os custos para remoção do material variam de 9 a 20 Reais $/ \mathrm{m}^{3}$ na região metropolitana e de 3 a 12 Reais $/ \mathrm{m}^{3}$ no interior paulista (LEAL, 1999). Em Belo Horizonte, o custo de reciclagem do RCD é da ordem de R \$ 5/t, inferior ao custo dos agregados naturais (PINTO, 1999).

A ausência de uma política de deposição adequada do resíduo permite a geração de áreas conhecidas como "bota-fora" e aterros clandestinos, provocando o assoreamento de córregos, entupimento de bueiros e galerias, degradação das áreas urbanas (PINTO, 1999; GAVILAN; BERNOLD, 1994; ZORDAN, 1997) e proliferação de animais peçonhentos e roedores (PINTO, 1999) afetando a saúde pública da população circunvizinha. 


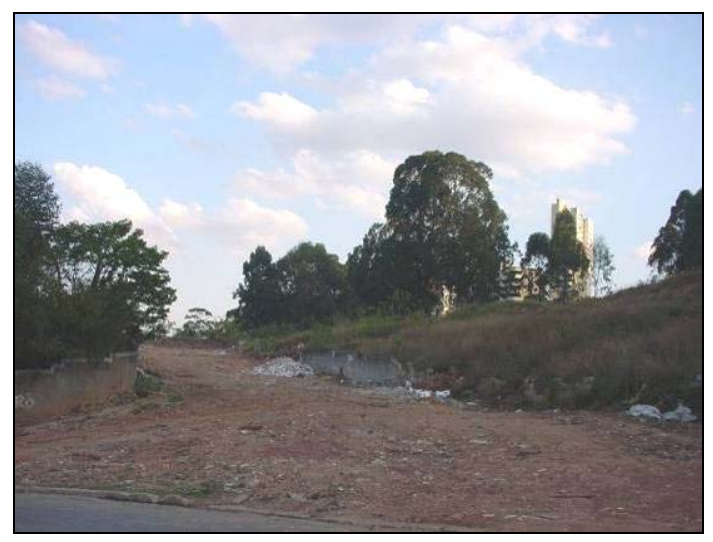

(a)

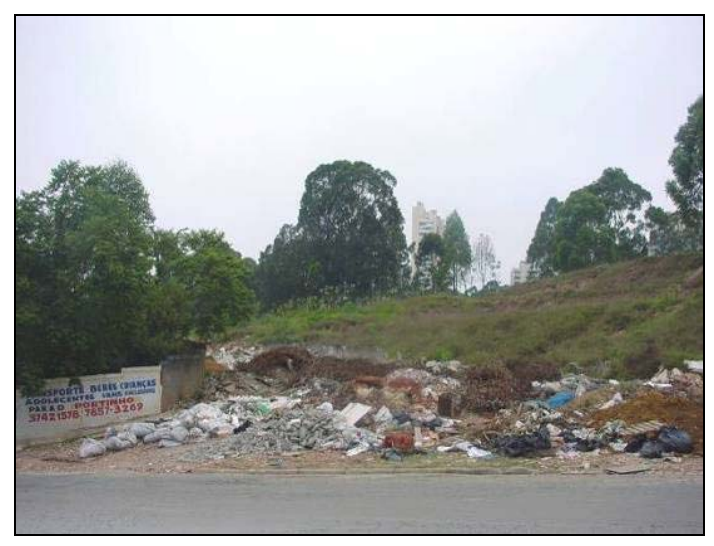

(b)

Figura 2.9 - Deposição ilegal na cidade de São Paulo

(a) rua utilizada como depósito clandestino limpa pela prefeitura em 30/08/2002. (b) a mesma rua após 2 meses. Foto de Vanderley M. John, 2002.

A deposição de RCD em aterros sanitários, no Brasil, foi proibida pela resolução 307 do CONAMA como forma de estimular a reciclagem, entretanto continua ocorrendo em função, essencialmente, dos custos de transporte (SYMONDS, 1999; PINTO, 1999; HENDRIKS, 2000). Segundo Ângulo e John (2002a), os componentes orgânicos (plásticos, tintas, óleos, asfaltos e madeiras), o amianto e algumas substâncias inorgânicas (como manganês) devem ser triados, pois podem contaminar os aterros; bem como sofrer eventual lixiviação vindo a contaminar o lençol freático (PENG et al., 1997).

Dessa forma, a reciclagem torna-se imperativa no sentido de aumentar a sustentabilidade do setor de construção à medida que reduz a utilização de aterros, a ocorrência de deposições irregulares e áreas de bota-fora, o consumo de recursos naturais não-renováveis e, indiretamente, os impactos ambientais associados às atividades de mineração.

No sentido de minimizar a deposição ilegal dos resíduos e aumentar a reciclagem, algumas medidas podem ser adotadas, dentre elas citam-se:

- Inserir áreas de coleta do resíduo dentro da malha urbana de modo a diminuir as distâncias de transporte e reduzir os custos associados.

- Adotar práticas de demolição seletiva a fim de reduzir a quantidade de outros materiais (amianto, gesso, fração não mineral entre outros) no RCD reciclável 
como agregado e melhorando sua qualidade (TRANKLER et al., 1996; WAHLSTROM et al., 1997; MULDER, 1997; RUCH et al., 1997; SCHULTMANN et al., 1997; HENDRIKS, 2000; FREIRE; BRITO, 2001).

- Paralelamente, implantar sistemas de triagem na fonte geradora, facilitando a distinção entre material reciclável e não-reciclável e, conseqüentemente, aumentando a reciclabilidade do material.

- Estimular a reciclagem da fração mineral.

Em países europeus a lei é rigorosa quanto à proibição de deposição de RCD em aterros sanitários (WILSON, 1996; HENDRIKS, 2000; EC, 2000; KOWALCZYK et al., 2000) ou, quando a legislação permite, esta operação é fortemente taxada (HOBBS; HURLEY, 2001; SCHULTMANN et al., 2001). Para minimizar os problemas gerados é comum a prática de triagem, que permite a separação entre os diferentes tipos de resíduos facilitando a reciclagem por processos distintos para cada tipo de material; esta pode ser realizada tanto nos centros geradores, como também em estações de triagem encontradas em países como Alemanha (aproximadamente 50 até o ano de 1997) (KOHLER; PENZEL, 1997), Brasil, Japão (SUZUKI, 1997) e Inglaterra (O'ROURKE, 2002). Paralelamente à triagem, a demolição seletiva é outra prática que aumenta as possibilidades de reciclagem do material, uma vez que facilita o processo de triagem.

Instalações de reciclagem são encontradas na maioria dos países membros; alguns objetivos foram traçados para se aumentar a taxa de reciclagem de RCD, tais como: duplicar o número de usinas de reciclagem na Alemanha (de 550 em 1992 para 1000 em 1998) (NORDBERG NEWS, apud PINTO, 1999) atingir 50\% de reciclagem na França; reduzir em $25 \%$ o material levado para aterros e quintuplicar a reciclagem na Suíça (MILANI, 1994), reduzir em 10\% a geração de RCD e aumentar para $25 \%$ a taxa de reciclagem até 2006. (ALEJOS, 2004).

$\mathrm{Na}$ Inglaterra, estava prevista uma tributação diferenciada sobre os agregados naturais para o ano de 2002, com objetivo de tornar o uso de agregados de RCD reciclados mais competitivo do ponto de vista econômico (HOBBS; HURLEY, 2001). Esse tipo de tributação diferenciada para agregados naturais também ocorre na Suécia, Dinamarca e Holanda (FHA, 2000). 
O Japão observou na década de 80 um significativo aumento na geração de RCD; passou de 30 para 84 milhões t/ano, o que encorajou o país a investir em novas tecnologias de reciclagem; em 1998 a taxa de reciclagem era de 22\%. Em 1991 já existiam 12 instalações de reciclagem de RCD em Tóquio, com equipamentos alemães, processando $10.000 \mathrm{t} /$ dia de $\mathrm{RCD}$ e gerando novos produtos de custo inferior ao dos agregados convencionais (HONG KONG, 1993, apud LEVY, 1997) para uso principalmente em obras viárias, as quais consomem $2 / 3$ do resíduo de concreto demolido gerado (VÁZQUEZ; BARRA, 2000).

Nos EUA a estimativa de reciclagem de RCD era de 20-30\% do total gerado, para o ano de 1996. No mesmo período foi estimada a existência de 1.800 usinas, das quais de 50 a $60 \%$ processavam asfalto, 30\% madeira, e de 15-20\% de resíduos mistos; em 1998 o número de usinas no país subiu para 3.500 (YOST, 1998).

No sentido de estimular a reciclagem da fração mineral de RCD, a Câmara Ambiental da Indústria da Construção do Estado de São Paulo, órgão da CETESB (Companhia de Tecnologia de Saneamento Ambiental) preparou diversas propostas de normas, discutidas e publicadas pela Associação Brasileira de Normas Técnicas (ABNT), a saber:

- NBR 15.112 - Resíduos da construção civil e resíduos volumosos - áreas de transbordo e triagem - diretrizes para projeto, implantação e operação.

- NBR 15.113 - Resíduos sólidos da construção civil e resíduos inertes Aterros - diretrizes para projeto, implantação e operação.

- NBR 15.114 - Resíduos sólidos da construção civil - Áreas de reciclagem diretrizes para projeto, implantação e operação.

- NBR 15.115 - Agregados de resíduos sólidos da construção civil - Execução de camadas de pavimentação - Procedimentos.

- NBR 15.116 - Agregados de resíduos sólidos da construção civil - Utilização em pavimentação e preparo de concreto sem função estrutural - requisitos

A prefeitura da cidade de São Paulo implementou aterros de inertes operados por empresas privadas, como o aterro de Itaquera (Figura 2.10). 


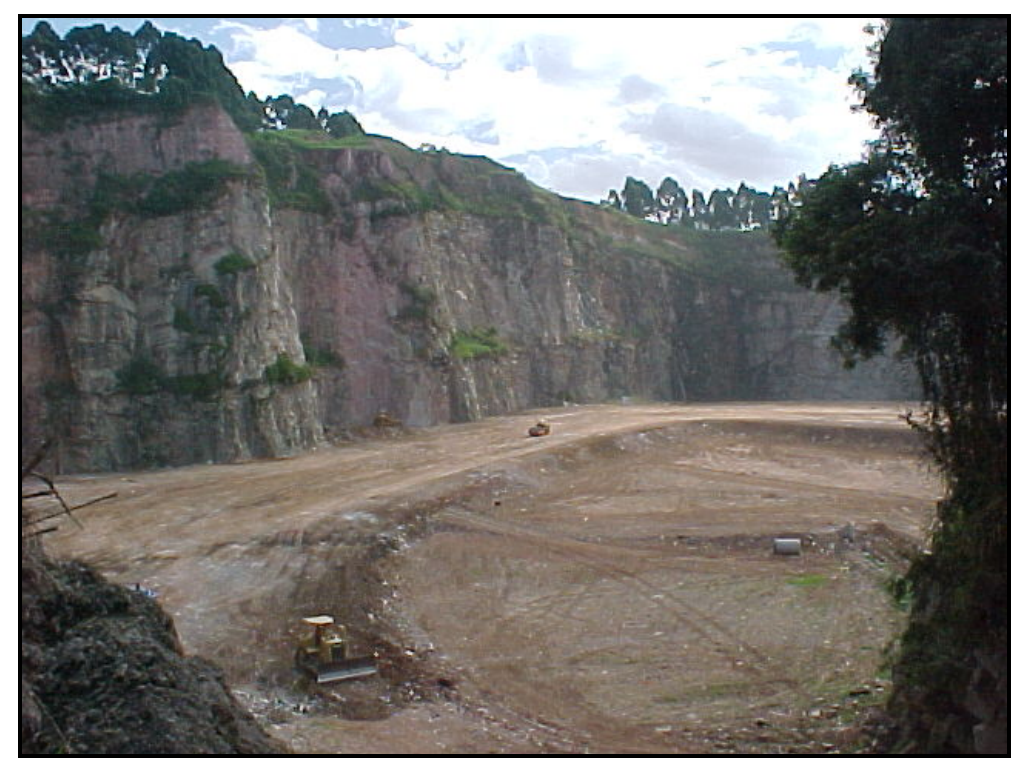

Figura 2.10 - Fotografia do aterro de Itaquera a partir de agregados reciclados de RCD Fonte: Carina Ulsen

\subsubsection{Resolução Conama}

O Conselho Nacional do Meio Ambiente - CONAMA é o órgão consultivo e deliberativo do Sistema Nacional do Meio Ambiente - SISNAMA. É de sua competência estabelecer diretrizes e normas técnicas relativas à proteção ambiental e ao uso sustentável dos recursos ambientais.

Considerando a necessidade de redução de impactos ambientais gerados pelos resíduos oriundos da construção civil aliado à viabilidade técnica e econômica de produção e uso destes materiais reciclados, foi estabelecido através da resolução 307 (CONAMA, 2002), em vigor desde janeiro de 2003, que os RCD pertencem à classe 9 de resíduos tipo $\mathrm{A}$, devido à sua composição combinada de concretos, argamassas, tijolos e telhas cerâmicas, rochas naturais e solos, dentre outros, são adequados para a reciclagem como agregados.

9 Classe A: resíduos reutilizáveis ou recicláveis como agregados compostos por diversos materiais de origem mineral, tais como produtos à base de cimento como blocos, concretos, argamassas, etc; produtos cerâmicos como tijolos, telhas, etc; rochas e solos entre outros; Classe B: resíduos recicláveis para outras destinações, tais como plásticos, papel/papelão, metais, vidros, madeiras, asfaltos e outros; Classe C: resíduos sem tecnologia de reciclagem disponível como, no caso brasileiro, o resíduo do gesso; $\underline{\text { Classe D: }}$ resíduos considerados perigosos, como tintas, solventes, óleos e outros 
Reitera ainda que o objetivo prioritário deva ser a não geração de resíduos e, secundariamente, a redução, reutilização, a reciclagem e destinação final; estando proibida a disposição destes em áreas de "bota-fora" (inclui aterros sanitários), em encostas, corpos d'água, lotes vagos e em áreas protegidas por lei.

A resolução contempla ainda um Plano Integrado de Gerenciamento de Resíduos da Construção Civil que deve ser elaborado pelos municípios e deve incorporar:

- Programa Municipal de Gerenciamento de Resíduos da Construção Civil a ser elaborado e implementado pelo município e deverá estabelecer diretrizes técnicas e procedimentos para o exercício das responsabilidades dos pequenos geradores, em conformidade com os critérios técnicos do sistema de limpeza urbana local.

- Projetos de Gerenciamento de Resíduos da Construção Civil elaborados e implementados pelos geradores não enquadrados no item acima; terão como objetivo estabelecer os procedimentos necessários para o manejo e destinação ambientalmente adequados.

Com a resolução do CONAMA, a adequada deposição dos resíduos torna-se indispensável para os pequenos e grandes geradores de resíduos, dessa forma a reciclagem torna-se objeto de grande prestígio frente à possibilidade de agregação de valor e comercialização do mesmo após um processo de beneficiamento.

\subsection{POSSIBILIDADES DE APLICAÇÕES PARA RECICLADOS DE RCD}

Apesar da reciclagem de resíduos classe A ser uma atividade bem antiga na Europa, a média de reciclagem ou reutilização neste continente é de apenas $25 \%$ do volume gerado (EC, 2000). De fato, existem países com alto índice de reciclagem e outros com reciclagem quase incipiente como Portugal e Espanha (EC, 2000). Mesmo os países que conseguiram atingir elevadas taxas de reciclagem do $\mathrm{RCD}$, como Holanda, Dinamarca e Alemanha, os agregados reciclados são absorvidos em grande parte pelas atividades de pavimentação (COLLINS, 1997; ANCIA et al., 1999; HENDRIKS, 2000). Esta prática é conhecida como downcycling (reciclagem de 
baixo valor), ou seja, empregar produtos de maior qualidade e valor agregado em aplicações, quando reciclados, de menor qualidade e de menor valor agregado (KOHLER; PENZEL, 1997).

A proibição da disposição de RCD reciclável em aterros sanitários é uma tendência em diversos países (HENDRIKS, 2000; EC, 2000), inclusive no Brasil (CONAMA, 2002), somando à tendência de saturação dos mercados usuais da reciclagem do RCD classe A (MULDER et al., 2003), torna-se evidente a necessidade de expansão do mercado da reciclagem incluindo o desenvolvimento de novos usos (MULDER et al., 2003).

De acordo com John e Agopyan (JOHN; AGOPYAN, 2000) as possibilidades de reciclagem estão relacionadas com a sua composição; as frações compostas predominantemente de rochas naturais e concretos estruturais podem ser recicladas para produção de concretos estruturais. Já a presença de fases mais porosas e com menor resistência mecânica, como argamassas e produtos de cerâmica vermelha implica em agregados de menor resistência mecânica e maior absorção de água; dessa forma verifica-se que é possível reciclar grande parcela do RCD gerado, em aplicações diferenciadas, a depender de suas propriedades e limitações técnicas.

A fração metálica do RCD pode ser comercializada em "ferros-velhos" ou reciclada como metais, da mesma forma os plásticos também são reciclados, a madeira reutilizada e a fração mineral pode ser reciclada para finalidades diversas.

A aplicação mais recorrente para o RCD reciclado é como material de preenchimento para preparação de terrenos, projetos de drenagem, sub-base de vias e estradas, fabricação de blocos de vedação, entre outras aplicações com baixa exigência de desempenho mecânico. Entretanto, esse mercado não é suficiente para consumir todo o RCD gerado, além de também ser pouco rentável (ANGULO et al., 2002). Estimase que as atividades de pavimentação e obras públicas nacionais absorvem até $84 \%$ da fração mineral do RCD gerado, e de 50 a 70\% em países europeus (COLLINS, 1997; BREUER et al., 1997; TOMAS et al., 1997; ANCIA et al., 1999; TOMAS et al., 1999; HENDRIKS, 2000; DIJK et al., 2002; XING et al., 2002; SCHULTMANN; RENTZ, 2000; KOWALCZYK et al., 2000; KOHLER; KURKOWSKI, 2002; MÜLLER, 2003). Essa aplicação é favorecida pela menor 
demanda em termos de exigências de qualidade do produto se comparado à utilização em concreto (RILEM RECOMMENDATION, 1994; HENDRIKS, 2000; ISWB, 2001).

No Brasil, o início das investigações sobre o uso dos RCD em obras de pavimentação data de 1989 sob supervisão da Prefeitura Municipal de São Paulo/SP, onde se averiguou a capacidade de suporte de solos tropicais típicos mediante a agregação de RCD. Os resultados obtidos indicaram o sucesso da iniciativa, facilitando o processo executivo em conseqüência de melhor homogeneização e menor dispersão da umidade (BODI et al., 1995); Tais propriedades são conhecidas por gestores urbanos, que não raramente utilizam RCD in natura para manutenção de vias secundárias.

A utilização do RCD como agregado em argamassa e concreto tem tido um expressivo desenvolvimento. Pinto (1986) não observou diferença na resistência à compressão nas argamassas quando substituiu agregados convencionais por reciclados, para os mesmos traços cimento:cal:agregado convencional:resíduo. Da mesma forma, Levi (1997) observou que o aumento na proporção de material cerâmico aumenta as resistências à compressão e tração da argamassa para traços cimento: RCD: areia de 1:1,5:6.

Outra tendência tem sido o estudo da aplicação de RCD como agregado reciclado. A denominação "agregado para construção civil" é utilizada no Brasil para identificar um segmento do setor mineral que produz matéria prima mineral bruta ou beneficiada de emprego imediato na indústria da construção civil, tais como argilas, areia e rocha britada. A ABNT NBR 7211 define como agregado graúdo a fração de brita proveniente de rochas estáveis cujos grãos sejam passantes em peneiras de abertura nominal 15,2 mm e retidos em 4,8 mm; agregados miúdos, por sua vez, estão enquadrados na faixa entre 4,8 e $0,075 \mathrm{~mm}$.

Os agregados reciclados podem ser de concreto e/ou de cerâmica, bem como agregados mistos de argamassa, cerâmica, concreto, rochas, madeira, plásticos, amianto, solo e cal, com predominância das fases inorgânicas não-metálicas.

Aplicações mais nobres para os agregados reciclados exigem maior controle de qualidade destes; propriedades físicas e químicas podem ser restritivas para algumas aplicações. A resistência à compressão do concreto é afetada pela porosidade do 
agregado utilizado; como os RCD possuem quantidades variáveis de aglomerantes (pasta de cimento endurecida porosa e cal), pode-se inferir que apresentarão maiores índices de absorção de água e, portanto, menor resistência à compressão (QUEBAUD-BUYLE-BODIN, 1999). A absorção de água é, portanto, um importante parâmetro a ser determinado na caracterização, bem como na decisão do equipamento de britagem a ser empregado, visto que a parcela de argamassa aderida a superfície dos agregados naturais (rochas) pode ser maior ou menor a depender dos mecanismos de cominuição.

Outro ponto crítico na utilização de concretos reciclados é a retração. Os agregados reciclados com maior quantidade de pasta aderida aos grãos de minerais apresentam maior absorção de água e logo um volume maior de água possível de evaporar e provocar retração (QUEBAUD-BUYLE-BODIN, 1999).

As expansões e reduções na resistência à compressão dos concretos estão diretamente relacionadas ao teor de sulfatos, às reações álcali-agregado e à presença de contaminantes. Segundo GALLIAS (1998), o teor limite de sulfatos é a partir de 1,2\%; o mesmo autor ainda afirma que as expansões e reduções na resistência são mais significativas quando aplicados agregados finos reciclados e que a presença de contaminantes, tais como: material betuminoso, solos, madeira, gesso, asfalto e tinta PVA, podem reduzir em até $30 \%$ a resistência à compressão dos concretos; o teor limite de material orgânico deve ser inferior a $0,15 \%$ da massa do agregado (B.C.S.J., 1997).

A aplicação de agregados reciclados em concretos plásticos, aos invés de agregados naturais, demanda maior consumo de cimento para se obter a mesma resistência mecânica (LEVY, 1997a; ZORDAN, 1997; DESSY et al., 1998).

Sabe-se que para a utilização de RCD em concreto é viável tecnicamente (HANSEN, 1992; ZORDAN, 1997; HENDRIKS, 2000), embora ainda não empregada por falta de tecnologia e controle de qualidade nas usinas de reciclagem (ANGULO; JOHN (2002). Para se obter agregados reciclados de maior qualidade passíveis de serem aplicados em concreto, exigem-se mudanças nos procedimentos e equipamentos atualmente empregados nas usinas de reciclagem, assim como na gestão do resíduo e normalização, dentre outras. Exemplos de melhorias para as quais devem ser 
desenvolvidas soluções tecnológicas adequadas ao mercado brasileiro são: segregação na origem, classificação mais adequada no recebimento do resíduo na instalação de reciclagem e a sofisticação dos processos de reciclagem, utilizando tecnologias de usina de minérios.

A substituição dos agregados reciclados por naturais para uso em concretos na Europa é dificultada face ao elevado rigor nas especificações; estas contemplam que o teor de partículas leves presentes nos agregados reciclados deve ser inferior a $0,1 \%$. Para atender tais quesitos a empresa Deisl-Beton (Áustria) emprega a jigagem na produção de agregados reciclados para produção de concretos usinados, o que tem possibilitado teores mais elevados de substituição de agregados naturais por reciclados. As densidades de corte são de 1,6 e $1,8 \mathrm{~g} / \mathrm{cm}^{3}$, de modo que a fração leve orgânica ou contaminantes seja removida até atingir valores inferiores a $0,01 \%$.

O uso de agregados de RCD reciclados em concretos ainda é bastante modesto (HENDRIKS, 2000). As principais recomendações estrangeiras para tal fim são discutidas por HANSEN, 1992; RILEM RECOMMENDATION, 1994; HENDRIKS, 2000, são elas: BSCJ, Holanda, Rilem Recomendation, Lima.

Há normas técnicas para o uso de agregados de RCD reciclados em concreto em países como Dinamarca, Holanda (HENDRIKS, 2000; HENDRIKS; JANSSEN, 2001), Alemanha (DIN, 2002), na Inglaterra (REID, 2003) e no Brasil (ABNT, 2004).

Em relação às normas citadas, a BCSJ é a mais antiga (HANSEN, 1992); a recomendação holandesa é importante por conter resultados de pesquisas experimentais realizados na década de 80 (HENDRIKS, 2000). Já a Rilem é resultante de um conjunto de pesquisas realizadas na Europa, Estados Unidos e Japão (RILEM RECOMMENDATION, 1994), sendo a única que prevê a produção de concretos com resistência mecânica acima de $20 \mathrm{MPa}$. A condição imposta é que os resíduos de concreto sejam triados como agregados graúdos para a produção de concretos com resistência de até $60 \mathrm{MPa}$ ou através de misturas de agregados graúdos de RCD reciclados com naturais até o limite de $20 \%$, dependendo da origem da fração mineral. A segunda situação também é admitida pela proposta de 
normalização espanhola (ALAEJOS et al., 2004), por HENDRIKS (2000) e pela norma inglesa (REID, 2003).

As recomendações da B.S.C.J. (HANSEN, 1992), no Japão, e de Lima (LIMA, 1999), no Brasil, são as mais conservadoras ao admitir um limite de resistência mecânica de $18 \mathrm{MPa}$ quando utilizados agregados provenientes de resíduos de concreto. A norma brasileira prevê o uso da fração miúda desses agregados, diferentemente da recomendação da RILEM, que considera essa fração muito porosa e contaminada (RILEM RECOMENDATION, 1994).

O comportamento do concreto a partir de agregados reciclados de RCD foi avaliado por Carrijo (2005), embora estudos anteriores (PINTO, 1995; ZORDAN, 1997) apontam bons resultados em composições com baixo consumo de aglomerantes quando os agregados, tanto miúdos quanto graúdos, são substituídos integralmente pelo reciclado.

Carrijo (2005) avaliou a influência da porosidade média dos agregados reciclados de RCD no comportamento mecânico e nas propriedades físicas do concreto. A autora ressalta que o RCD pode conter contaminações que interferem na qualidade do produto final e, para o concreto, o gesso é um dos principais contaminantes, podendo apresentar reações expansivas com o cimento Portland, sendo desta maneira um fator limitante à reciclagem.

O programa experimental desenvolvido por Carrijo envolveu a separação dos agregados por faixas de densidade para fabricação de agregados para concretos. Suas principais conclusões indicam que a porosidade do agregado, avaliada através da massa específica aparente, é uma propriedade mais relevante do que a natureza mineral do RCD que lhe deu origem e afeta diretamente suas propriedades mecânicas (resistência e módulo) e físicas (absorção e densidade).

Carrijo (CARRIJO, 2005) constatou que concretos produzidos com RCD de baixa densidade (inferior a $2,2 \mathrm{~g} / \mathrm{cm}^{3}$ ) apresentam menor resistência mecânica e maior absorção de água, tornando o concreto muito menos eficiente para aplicações estruturais e demandando elevado consumo de cimento para a mesma resistência mecânica, resultando em concretos mais caros e menos eficientes do ponto de vista de sustentabilidade. 
Além disso, a produção de concretos estruturais utilizando os agregados de RCD em escala industrial pode ser tecnicamente factível com a implantação de concentração densitária (jigues) nas usinas de reciclagem.

Quando utilizados em argamassas, o consumo de cimento pode ser reduzido ou manter-se constante; a retenção de água pode ser minimizada em até 15\% (LEVY, 1997a). Segundo Miranda (2000), o custo da argamassa produzida quando se tem substituição integral da areia pelo RCD reciclado pode ser reduzido em até $40 \%$. O mesmo autor afirma ainda que as argamassas produzidas com agregados reciclados são bem aceitas entre os trabalhadores da construção civil, apresentando boa plasticidade, adesão e desempenamento.

A substituição parcial de agregados naturais por reciclados para a produção de blocos de vedação foi estudada por Pauw (1982), que constatou que a resistência à compressão em nenhum caso foi fator limitante a sua aplicação. Collins (1998) afirma que a substituição de $75 \%$ de agregados de RCD reciclados na produção de blocos é possível sem qualquer dificuldade, apresentando bons resultados.

\subsection{CARACTERIZAÇÃO TECNOLÓGICA}

\subsubsection{Caracterização de matérias primas minerais}

A expressão caracterização tecnológica de matérias primas minerais, de modo geral, pressupõe um estudo dos recursos minerais, tendo em vista as tecnologias usuais de seu usina e o atendimento às especificações de mercado (SANT'AGOSTINHO; KAHN, 1997).

Para minérios as aplicações tecnológicas se vinculam ao seu aproveitamento e se reportam a dois segmentos tecnológicos distintos, o primeiro deles se refere às técnicas de exploração mineira ou lavra, o outro se reporta às atividades de beneficiamento/usina ou de adequação para a indústria de transformação.

Para fins do beneficiamento, volta-se à avaliação dos parâmetros básicos do corpo mineralizado, relacionados às alternativas tecnológicas de tratamento de minérios. Assim, envolve o conhecimento de matérias primas minerais nos aspectos relativos 
aos seus componentes minerais, já que o beneficiamento mineral tem por objetivo a separação física de seus constituintes.

A caracterização tecnológica é realizada através de uma série de ensaios e análises laboratoriais, segundo seqüência de procedimentos e critérios planejados fundamentalmente em função do bem mineral em estudo. A partir das informações sobre minérios similares, obtidas em literatura e/ou operações mineiras, esboça-se um roteiro de procedimento (op. cit.), descrito a seguir:

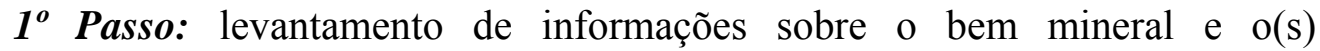
processo(s) beneficiamento aplicado em minérios e jazidas semelhantes;

$2^{o}$ Passo: dados sobre o bem mineral - informação orientativa - reunião de especificações de concentrados aplicadas por estas indústrias - faixas de teores desejados e elementos deletérios;

$3^{\circ}$ Passo: estabelecimento do método de estudo para o bem mineral em questão;

$4^{o}$ Passo: operações em laboratório: preparação de amostra, cominuição e classificação granulométrica, separações minerais. Estes ensaios são acompanhados do balanço de massa dos produtos gerados e análises químicas que resultam em um balanço metalúrgico; análises mineralógicas e formas de associações minerais também são relevantes.

Dentre os parâmetros avaliados nos estudos de caracterização tecnológica destacamse a distribuição em massa e dos elementos de interesse por fração granulométrica. A distribuição em frações grosseiras ou finas depende das dimensões e forma de associações dos grãos minerais e resistência a cominuição dos minerais; já as fases portadoras do elemento de interesse, na maioria das vezes, se distribuem de forma variável nos intervalos granulométricos. Daí a importância de se determinar os minerais portadores do elemento de interesse, a sua partição nas várias fases, e a distribuição destas fases na granulometria. Além das propriedades do mineral útil, são importantes os dados sobre os minerais de ganga para possíveis subprodutos, como também os elementos deletérios. 
Em se tratando de resíduos, estes mesmos conceitos são estendidos visando a otimização do aproveitamento destes. Para rejeitos de mineração este conceito é similar, à medida que há um mineral de particular interesse associado ou não a outros, o qual se pretende recuperar através de um processo que permita a sua individualização/recuperação. Para outros tipos de resíduos é necessário avaliar as suas características e usos potenciais para, então, estabelecer uma rota de usina, que possivelmente envolverá adequação granulométrica para posterior concentração da(s) fase(s) de interesse.

A caracterização dos RCD constitui um exemplo em que alguns parâmetros relevantes são: a composição química, as fases minerais presentes, a distribuição do material nos intervalos de densidade, a absorção de água, a liberação da pasta aderida aos grãos de minerais nos produtos separados por faixas densitárias, dentre outros.

\subsubsection{Caracterização mineralógica}

$\mathrm{Na}$ caracterização tecnológica as análises mineralógicas constituem-se um recurso essencial na identificação dos constituintes e determinação de suas propriedades. São de suma importância os recursos que possibilitam a quantificação das espécies minerais, viabilizando a determinação da composição mineral, ainda que estimativa, e do grau de liberação do mineral útil (SANT'AGOSTINHO; KAHN, 1997).

A identificação dos minerais componentes de uma amostra normalmente não é possível através de uma única técnica analítica, fazendo-se necessária a conjugação de duas ou mais; as mais utilizadas estão sumariadas na Tabela 2.4. 
Tabela 2.4 - Técnicas de identificação de espécies minerais (modificado de SANT'AGOSTINHO; KAHN, 1997)

\begin{tabular}{|c|c|c|}
\hline Técnica & Métodos / Equipamentos & Propriedades avaliadas \\
\hline Microscopia óptica & $\begin{array}{l}\text { - microscópios estereoscópicos } \\
\text { - microscópios ópticos de } \\
\text { polarização }\end{array}$ & $\begin{array}{l}\text { forma, cor, alterações, } \\
\text { propriedades ópticas, liberação, } \\
\text { associações minerais }\end{array}$ \\
\hline Difração de raios $X$ & - método do pó & estrutura cristalina \\
\hline $\begin{array}{l}\text { Microscopia eletrônica } \\
\text { de varredura }\end{array}$ & $\begin{array}{l}\text { - microscópio eletrônico de } \\
\text { varredura }\end{array}$ & $\begin{array}{l}\text { forma, associações minerais, } \\
\text { liberação }\end{array}$ \\
\hline $\begin{array}{l}\text { Sistemas de } \\
\text { microanálise }\end{array}$ & $\begin{array}{l}\text { - dispersão de energia (EDS) } \\
\text { - dispersão de comprimento } \\
\text { de onda (WDS) }\end{array}$ & $\begin{array}{l}\text { composição química de fases } \\
\text { minerais }\end{array}$ \\
\hline $\begin{array}{l}\text { Recursos } \\
\text { complementares }\end{array}$ & $\begin{array}{l}\text { - análises térmicas } \\
\text { - análise por infravermelho }\end{array}$ & $\begin{array}{l}\text { transformações de fases } \\
\text { composição química }\end{array}$ \\
\hline Luminescência & $\begin{array}{l}\text { - catodoluminescência } \\
\text { - fluorescência }\end{array}$ & $\begin{array}{l}\text { excitação por elementos } \\
\text { ativadores }\end{array}$ \\
\hline
\end{tabular}

\subsubsection{Difração de raios $X$}

A difração de raios X (DRX), segundo Cullity (1978), é uma ferramenta utilizada para determinação de estruturas cristalinas, equilíbrio de fases, medida de tamanho de partícula e determinação de orientação de um cristal, entre outras.

Os raios $\mathrm{X}$ são ondas eletromagnéticas acompanhadas por um campo elétrico em flutuação periódica; na difração utiliza-se radiação de comprimento de onda na faixa de 0,5 a $2,5 \AA$. A difração de raios $\mathrm{X}$ pelos cristais resulta de um processo de espalhamento elástico dos raios pelos elétrons dos átomos, sem mudança do comprimento de onda, é o chamado espalhamento coerente segundo a lei de Bragg $(\mathrm{n} \lambda=2 \mathrm{~d} \operatorname{sen} \theta)$.

A difração resultante de um cristal, compreendendo posições e intensidades das linhas de difração, é uma propriedade física fundamental do cristal, servindo tanto à identificação como ao estudo de sua estrutura (FORMOSO, 1984). A forma e as dimensões da célula unitária determinam a posição angular das linhas de difração, e o arranjo dos átomos dentro da célula unitária determina a intensidade relativa dessas linhas. 


\subsubsection{Microscopia estereoscópica}

O microscópio estereoscópico (Figura 2.11) é um equipamento binocular, que opera usualmente com aumentos inferiores a 100x possibilitando uma visualização tridimensional (estereoscópica) de áreas relativamente extensas.

É constituído basicamente por duas lentes convergentes: ocular e objetiva, montadas em posições fixas; a objetiva forma uma imagem real que é visualizada na ocular como imagem virtual e aumentada do objeto examinado.

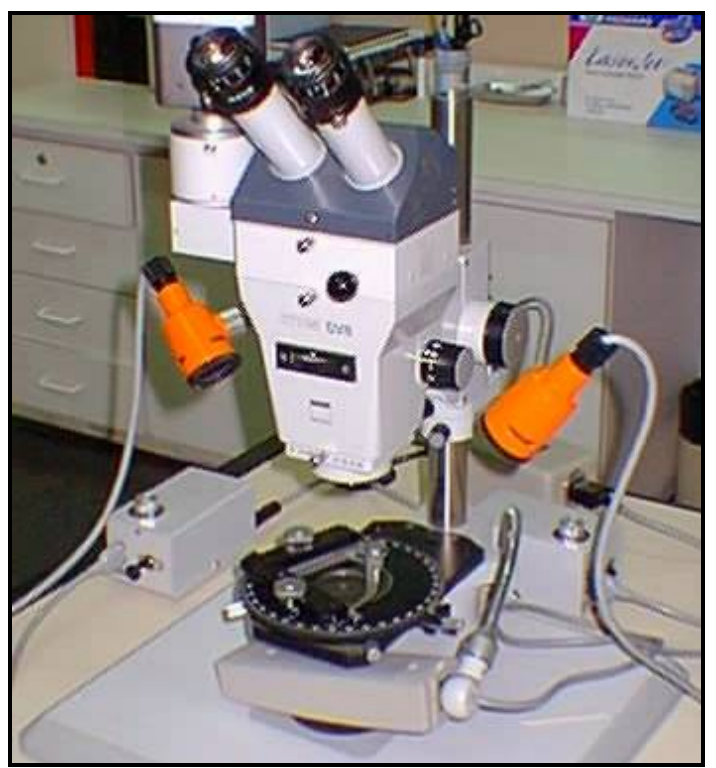

Figura 2.11 - Fotografia de um microscópio estereoscópico

\subsubsection{Microscopia óptica de polarização}

O microscópio de luz polarizada é um dos instrumentos mais utilizados por mineralogistas e engenheiros de minas para determinar as propriedades de uma vasta gama de minerais opacos e translúcidos (JONES, 1987). Sua principal aplicação é na identificação e quantificação de espécies minerais, definição de formas e associações minerais e grau de liberação (SANT'AGOSTINO; KAHN, 1997).

A principal diferença entre o microscópio de polarização e o microscópio estereoscópico á a presença de filtros polarizadores, constituídos, essencialmente, por substância orgânicas designadas por placas de polarização. A luz polarizada 
apresenta apenas uma direção de vibração, diferentemente da luz natural, permitindo, assim, a identificação de uma série de minerais através de suas propriedades ópticas. $\mathrm{Na}$ microscopia óptica de polarização por luz refletida (Figura 2.12) todo o dispositivo de iluminação situa-se acima da amostra e da lente objetiva; a luz incidente é desviada por um prisma para incidir perpendicularmente à amostra. Para a observação de minerais opacos faz-se necessário a confecção de seções polidas (Figura 2.14) ou delgadas polidas (Figura 2.15) a partir do corte e polimento de uma montagem dos grãos ou fragmentos de rocha em resina.
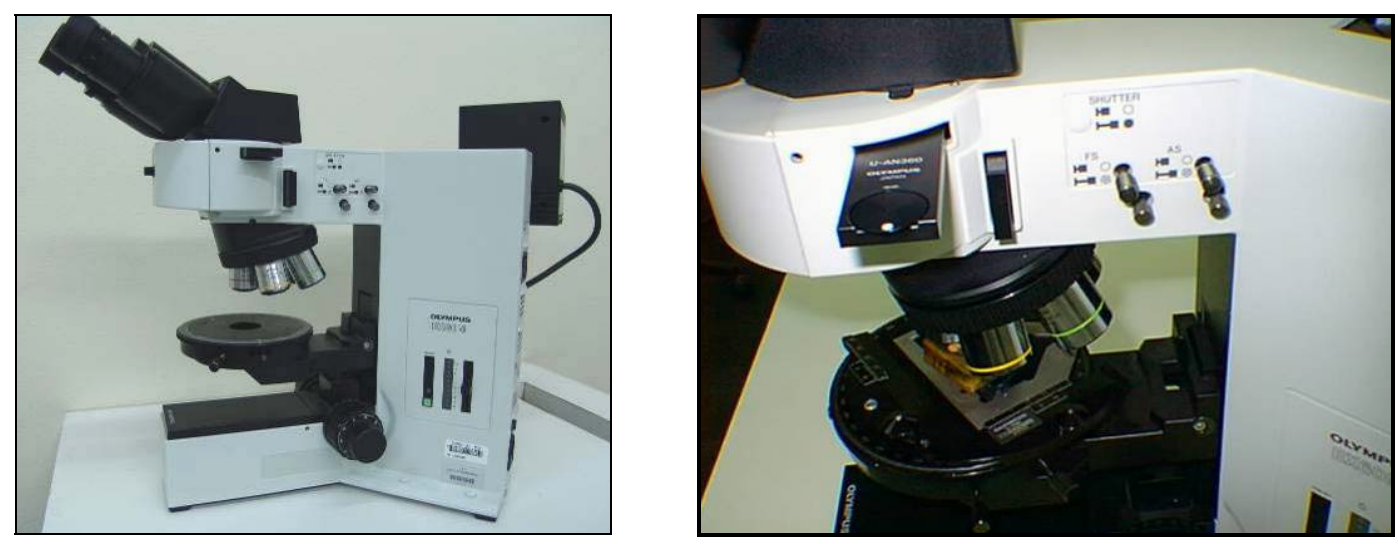

Figura 2.12 - Microscópio de luz refletida
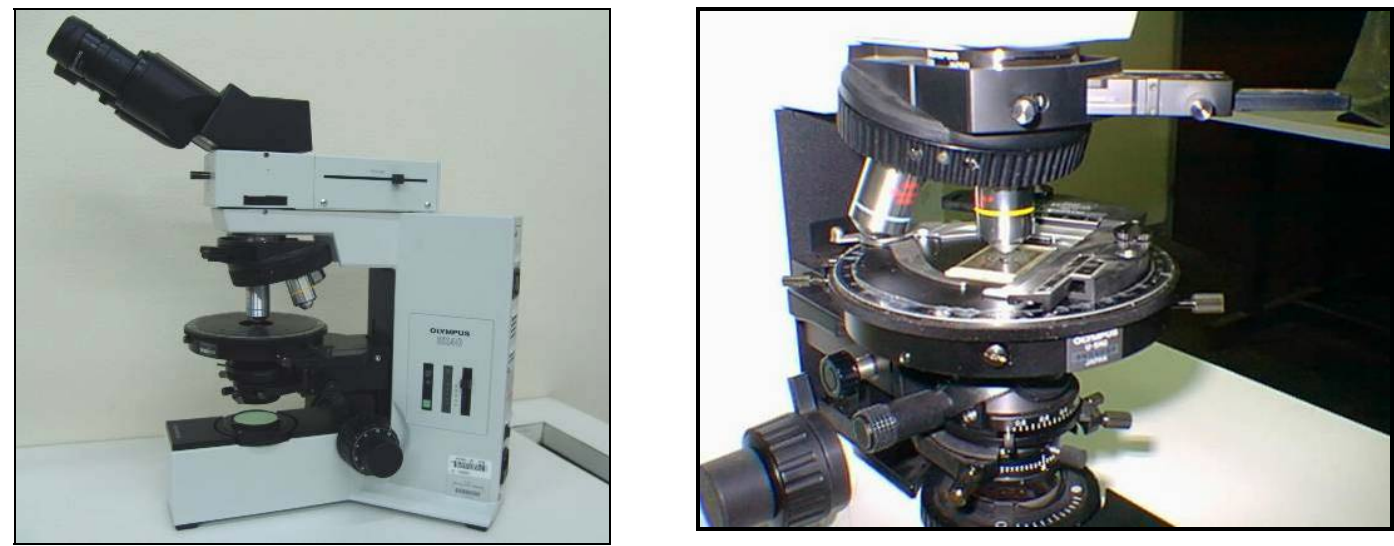

Figura 2.13 - Microscópio de luz transmitida

O microscópio de polarização por luz transmitida (ou microscópio petrográfico) (Figura 2.13) é um microscópio comum ao qual foram introduzidos dois fitros de polarização (ou nicóis), um denominado polarizador inferior ou simplesmente polarizador e outro polarizador superior ou analisador, orientados em direções de vibração ortogonais. É usualmente aplicado à observação de minerais translúcidos já 
que a técnica exige que a luz atravesse o mineral, por isso as amostras devem ser preparadas em seções delgadas polidas (Figura 2.15), delgadas (Figura 2.16) ou montagens de grãos.

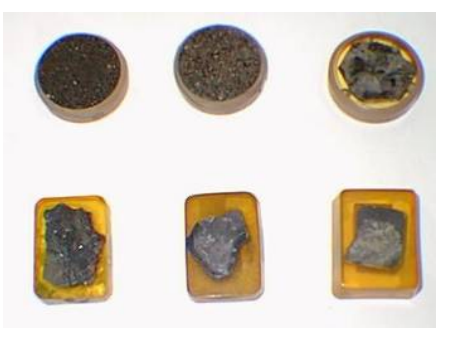

Figura 2.14 - Seção polida

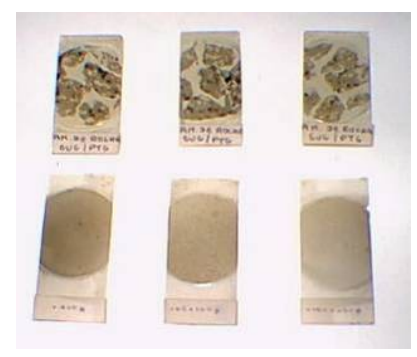

Figura 2.15 - Seções delgadas polidas

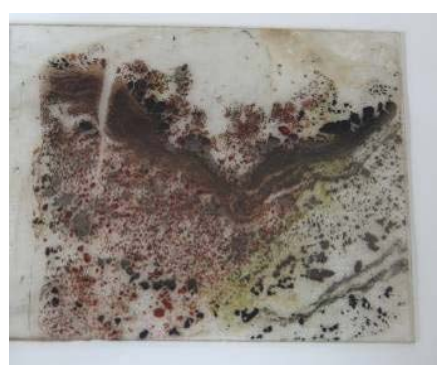

Figura 2.16 - Seção delgada

\subsubsection{Composição química}

Exemplos de técnicas instrumentais mencionadas por Willians (1996) para análise química são: espectrometria de absorção atômica (AAS), espectrometria de emissão por plasma de acoplamento indutivo (ICP-OES), espectrometria de massa por plasma de acoplamento indutivo (ICP-MS), análise de ativação neutrônica instrumental (INAA), cromatografia iônica (IC) e espectrometria por fluorescência de raios $\mathrm{X}$ (FRX). Dentre estas, as mais comumente empregadas na área de Engenharia Mineral são FRX, AAS e ICP-OES.

Na técnica de fluorescência de raios $X$, empregada no presente estudo, a amostra é pulverizada e prensada ou fundida em botões, sendo então irradiada por raios X. A irradiação da amostra por um feixe primário emanado de um tubo de raios $\mathrm{X}$ possibilita a excitação aos elementos químicos em geral $(Z>4)$ com a emissão de luz na região do espectro eletromagnético correspondente aos raios $\mathrm{X}(0,1$ a $100 \AA)$ (FORMOSO, 1984). A radiação resultante emitida pela amostra tem energia característica dos elementos presentes na amostra, cujas intensidades são proporcionais às suas concentrações. Para análise quantitativa são necessários procedimentos de calibração e comparação com padrões, podendo-se se fazer uso de espectrômetros com detector de comprimento de onda (WDS) ou de energia dispersiva (EDS). 


\subsubsection{Técnicas de separações minerais}

Os ensaios de separação têm por objetivo separar as diferentes espécies minerais, baseados em uma ou mais propriedades físicas que os diferenciam, a fim de individualizar os minerais de ganga do mineral útil (SANT'AGOSTINHO; KAHN, 1997).

Nestes ensaios atinge-se maior eficiência operacional, ou maior pureza de produtos, quanto mais estreita a faixa de dimensões de partículas nas frações, entretanto o fracionamento granulométrico excessivo nem sempre acrescenta informações relevantes podendo aumentar o tempo e custo dos estudos (op. cit.).

A escolha do método ou conjugação deles é baseada nas propriedades das espécies minerais componentes do mineral em estudo e a seleção do procedimento depende de disponibilidade e facilidade operacional (op. cit.).

\subsubsection{Separações em líquidos densos}

Segundo Burt (1984), a separação mineral em frações de densidade ${ }^{10}$ distintas é uma das técnicas de laboratório mais utilizadas, e tem como objetivos avaliar a aplicabilidade da separação em meio denso, verificar a variação da composição de um mineral, possibilitar a concentração de minerais em baixas concentrações para estudos mineralógicos e análise do grau de liberação do mineral, dentre outros. Esta técnica baseia-se na capacidade ou não de sedimentação das partículas quando imersas em líquido de uma dada densidade (SANT'AGOSTINHO; KAHN, 1997).

Separações em líquidos densos permitem realizar separações próximas da ideal em função da massa específica das partículas minerais (op. cit.). Em função da granulação do material, a separação em líquidos densos pode ser feita de três maneiras (BROWNING, 1961, PARFENOFF, 1970): em béqueres, em funis de separação e em centrífuga; em termos de eficiência e o principal problema da

\footnotetext{
${ }^{10}$ Define-se densidade como a relação entre as massas específicas de duas substâncias, sendo uma tomada como padrão. A rigor é uma grandeza adimensional utilizada freqüentemente em substituição ao termo massa específica aparente, que é a relação entre massa e volume da mesma amostra, expressa no SI em $\mathrm{kg} / \mathrm{m}^{3}$. O termo peso específico também é, algumas vezes, utilizado erroneamente ao invés de massa específica. Para fins práticos utiliza-se densidade e massa específica como sinônimos (BRASIL, 2004).
} 
separação por densidade refere-se ao usina das frações mais finas

Dentre os líquidos empregados têm-se:

- Soluções de sais em água - cloreto de zinco $\left(\mathrm{ZnCl}_{2}\right.$ até $\left.1,9 \mathrm{~g} / \mathrm{cm}^{3}\right)$ e de sais de tungstênio (SPT, LTM e LST até 3,3g/ $\mathrm{cm}^{3}$ - www.chem.com.au).

- Líquidos orgânicos densos - bromofórmio $\left(\mathrm{CHBr}_{3}-2,89 \mathrm{~g} / \mathrm{cm}^{3}\right)$, tetrabrometano - TBE $\left(\mathrm{CHBr}_{2} \mathrm{CHBr}_{2}-2,96 \mathrm{~g} / \mathrm{cm}^{3}\right)$ e di-iodeto de metileno $\left(\mathrm{CH}_{2} \mathrm{I}_{2}-3,32 \mathrm{~g} / \mathrm{cm}^{3}\right)$.

- Suspensões densas.

- Líquidos ou suspensões paramagnéticas (a densidade desejada é alcançada com o auxílio de campo magnético $\rightarrow$ separação em função de densidade e susceptibilidade magnética das partículas).

A utilização de líquidos orgânicos densos é técnica tradicional, sendo que os líquidos conhecidos cobrem a faixa de densidade de 1,6 até $4,3 \mathrm{~g} / \mathrm{cm}^{3}$. Frente a sua toxidade estes têm sido substituídos por sais de tungstênio solúveis em água. Densidades superiores podem ser alcançadas com suspensões densas, compostas de materiais densos micronizados, as quais, entretanto, apresentam problemas de estabilidade e têm uso menos difundido, ou mesmo mediante separação com fluídos paramagnéticos. A mesa Mozley (Mozley Mineral Separator) pode ser utilizada como alternativa para simular separações em densidades mais elevadas; opera em meio aquoso e realiza a separação através de movimentos oscilatórios que reproduzem os movimentos de bateamento, porém com resultados mais reprodutíveis (CAMPOS; LUZ, 1998).

\subsubsection{Separações magnéticas}

As técnicas de separações magnéticas baseiam-se na susceptibilidade magnética de cada espécie mineral para promover a sua separação - quanto maior for o seu valor, maior será a perturbação sofrida pela partícula na presença de um campo magnético (PARFENOFF, POMEROL \& TOURENQ, 1970; JONES, 1987).

A susceptibilidade magnética específica $(\mathrm{k})$ é uma constante adimensional que determina a resposta dos minerais a um campo magnético externo; dessa forma os minerais podem ser agrupados em três classes distintas (LUZ, et al, 2005): 
- Diamagnéticos: $\mathrm{k}<0$ - materiais que são repelidos quando submetidos a um campo magnético convergente. Ex: quartzo, magnesita, calcita, barita, esfalerita, cerusita.

- Paramagnéticos: $0<\mathrm{k}<10-3$ - são fracamente atraídos por campos magnéticos convergentes. Ex. hematita.

- Ferromagnéticos: materiais fortemente atraídos por campos magnéticos convergentes com alta susceptibilidade. Ex. magnetita.

Há atualmente uma grande variedade de equipamentos de separação magnética para uso industrial e laboratorial. Dentre os principais destacam-se os separadores magnéticos de rolos e tambores de terras raras, separadores magnéticos de rolos com pólos de imãs permanentes, separador magnético de alta intensidade via úmida (tipo carrossel), separador magnético de tambor e separador magnético de correias cruzadas. Cada equipamento apresenta características de campo magnético e gradiente de campo adequadas para diferentes finalidades e também com variações para processos a seco ou úmido.

Muitos dos equipamentos citados são também fabricados em escala laboratorial, como separadores de terras raras, de rolos e de tambor via seca ou úmida, alta intensidade via úmida (WHIMS), entre outros. Entretanto há alguns equipamentos utilizados exclusivamente para em ensaios de separação magnética em escala descontínua (laboratório), como: imã permanente tipo Alinco, separadores Frantz, separadores de alta intensidade via úmida (WHIMS), tubo Davis e separadores de rolos.

Os imãs permanentes são preferencialmente aplicados quando da presença de minerais ferromagnéticos (magnetita, pirrotita). Os separadores Frantz são de uso tradicional em laboratórios por apresentarem um desempenho operacional otimizado. Tais separadores operam a seco, submetendo um fluxo de partículas a um campo magnético com intensidade variável.

A principal vantagem oferecida por estes separadores reside na grande flexibilidade de condições operacionais (PARFENOFF, POMEROL \& TOURENQ, 1970; JONES, 1987; ABOUZEID, 1990). Os ajustes possíveis são: corrente da bobina que 
gera o campo magnético, inclinação longitudinal da calha por onde passa o material (que controla o tempo de ação do campo sobre a partícula) e a inclinação transversal; dessa forma é possível determinar uma condição de operação otimizada para se obter separações mais seletivas, principalmente, quando envolvem materiais paramagnéticos com susceptibilidades muito próximas.

Existem dois modelos básicos deste equipamento, com princípios operacionais distintos: o tipo isodinâmico (Figura 2.17) e o de barreiras (Figura 2.18). O Frantz isodinâmico mantém a força magnética sobre as partículas constante ao longo de toda a zona de separação ao passo que o de barreiras possibilita um gradiente de campo mais elevado, possibilitando a separação em faixas de susceptibilidade um pouco mais amplas (materiais diamagnéticos) e com maior capacidade de alimentação.

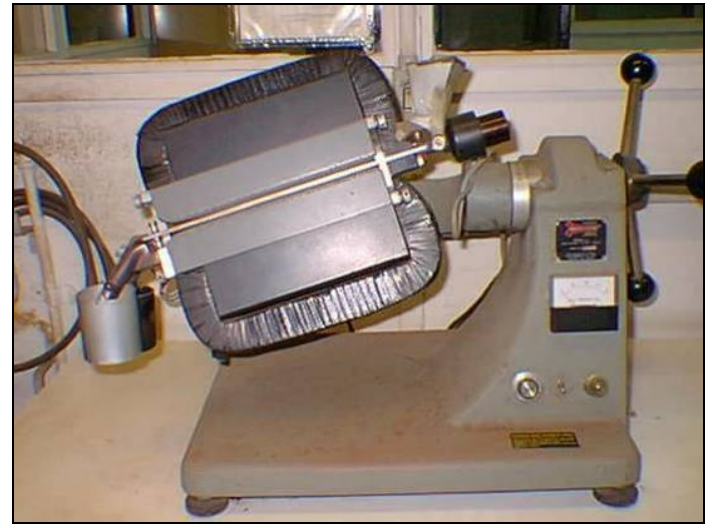

Figura 2.17 - Frantz isodinâmico

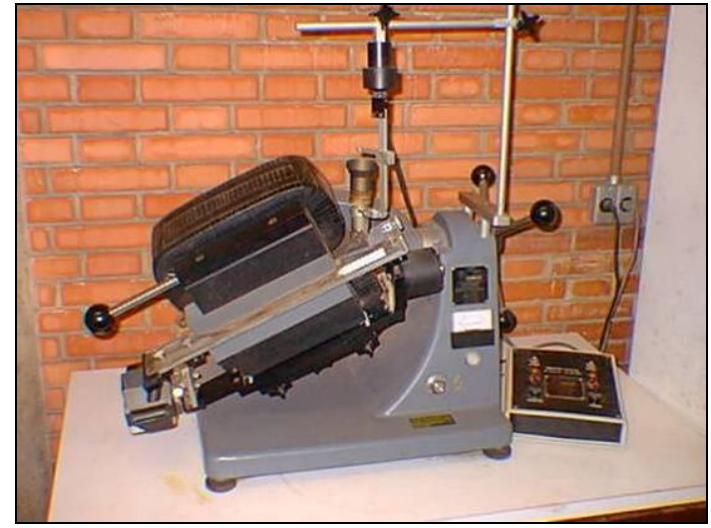

Figura 2.18 - Frantz de barreiras

Os separadores de rolos induzido (IMR) ou de terras raras são menos sensíveis do que os separadores Frantz, em contrapartida são capazes de processar maior quantidade de amostra por unidade de tempo (JONES, 1987). A separação é realizada pelo desvio do percurso de partículas com maior susceptibilidade magnética, em um campo magnético gerado por uma bobina.

Outro equipamento recorrente em caracterização é o tubo Davis. É constituído basicamente por um tubo de vidro, um conjunto de bobinas, um sistema de acionamento e suportes ajustáveis para geração de um campo magnético de 4.000 Gauss, que corresponde à intensidade magnética adequada para materiais de alta 
susceptibilidade magnética à medida que proporciona forças magnéticas de baixa intensidade. As partículas minerais, usualmente suspensas em meio aquoso, atravessam o tubo disposto entre os dois pólos que capturam as espécies minerais magnéticas.

Há ainda separadores que trabalham a úmido com o emprego de matrizes (WHIMS Figura 2.19 e HGMS) promovendo a separação a partir da captura dos minerais magnéticos em uma malha de fios ou matriz imantada, a partir de um fluxo de partículas suspensas em meio aquoso. O desempenho da operação é controlado por meio da regulagem do fluxo de alimentação (velocidade e densidade de sólidos na suspensão), características construtivas da matriz e da intensidade do campo magnético aplicado. São indicados para separação de minerais fracamente magnéticos contidos em minérios na faixa granulométrica entre 0,84 e $0,037 \mathrm{~mm}$; por exemplo, no tratamento de fosfato, bauxita, cromita, areia para vidro e materiais cerâmicos (INBRAS).

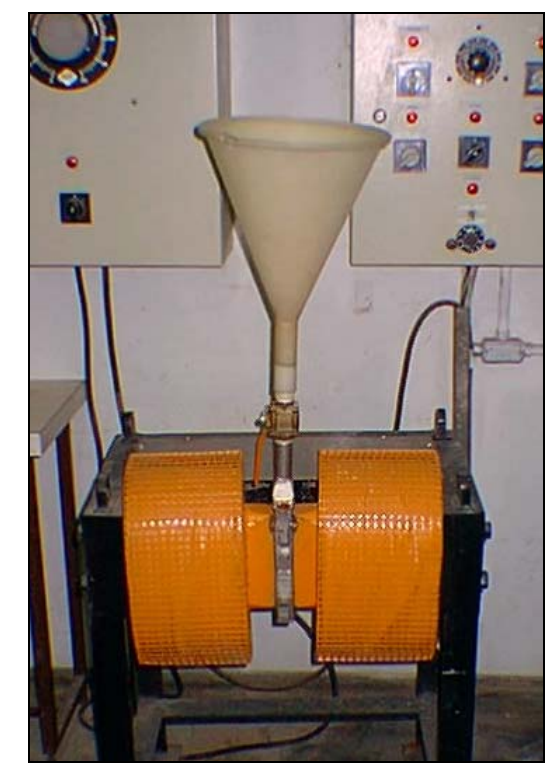

Figura 2.19 - Equipamento de separação magnética de alta intensidade via úmida (WHIMS) 


\subsubsection{Curvas de separabilidade}

As separações minerais são regidas por propriedades físicas ou físico-químicas diferenciadoras entre os minerais de interesse e a ganga. A eficiência das separações minerais, segundo qualquer destas propriedades, pode ser avaliada através de curvas de separabilidade.

Estas foram inicialmente aplicadas a separações de carvão em que o material era lavado para remoção das cinzas e foram, portanto, denominadas curvas de lavabilidade (washability curves - BURT, 1984). Entretanto, como representam propriedades características do mineral e podem ser aplicadas a maior parte das separações, são mais propriamente denominadas por "curvas de separabilidade" (KELLY, SPOTTTISWOOD; 1982).

As curvas de separabilidade possibilitam a previsão do comportamento do material na separação, uma vez que representa a distribuição de uma propriedade física do minério (SANT'AGOSTINHO; KAHN, 1997). Ressalta-se que a curva de separabilidade indica a separação ideal, ou o máximo de separação que pode ser alcançado em função de suas propriedades físicas das várias espécies presentes, significando meta a ser buscada no processo. A caracterização tecnológica procura determinar as curvas de separabilidade, fornecendo os parâmetros da matéria prima mineral que, em complemento com dados de eficiência de separação e da equação que a rege, possibilitam simulações matemáticas da separação a ser obtida no processo em escala industrial (op. cit.).

Podem ser representadas de forma gráfica por meio de histogramas, curva de freqüência ou freqüência acumulada, como também de forma numérica por funções matemáticas. Os dados necessários para a determinação de uma curva de separabilidade são obtidos por ensaios de separação realizados em laboratório e podem ser: classificação por tamanho, separação em líquidos densos, separação magnética ou por flotação. A partir das curvas de separabilidade em função de distintas propriedades fisicas é possível também se avaliar qual a propriedade mais adequada para uma dada separação (KELLY, SPOTTTISWOOD; 1982). 


\subsection{Curvas de separabilidade por densidade}

As curvas de separabilidade por densidade são normalmente determinadas mediante o emprego sucessivo de líquidos densos com densidades crescentes. Para cada densidade são gerados dois produtos: afundado (sink) e flutuado (float). Os produtos resultantes devem ser analisados para determinação dos elementos/compostos de interesse e, então, determinadas as curvas de separabilidade. Esta curva mostra o percentual, em massa, de afundados ou flutuados que é esperado para qualquer densidade de separação, e pode ser expressa para densidades crescentes ou decrescentes (KELLY, SPOTTTISWOOD; 1982).

O aspecto da curva depende do grau de liberação dos minerais útil(eis) e de ganga. No caso ideal, com os minerais de ganga e úteis completamente liberados, selecionase um líquido de densidade intermediária em que um deles se concentre totalmente no flutuado e o outro no afundado, dessa forma a curva de separabilidade terá dois degraus cuja largura será determinada pela diferença de densidade entre os minerais (Figura 2.20, caso a). Se os minerais estão completamente não liberados, a separação não é possível, então a curva será uma reta vertical na densidade do minério em que todo ele é flutuado ou afundado na densidade referida (Figura 2.20, caso b); na prática, porém, nenhuma destas situações se concretiza uma vez que haverá alguma liberação de qualquer um dos minerais e a curva é, portanto, variável em função do grau de liberação dos minerais (Figura 2.20, caso c).

(a)

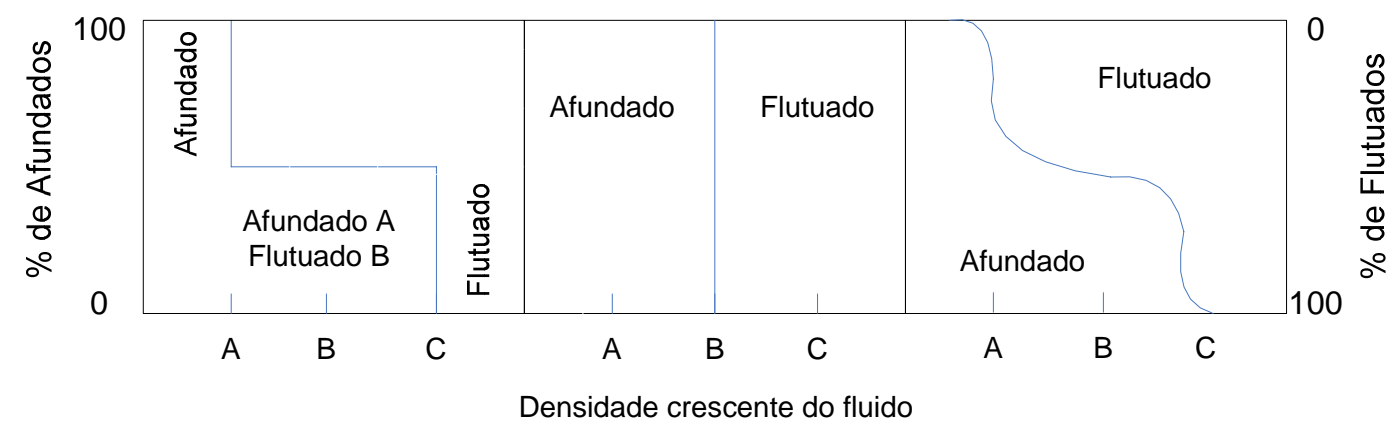

(a) Minerais totalmente liberados

(b) Minerais totalmente não liberados

(c) Curva típica de dois minerais

Figura 2.20 - Curva de densidade (BURT, 1984) 
Em geral, uma curva com ponto de inflexão bem definido e baixa declividade na seção média indica boa liberação; somente isso, entretanto, não garante uma separação fácil já que depende também da diferença de densidades entre as espécies minerais (BURT, 1984).

Quando a curva tem um ponto de inflexão indistinguível e uma declividade constante ao longo da curva, problemas na separação devem ser esperados pela presença de partículas mistas em todas as faixas de densidade (near gravity material). Este tipo de curva deve ser analisado com cautela e nunca deverá ser um indicativo único da separabilidade (op. cit.).

\subsection{BENEFICIAMENTO MINERAL}

O beneficiamento mineral compreende um conjunto de operações unitárias com o objetivo de se determinar características específicas de uma matéria-prima, separação dos seus constituintes minerais, adequação de tamanho, etc., no qual não existe qualquer alteração da estrutura interna do mineral tais como reações químicas, metalúrgicas ou cerâmicas. Estas operações unitárias são classificadas em quatro tipos: de redução, de classificação, de concentração e auxiliares (CHAVES, 1996; SANT’AGOSTINHO; KAHN, 1997; LUZ et al., 1998; JONES, 1987).

As operações de redução ou cominuição são utilizadas para se adequar o tamanho das partículas para a utilização imediata ou para as operações subseqüentes; as operações de classificação separam as partículas por faixa de tamanho, através de peneiras e classificadores (WILSON, 1996; CHAVES, 1996; LUZ et al., 1998).

As operações de concentração são empregadas quando existem várias espécies minerais presentes em um minério e o objetivo é aumentar o teor de mineral útil; podem ser realizadas por diferentes propriedades físicas dos minerais como densidade, cor, forma, propriedades elétricas, propriedades magnéticas, etc ou propriedades físico-químicas de superfície. Diversas operações unitárias podem ser utilizadas como catação, separação magnética, separação em meio denso e flotação, dentre outras (CHAVES, 1996; LUZ et al., 1998; HANISCH, 1998). 
A Tabela 2.5 (LUZ et al., 1998; KAHN, 1999; SMITH; COLLIS, 1993) resume os principais equipamentos utilizados nas operações unitárias do tratamento de minérios.

Tabela 2.5 - Descrição de alguns equipamentos industriais utilizados nas operações unitárias (SANT`AGOSTINO; KAHN, 1997 adaptado; KELLY; SPOTTISWOOD, 1982).

\begin{tabular}{|c|c|c|}
\hline Operação unitária & Tipo de operação & Equipamentos industriais \\
\hline \multirow[b]{2}{*}{ Cominuição } & britagem & mandíbula, giratório, impacto, rolos, etc \\
\hline & moagem & $\begin{array}{l}\text { moinho de bolas, de barras, de martelos, } \\
\text { vibratório, Raymond, rolos, etc }\end{array}$ \\
\hline \multirow{2}{*}{$\begin{array}{l}\text { Separação de } \\
\text { tamanho }\end{array}$} & classificadores & horizontais, verticais, espiral, ciclones \\
\hline & peneiramento & rotativo (Tromel), vibratório, estático \\
\hline \multirow{4}{*}{ Concentração } & por densidade & $\begin{array}{l}\text { calha simples, calha estrangulada, espirais, mesa } \\
\text { plana, jigue, mesa oscilante, ciclones ou cones de } \\
\text { meio denso, tambores de meio denso, centrífugas }\end{array}$ \\
\hline & $\begin{array}{l}\text { por susceptibilidade } \\
\text { magnética }\end{array}$ & $\begin{array}{l}\text { ímã permanente de baixa intensidade, separador } \\
\text { de rolos induzidos, separador magnético de alto } \\
\text { gradiente, separadores de tambor e de rolos de } \\
\text { terras raras, alta intensidade via úmida }\end{array}$ \\
\hline & $\begin{array}{l}\text { por condutibilidade } \\
\text { elétrica }\end{array}$ & $\begin{array}{l}\text { separador de rolos, separador de placas, } \\
\text { separador de alta tensão }\end{array}$ \\
\hline & $\begin{array}{l}\text { físico química de } \\
\text { superfície }\end{array}$ & células ou colunas de flotação. \\
\hline
\end{tabular}

\subsection{RECICLAGEM DA FRAÇÃO MINERAL DE RCD}

A reciclagem de RCD nada mais é que um beneficiamento mineral o qual tem por objetivo produzir frações de qualidade homogênea a partir de uma alimentação heterogênea empregando a melhor técnica de separação para alcançar assim alta eficiência segundo aspectos econômicos e ambientais.

Usualmente o usina de RCD contempla uma adequação granulométrica e remoção das frações de finos e magnéticos (metais). Segundo Ancia (1999) a massa específica parece ser a melhor propriedade para separar os RCD (tijolos, concretos, rochas naturais) das impurezas associadas, visando aplicações mais nobres. A Figura 2.21 mostra as operações unitárias que podem ser empregadas no usina de RCD (adaptado de JONES, 1987; JUNGMANN, 1999). 


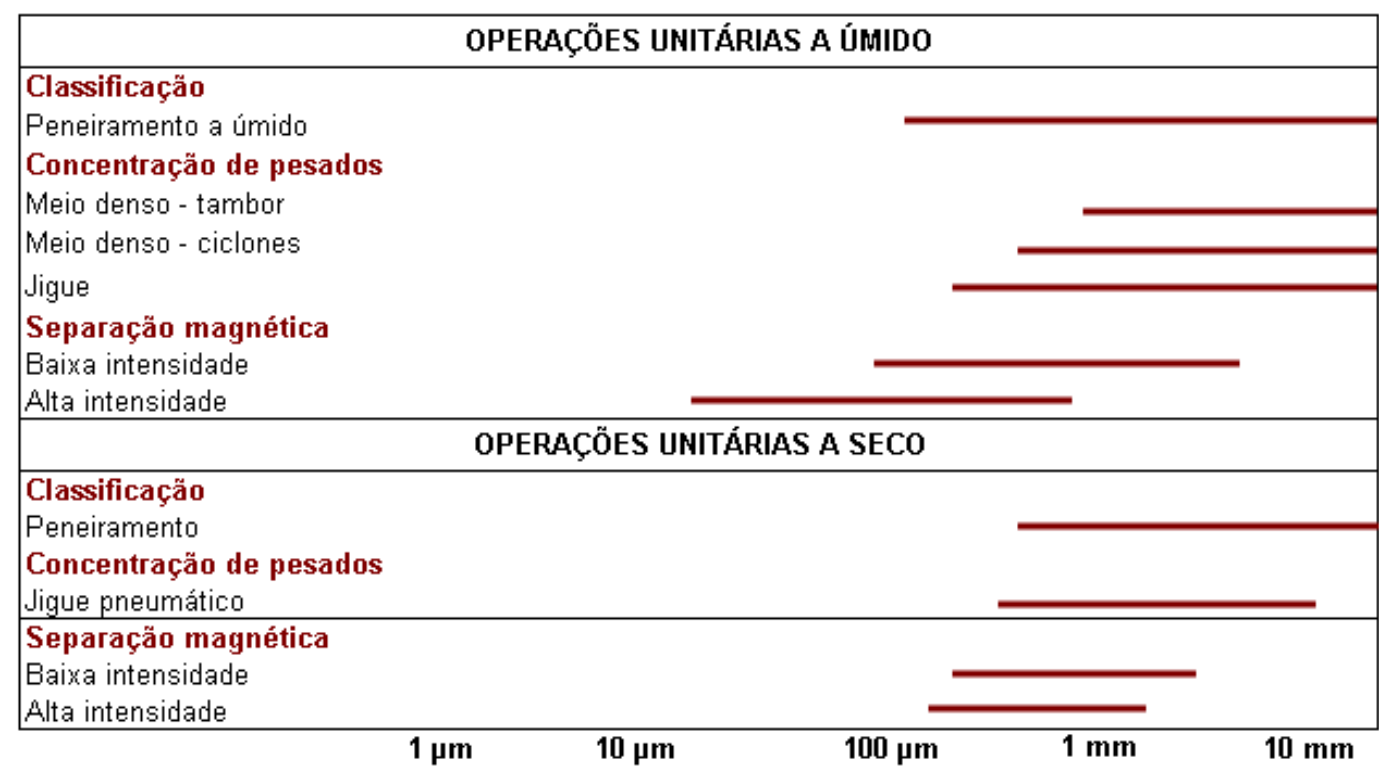

Figura 2.21 - Equipamentos de possível uso em RCD (JUNGMANN; QUINDT, 1999, JONES, 1987, modificado)

No caso da implantação de uma usina através de métodos densitários, nenhuma das operações unitárias conseguiria abranger toda a faixa granulométrica dos agregados de RCD britados; a mais adequada é a jigagem (JUNGMANN; QUINDT, 1999), que abrange o intervalo granulométrico dos agregados graúdos e uma significativa parcela do intervalo de agregados miúdos, além de apresentar baixo custo relativo; o cone Reichert e/ou espirais podem ser aplicados para os agregados miúdos e finos. No entanto, cumpre destacar que qualquer processo de concentração gravítica tem duas grandes desvantagens: recirculação de grandes volumes de água, coleta e secagem de lamas, em contrapartida apresentam baixos custos de investimento e operacional.

\subsubsection{Contextos nacional e internacional}

O material processado nas usinas é geralmente analisado visualmente para avaliação do teor da fração não mineral, entretanto essa análise pode ser enganosa à medida que a porção superior da caçamba não necessariamente corresponde ao seu total. Uma alternativa possível para contornar esse problema seria a pesagem das caçambas (ÂNGULO et al, 2005) e posterior comparação com a massa que cada caçamba deveria ter, aproximadamente, considerando-se uma densidade média e volume fixo 
da caçamba. Em Salzburg, Áustria, emprega-se uma câmera digital para classificação do RCD em mineral ou não-mineral (Figura 2.22), entretanto este critério só permite avaliação da porção superficial das caçambas.

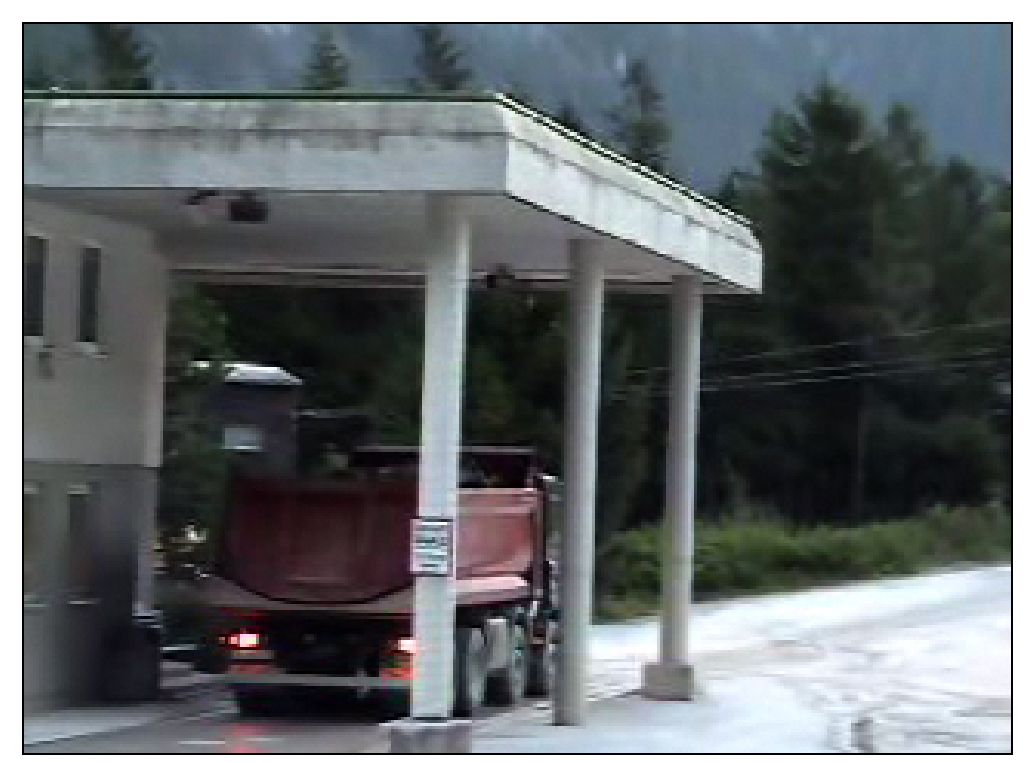

Figura 2.22 - Classificação do RCD em mineral e não-mineral através de câmera digital Fonte: Sérgio C. Ângulo

A seleção manual (catação) é a etapa subseqüente à classificação visual e tem por objetivo a remoção da fração não-mineral grosseira (maior que 4,8 mm). Baseia-se em diferenças de cor, forma ou textura das partículas (CHAVES, 1996; HENDRIKS, 2000); pode ser realizada antes e/ou após a britagem e, normalmente, sobre transportadores de correia. Entretanto, não pode ser considerada uma ferramenta de controle de qualidade acurada; em países de tecnologia avançada no usina de RCD, como, por exemplo, a Holanda, o procedimento pode ser substituído por processos industriais conforme apresentado na Figura 2.23. 


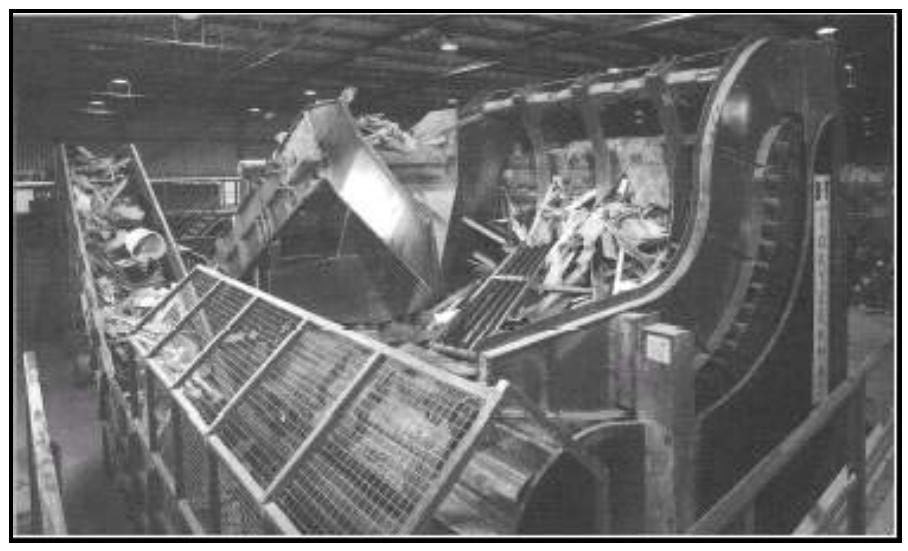

Figura 2.23 - Separação da fração não-mineral do RCD na alimentação de usinas de reciclagem da Holanda Fonte: Hendriks, 2000; Kowalczyk et al., 2002; Thole, 2002

Na reciclagem da fração mineral de RCD emprega-se apenas a britagem na etapa de cominuição. Geralmente, no Brasil emprega-se apenas britagem primária através de britador de impacto; na Europa são mais freqüentes usinas com dois estágios de britagem, conjugando britadores de mandíbulas e impacto como primário-secundário ou o contrário, embora existam usinas que empregam apenas a britagem primária ${ }^{11}$ (HENDRIKS, 2000). A cominuição secundária é empregada para otimizar a granulometria dos agregados de RCD reciclados para uso em concretos (GRUBL; RUHL, 1998 e ÂNGULO et al., 2003), além disso, pode ser utilizada para otimizar o balanço de massa dos produtos. No Brasil, por exemplo, a fração superior a $25,4 \mathrm{~mm}$ não é usualmente utilizada em concretos e pode representar até $45 \%$ da massa dos agregados (ULSEN et al., 2004).

Normalmente os britadores empregados são de impacto ou mandíbulas; os de mandíbulas são tidos como melhores para produção de agregados para concretos quando associados a uma etapa de britagem secundária, no entanto são bastante sensíveis à presença de resíduos de madeira e metálicos. Os britadores de impacto são menos suscetíveis a tais presenças e possuem maior capacidade de redução; são considerados melhores equipamentos para produção de agregados para uso em pavimentação (ITEC, 1995c).

\footnotetext{
${ }^{11}$ Empresa holandesa Van Bentum Recycling Centrale, em Utrecht.
} 
$\mathrm{Na}$ Alemanha existem estudos que visam a separação entre as rochas naturais e a argamassas presentes nos agregados de concretos reciclados através da utilização de britagem por impacto devido o processo de fraturas intergranulares (TOMAS et al., 1997; TOMAS et al., 1999), de modo que a fração representada pelas rochas naturais com granulometria compreendida entre 2 a $16 \mathrm{~mm}$ apresente qualidade semelhante ao agregado natural, especialmente interessante para o emprego em concretos. Para a mesma finalidade comprovou-se também a eficiência de utilização de processos térmicos a $650^{\circ} \mathrm{C}$, mas a um elevado custo.

Paralelamente investiga-se a liberação das rochas e argamassa através da cominuição por descarga elétrica (MULLER; LINSZ, 2004). Nesse estudo, outros métodos de liberação são discutidos, empregando cominuição combinada com abrasão através do emprego de moinhos de eixos excêntricos.

Na usina de Salzburg, Áustria, a etapa de britagem é realizada em dois estágios com a inclusão de separação magnética entre estas. A britagem primária é efetuada em britador de impacto, com a vantagem de processar armaduras das peças de concreto armado; em seguida há uma etapa de separação magnética na qual também se utiliza catação para remoção de material não-mineral de grandes dimensões (Figura 2.24); o resíduo livre de material metálico é rebritado em britador de mandíbulas para redução e adequação granulométrica para alimentação da etapa posterior que é a jigagem.

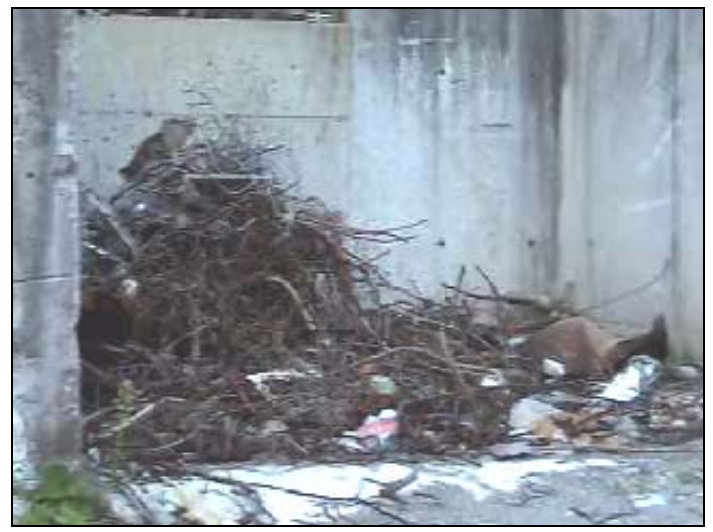

(a)

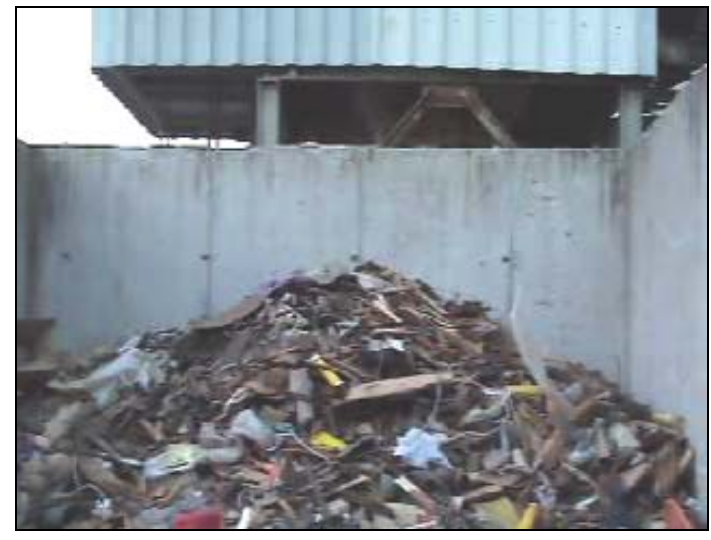

(b)

Figura 2.24 - Fração metálica obtida por separação magnética (a) e catação (b) em Salzburg. Fonte: Sérgio C. Ângulo 
Outra alternativa para separar a fração não-mineral do RCD é a utilização de classificadores pneumáticos (MOSKALA; SCHNEIDER-KUHN, 1997; WILSON, 1996; HANISCH, 1998; HENDRIKS, 2000; KOHLER; KURKOWSKI, 2000), os quais são instalados nos pontos de transferência entre transportadores de correia (HANISCH, 1998). A corrente de ar ascendente produzida transporta partículas leves de papel, plásticos, madeiras e outros contaminantes dos agregados de RCD reciclados (Figura 2.25).

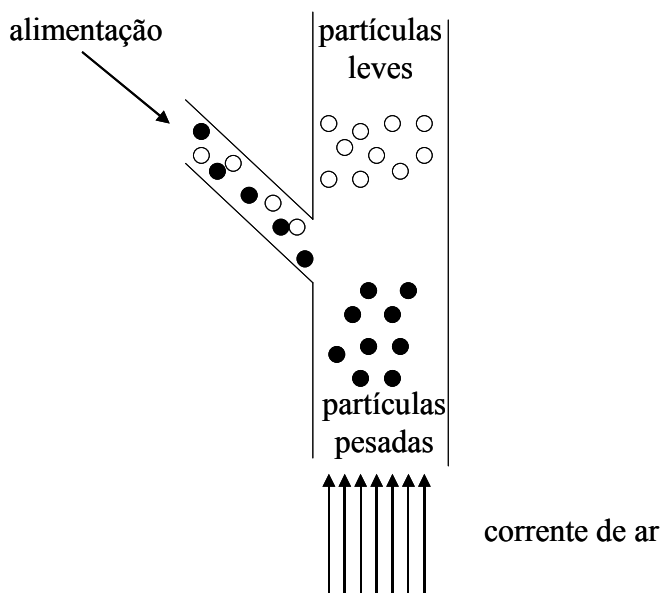

Figura 2.25 - Esquema do funcionamento dos classificadores pneumáticos utilizados na reciclagem da fração mineral do RCD (HENDRIKS, 2000)

Além dos contaminantes plásticos, madeira e outros removidos por catação, há ainda a fração metálica usualmente separada da fração mineral através de separadores magnéticos de baixa intensidade antes e/ou após a etapa de britagem (WILSON, 1996; HANISCH, 1998); no Brasil, é realizada por seleção manual antes da britagem e por separadores magnéticos após a etapa de cominuição.

A etapa subseqüente é a classificação por tamanho. As usinas brasileiras empregam normalmente peneiramento a seco através de peneiras vibratórias inclinadas, com até 3 telas e aberturas normalmente superiores a $4,8 \mathrm{~mm}$, com exceção da usina situada na cidade de Socorro, SP, que emprega um corte na fração 1,2 $\mathrm{mm}$ para direcionar a reciclagem dos finos para uso em argamassas. A fração acima de $20 \mathrm{~mm}$ é normalmente utilizada para produção de pedra-rachão e comercializada como 
material de enchimento; a fração entre 12,7 e 9,5 mm é utilizada para produção de dois diferentes tipos de britas recicladas.

$\mathrm{Na}$ Holanda e na Alemanha utiliza-se uma etapa de escalpe em telas de 8 a $10 \mathrm{~mm}$ antes da cominuição para remoção da fração miúda contaminada com hidrocarbonetos e dioxinas dos resíduos de demolição (WILSON, 1996; HENDRIKS, 2000; KOHLER; PENZEL, 1997); na Bélgica não se adota tal prática (ANCIA et al., 1999). Também é descrito por Muller (2003) o peneiramento em 4 frações $(45,32,16$ e 8 mm).

A fração fina $(<0,075 \mathrm{~mm})$ não removida interfere negativamente na qualidade dos agregados reciclados de RCD pela presença de solo aderido à fração mineral, que pode ser removida através de classificadores hidráulicos (WILSON (1996), HANISCH (1998) e HENDRIKS (2000). De forma análoga aos classificadores pneumáticos, as partículas circulam em direção contrária, porém nesse caso o meio fluido é água. Os equipamentos usuais utilizam até $120 \mathrm{~m}^{3} / \mathrm{h}$ de água para o usina de 60 a 100 t/h de sólidos (HANISCH, 1998). Outra possibilidade descrita por HANISCH (1998) é a utilização de classificador espiral, que tem a vantagem de utilizar uma quantidade menor de água, em torno de $30 \mathrm{~m}^{3} / \mathrm{h}$ para processar $80 \mathrm{t} / \mathrm{h}$ de sólidos, a um custo mais acessível.

Em um projeto conjunto entre a Universidade de Aachen - Alemanha, e Delft Holanda, constatou-se a possibilidade de separação da fração cerâmica das demais, bem como material não mineral através da utilização de equipamento de separação óptica segundo o critério cor (Figura 2.26). 

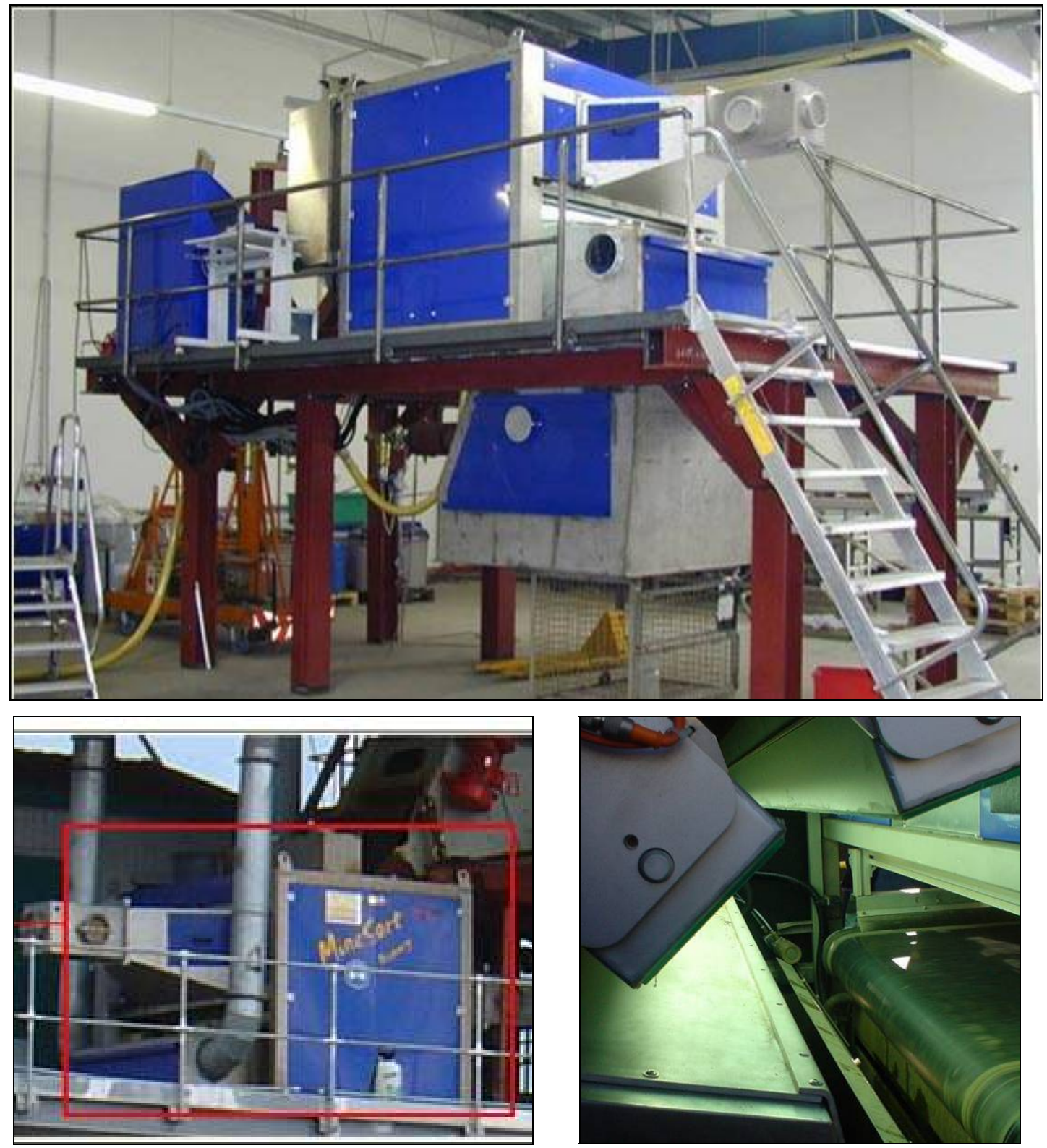

Figura 2.26 - Equipamento de separação óptica (Scan\&Sort) 


\subsubsection{Concentração gravítica dos agregados de $\mathrm{RCD}$ reciclados}

Assim como em processos de beneficiamento mineral, podem-se utilizar equipamentos de concentração gravítica para a reciclagem de RCD. Os jigues são particularmente interessantes do ponto de vista econômico; operam em densidades de corte entre 1,6 e $2,5 \mathrm{~g} / \mathrm{cm}^{3}$, sendo que os cortes ótimos são entre 1,6 e 2,1 g/ $/ \mathrm{cm}^{3}$ (ANCIA et al., 1999; MOSKALA; SCHNEIDER-KUHN, 1997; BREUER et al., 1997; HANISCH, 1998; XING et al., 2002; MESTERS; KURKOWSKI, 1997; KOHLER; KURKOWSKI, 2000).

O jigue utilizado na usina de Salzburg, Áustria é fabricado pela empresa All Mineral, localizada em Duisburg, Alemanha. A Figura 2.27 ilustra o produto da separação em densidade de corte entre 1,7 e $1,9 \mathrm{~g} / \mathrm{cm}^{3}$, em que se concentra de 5 a $20 \%$ do RCD total; visualmente a composição é predominantemente não-mineral com possível presença de material mineral leve, como blocos de concreto celular.

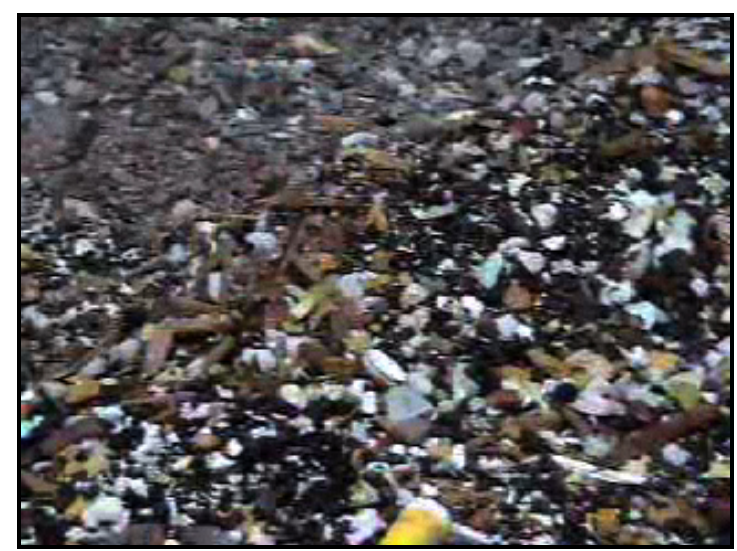

Figura 2.27 - Fração não mineral (lignita, isopor, madeira) separada por jigagem (Salzburg, Áustria). Fonte: Sérgio C. Ângulo

O produto pesado da jigagem é então classificado em peneiras de 4, 16 e $32 \mathrm{~mm}$, sendo areia, brita tipo I e brita tipo II, respectivamente (Figura 2.28). 


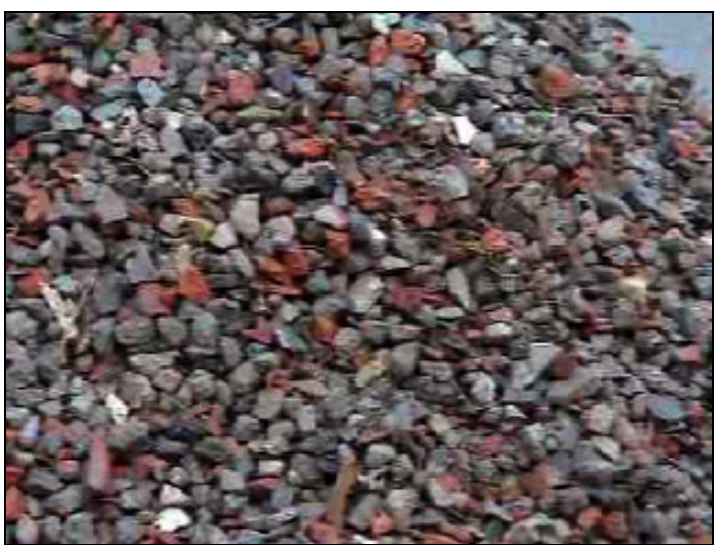

(a)

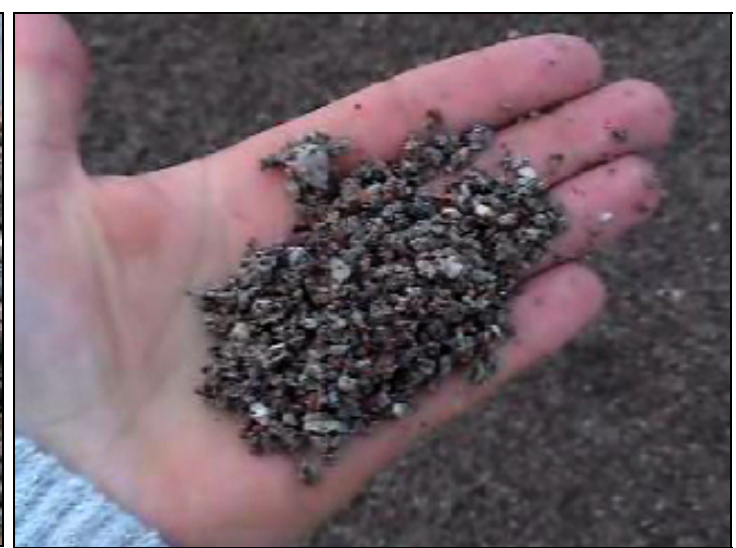

(b)

Figura 2.28 - Produtos de RCD reciclado da usina de Salzburg: (a) agregado graúdo (4-16 mm), (b) areia. Fonte: Sérgio C. Ângulo

A lama resultante do processo (Figura 2.29) pode representar até $15 \%$ da massa total do resíduo processado e é utilizada como camada de proteção em aterros sanitários.

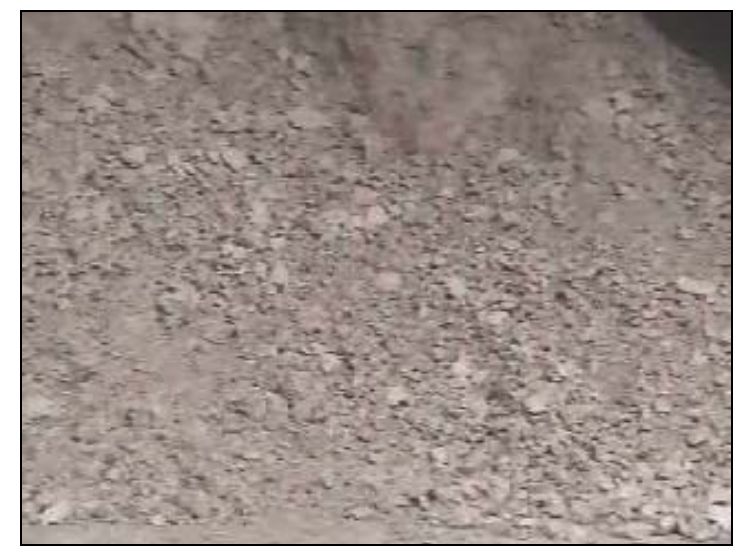

Figura 2.29 - Lama resultante da jigagem de RCD da usina de Salzburg. Fonte: Sérgio C. Ângulo

A Figura 2.30 mostra o jigue empregado na usina de Salzburg (Alljig). 


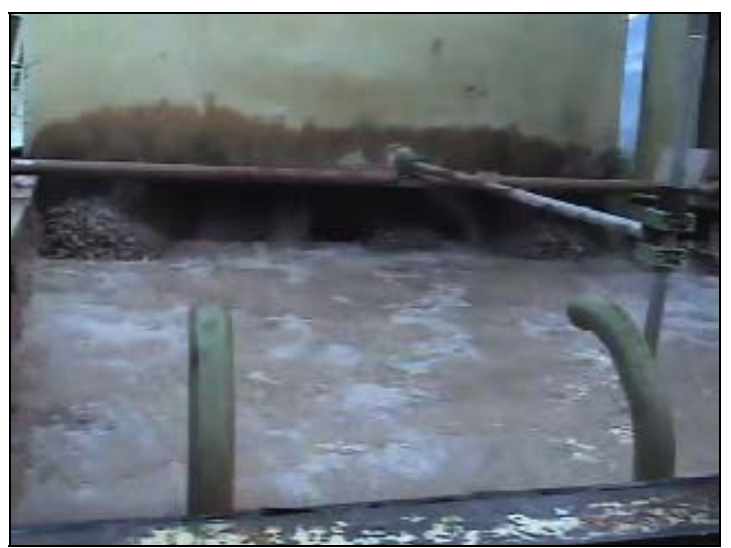

(a)

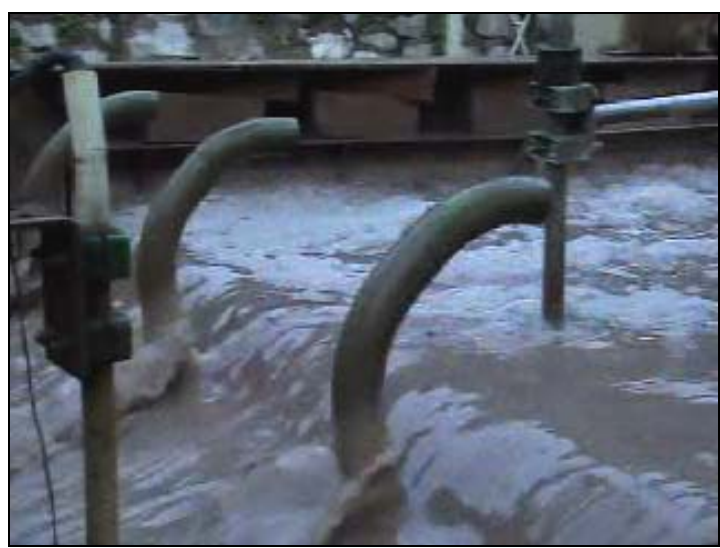

(b)

Figura 2.30 - Vista frontal (a) e lateral (b) do leito pulsante do jigue (Salzburg, Áustria). Fonte: Sérgio C. Ângulo

A empresa All Mineral fabrica jigues em três diferentes configurações:

- Alljig (Figura 2.31) - separação em meio fluido (água) através do sistema de pulsão de água. Opera com material de 2 a $32 \mathrm{~mm}$, sendo, portanto, mais utilizado na fração graúda ( $>4,8 \mathrm{~mm})$. Apresenta como vantagens o baixo custo de manutenção e alta eficiência de separação, entretanto, a operação requer um elevado consumo de água e uma etapa posterior de deslamagem.

- Allflux (Figura 2.32) - empregado preferencialmente para partículas de dimensões inferiores a $4 \mathrm{~mm}$; gera três produtos: leves, pesados e lamas $(<75$ $\mu \mathrm{m})$.

- Allair (Figura 2.33) - este equipamento realiza jigagem a seco; é utilizado em usinas de carvão, mas pode ser utilizados para separação da fração leve orgânica presente nos RCD. Dessa forma, reduzem-se os custos com recirculação de água, espessamento e deslamagem. 


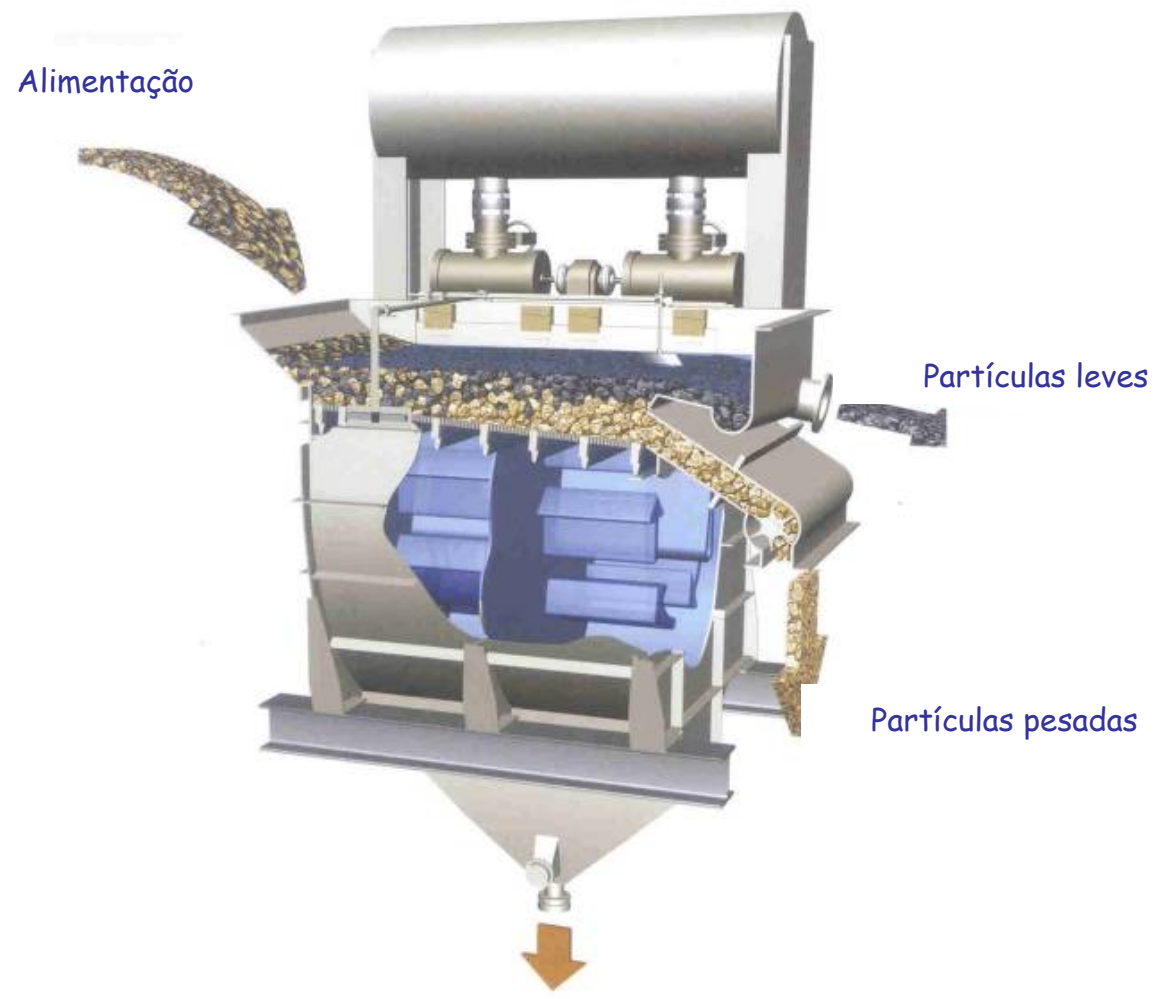

Figura 2.31 - Desenho esquemático sobre o funcionamento do “Alljig” (Fonte: www.allmineral.com, modificada)

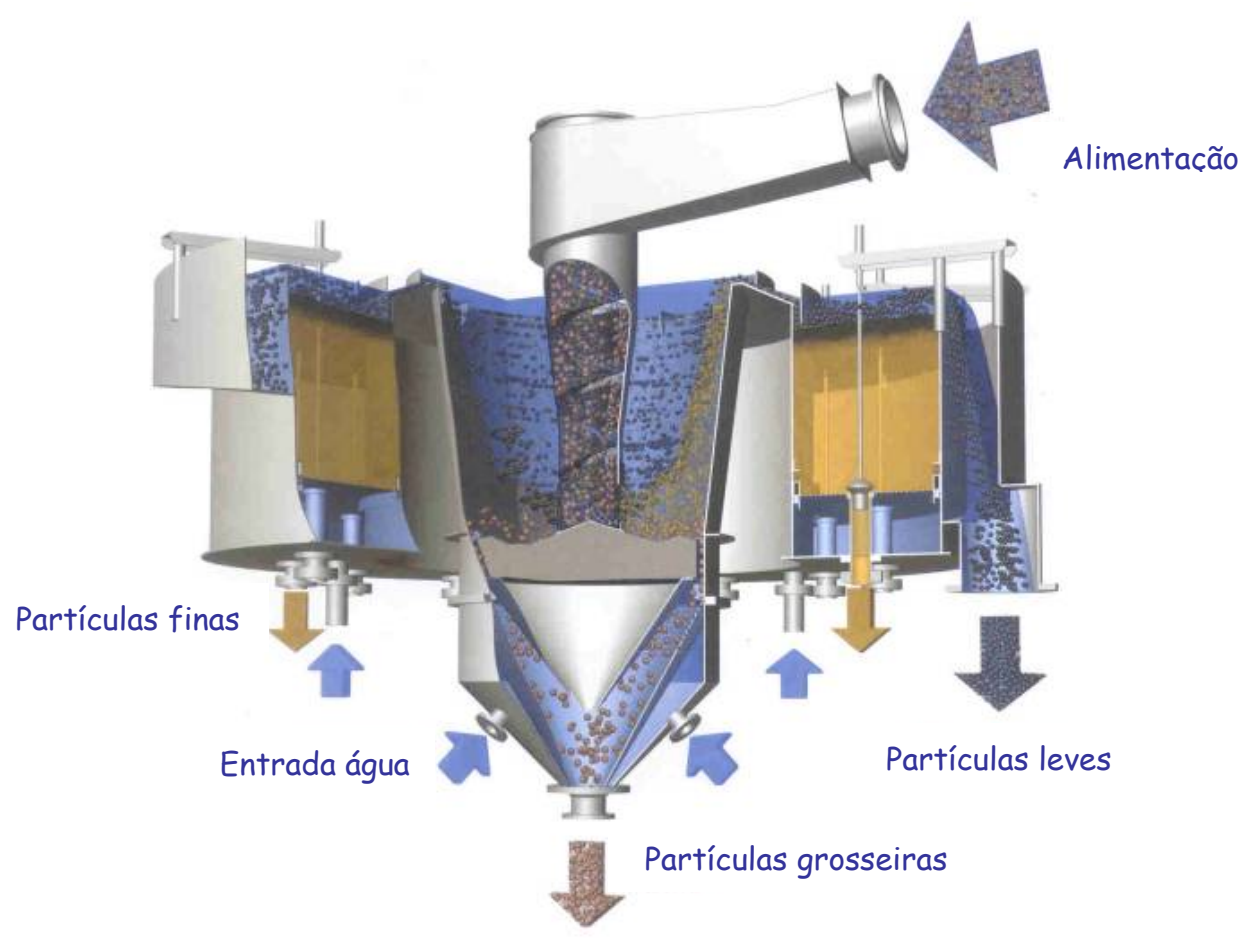

Figura 2.32 - Desenho esquemático sobre o funcionamento do "Allflux" (Fonte: www.allmineral.com, modificada) 


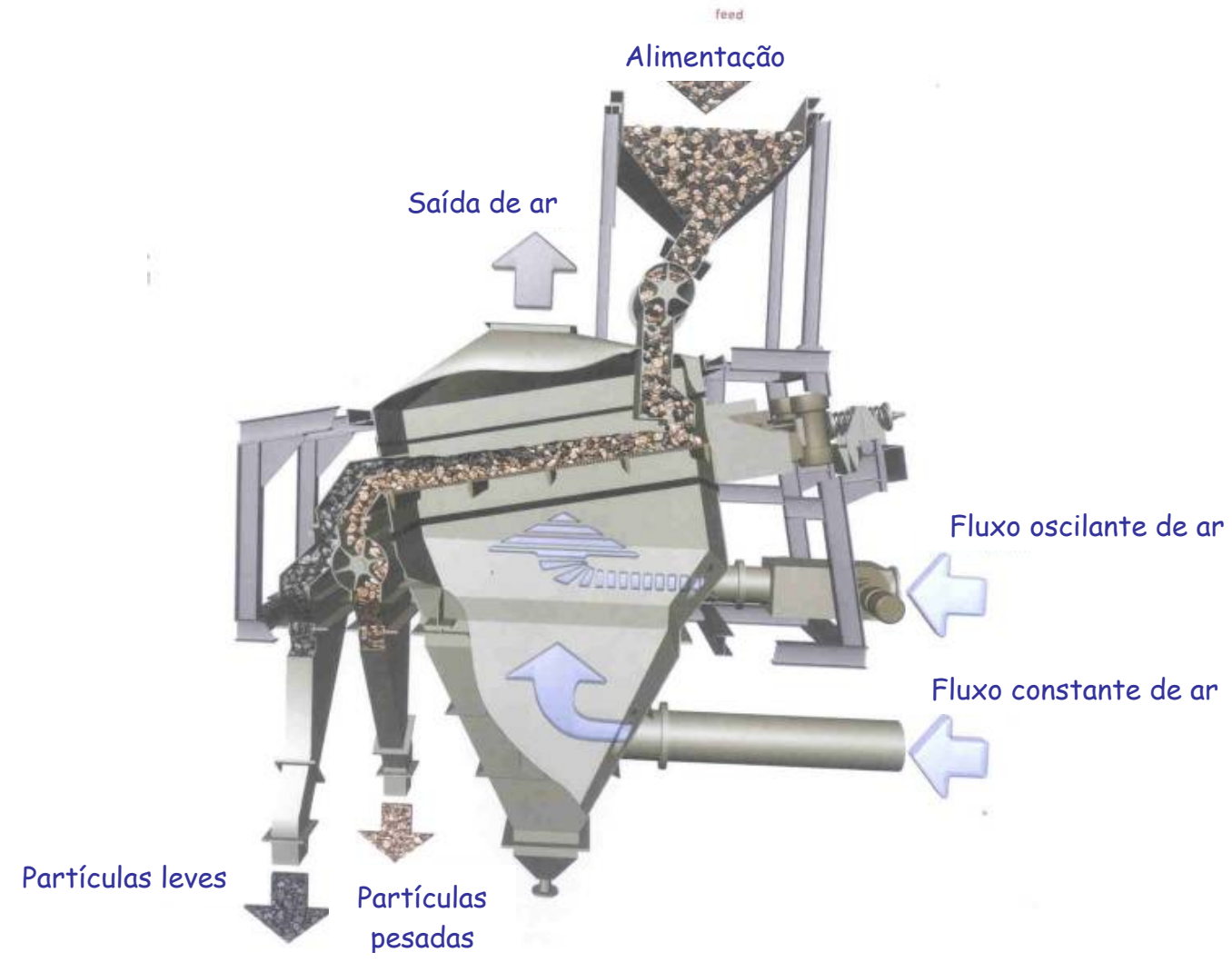

Figura 2.33 - Desenho esquemático sobre o funcionamento do “Allair” (Fonte: www.allmineral.com, modificada)

A jigagem, como os outros equipamentos de concentração gravítica, apresentam elevado consumo de água (que pode ser utilizada em circuito fechado), entretanto as vantagens são inúmeras, citam-se:

- Redução dos teores da fração não-mineral nos agregados de RCD reciclados a menos de 1\% (JUNGMANN et al., 1997; JUNGMANN; QUINDT, 1999; KOHLER; KURKOWSKI, 2000) permitindo atender exigências legislativas da reciclagem e requisitos de qualidade para uso em concretos.

- Redução da emissão de material particulado no usina (JUNGMANN et al., 1997; JUNGMANN; QUINDT, 1999; KOHLER; KURKOWSKI, 2000). 
- Redução do teor de finos $(<0,075 \mathrm{~mm})$ presentes nos agregados (JUNGMANN et al., 1997; JUNGMANN; QUINDT, 1999; KOHLER; KURKOWSKI, 2000).

- Aumento da massa específica aparente dos agregados, especialmente interessante para uso em concretos.

- Baixo custo de aquisição e operacional, existindo modelos para diversas faixas de capacidade (GAUDIN, 1932).

No Brasil, a melhoria na qualidade do agregado reciclado separado por processos gravíticos é confirmada por Carrijo (2005). A autora concluiu que concretos obtidos a partir de agregados graúdos de RCD reciclados separados em intervalos de densidade apresentam resistência mecânica crescente com a faixa de densidade para o mesmo consumo de cimento Os agregados de densidade superior a $2,2 \mathrm{~g} / \mathrm{cm}^{3}$ possibilita a produção de concretos com resistências semelhantes às dos concretos de agregados naturais, podendo ser empregados em concretos estruturais convencionais com resistência mecânica superior a $20 \mathrm{MPa}$.

\subsubsection{Usinas de reciclagem}

No Brasil, existem aproximadamente 12 usinas de reciclagem da fração mineral de RCD com escala de produção inferior a 100 t/dia (ÂNGULO et al., 2005). As usinas são geralmente estacionárias e constituídas pelas seguintes operações: catação, cominuição (britagem) e separação granulométrica, algumas apresentam separadores magnéticos, transportadores de correia e sistema de abatimento de pó (ANGULO et al., 2002b; ANGULO et al., 2003b).

As operações unitárias bem como os equipamentos encontrados em algumas usinas de reciclagem nacionais são descritas na Tabela 2.6. 
Tabela 2.6 - Operações unitárias e equipamentos encontrados em algumas usinas fixas nacionais de reciclagem da fração mineral do RCD (ÂNGULO et al., 2005, modificado)

\begin{tabular}{|c|c|c|c|c|}
\hline Usinas de reciclagem & Cominuição & Peneiramento & Concentração & Op. auxiliares \\
\hline Santo André, SP ${ }^{1}$ & $\begin{array}{l}\text { Impacto } \\
(10+/ h)\end{array}$ & $12,7 \mathrm{~mm}$ & Catação (AC) & $1 \mathrm{TC}$ \\
\hline $\begin{array}{l}\text { São Paulo (Itaquera), } \\
\text { SP }\end{array}$ & $\begin{array}{l}\text { Impacto } \\
(100+/ h)\end{array}$ & 40,20 e $4,8 \mathrm{~mm}$ & $\begin{array}{l}\text { Catação } \\
(A C / P C) \\
\text { Sep. Magnética }\end{array}$ & $2 T C$ \\
\hline Vinhedo, SP & $\begin{array}{l}\text { Mandíbulas } \\
(8 \mathrm{t} / \mathrm{h})\end{array}$ & $12,7,9,5$ e $4,8 \mathrm{~mm}$ & Catação (AC) & $\begin{array}{l}1 \mathrm{TC} \\
1 \mathrm{AP}\end{array}$ \\
\hline Ribeirão Preto, SP ${ }^{2}$ & $\begin{array}{l}\text { Impacto } \\
(30+/ h)\end{array}$ & $\mathrm{Nd}$ & $\begin{array}{l}\text { Catação ( } A C \text { ) } \\
\text { Sep. magnética }\end{array}$ & $\begin{array}{l}1 \mathrm{TC} \\
1 \mathrm{AP}\end{array}$ \\
\hline Socorro, SP ${ }^{3}$ & $\begin{array}{l}\text { Mandíbulas } \\
(2,5 \mathrm{t} / \mathrm{h}) \\
\text { Moinho de } \\
\text { impacto }\end{array}$ & $20,4,8$ e $1,2 \mathrm{~mm}$ & $\begin{array}{l}\text { Catação }(A C) \\
\text { Sep. magnética }\end{array}$ & $\begin{array}{l}\text { Classificador à } \\
\text { úmido }\end{array}$ \\
\hline $\begin{array}{l}\text { Piracicaba, SP } \\
\text { São Paulo }\end{array}$ & Mandíbulas & 12,$7 ; 9,5$ e $4,8 \mathrm{~mm}$ & $\begin{array}{l}\text { Catação }(A C) \\
\text { Sep. magnética }\end{array}$ & $2 T C$ \\
\hline Campinas, SP & $\begin{array}{l}\text { Impacto } \\
(80 \mathrm{t} / \mathrm{h})\end{array}$ & $\begin{array}{l}50,25,4,12,7 \mathrm{e} \\
4,8 \mathrm{~mm}\end{array}$ & $\begin{array}{l}\text { Catação ( } A C \text { ) } \\
\text { Sep. magnética }\end{array}$ & $2 T C$ \\
\hline Londrina, PR & $\begin{array}{l}\text { Impacto } \\
\text { Moinho de } \\
\text { martelos }\end{array}$ & $4,8 \mathrm{~mm}$ & Catação (AC) & $1 \mathrm{TC}$ \\
\hline $\begin{array}{l}\text { Belo Horizonte } \\
\text { (Pampulha), MG }\end{array}$ & $\begin{array}{l}\text { Impacto } \\
(30+/ h)\end{array}$ & Peneiras & Catação $(A C)^{4}$ & $\begin{array}{l}1 \mathrm{AP} \\
1 \mathrm{TC} \\
\end{array}$ \\
\hline $\begin{array}{l}\text { Belo Horizonte } \\
\text { (Estoril), } M G^{5}\end{array}$ & $\begin{array}{l}\text { Impacto } \\
(25+/ h)\end{array}$ & $\mathrm{Nd}$ & Catação (AC) & $1 \mathrm{TC}$ \\
\hline Macaé, RJ & $\begin{array}{l}\text { Impacto } \\
(6-8+/ h)\end{array}$ & $\mathrm{Nd}$ & $\begin{array}{l}\text { Catação ( } A C \text { ) } \\
\text { Sep. magnética }\end{array}$ & $1 \mathrm{TC}$ \\
\hline
\end{tabular}

1 Usina piloto. Atualmente desativada; 2 Conforme ZORDAN (1997); 3 Fonte: L.MIRANDA(2000); 4 Realizada em pilhas horizontais; 5 Conforme PINTO (1999)

nd significa não-detectado; AC significa "antes da cominuição" e PC significa "após a cominuição"; TC significa "transportadores de correia" e AP significa "abatedores de poeira"

As usinas nacionais, com exceção da situada em Socorro, operam em via seca. As operações unitárias das usinas de reciclagem européias, que operam em via seca, assemelham-se às brasileiras, embora as operações de concentração via úmida tem tido grande propulsão em países de reciclagem menos incipiente, como Holanda e Alemanha, possibilitando a obtenção de agregados de melhor qualidade, com teores reduzidos de fração não-mineral e finos (menor que $0,075 \mathrm{~mm}$ ) e maior massa específica aparente (JUNGMANN, 1997; QUINDT, 1999; KOHLER; KURKOWSKI, 2000). 
As operações unitárias e equipamentos empregados em algumas usinas de reciclagem européias são sumariados na Tabela 2.7 .

Tabela 2.7 - Operações unitárias e equipamentos de algumas usinas fixas de reciclagem da fração mineral do RCD (ÂNGULO, et al, 2005 - modificado)

\begin{tabular}{|l|l|l|l|l|}
\hline \multicolumn{1}{|c|}{ Usinas reciclagem } & \multicolumn{1}{|c|}{ Britagem } & \multicolumn{1}{|c|}{ Peneiramento } & \multicolumn{1}{c|}{ Concentração } & \multicolumn{1}{c|}{ Op. auxiliares } \\
\hline Alemanha & $\begin{array}{l}\text { Mandíbulas (prim.) } \\
\text { Impacto (séc.) }\end{array}$ & $\begin{array}{l}\text { Escalpe 12 e 120 mm } \\
\text { Peneiras 45, 32, 16, } \\
8 \mathrm{~mm}\end{array}$ & $\begin{array}{l}\text { Catação (AB e DB) } \\
\text { Sep. Magnética (2) } \\
\text { "Scrubber" }\end{array}$ & TC (vários) \\
\hline $\begin{array}{l}\text { "Sistema Hazemag" } \\
\text { Holanda }\end{array}$ & Impacto & $80,40,10 \mathrm{~mm}$ & $\begin{array}{l}\text { Catação (AB) } \\
\text { Sep. pneumática }\end{array}$ & TC (8) \\
\hline $\begin{array}{l}\text { Salzburg } \\
\text { Áustria }\end{array}$ & Impacto & 32,16 e $4 \mathrm{~mm}$ & $\begin{array}{l}\text { Catação (PC) } \\
\text { Jigue }\end{array}$ & $\begin{array}{l}\text { Rec. de água } \\
\text { Desaguador } \\
\text { Trat das lamas }\end{array}$ \\
\hline
\end{tabular}

AB significa "antes da britagem" e PC significa "após a britagem".

TC significa "transportadores de correia" e AP significa "abatedores de poeira"

A Figura 2.34 ilustra o fluxograma de uma usina de reciclagem da fração mineral de RCD na Alemanha (MULLER, 2003).

Embora as operações unitárias sejam semelhantes às nacionais, o circuito da usina é mais aprimorado. Há dois estágios de britagem (mandíbulas e impacto), sendo que a britagem secundária é realizada em circuito fechado com peneira de $45 \mathrm{~mm}$; remoção de contaminantes por catação, tanto antes como após a britagem primária (assim como na usina de Itaquera); escalpe (remoção da fração fina antes da britagem primária); dois estágios de separação magnética em diferentes faixas granulométricas e operação de desagregação do material antes do peneiramento em $8 \mathrm{~mm}$. 


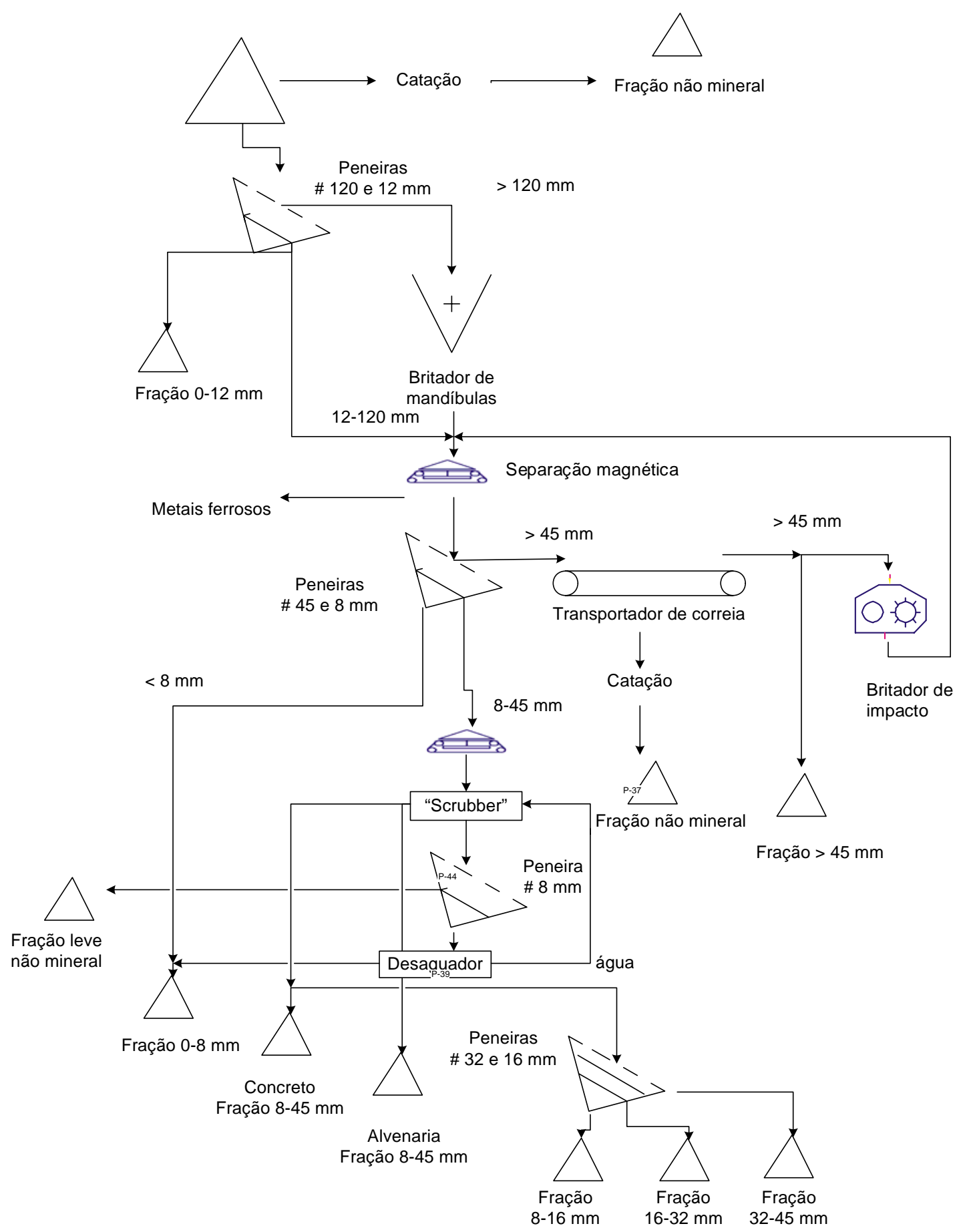

Figura 2.34 - Fluxograma de uma usina de reciclagem da fração mineral do RCD na Alemanha (MULLER, 2003 - adaptado) 
A usina de Salzburg, na Áustria, é um exemplo de usina que emprega jigagem para concentração dos agregados reciclados de RCD. A Figura 2.35 ilustra o fluxograma simplificado de usina da fração mineral do RCD já britada (partículas até $32 \mathrm{~mm}$ ), com a utilização de jigue.

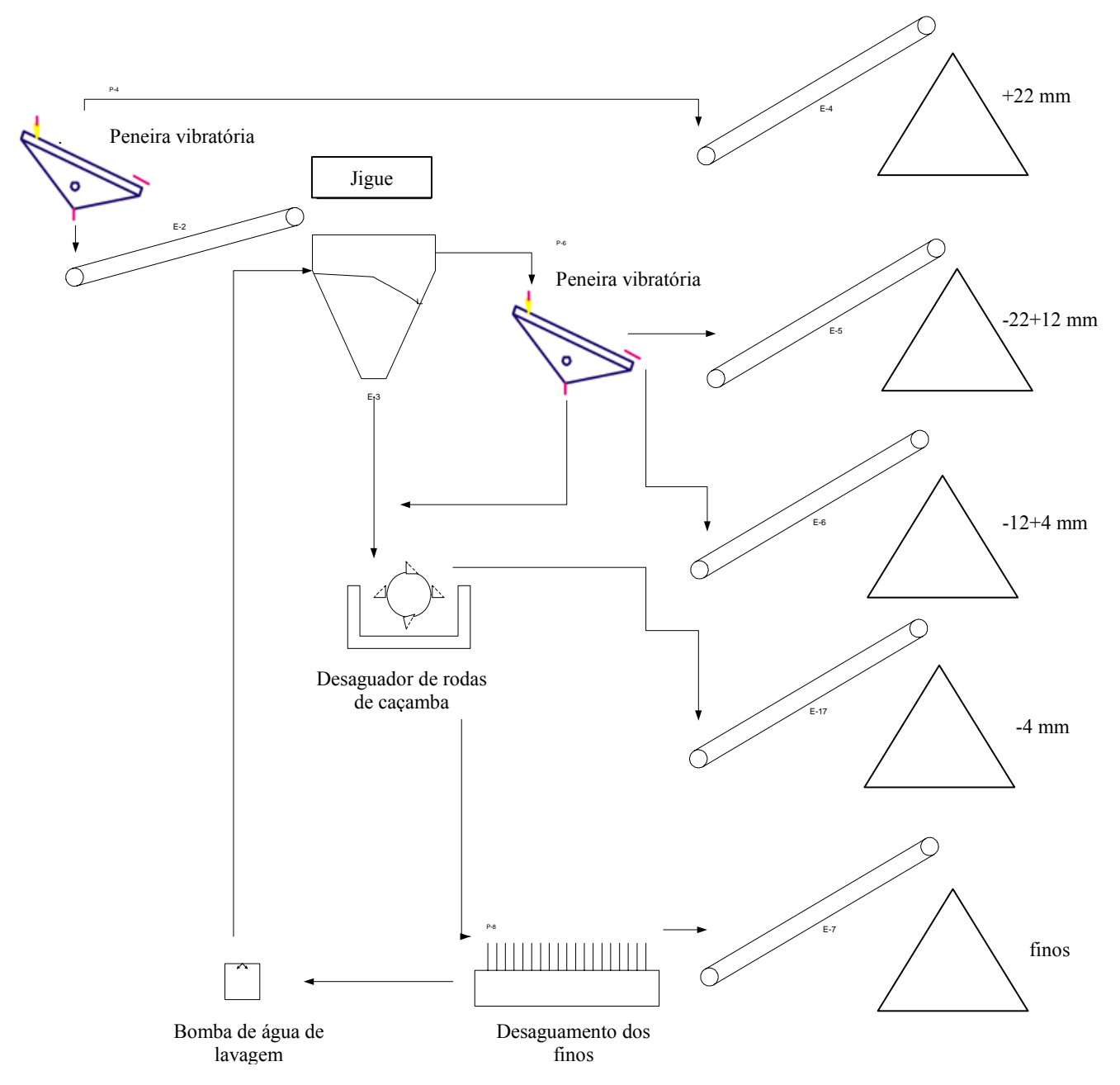

Figura 2.35 - Fluxograma do usina dos agregados de RCD reciclados com utilização de jigue (JUNGMANN, 1997; JUNGMANN; QUINDT, 1999) 


\subsection{USINAS DE RECICLAGEM ESTUDADAS}

\subsubsection{Usina de Itaquera, $S P$}

A usina está localizada na área da antiga pedreira Itaquera, zona leste da cidade de São Paulo. Em 2002, início dos trabalhos de amostragem, a usina contava com 15 funcionários, sendo: onze na etapa de catação, um na britagem, um motorista da retroescavadeira para alimentação do britador, um apontador e um gerente.

A usina tem capacidade de processar 100 t/h de RCD (ÂNGULO et al, 2005), resultando em $800 \mathrm{t}$ /dia, porém recebe e processa apenas $400 \mathrm{t}$ diárias (metade de sua capacidade), das quais cerca de metade é composta por concreto de demolições e metade por blocos, tijolos e argamassas, resíduos mistos de demolições industriais e obras de infra-estrutura urbana.

O material que chega à usina é classificado visualmente em dois tipos de acordo com sua cor: Cinza (ou Tipo I) e Vermelho (ou Tipo II), estes são dispostos em áreas distintas (Figura 2.36) e processados segundo a mesma rota, porém separadamente.

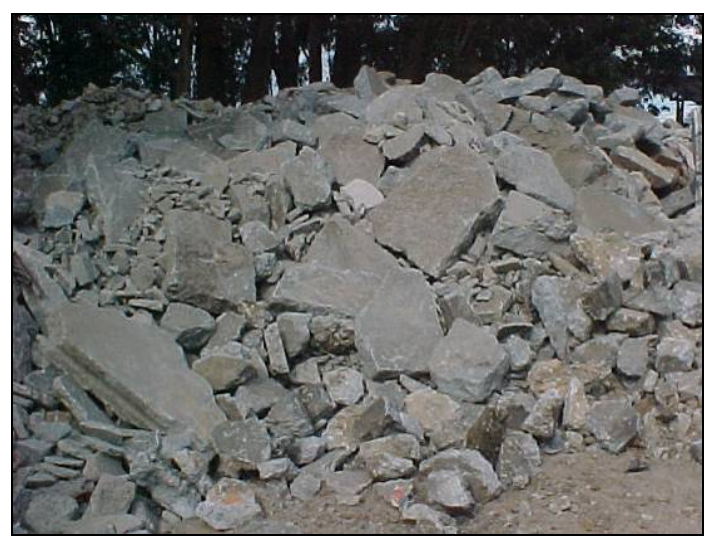

RCD cinza

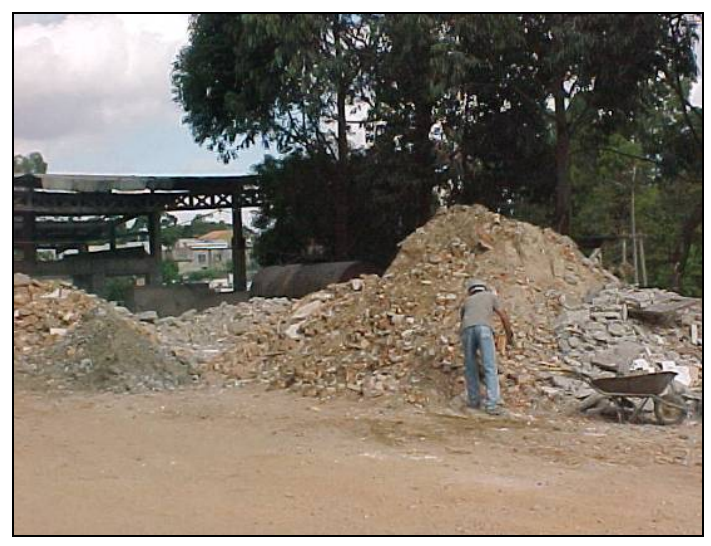

RCD vermelho

Figura 2.36 - Pilhas de RCD na usina de Itaquera (a) RCD cinza, (b) RCD vermelho

As operações unitárias empregadas são:

- Seleção manual: realizada antes (Figura 2.37a) e após a britagem (Figura 2.37b). 


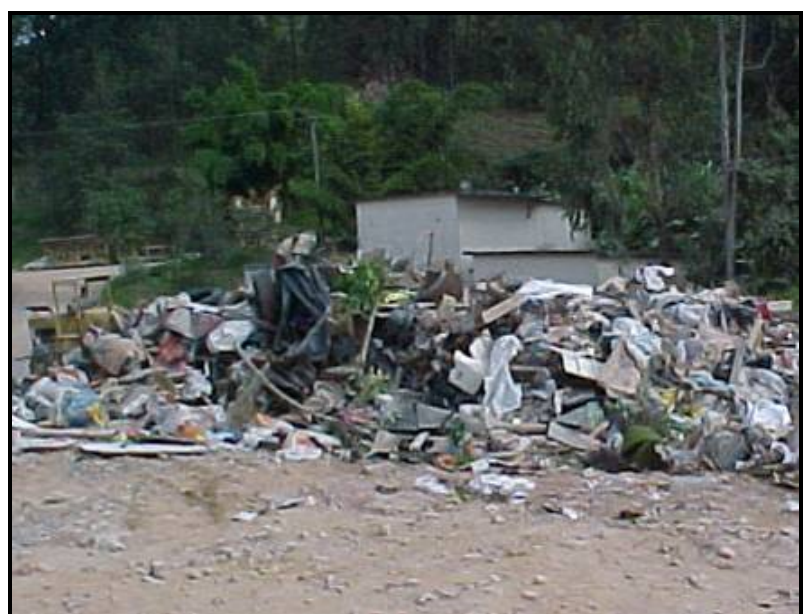

(a)

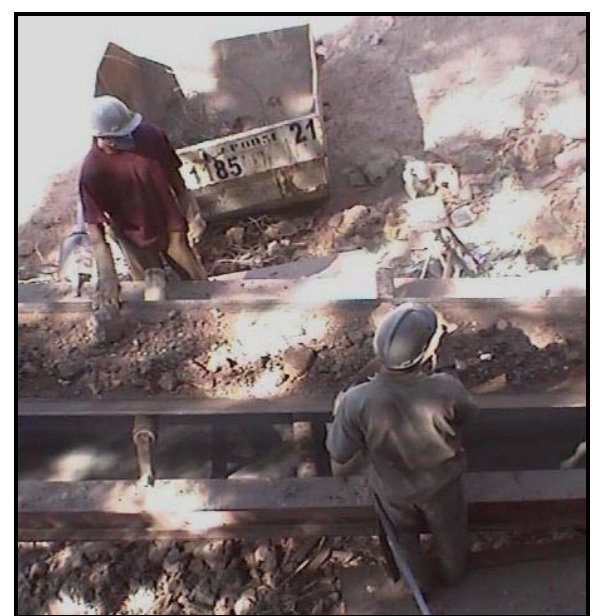

(b)

Figura 2.37 - Seleção manual do RCD na usina de reciclagem de Itaquera; (a) antes e (b) após a britagem

- Cominuição: por britador de impacto (marca NORDBERG) de $100 \mathrm{t} / \mathrm{h}$ de capacidade (Figura 2.38), cuja alimentação é realizada por uma retroescavadeira sem controle de granulometria.
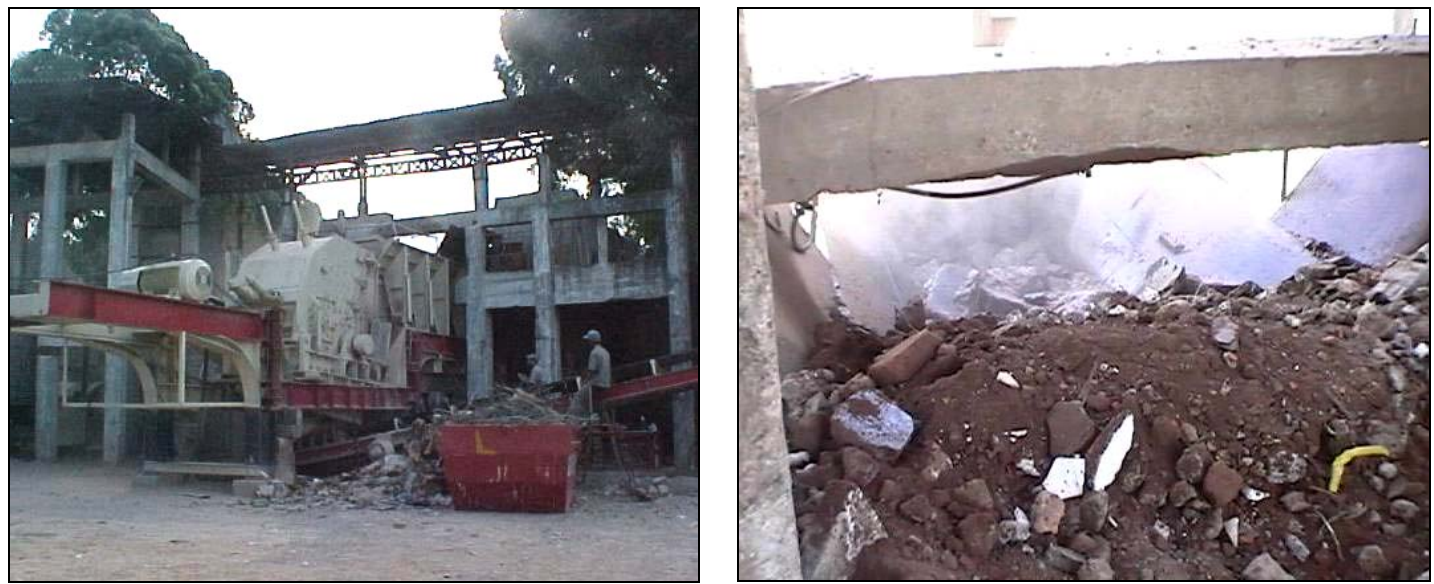

Figura 2.38 - Britador de impacto da usina de Itaquera

- Separação magnética: através de separador magnético de baixa intensidade localizado na correia transportadora após a britagem (Figura 2.39). 


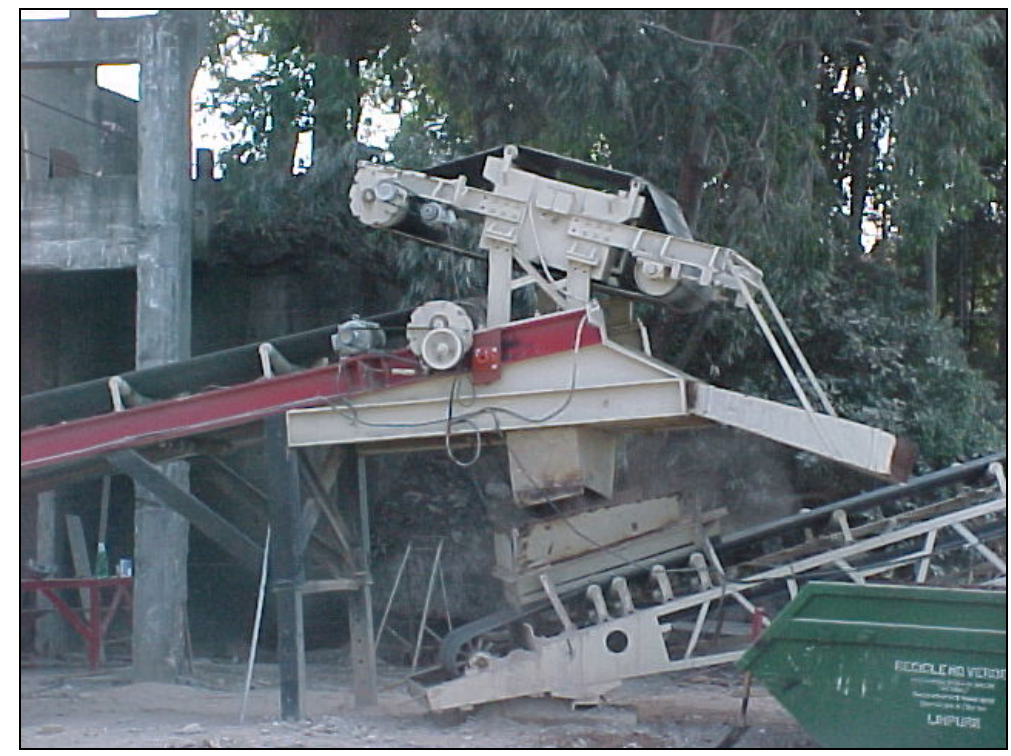

Figura 2.39 - Separação magnética na usina de Itaquera (São Paulo)

- Classificação granulométrica: realizada por peneiramento a seco em peneira inclinada de 3 decks, com aberturas de 40, 20 e 4,8 mm (Figura 2.40).
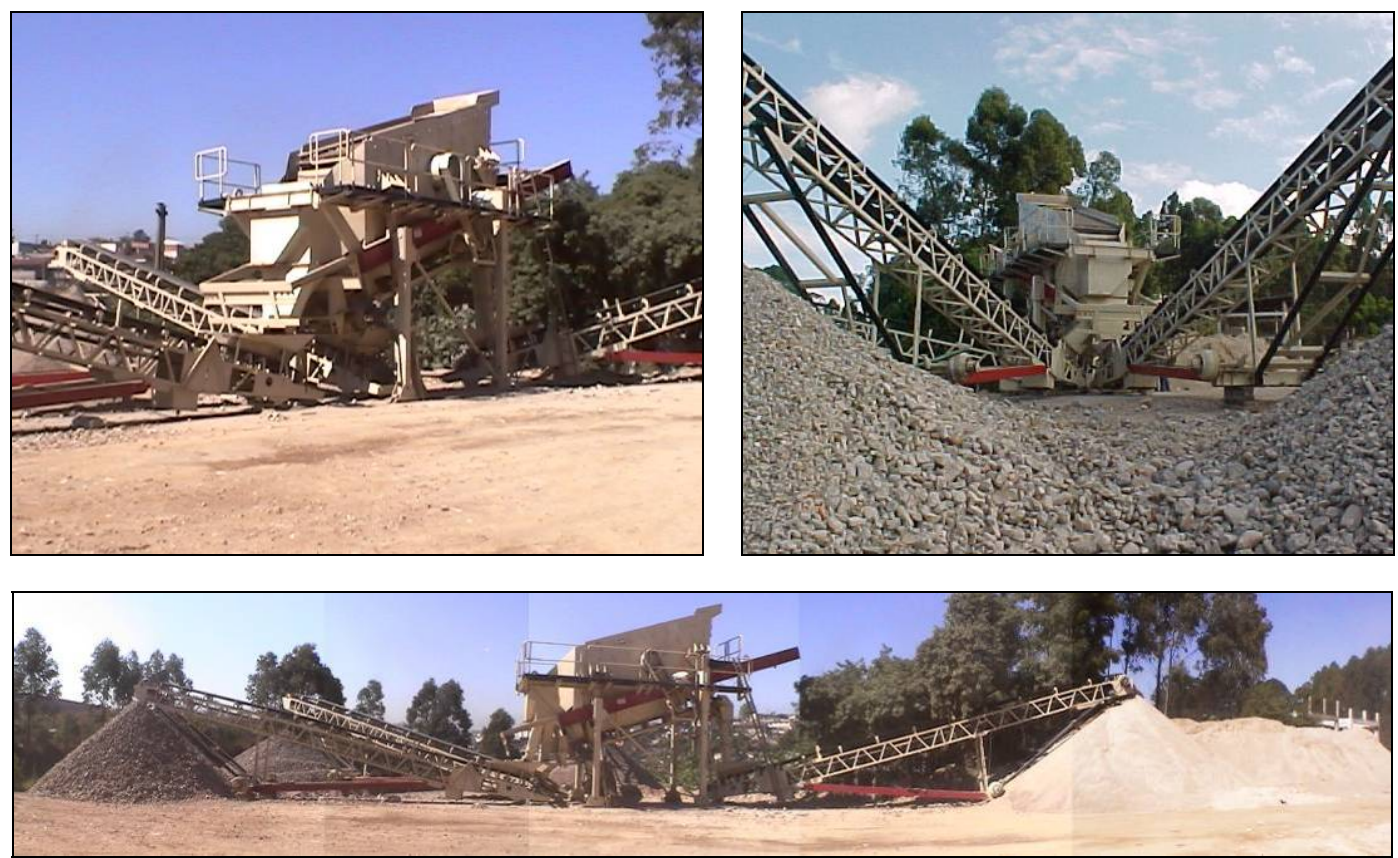

Figura 2.40 - Etapa de peneiramento na usina de Itaquera 
O fluxograma da usina de Itaquera é apresentado na Figura 2.41.

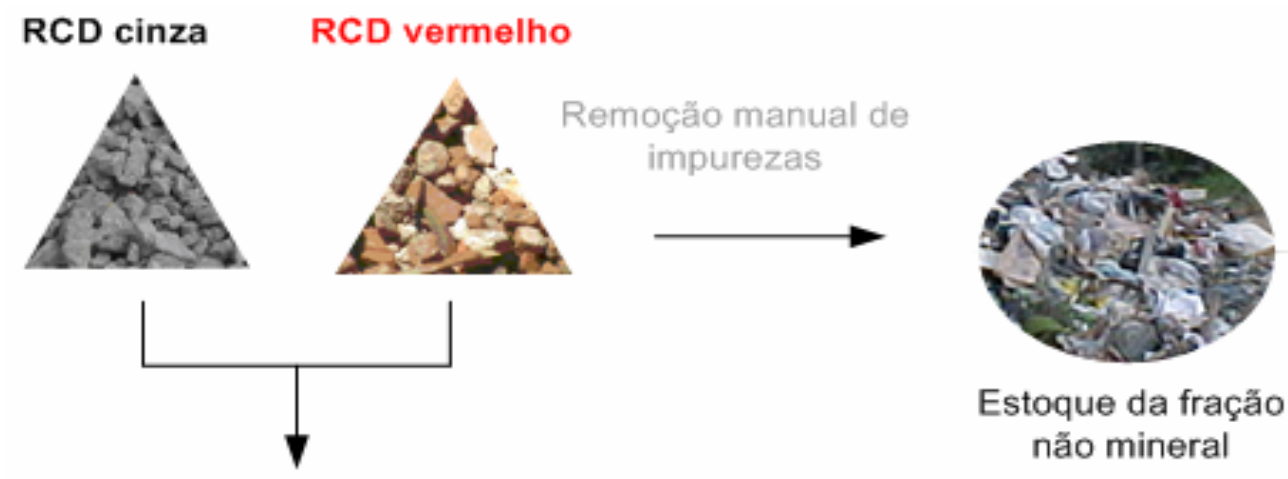

\section{Alimentação}

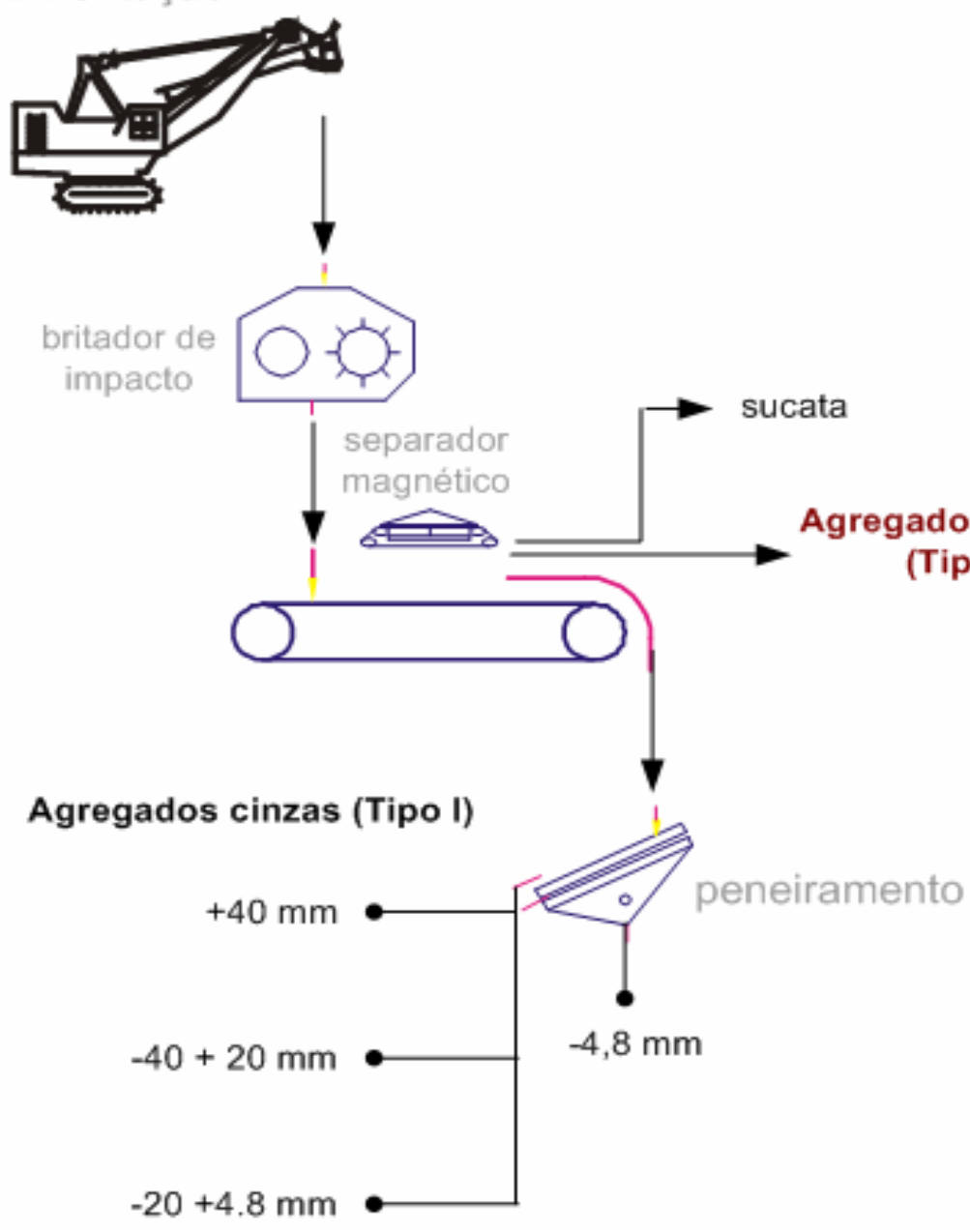

Figura 2.41 - Fluxograma da usina de reciclagem da fração mineral do RCD de Itaquera 


\subsubsection{Usina de Vinhedo, SP}

A usina localiza-se em uma área próxima ao centro urbano da cidade de Vinhedo, interior da capital paulista. Trata-se de uma usina de pequeno porte (Figura 2.42) instalada em uma área de $4.750 \mathrm{~m}^{2}$, com capacidade de processar $52 \mathrm{t} /$ dia de RCD, em que $75 \%$ do material recebido é classificado como vermelho (principalmente blocos, tijolos e argamassas - Figura 2.43a) e 25\% como cinza (elementos construtivos como contrapiso, viga, bloco, cerâmica vidrada - Figura 2.43b). Em 2002 trabalhavam na usina quatro funcionários, sendo um na etapa de seleção manual, um motorista da retroescavadeira, um no britador e um gerente; nesta época eram processadas diariamente cerca de 40 t (77\% da capacidade máxima).

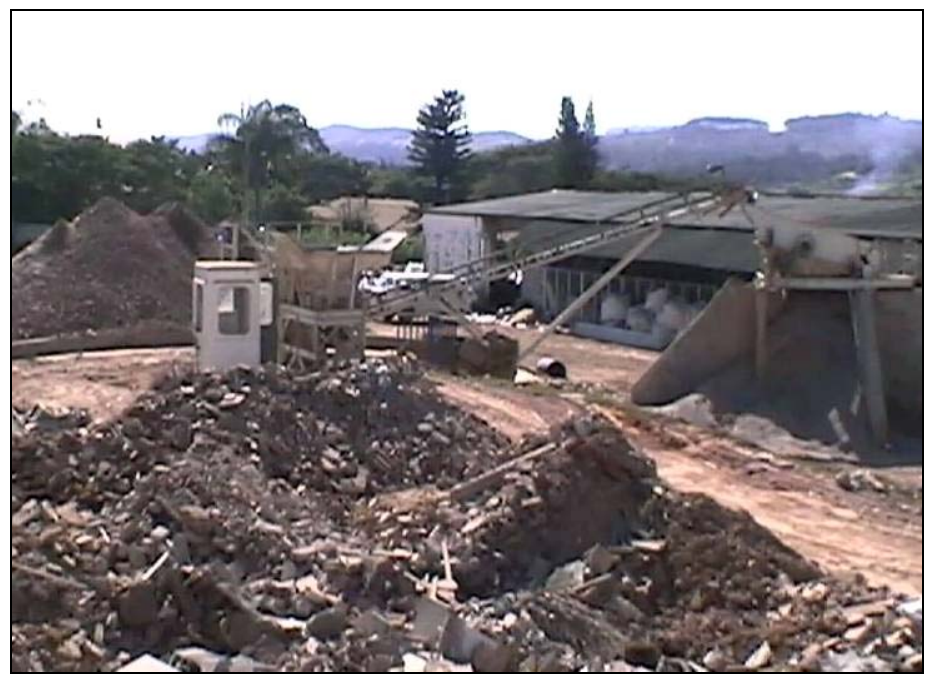

Figura 2.42 - Visão geral da usina de Vinhedo

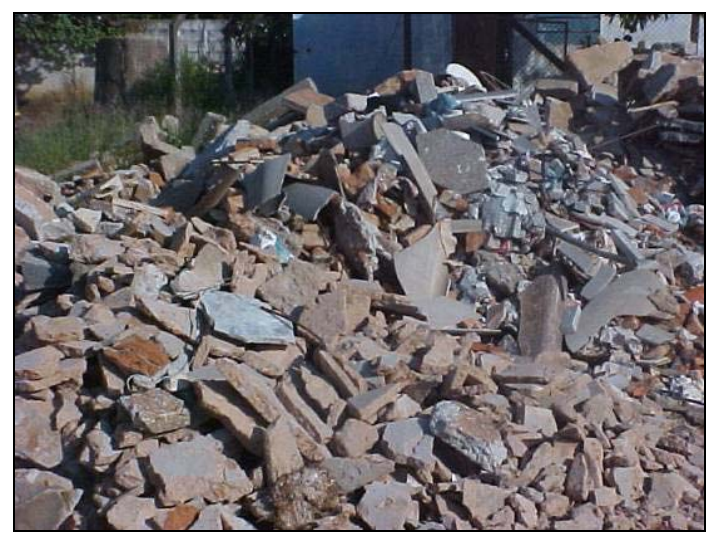

(a) - pilha de RCD cinza

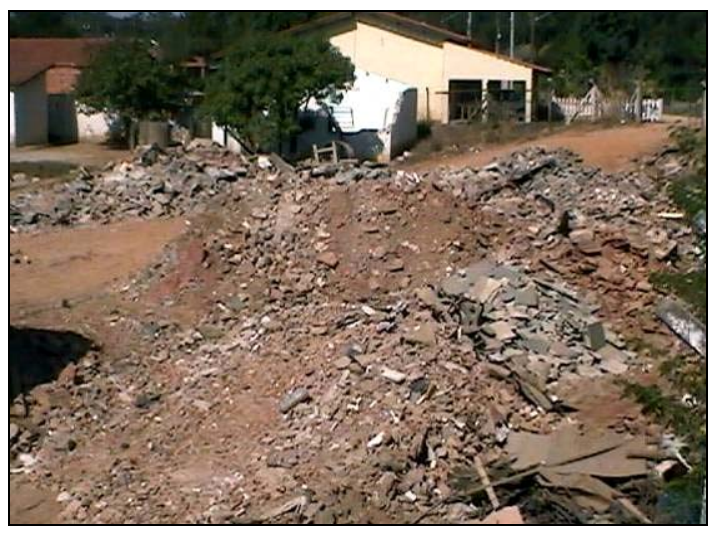

(b) - pilha de RCD vermelho

Figura 2.43 - Visão geral dos RCD processados na usina de Vinhedo 
As operações unitárias empregadas são:

- Seleção manual.

- Cominuição em britador de mandíbulas (Figura 2.44) de capacidade $8 \mathrm{t} / \mathrm{h}$, com controle do tamanho dos fragmentos na alimentação a dimensão inferior de $30 \mathrm{~cm}$.
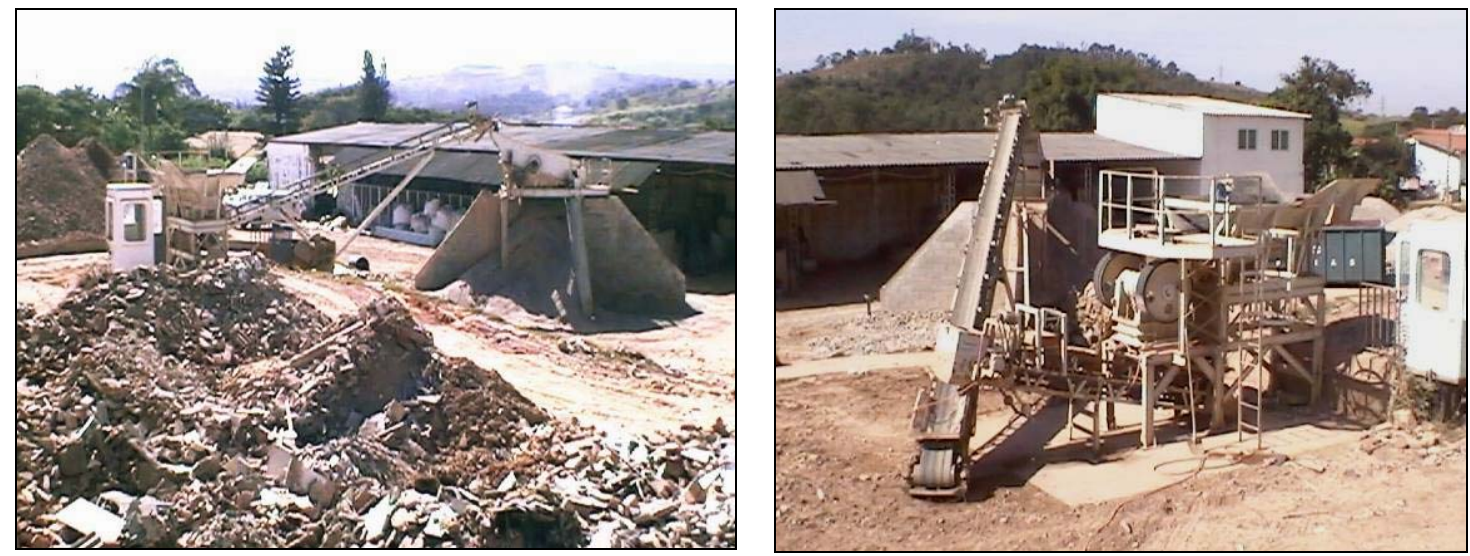

Figura 2.44 - Britador de mandíbulas da usina de vinhedo

- Classificação granulométrica por peneiramento a seco em peneira inclinada de 3 decks, com aberturas de 12,7, 9,5 e 4,8 mm (Figura 2.45).

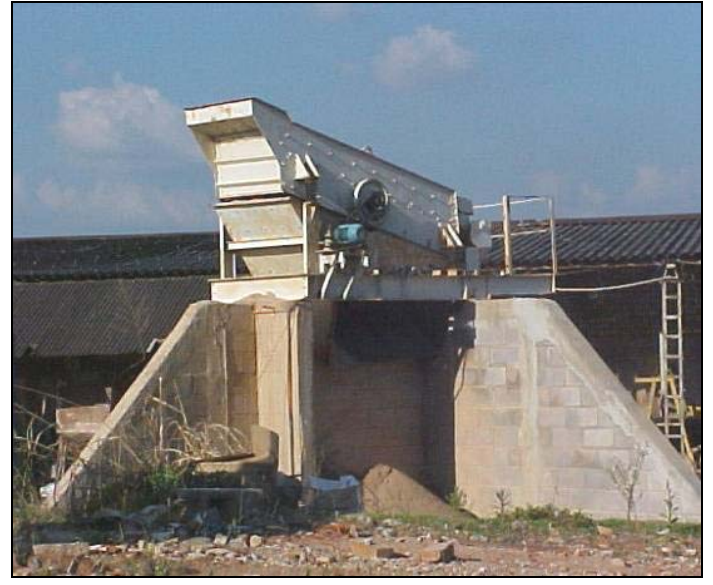

(a)

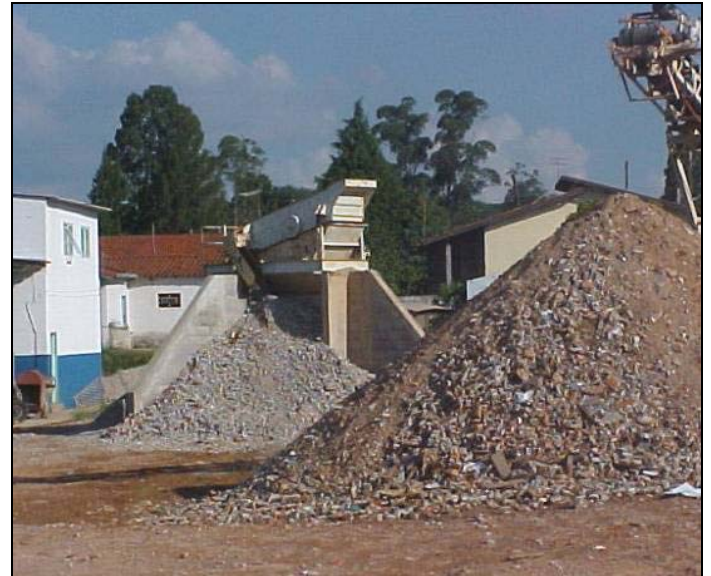

(b)

Figura 2.45 - (a) peneira inclinada (b) produto britado e classificado 
A usina de Vinhedo, cujo fluxograma é apresentado na Figura 2.46, retrata com lealdade grande parte das usinas nacionais.

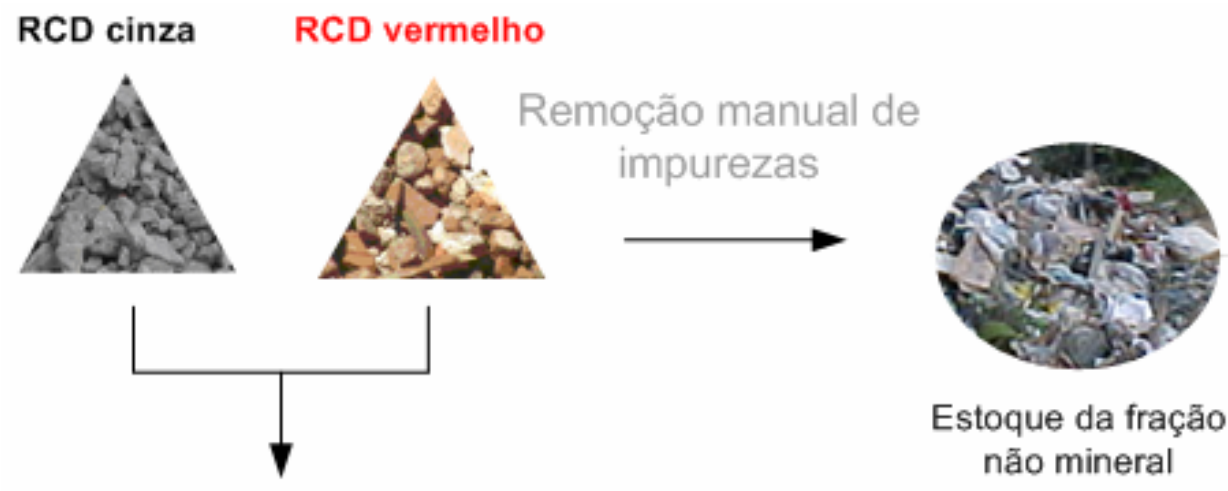

Alimentação

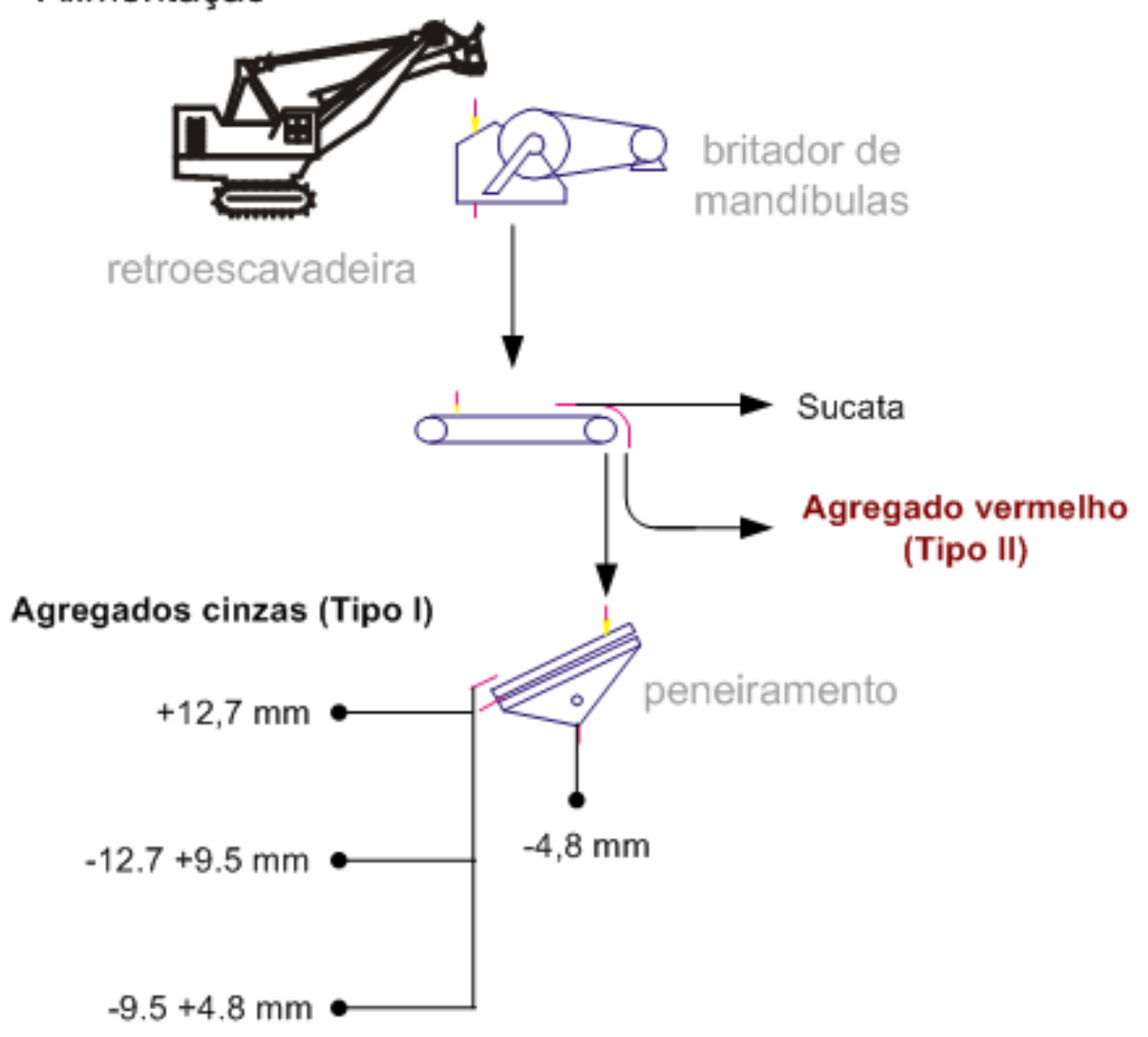

Figura 2.46 - Fluxograma da usina de reciclagem da fração mineral do RCD de Vinhedo 


\section{PROCEDIMENTO EXPERIMENTAL}

\subsection{ATIVIDADES REALIZADAS}

O procedimento experimental adotado para o estudo de caracterização tecnológica compreendeu as atividades apresentadas esquematicamente na Figura 3.1 e descritas a seguir:

- Amostragem primária e secundária dos RCD britados das usinas de Itaquera e Vinhedo, seguida da retirada de alíquotas representativas para a realização dos estudos.

- Amostragem terciária em laboratório com a retirada de alíquotas para os ensaios de caracterização; os produtos amostrados foram denominados "Tal Qual $^{12}$ - TQ".

- Análise granulométrica do TQ por peneiramento a seco ou úmido, a depender da amostra, nas peneiras com aberturas nominais de: 50,8 mm (2"); $38,1 \mathrm{~mm}$ (1 1/2"); 25,4 mm (1"); 19,1 mm (3/4") 12,7 mm (1/4"); 9,52 mm (3/8"); 4,76 mm (4 malhas); 2,38 mm (8 malhas); 1,19 mm (14 malhas); 0,59 mm (28 malhas); 0,297 mm (48 malhas); 0,149 mm (100 malhas).

- Britagem das frações de granulação superiores a $25,4 \mathrm{~mm}$ em circuito fechado com peneira, até a obtenção de todo o material passante nessa peneira. O produto da britagem secundária foi denominado "produto britado PB".

- Peneiramento do PB nas mesmas peneiras já mencionadas (abaixo de 25,4 $\mathrm{mm})$.

- Composição das frações granulométricas do PB com as frações inferiores a 25,4 mm do TQ ("finos da britagem primária - FBP") para as atividades de separações minerais.

\footnotetext{
${ }^{12}$ Foi denominado TQ o material amostrado na usina, após britagem primária.
} 
- Separações minerais seqüenciais em líquidos densos, das frações acima de $0,3 \mathrm{~mm}$, nas densidades 1,7 e $1,9 \mathrm{~g} / \mathrm{cm}^{3}$ (empregando-se solução salina de cloreto de zinco) e nas densidades 2,2 e $2,5 \mathrm{~g} / \mathrm{cm}^{3}$ (através de bromofórmio diluído com álcool etílico); obtendo-se os seguintes produtos:

- flutuado em $1,7 \mathrm{~g} / \mathrm{cm}^{3}$

- afundado em 1,7 e flutuado em $1,9 \mathrm{~g} / \mathrm{cm}^{3}$

- afundado em 1,9 e flutuado em $2,2 \mathrm{~g} / \mathrm{cm}^{3}$

- afundado em 2,2 e flutuado em $2,5 \mathrm{~g} / \mathrm{cm}^{3}$

- afundado em $2,5 \mathrm{~g} / \mathrm{cm}^{3}$

- Análises químicas por fluorescência de raios X, por faixa granulométrica, do TQ, PB e produtos de separações minerais, com determinações de $\mathrm{SiO}_{2}$, $\mathrm{Al}_{2} \mathrm{O}_{3}, \mathrm{Fe}_{2} \mathrm{O}_{3}, \mathrm{CaO}, \mathrm{MgO}, \mathrm{Na}_{2} \mathrm{O}, \mathrm{K}_{2} \mathrm{O}, \mathrm{MnO}, \mathrm{TiO}_{2}, \mathrm{P}_{2} \mathrm{O}_{5}$ e $\mathrm{SO}_{3}$, além de perda ao fogo a $1050^{\circ} \mathrm{C}$. Determinações de resíduo insolúvel foram realizadas por via úmida nos produtos de separações minerais.

- Análises mineralógicas por difratometria de raios X das frações graúda, miúda, finos $<0,15 \mathrm{~mm}$, bem como dos produtos de separações minerais.

- Caracterização microestrutural de produtos de separações minerais através da combinação de técnicas de microscopia estereoscópica e óptica.

- Caracterização de propriedades físicas: massa específica real e absorção de água. 


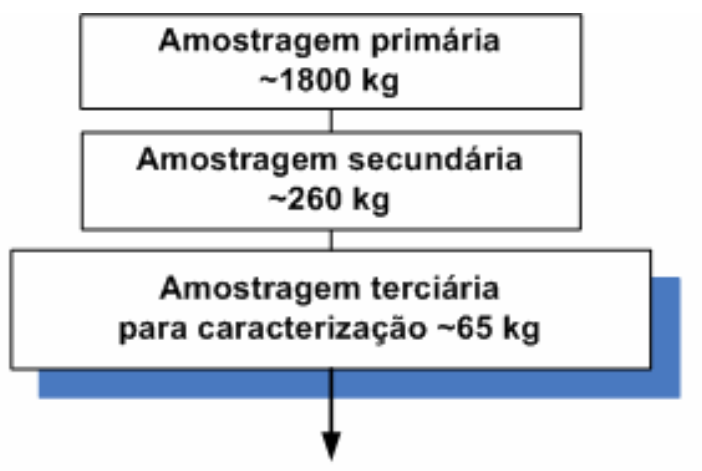

Peneiramento em 50,$8 ; 38,1 ; 25,4 ; 19,1 ; 12,7 ; 9,52$;

4,$76 ; 2,38 ; 1,19 ; 0,59 ; 0,297 ; 0,149 \mathrm{~mm}$

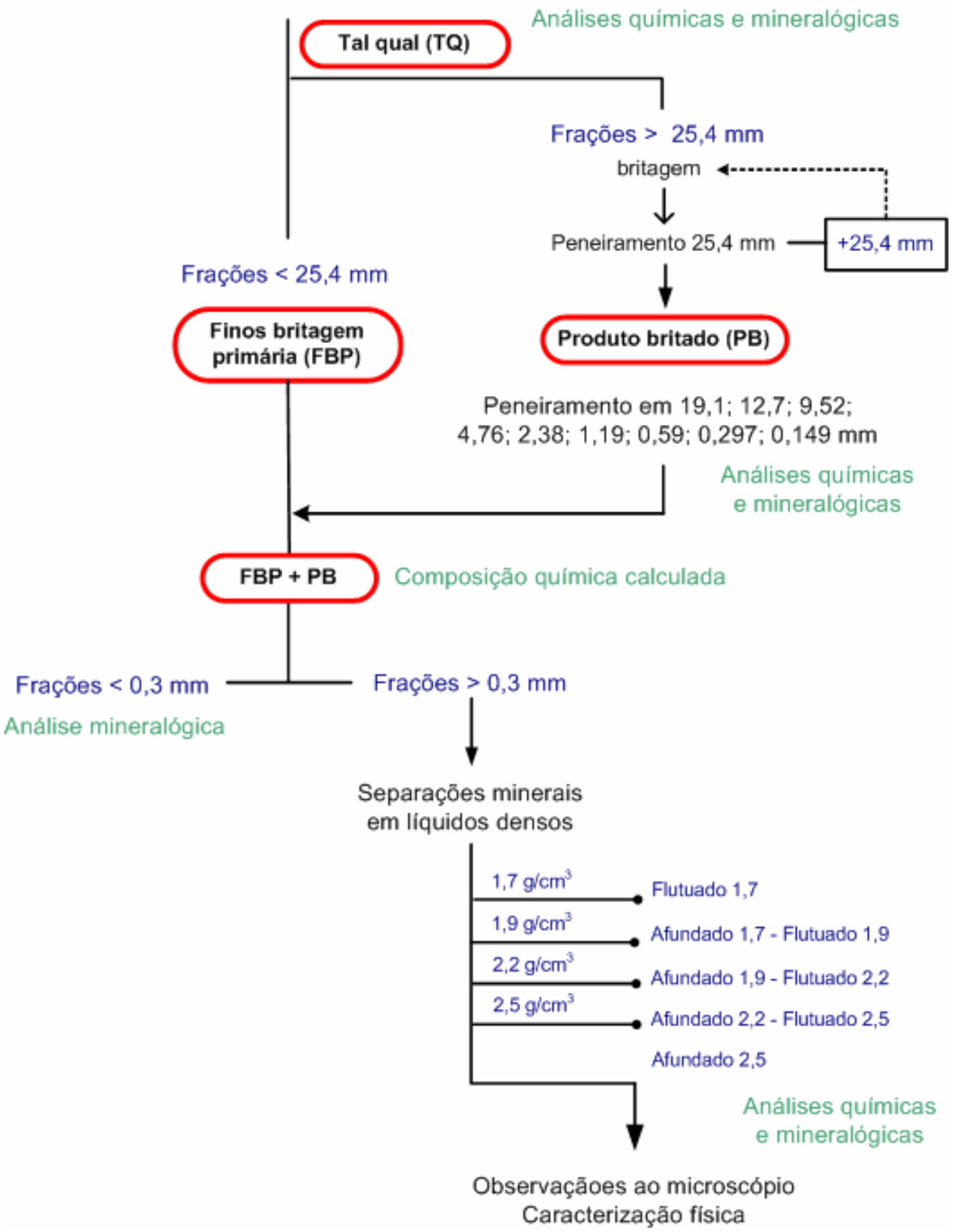

Figura 3.1 - Esquema de procedimento experimental 


\subsection{AMOSTRAGEM}

As duas usinas de reciclagem amostradas foram assim escolhidas face à proximidade do local de realização da pesquisa, às diferenças de arranjos e porte das usinas, bem como natureza de sua matéria prima (em virtude das diferenças de métodos construtivos) e à produção de diferentes tipos de agregados.

Ambas processam resíduos cinza e vermelho, entretanto em virtude da escassez do material cinza na usina de Vinhedo, a amostragem nessa instalação foi restrita exclusivamente ao produto vermelho. As amostras coletadas serão referenciadas segundo as siglas:

- IT-C: Itaquera cinza

- IT-V: Itaquera vermelho

- VI-V: Vinhedo vermelho

A coleta de amostras foi realizada na saída do transportador de correia, após a britagem e separação magnética (no caso de Itaquera) e antes da etapa de peneiramento. A coleta das amostras foi realizada por funcionários das usinas após a devida orientação dos mesmos, segundo procedimento descrito a seguir (Figura 3.2).

1 - distribuição do material em pilha alongada

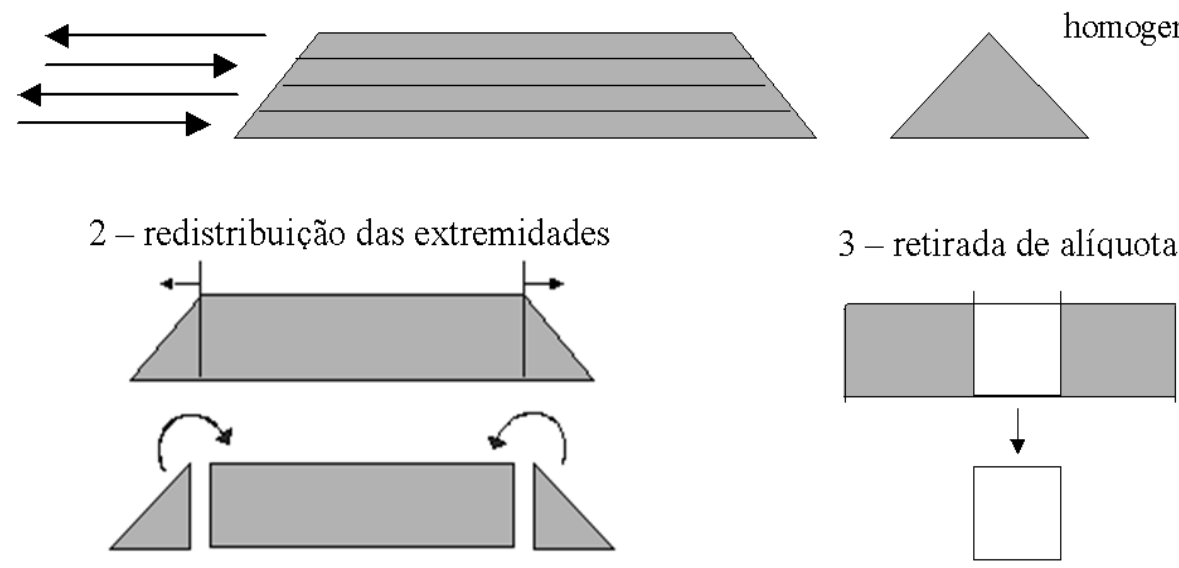

Figura 3.2 - Procedimento para homogeneização em pilha alongada 
A cada dia de produção foram coletadas 4 latas de $18 \mathrm{~L}$ em intervalos de tempo regulares durante o período diário de operação da usina (cerca de $4 \mathrm{~h}$ ), resultando na coleta de 1 lata/h. Este plano de amostragem é conhecido como sistemático com incrementos coletados em intervalos regulares (LUZ et al., 1998).

No final de cada dia de produção as latas coletadas eram distribuídas de maneira uniforme e ininterrupta ao longo de uma pilha alongada de seção triangular, em camadas sucessivas e em direções alternadas. Após 20 dias de produção foram coletadas cerca de $1.800 \mathrm{~kg}$ de cada tipo de material ${ }^{13}$; quando terminada a execução de cada pilha, as extremidades eram retomadas e redistribuídas segundo o mesmo procedimento. A produção ${ }^{14}$ da usina de Itaquera no período de amostragem foi estimada em $8.000 \mathrm{t}$ e a de Vinhedo em $1.040 \mathrm{t}$, dessa forma as amostras representam, respectivamente, 0,02 e $0,18 \%$ em massa do total produzido no período.

A Figura 3.3 ilustra a pilha alongada confeccionada na usina de Itaquera para o produto vermelho.

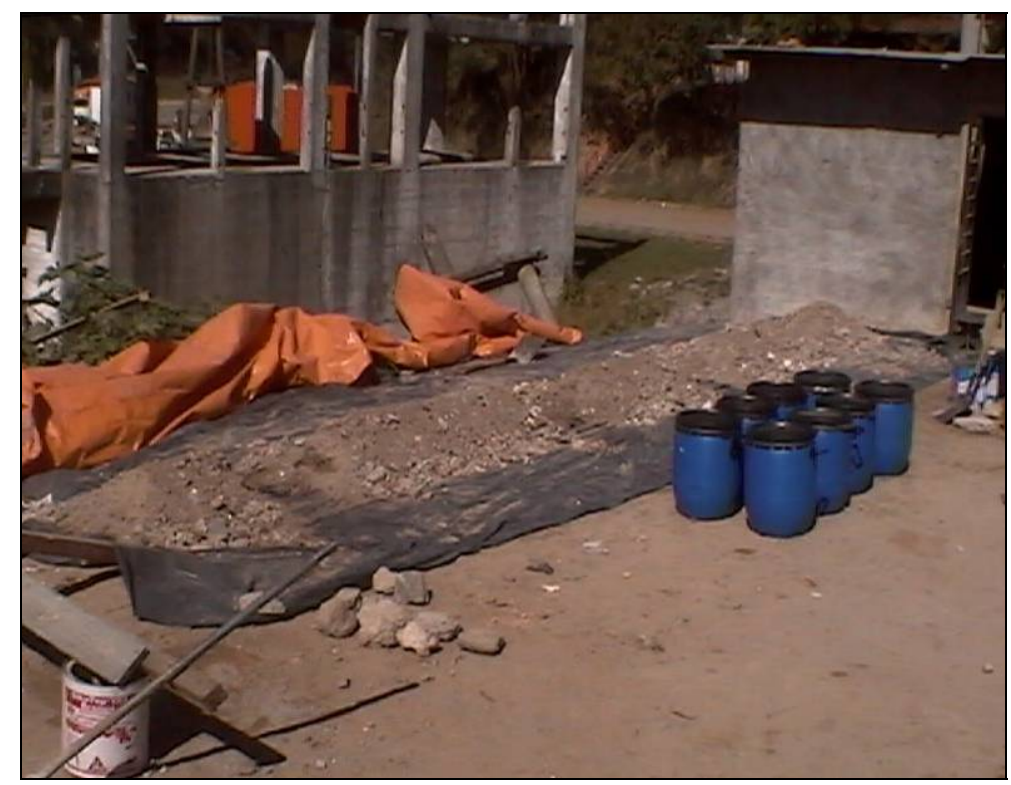

Figura 3.3 - Pilha de homogeneização na usina de Itaquera (produto IT-V)

13 Amostragem de 4 latas de $18 \mathrm{dm}^{3}$ (L) ao dia, por 20 dias, para cada uma das três amostras, com massa unitária de $1,3 \mathrm{~kg} / \mathrm{dm}^{3}$ (ZORDAN, 1997). A quantidade de material amostrada foi determinada segundo o critério de Rychards, considerando o diâmetro da maior partícula de $50 \mathrm{~mm}$ e o material amostrado como uniforme.

${ }^{14}$ A produção na usina de Itaquera era da ordem de 400 t/dia e a de Vinhedo de 52 t/dia 
Em seguida, quatro alíquotas de $65 \mathrm{~kg}$ cada (cerca de 14\% do total, em massa) foram retiradas da pilha e armazenadas em laboratório.

As quatro alíquotas coletadas foram recompostas e novamente homogeneizadas em pilha alongada nos laboratórios da EPUSP (Figura 3.4). A pilha resultante foi dividida em quatro partes de aproximadamente $65 \mathrm{~kg}$ cada, que foram posteriormente armazenadas em recipientes individuais para os estudos posteriores.

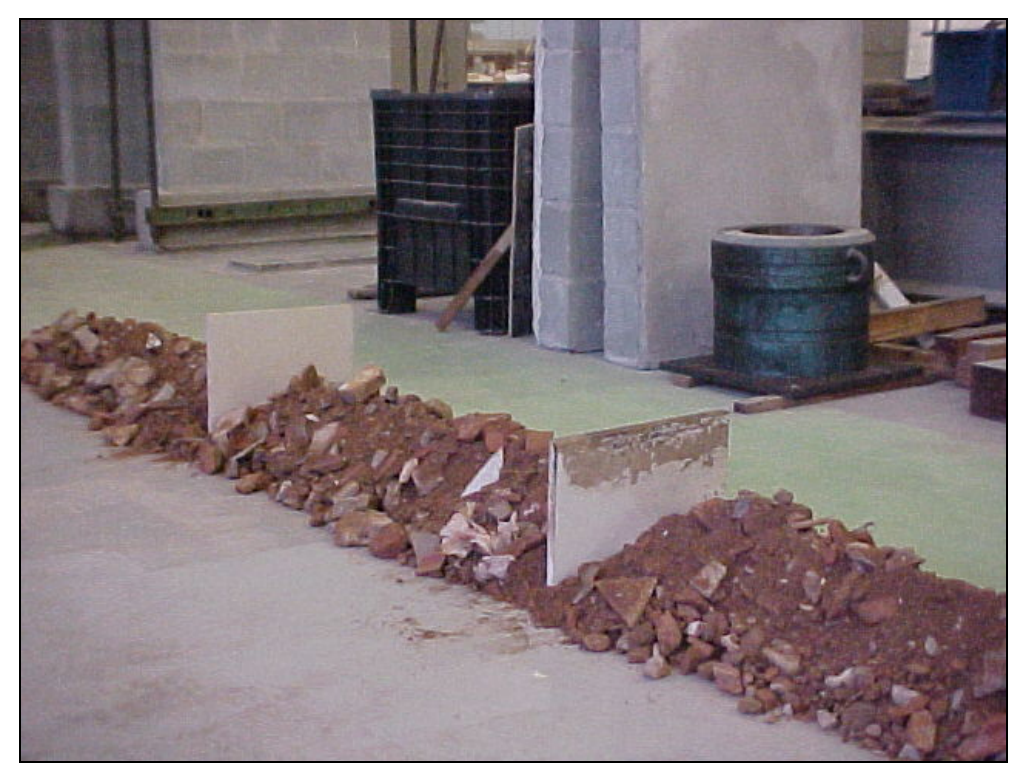

Figura 3.4 - Re-homogeneização e amostragem do produto VI-V

\subsection{ANÁLISE GRANULOMÉTRICA E BRITAGEM SECUNDÁRIA}

A análise granulométrica foi realizada por peneiramento a seco para os produtos de Itaquera, e a úmido para o RCD de Vinhedo com o objetivo aumentar a eficiência para as frações finas.

O peneiramento foi realizado em um peneirador mecânico (úmido ou seco a depender da amostra), marca Produtest (Figura 3.5), num conjunto de três peneiras quadradas em cada etapa; as peneiras apresentam dimensões $50 \times 50 \times 10 \mathrm{~cm}$, com tela em aço inox nas seguintes aberturas nominais: 50,8;39,1;25,4;19,1;12,7; 9,5; 4,$8 ; 2,4 ; 1,2 ; 0,59 \mathrm{~mm}$. As frações subseqüentes (passante em $0,59 \mathrm{~mm}$ ) foram 
peneiradas em peneirador mecânico com peneiras circulares de $20 \mathrm{~cm}$ de diâmetro nas malhas de abertura 0,297 e 0,149 mm (Figura 3.6).

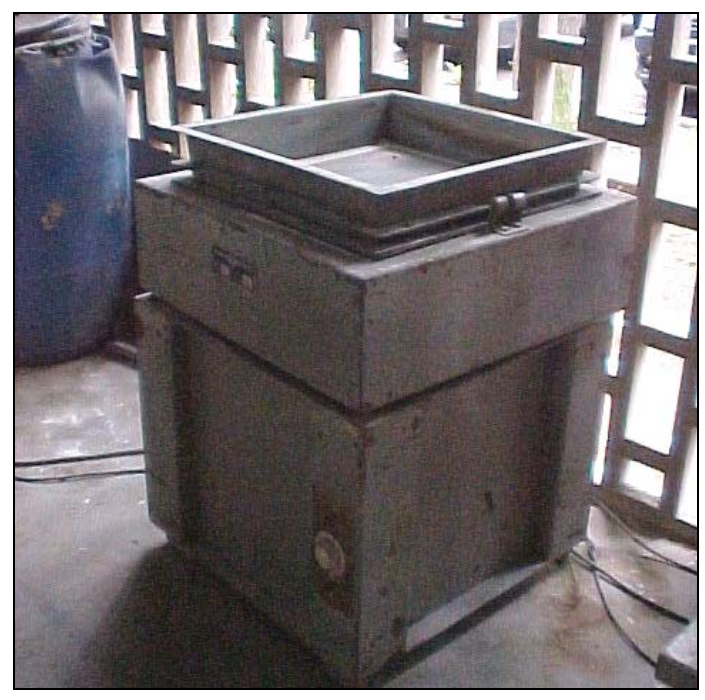

Figura 3.5 - Peneirador mecânico para peneiras quadradas de 50 x $50 \mathrm{~cm}$

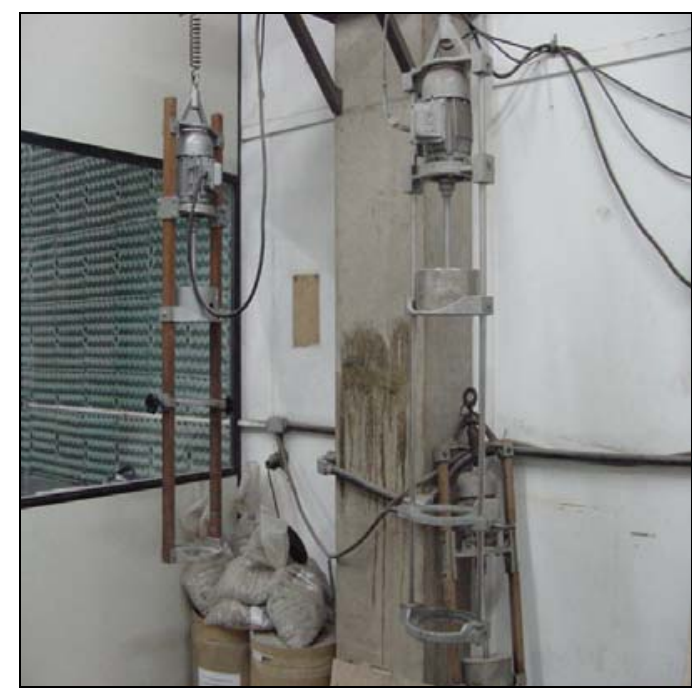

Figura 3.6 - Peneirador mecânico para peneiras circulares de $20 \mathrm{~cm}$ de diâmetro

No peneiramento a úmido as frações foram lavadas intensivamente, com recuperação e recirculação da água (Figura 3.18).

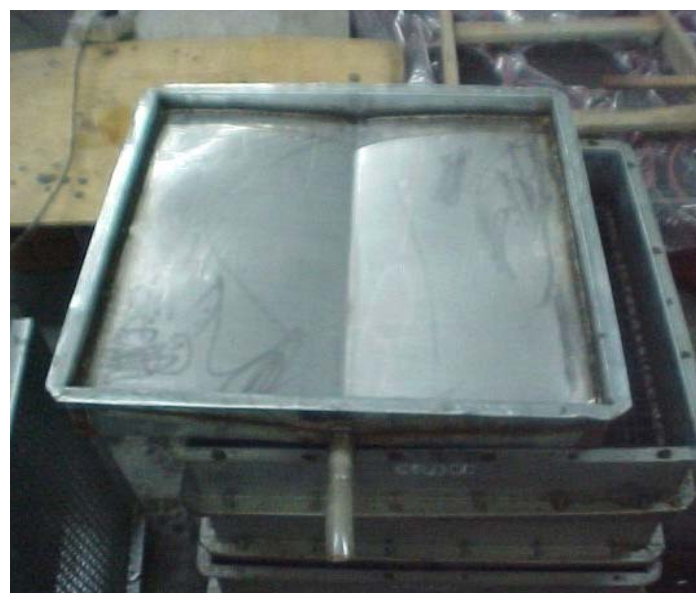

(a)

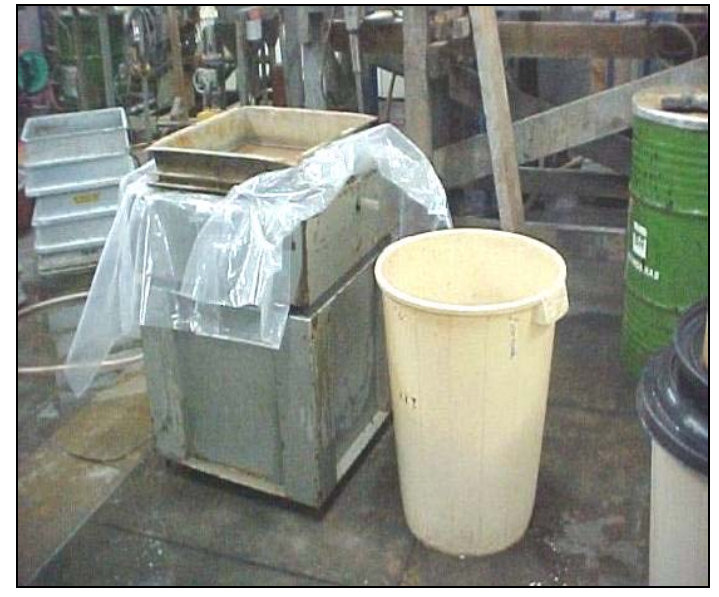

(b)

Figura 3.7 - Peneiramento a úmido: (a) fundo adaptado e (b) recuperação da água no balde para recirculação

As frações maiores que $25,4 \mathrm{~mm}(50,8 ; 38,1$ e $25,4 \mathrm{~mm})$ foram britadas em britador de mandíbulas (marca Furlan, modelo BM 2010 - Figura 3.8) em circuito fechado 
com peneira até obtenção de todo material passante em $25,4 \mathrm{~mm}$. O produto obtido foi denominado "produto britado - $P B$ ", este foi novamente peneirado de acordo com o procedimento anteriormente descrito. As frações do material inicialmente amostrado de granulometria naturalmente inferior a $25,4 \mathrm{~mm}$ foram denominadas “finos da britagem primária - FBP”.
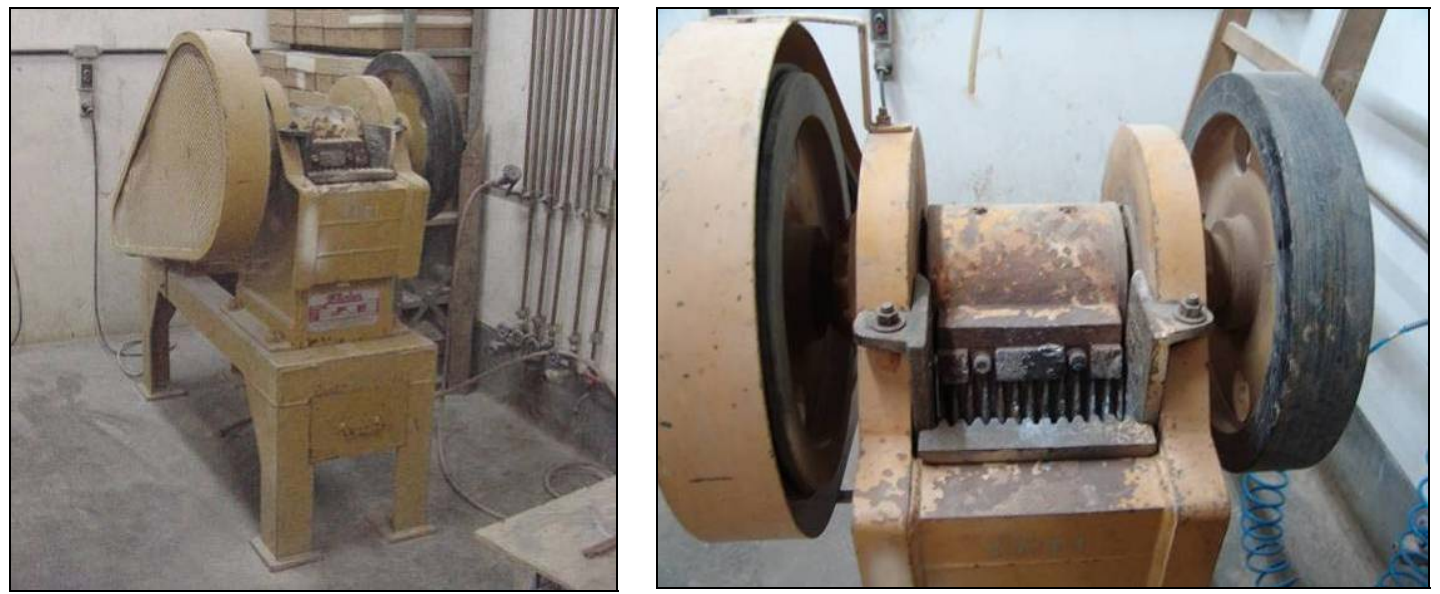

Figura 3.8 - Britador de mandíbulas, escala de laboratório

\subsection{CARACTERIZAÇÃO QUÍMICA}

Todos os produtos gerados pela análise granulométrica foram objetos de análises químicas. As amostras foram preparadas segundo procedimento descrito a seguir.

- Cominuição abaixo de $1 \mathrm{~mm}$ em moinho de rolos, marca Furlan, modelo S90L4 (Figura 3.9).
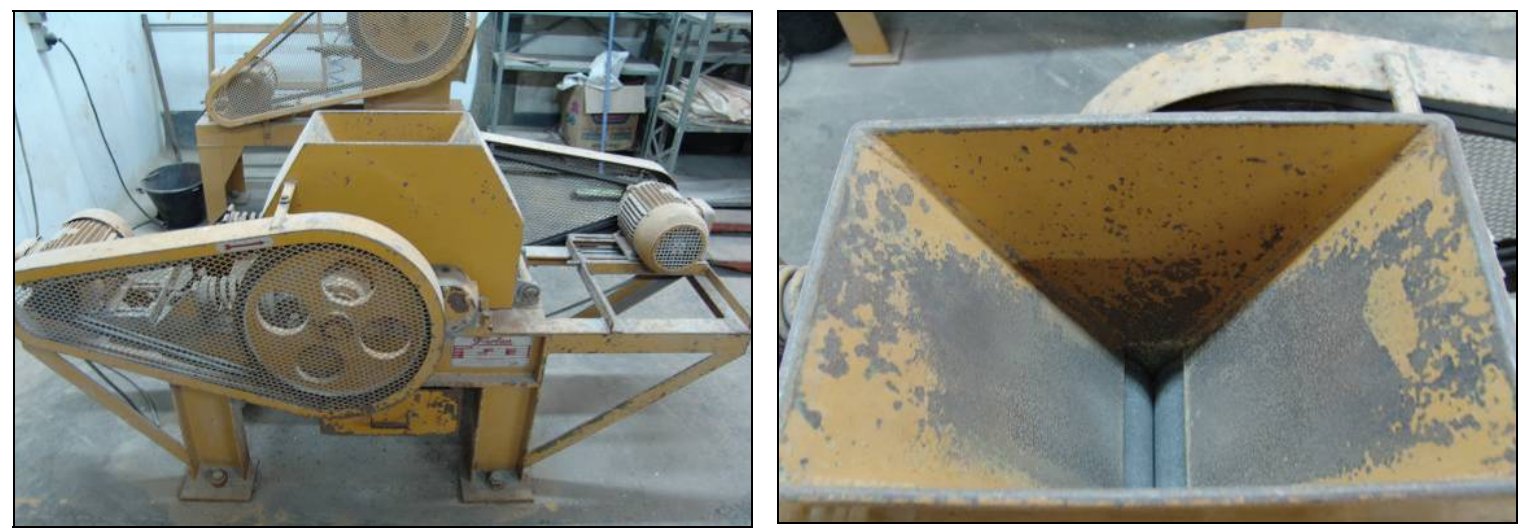

Figura 3.9 - Moinho de rolos 
- Pulverização em moinhos de discos oscilantes, Herzog HSM 250P (Figura 3.10) para redução das partículas abaixo de $20 \mu \mathrm{m}$
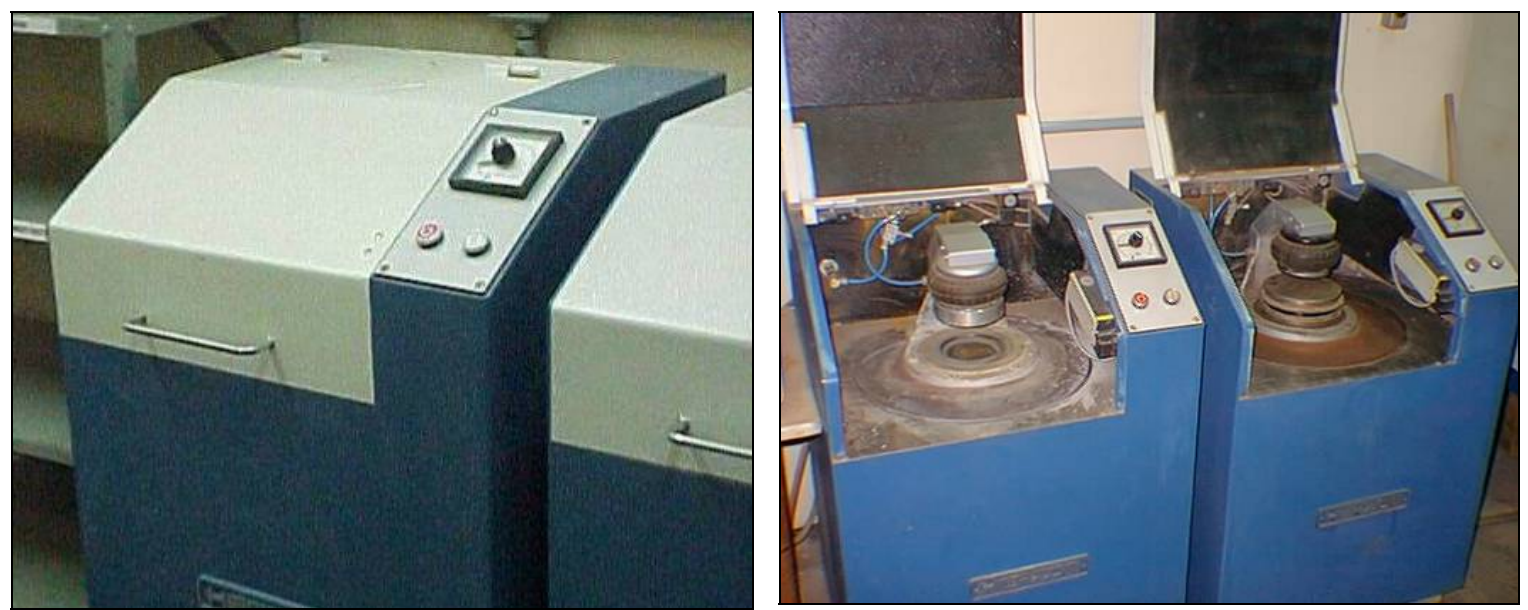

Figura 3.10 - Moinho de rolos

- Fusão das amostras para confecção de pastilhas fundidas (Figuras $3.11 \mathrm{e}$ $3.12)$.

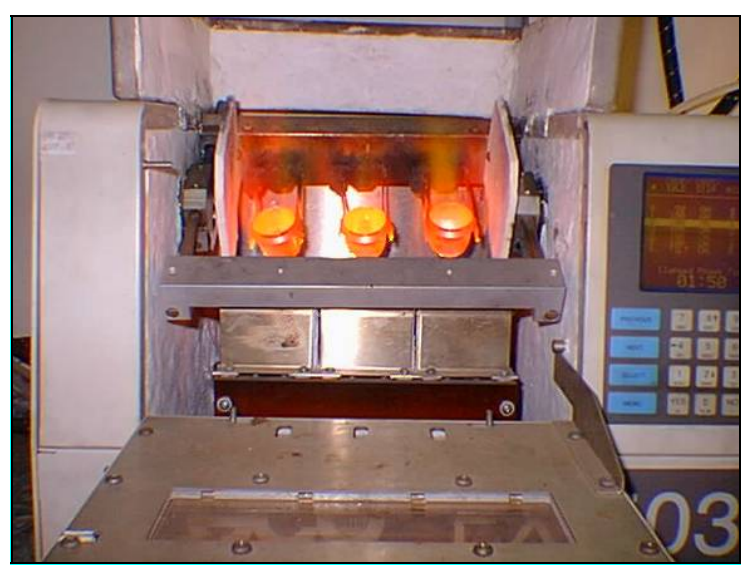

Figura 3.11 - Máquina de fusão

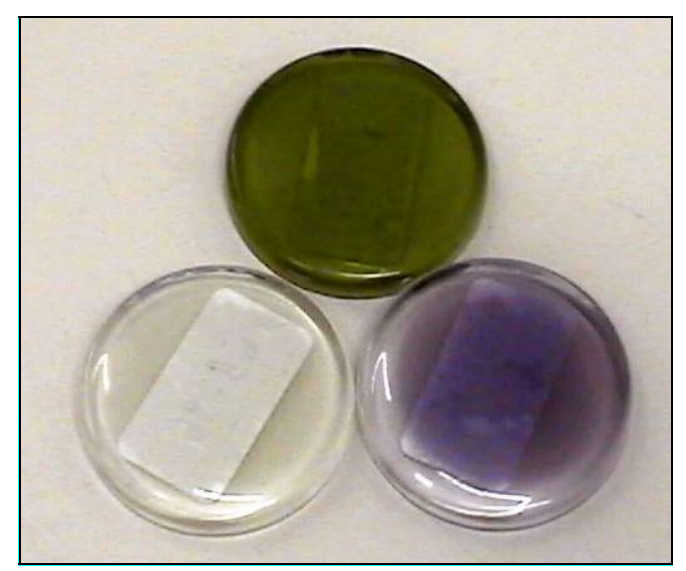

Figura 3.12 - Pastilha fundida

A técnica utilizada para as análises químicas das amostras foi espectrometria de fluorescência de raios X (FRX) através de espectrômetro Magix Pro, marca PANalytical. As análises foram realizadas no Laboratório de Caracterização Tecnológica do Departamento de Engenharia de Minas e de Petróleo da Universidade de São Paulo a partir de pérolas fundidas (1g de amostra para $7 \mathrm{~g}$ de 
fundente) com determinações sistemáticas de $\mathrm{SiO}_{2}, \mathrm{Fe}_{2} \mathrm{O}_{3}, \mathrm{Al}_{2} \mathrm{O}_{3}, \mathrm{CaO}, \mathrm{MgO}, \mathrm{Na}_{2} \mathrm{O}$, $\mathrm{K}_{2} \mathrm{O}, \mathrm{MnO}, \mathrm{TiO}_{2}, \mathrm{P}_{2} \mathrm{O}_{5}$ e $\mathrm{SO}_{3}$, além de perda ao fogo a $1050^{\circ} \mathrm{C}$.

O resíduo insolúvel (RI) foi estimado por via úmida através da reação de uma alíquota de material seco e pulverizado, de cerca de 20 g, com $100 \mathrm{~mL}$ de solução de ácido clorídrico $(\mathrm{HCl})$ a 20\%. Parte da amostra, os aglomerantes solúveis, reage com o $\mathrm{HCl}$; a porção restante é denominada resíduo insolúvel, sendo este composto essencialmente por argilominerais, quartzo e feldspatos (QUARCIONI, 1998). O RI é calculado pelo quociente entre a massa final e a inicial secas a $100^{\circ} \mathrm{C}(\mathrm{em}$ porcentagem). O teor de aglomerantes, por sua vez, é a fração da amostra que reagiu com o $\mathrm{HCl}$, sendo determinado a partir da Equação 3.1.

$$
\text { A (\%) = 1 - RI (\%) } \quad \text { (Equação 3.1) }
$$

\subsection{SEPARAÇÃO EM LÍQUIDOS DENSOS - CURVA DE SEPARABILIDADE}

O objetivo deste ensaio foi avaliar a distribuição em massa e estimar o teor de contaminantes nos produtos de cada intervalo de densidade, bem como as composições química e mineralógica dos produtos.

Para cada intervalo granulométrico acima de $0,30 \mathrm{~mm}$ foram retiradas alíquotas dos produtos FBP e PB através de amostrador Jones. Em seguida, frações dos dois produtos foram compostas proporcionalmente à partição em massa destas na amostra de modo a formar um único produto $(\mathrm{FBP}+\mathrm{PB})$.

Também foram reagrupadas algumas frações granulométricas, de modo a minimizar o número de produtos para realização dos ensaios em líquidos densos, resultando nas seguintes frações: $-25,4+19,1 \mathrm{~mm} ;-19,1+12,7 \mathrm{~mm} ;-12,7+9,5 \mathrm{~mm} ;-9,5+4,8 \mathrm{~mm}$; $-4,8+1,2 \mathrm{~mm}$ e $-1,2+0,3 \mathrm{~mm}$, que foram submetidas a separações em quatro densidades: 1,$7 ; 1,9 ; 2,2$ e $2,5 \mathrm{~g} / \mathrm{cm}^{3}$.

O ensaio de separações em líquido denso para o estabelecimento de uma curva de separabilidade por densidade emprega líquidos em ordem crescente de densidade, conforme esquema apresentado na Figura 3.13. Os produto flutuados devem ser 
pesados e analisados, o processo de separação é repetido sucessivamente para os produtos afundados até a maior densidade considerada; a fração final de afundado obtida também deve ser pesada e analisada (BURT, 1984).

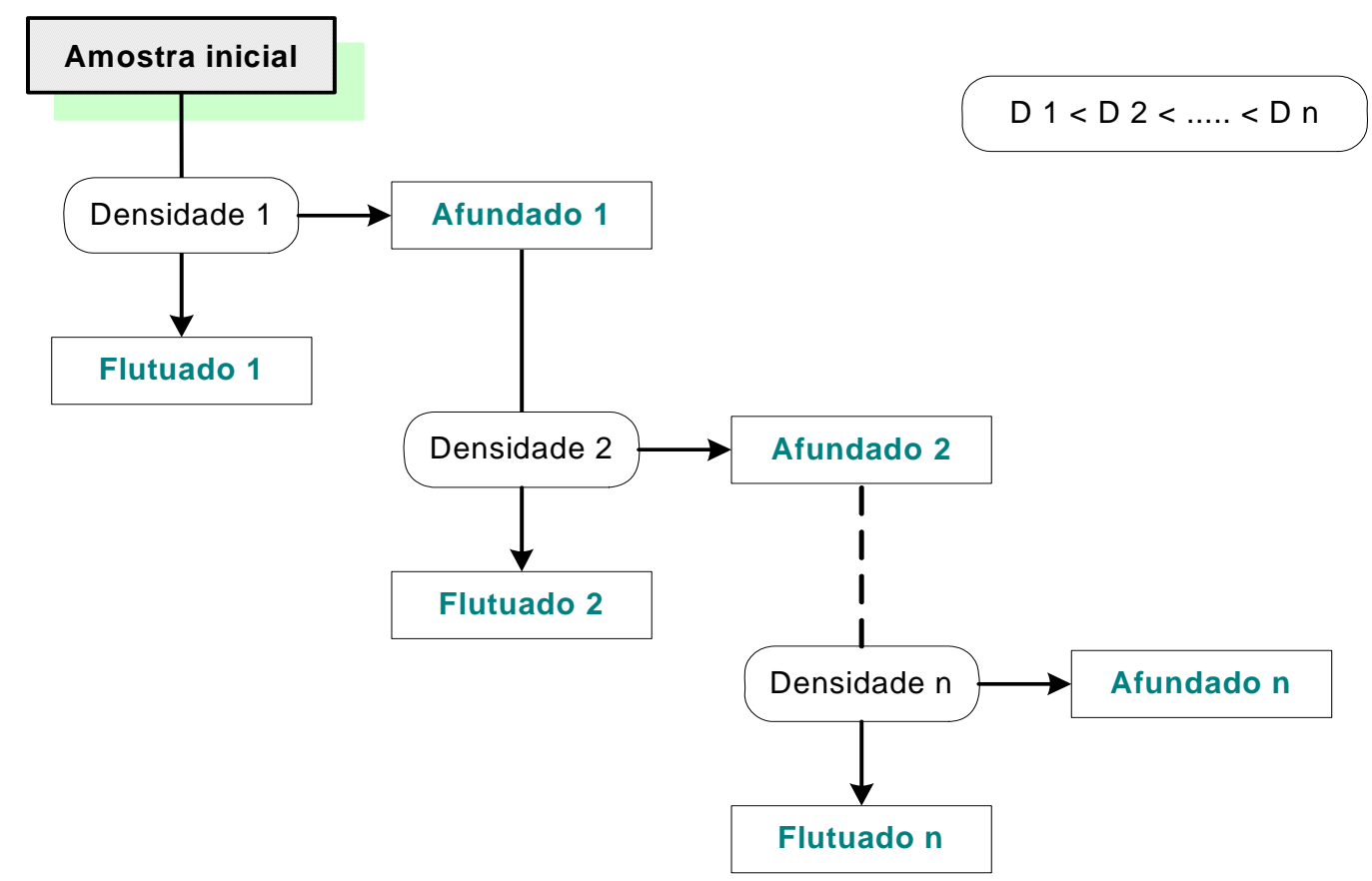

Figura 3.13 - Separação seqüencial em líquidos densos para se estabelecer uma curva de separabilidade por densidade (BURT, 1984, modificado)

As densidades de 1,7 e $1,9 \mathrm{~g} / \mathrm{cm}^{3}$ foram obtidas através de solução salina de cloreto de zinco $\left(\mathrm{ZnCl}_{2}\right)$ em água. Neste caso não há necessidade de utilização de capela com ventilação, uma vez que a solução em questão não libera vapores tóxicos. Inicialmente, a separação é realizada na densidade de $1,7 \mathrm{~g} / \mathrm{cm}^{3}$, o material flutuado em 1,7 já é produto final (Flut. 1,7); para o afundado repete-se o procedimento em solução de $1,9 \mathrm{~g} / \mathrm{cm}^{3}$, novamente o material flutuado em 1,9 é produto final (Af. 1,7 Flut 1,9). A separação foi conduzida em balde para as frações acima de 9,52 mm; em béqueres para as duas frações seguintes $(4,8$ e 1,2 mm) e em funil tipo Squib para a fração mais fina $(0,3 \mathrm{~mm})$.

A Figura 3.14 ilustra alguns dos acessórios utilizados na separação em cloreto de zinco. 

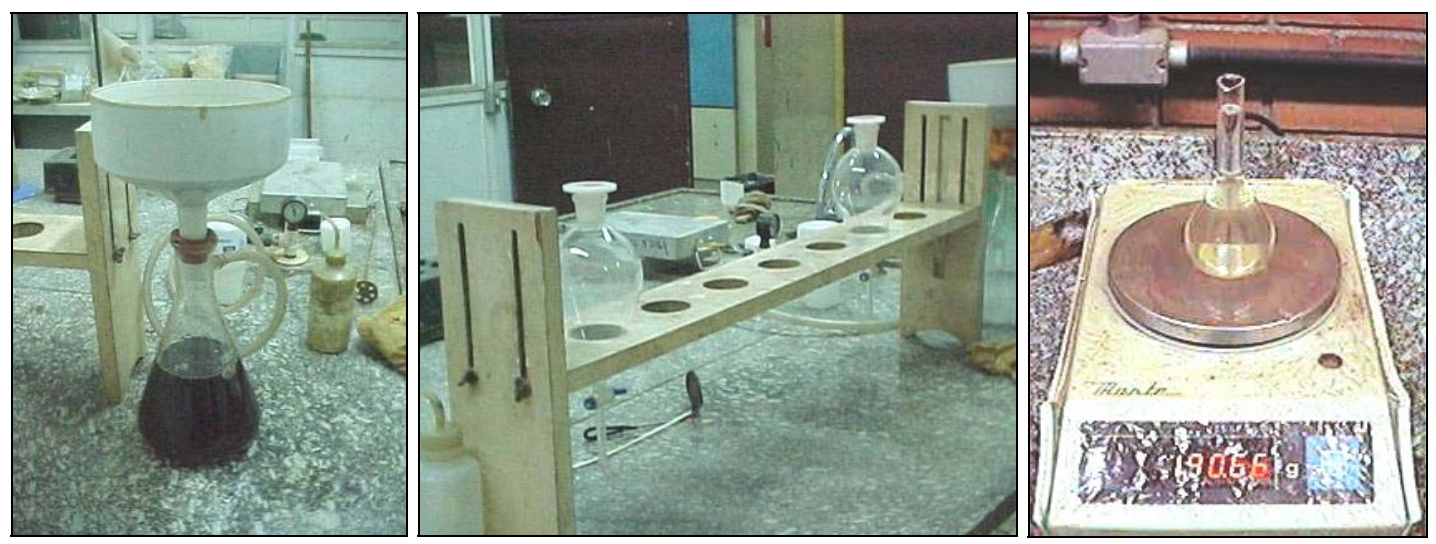

Figura 3.14 - Acessórios utilizados para separação em cloreto de zinco

(a) Kitassato, funil e filtro de papel para remoção do líquido denso da superfície dos grãos; (b) Funil para separação densitária da fração $+0,3 \mathrm{~mm}$; (c) Balança para ajuste da densidade de $\mathrm{ZnCl}_{2}$

O procedimento se repete para o produto afundado em $1,9 \mathrm{~g} / \mathrm{cm}^{3}$ nas densidades 2,2 e, na seqüência, em $2,5 \mathrm{~g} / \mathrm{cm}^{3}$, utilizando-se bromofórmio como líquido denso e álcool etílico para ajuste das densidades (solvente). Cuidados extras devem ser tomados uma vez que o líquido em questão libera vapores tóxicos e deve ser manuseado em capela com exaustão de ar, utilização de máscara para gases e luvas, evitando qualquer contato com a pele ou inalação.

Ao final do ensaio foram obtidos 5 produtos para cada fração granulométrica: $d<1,7$; $1,7<\mathrm{d}<1,9 ; 1,9<\mathrm{d}<2,2 ; 2,2<\mathrm{d}<2,5$ e d $>2,5\left(\mathrm{~d} \mathrm{em} \mathrm{g} / \mathrm{cm}^{3}\right)$.

A Figura 3.15 mostra o procedimento seguido em cada etapa de separação tendo-se, por exemplo, a separação efetuada em béquer. 
1) Imersão partículas no líquido denso

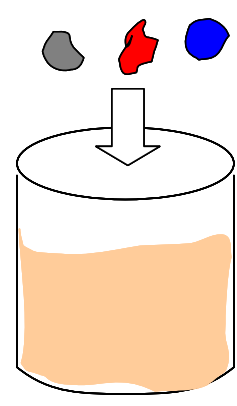

4) Retirada do flutuado por cesto

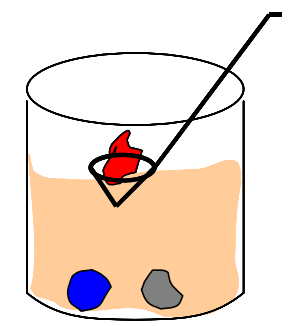

2) Agitação
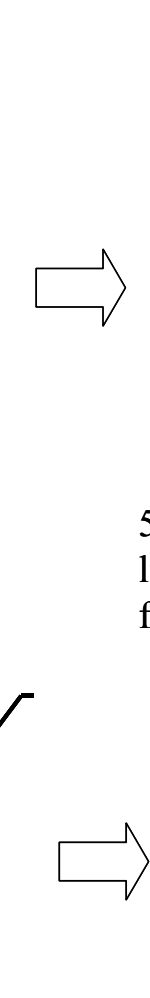

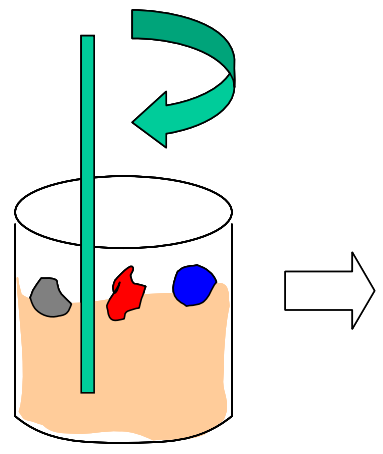

5) Recuperação do líquido denso por filtragem no flutuado
3) Definição do flutuado e afundado

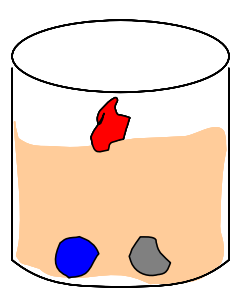

6) Recuperação do líquido denso por filtragem no afundado
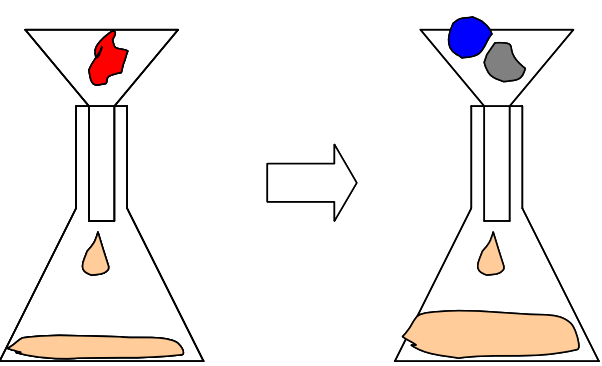

Figura 3.15 - Desenho esquemático que ilustra separação por líquidos densos (ÂNGULO, 2005)

\subsection{CARACTERIZAÇÃO MINERALÓGICA}

Análises mineralógicas por difratometria de raios $\mathrm{X}$ tiveram por objetivo identificar as fases cristalinas presentes nos RCD. Estas foram realizadas em algumas frações granulométricas selecionadas de acordo com a variabilidade encontrada em relação à composição química apresentada, para as frações graúda, miúda e passante em 0,3 mm. Adicionalmente, alguns produtos de separações minerais em líquido denso foram também objeto de análises por DRX.

As análises foram efetuadas através do método do pó mediante difratômetro MPD 1880, marca PHILIPS (Figura 3.16), com tubo de cobre $(\mathrm{CuK \alpha}), 40 \mathrm{kV}$ e $50 \mathrm{~mA}$. A faixa angular de operação foi de 2,5 a $70^{\circ} 2 \theta$, com passo de $0,03^{\circ}$ e tempo de 3 segundo por passo. 


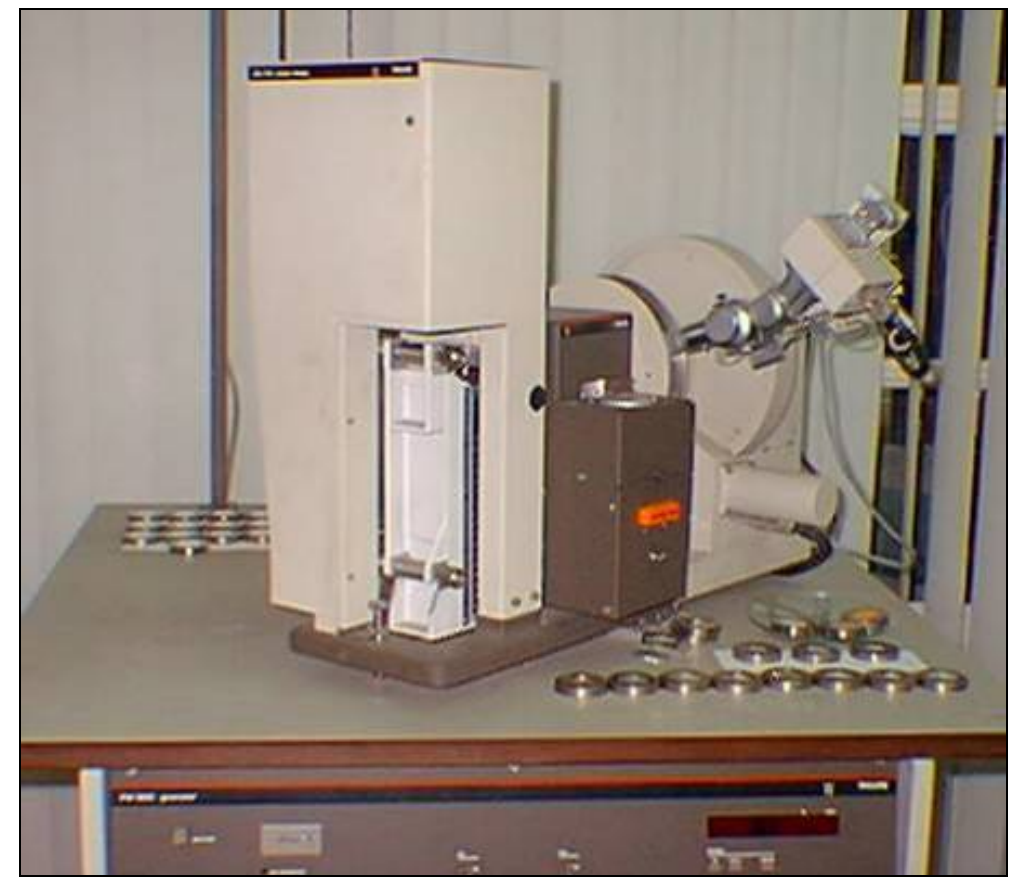

Figura 3.16 - Difratômetro de raios X

A preparação das amostras seguiu procedimento semelhante ao descrito para as análises químicas, porém com a pulverização final realizada em moinho planetário (cerca de $10 \mathrm{~g}$ de amostra), modelo Pulverisette, marca Fritsch (Figura 3.17), seguido de prensagem em anéis (Figura 3.18).

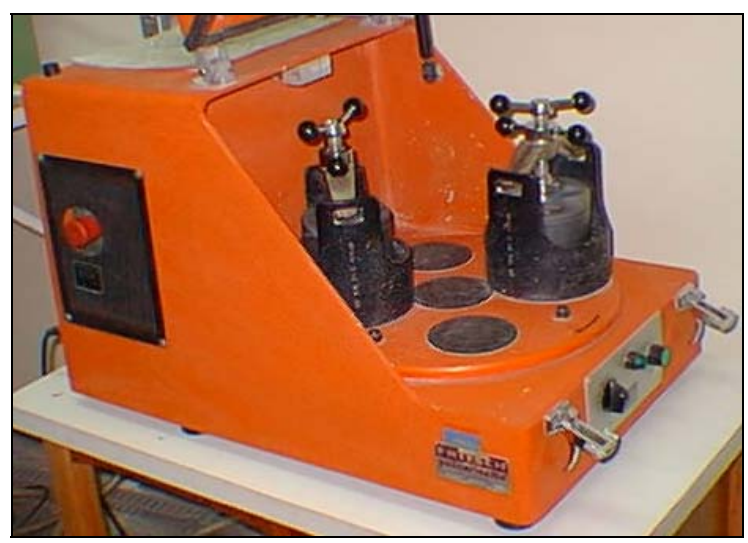

Figura 3.17 - Moinho planetário

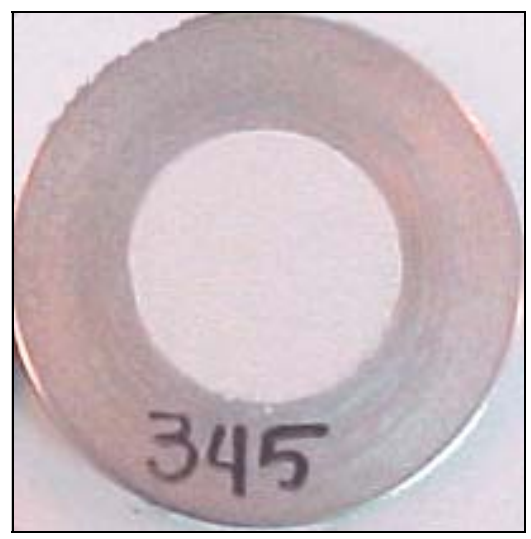

Figura 3.18 - Amostra prensada para DRX

As fases minerais foram identificadas através do programa X'Pert Highscore da PANalytical, utilizando o banco de dados PDF-2 do International Centre for Diffraction Data (ICDD) com base de dados atualizada até 2003. 


\subsection{CARACTERIZAÇÃO MICROESTRUTURAL DE PRODUTOS DE SEPARAÇÕES MINERAIS}

A caracterização microestrutural dos produtos foi efetuada através da conjugação de técnicas de microscopia óptica estereoscópica e de polarização por luz transmitida.

O objetivo foi verificar a influência da separação por densidade na liberação da pasta aderida aos grãos de minerais e não propriamente a identificação das fases minerais e caracterização de suas associações texturais. Para tal foram observados ao microscópio alguns produtos da separação em líquidos densos nos seguintes intervalos de densidade de $1,9-2,2 ; 2,2-2,5$ e maior que $2,5 \mathrm{~g} / \mathrm{cm}^{3}$.

As mesmas amostras foram observadas no microscópio estereoscópico em aumentos de 10 a 30 vezes com luz transmitida (iluminação no sentido amostra-objetiva), com e sem nicóis cruzados; este procedimento foi repetido em maiores magnificações no microscópio de polarização por luz transmitida. Foram também coletadas imagens sob iluminação ultravioleta para uma melhor identificação dos aglomerantes e de suas associações.

Os equipamentos utilizados foram estereomicoscópio Zeiss, modelo SV8, microscópio petrográfico Leica, modelo DMRXP.

\subsection{CARACTERIZAÇÃO DAS PROPRIEDADES FÍSICAS}

\subsubsection{Massa específica}

A determinação da massa específica real das partículas foi realizada através de picnometria com intrusão de gás hélio, sendo esta uma técnica mais rápida e precisa do que a picnometria usualmente efetuada em meio líquido. O hélio é o gás utilizado por ser inerte, podendo ser desprendido no meio ambiente, e por ter baixo número atômico é capaz de penetrar facilmente nos poros da amostra.

As análises foram conduzidas em um equipamento da marca Quantachrome, modelo MUP-SOC (Figura 3.19). 


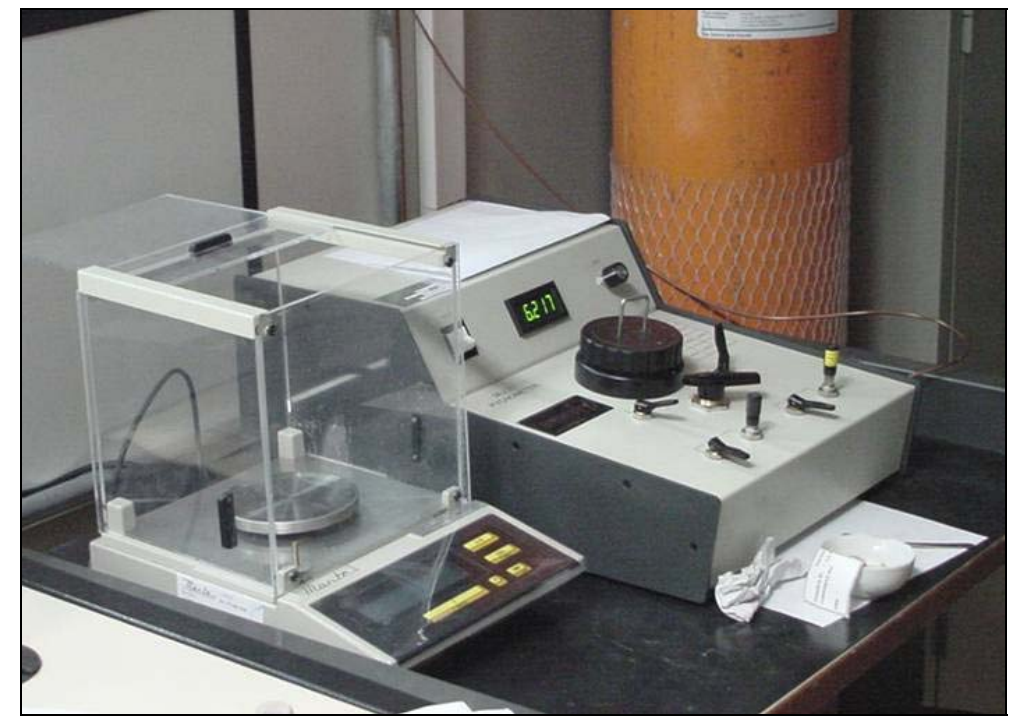

Figura 3.19 - Picnômetro com intrusão de gás hélio

O princípio que rege a picnometria é a determinação indireta do volume ocupado pelos sólidos através de medidas indiretas, no caso a diferença de pressão de gás hélio em uma dada unidade de volume (célula), quando vazia e quando preenchida com o sólido, segundo a Equação 3.2.

$$
V_{s}=V_{c e l}-\left[\left(\frac{P_{1}}{P_{2}}-1\right) \times V_{r}\right] \quad \text { (Equação 3.2) }
$$

em que:

Vs é o volume de sólidos $\left(\mathrm{em} \mathrm{cm}^{3}\right)$;

$V$ cel é o volume da célula de $27,26 \mathrm{~cm}^{3}$;

P1 é o valor da pressão (em psi) determinado após fechamento da célula pressurizada até cerca de 17 psi;

P2 é o valor da pressão (em psi) estabilizado após a abertura da célula;

Vr é o volume residual (em $\mathrm{cm}^{3}$ ) que não pertence à célula;

A picnometria foi conduzida em alíquotas remanescentes dos produtos separados por densidade, estas foram cominuídas em moinho de rolos, marca Furlan modelo S90L4, até que todo o material fosse passante em $1 \mathrm{~mm}$. Aproximadamente $20 \mathrm{~g}$ de cada produto foi seco em estufa a $105^{\circ} \mathrm{C}$, durante 24 horas e depois mantidas em dessecador por 2 horas para se atingir equilíbrio térmico com o ambiente antes de iniciadas as medidas no equipamento. 


\subsubsection{Absorção de água e massa específica aparente}

A absorção de água foi determinada para os agregados graúdos de RCD segundo o método descrito pela norma NBR 9937 (ABNT, 1987) de agregados convencionais.

Segundo esta norma, cada produto deve permanecer imerso em água por 24 horas conforme ilustrado na Figura 3.20a; em seguida, cada partícula é seca com pano até atingir a condição saturada superfície seca (SSS), ou seja, sem umidade superficial. Cada uma destas partículas tem sua massa determinada para a condição de SSS, massa submersa e também a massa seca após $24 \mathrm{~h}$ em estufa a $105^{\circ} \mathrm{C}$. A massa submersa é determinada por uma balança hidrostática conforme apresentado na Figura 3.20b.

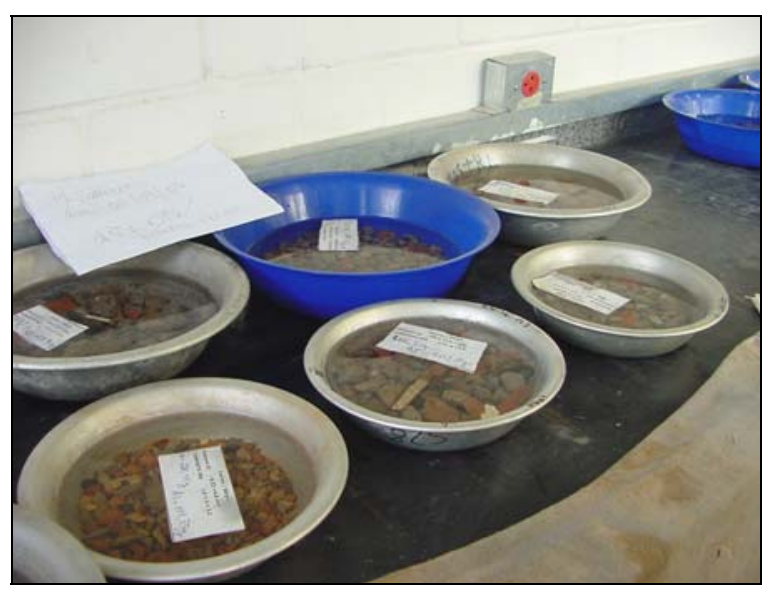

(a)

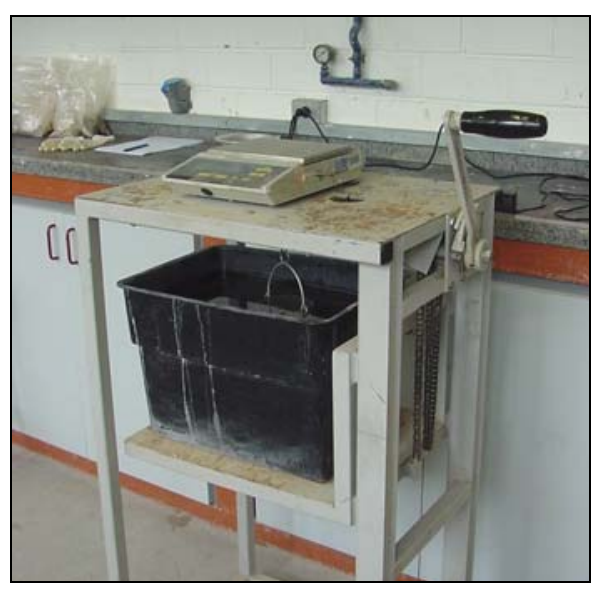

(b)

Figura 3.20 - (a) saturação dos agregados graúdos de RCD reciclados; (b) balança hidrostática para determinação da massa submersa

A determinação da SSS para os agregados miúdos foi realizada através de ensaio descrito pela norma ABNT 9777 (ABNT, 1987). A amostra é saturada em água durante $24 \mathrm{~h}$, em seguida deve ser seca através da utilização de um ventilador com ar quente (Figura 3.21a) até atingir a SSS. Para verificar se a amostra atingiu a condição necessária faz-se um tronco de cone e golpeia-o por 25 vezes, se este desmoronar parcialmente então a amostra está no ponto ideal, como apresentado na Figura 3.21b. Deve-se então determinar a massa na condição de $\operatorname{SSS}\left(\mathrm{M}_{\mathrm{sss}}\right)$ e a massa da amostra depois de seca em estufa $\left(M_{\text {seca }}\right)$. 


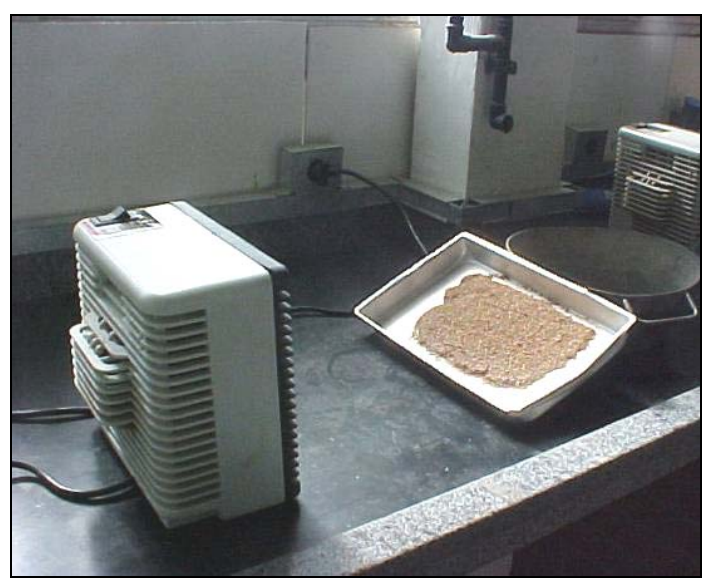

(a)

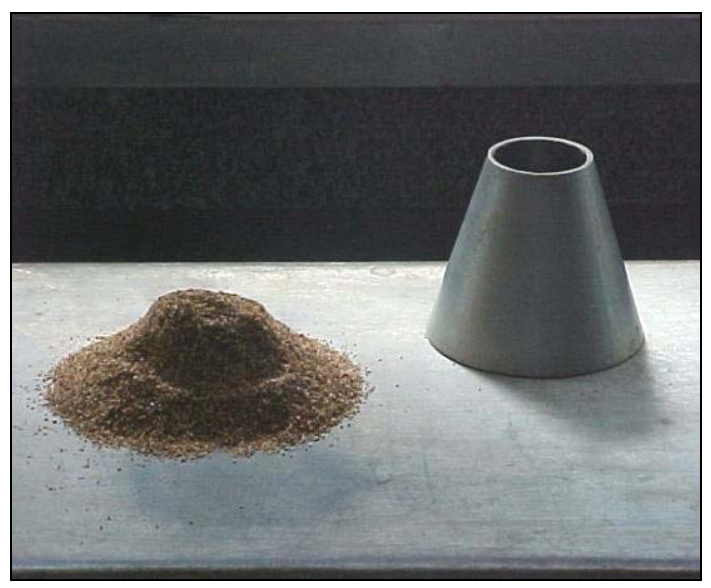

(b)

Figura 3.21 - (a) secagem doa agregados miúdos com ventilador; (b) determinação da condição de SSS

Uma vez conhecida a massa, determinou-se o volume aparente dos agregados miúdos através da medida do volume de água deslocado no frasco de Chapman quando adicionados material sólido na condição de SSS e um volume conhecido de água, conforme NBR 9776 (ABNT, 1987c). O vácuo é um recurso auxiliar recomendado pela NBR 6508 (ABNT, 1982) (Figura 3.22) para retirar bolhas de ar incorporadas à amostra.

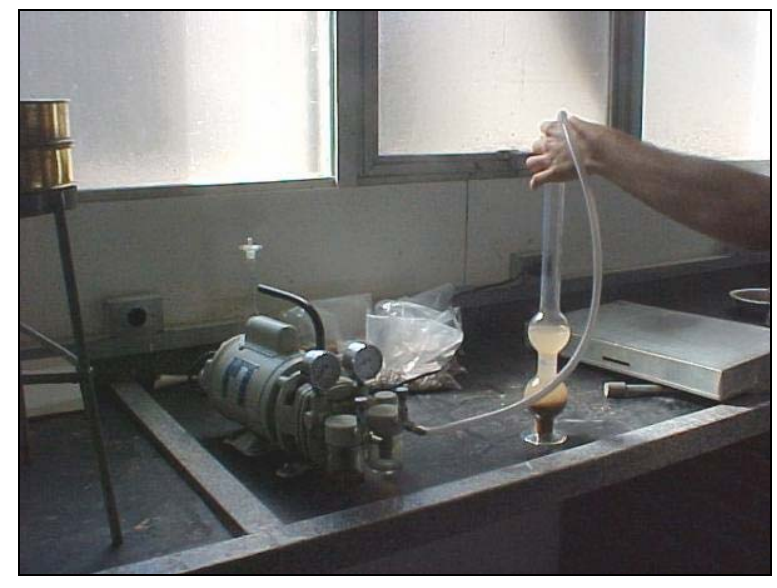

(a)

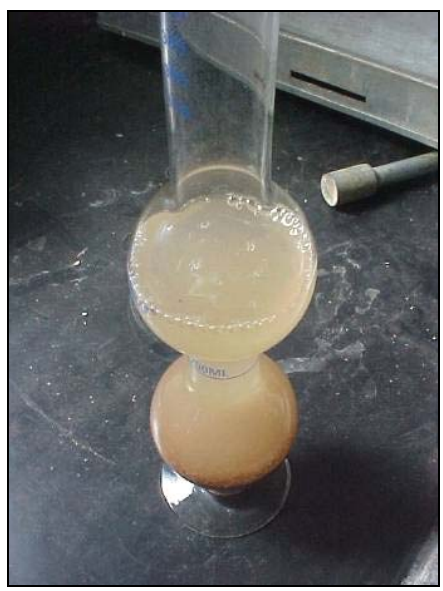

(b)

Figura 3.22 - (a) bomba de vácuo acoplada ao frasco de Chapman (a) e presença de ar incorporado nos agregados miúdos de RCD reciclados (b). 
A absorção de água para os agregados graúdos e miúdos foram determinados segundo a Equação 3.3.

$$
A(\%)=\frac{M_{\text {sss }}-M_{\text {sec } a}}{M_{\sec a}} \times 100 \quad \text { (Equação 3.3) }
$$

em que:

A (\%) é a absorção de água, expressa em porcentagem:

$M_{\text {sss }}$ é a massa (em kg), na condição saturada superfície seca;

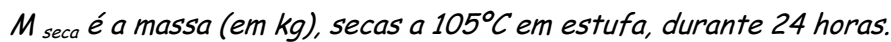

A massa específica aparente dos agregados graúdos foi determinada pela Equação 3.4, para os miúdos, por sua vez, através da Equação 3.5.

$$
\begin{gathered}
M E A_{\text {graúdos }}=\frac{M_{\mathrm{sec} a}}{M_{\text {sss }}-M_{\text {sub }}} \quad\left(\mathrm{kg} / \mathrm{dm}^{3}\right) \\
\operatorname{MEA}_{\text {miúdos }}=\frac{M_{\text {sec } a}}{V_{\text {sólidos }}+V_{\text {água }}} \quad\left(\mathrm{kg} / \mathrm{dm}^{3}\right)
\end{gathered}
$$

em que:

MEA ( $\left.\mathrm{kg} / \mathrm{dm}^{3}\right)$ é a massa específica aparente;

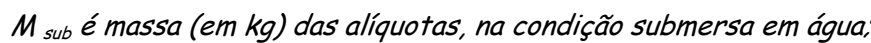

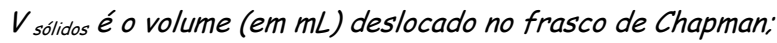

$V_{\text {água }}$ é o volume de água calculado a partir da massa de água absorvida pelo agregado. 


\section{ANÂLISE GRANULOQUÍMICA}

\subsection{ANÁLISE GRANULOMÉTRICA}

A distribuição granulométrica acumulada na fração passante para os produtos "Tal Qual" (TQ) das três amostras estudadas é expressa na Figura 4.1.

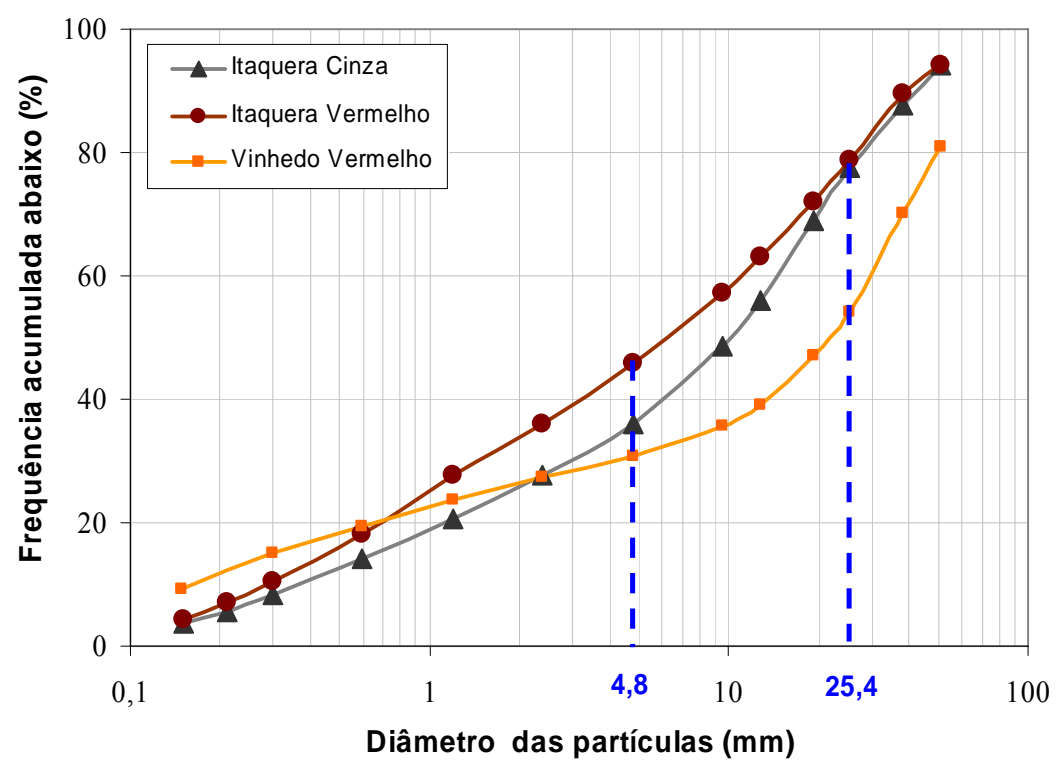

Figura 4.1 - Distribuições granulométricas acumuladas no passante dos produtos “Tal Qual”

As frações granulométricas acima de $25,4 \mathrm{~mm}$ representam aproximadamente $20 \%$ da massa do RCD reciclados de Itaquera (IT-C e IT-V) e 45\% no caso do RCD de Vinhedo (VI-V).

A fração passante em 4,8 mm representa até $40 \%$ em massa dos RCD reciclados; essa magnitude incentiva o desenvolvimento de novos mercados para a fração que atualmente não tem aplicações difundidas. O produto VI-V apresenta a maior quantidade de massa nas frações passante em peneira de abertura de malha $0,6 \mathrm{~mm}$ que os produtos de Itaquera; fato associado a maior eficiência encontrada no peneiramento a úmido, como também à natureza dos finos presentes.

A Figura 4.2 apresenta a distribuição granulométrica acumulada na fração passante para o "Produto Britado - PB" das três amostras estudadas. 


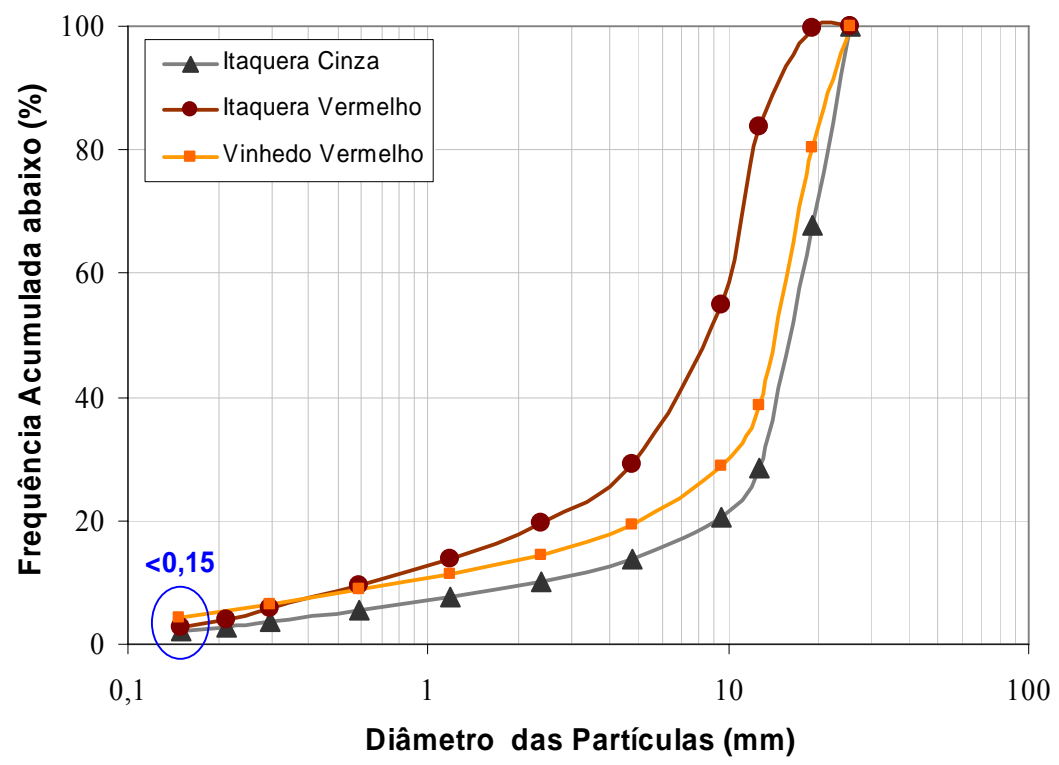

Figura 4.2 - Distribuições granulométricas acumuladas no passante dos PB

A cominuição secundária gera, para praticamente todo o intervalo granulométrico, uma distribuição granulométrica mais fina para IT-V, em virtude do fechamento das mandíbulas; as distribuições de IT-C e VI-V apresentam uma curva semelhante (mesma abertura das mandíbulas), observando-se maior proporção de finos no segundo.

O material passante em $0,15 \mathrm{~mm}$ dos produtos TQ representa entre 5 e $10 \%$, em massa; no PB esse valor é cerca de 5\% para as três amostras, o que mostra que a cominuição secundária não aumentou a proporção de finos.

A Figura 4.3 apresenta o comparativo entre as distribuições granulométricas acumuladas na fração passante para os produtos TQ e PB de cada amostra estudada, sendo (a) IT-C, (b) IT-V, (c) VI-V e (d) todos os produtos.

A britagem secundária de IT-C gera um produto mais grosso do que o material que passou por um único estágio de britagem; para os produtos da classe Vermelha ocorre uma diferenciação bastante acentuada marcada em torno das partículas de 10 mm. Em IT-V a rebritagem gera maior proporção de finos para frações acima de 9,52 mm e menor conteúdo de finos abaixo dessa granulometria; para VI-V a situação é semelhante, porém essa inversão ocorre em 12,7 mm. 


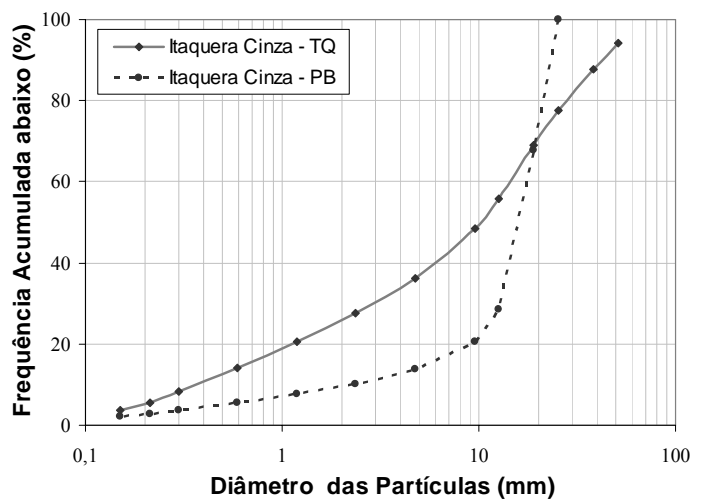

(a) Itaquera Cinza - TQ e PB

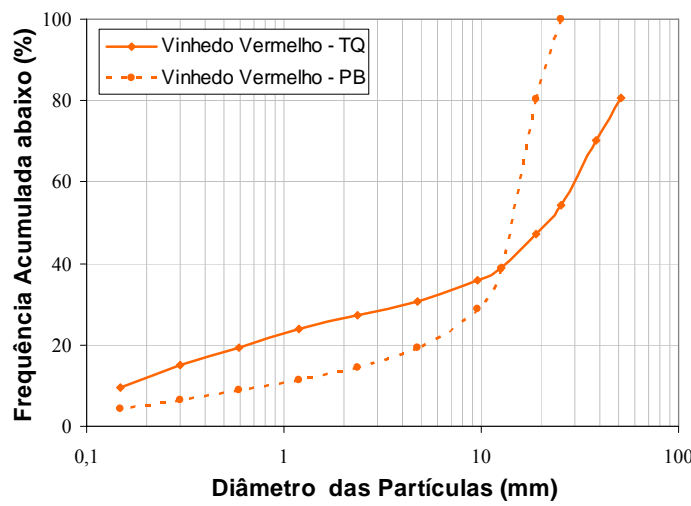

(c) Vinhedo Vermelho - TQ e PB

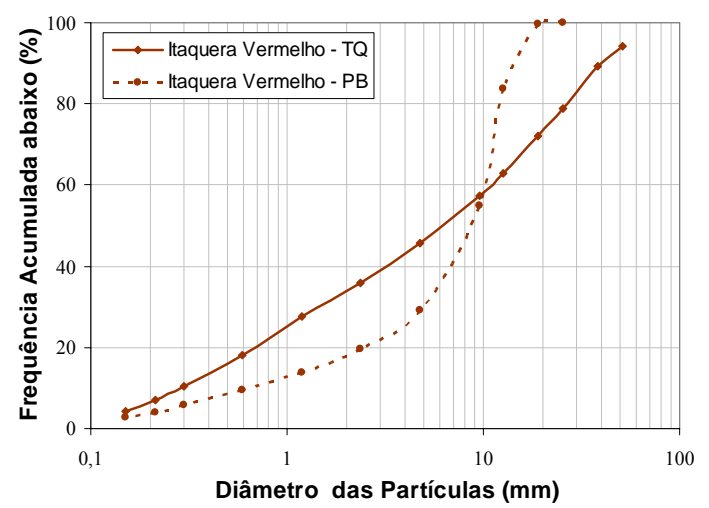

(b) Itaquera Vermelho - TQ e PB

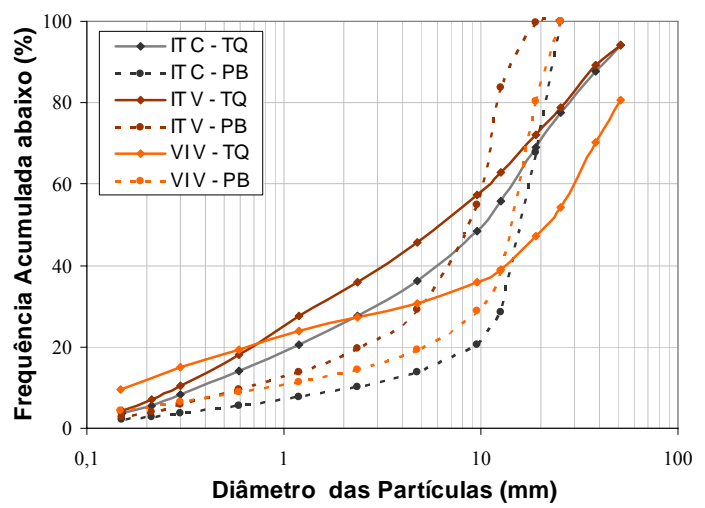

(d) TQ e PB das três amostras

Figura 4.3 - Comparação entre as distribuições granulométricas acumuladas no passante para os produtos TQ e PB das três amostras estudadas

A composição proporcional entre o PB e a fração abaixo de $25,4 \mathrm{~mm}$ do TQ (denominada FBP) gerou a distribuição granulométrica exposta na Figura 4.4. 


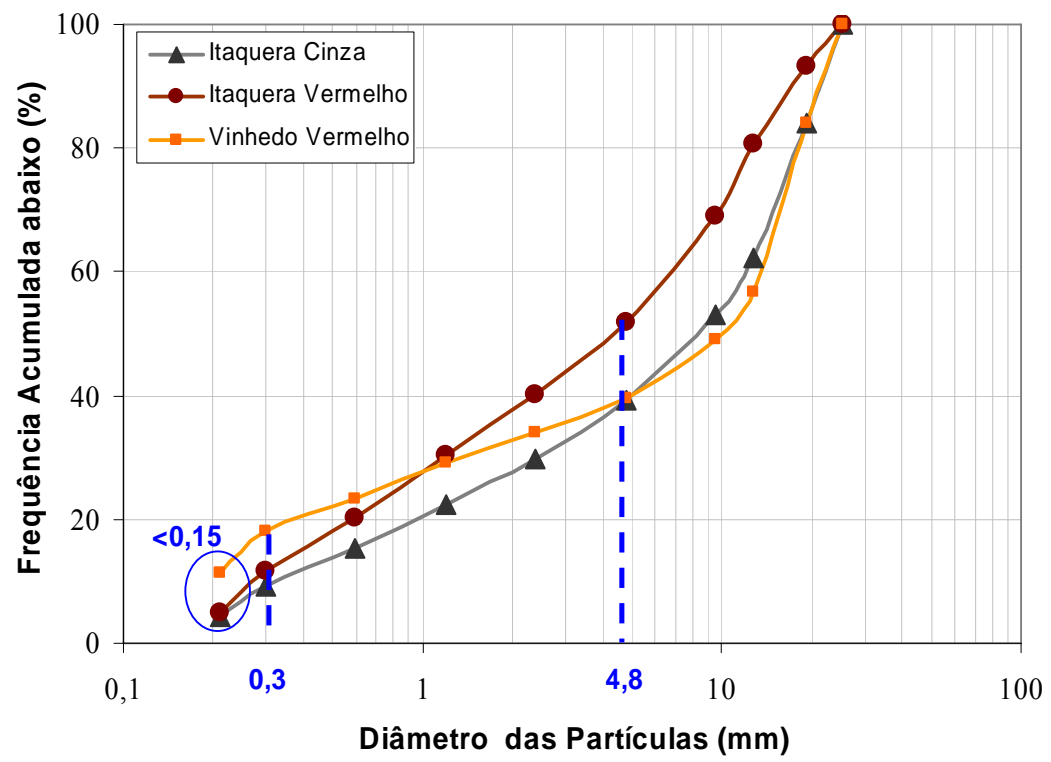

Figura 4.4 - Curva de distribuição granulométrica resultante da composição dos produtos FBP e PB para as amostras estudadas

A fração compreendida entre 4,8 e $0,3 \mathrm{~mm}$ representa até $45 \%$ da massa total de RCD, o que implica em uma necessidade de se desenvolver mercados capazes de absorver esse montante, de forma a tornar sustentável este usina; o material abaixo de $0,15 \mathrm{~mm}$ representa até $15 \%$, sendo que a fração menor que 0,075 (200 malhas Tyler) mm não é utilizada como agregado.

\subsection{COMPOSIÇÃO QUÍMICA POR FRAÇÃO}

\subsubsection{Itaquera cinza}

As Tabelas 4.1 e 4.2 mostram as análises granuloquímicas dos produtos TQ e PB, respectivamente, do agregado cinza de Itaquera, em que o PB representa 22,5\% em massa do TQ. 
Tabela 4.1 - Análise granuloquímica do produto IT-C - TQ

\begin{tabular}{|c|c|c|c|c|c|c|c|c|c|c|c|c|c|c|c|c|c|}
\hline \multirow{2}{*}{$\begin{array}{c}\text { Fração } \\
\text { mm }\end{array}$} & \multicolumn{2}{|c|}{$\%$ Massa } & \multicolumn{11}{|c|}{ Teores (\%) } & \multicolumn{4}{|c|}{ Distribuição (\%) } \\
\hline & retida & acumul. & $\mathrm{SiO}_{2}$ & $\mathrm{Al}_{2} \mathrm{O}_{3}$ & $\mathrm{CaO}$ & $\mathrm{Fe}_{2} \mathrm{O}_{3}$ & $\mathrm{MgO}$ & $\mathrm{Na}_{2} \mathrm{O}$ & $\mathrm{K}_{2} \mathrm{O}$ & $\mathrm{TiO}_{2}$ & $\mathrm{P}_{2} \mathrm{O}_{5}$ & $\mathrm{SO}_{3}$ & PF & $\mathrm{SiO}_{2}$ & $\mathrm{Al}_{2} \mathrm{O}_{3}$ & $\mathrm{CaO}$ & $\mathrm{Fe}_{2} \mathrm{O}_{3}$ \\
\hline$+25,4$ & 22,5 & 22,5 & 66,6 & 8,36 & 9,01 & 2,79 & 1,31 & 1,20 & 2,45 & 0,45 & 0,10 & 0,21 & 8,00 & 22,5 & 21,9 & 23,2 & 22,4 \\
\hline$-25,4+19,1$ & 8,59 & 31,0 & 63,9 & 9,19 & 9,67 & 3,44 & 1,51 & 1,45 & 2,33 & 0,56 & 0,17 & 0,15 & 7,63 & 8,3 & 9,2 & 9,5 & 10,6 \\
\hline$-19,1+12,7$ & 13,0 & 44,0 & 64,8 & 9,10 & 9,59 & 3,41 & 1,48 & 1,46 & 2,34 & 0,56 & 0,17 & 0,30 & 6,49 & 12,7 & 13,8 & 14,3 & 15,8 \\
\hline$-12,7+9,5$ & 7,48 & 51,5 & 68,8 & 8,68 & 7,74 & 2,55 & 1,00 & 1,56 & 2,72 & 0,35 & $<0,10$ & 0,19 & 7,76 & 7,7 & 7,6 & 6,6 & 6,8 \\
\hline$-9,5+4,8$ & 12,5 & 64,0 & 66,0 & 9,48 & 8,59 & 2,71 & 1,27 & 1,37 & 2,65 & 0,44 & 0,14 & 0,23 & 8,20 & 12,4 & 13,8 & 12,3 & 12,1 \\
\hline$-4,8+2,4$ & 8,41 & 72,4 & 66,4 & 8,85 & 8,60 & 2,65 & 1,11 & 1,23 & 2,58 & 0,36 & 0,10 & 0,19 & 8,99 & 8,4 & 8,7 & 8,3 & 8,0 \\
\hline$-2,4+1,2$ & 6,97 & 79,3 & 67,5 & 8,27 & 8,16 & 2,45 & 1,05 & 1,03 & 2,46 & 0,33 & $<0,10$ & 0,20 & 8,39 & 7,1 & 6,7 & 6,5 & 6,1 \\
\hline$-1,2+0,6$ & 6,62 & 86,0 & 71,2 & 7,17 & 7,29 & 2,18 & 0,87 & 0,61 & 2,14 & 0,32 & $<0,10$ & 0,27 & 6,94 & 7,1 & 5,6 & 5,5 & 5,2 \\
\hline$-0,6+0,3$ & 5,81 & 91,8 & 75,6 & 5,84 & 5,95 & 2,00 & 0,69 & 0,37 & 1,64 & 0,26 & $<0,10$ & 0,13 & 7,92 & 6,6 & 4,0 & 4,0 & 4,2 \\
\hline$-0,3+0,15$ & 4,47 & 96,2 & 68,3 & 7,37 & 7,69 & 2,63 & 0,97 & 0,38 & 1,67 & 0,50 & $<0,10$ & $<0,10$ & 10,1 & 4,6 & 3,9 & 3,9 & 4,2 \\
\hline$-0,15$ & 3,77 & 100,0 & 47,8 & 11,1 & 13,5 & 3,56 & 1,77 & 0,47 & 1,79 & 0,66 & 0,18 & 0,31 & 20,0 & 2,7 & 4,9 & 5,8 & 4,8 \\
\hline total & 100,0 & & 66,5 & 8,56 & 8,72 & 2,80 & 1,22 & 1,14 & 2,35 & 0,44 & ... & 0,21 & 8,36 & 100,0 & 200,0 & 100 & 100,0 \\
\hline
\end{tabular}

Tabela 4.2 - Análise granuloquímica do produto IT-C - PB

\begin{tabular}{|c|c|c|c|c|c|c|c|c|c|c|c|c|c|c|c|c|c|}
\hline \multirow{2}{*}{$\begin{array}{c}\text { Fração } \\
\mathrm{mm}\end{array}$} & \multirow{2}{*}{\multicolumn{2}{|c|}{$\begin{array}{c}\% \text { Massa } \\
\text { retida acumul. }\end{array}$}} & \multirow[b]{2}{*}{$\mathrm{SiO}_{2}$} & \multirow[b]{2}{*}{$\mathrm{Al}_{2} \mathrm{O}_{3}$} & \multirow[b]{2}{*}{$\mathrm{CaO}$} & \multicolumn{4}{|c|}{ Teores (\%) } & \multirow[b]{2}{*}{$\mathrm{TiO}_{2}$} & \multirow[b]{2}{*}{$\mathrm{P}_{2} \mathrm{O}_{5}$} & \multirow[b]{2}{*}{$\mathrm{SO}_{3}$} & \multirow[b]{2}{*}{ PF } & \multicolumn{4}{|c|}{ Distribuição (\%) } \\
\hline & & & & & & $\mathrm{Fe}_{2} \mathrm{O}_{3}$ & $\mathrm{MgO}$ & $\mathrm{Na}_{2} \mathrm{O}$ & $\mathrm{K}_{2} \mathrm{O}$ & & & & & $\mathrm{SiO}_{2}$ & $\mathrm{Al}_{2} \mathrm{O}_{3}$ & $\mathrm{CaO}$ & $\mathrm{Fe}_{2} \mathrm{O}_{3}$ \\
\hline$-25,4+19,1$ & 32,3 & 32,3 & 66,6 & 9,30 & 8,48 & 2,79 & 1,25 & 1,50 & 2,87 & 0,41 & 0,12 & 0,12 & 6,70 & 32,3 & 36,0 & 30,4 & 32,4 \\
\hline$-19,1+12,7$ & 39,2 & 71,5 & 66,7 & 8,59 & 8,65 & 2,93 & 1,30 & 1,27 & 2,38 & 0,52 & 0,12 & 0,24 & 8,15 & 39,2 & 40,3 & 37,6 & 41,2 \\
\hline$-12,7+9,5$ & 7,88 & 79,4 & 64,1 & 7,47 & 11,20 & 2,98 & 1,78 & 0,93 & 2,15 & 0,46 & 0,10 & 0,24 & 9,78 & 7,6 & 7,0 & 9,8 & 8,4 \\
\hline$-9,5+4,8$ & 6,77 & 86,2 & 66,6 & 7,63 & 9,46 & 2,68 & 1,28 & 0,87 & 2,42 & 0,40 & 0,10 & 0,33 & 8,39 & 6,8 & 6,2 & 7,1 & 6,5 \\
\hline$-4,8+2,4$ & 3,70 & 89,9 & 67,5 & 7,21 & 9,86 & 2,20 & 1,42 & 0,84 & 2,15 & 0,37 & $<0,10$ & 0,60 & 9,18 & 3,8 & 3,2 & 4,1 & 2,9 \\
\hline$-2,4+1,2$ & 2,42 & 92,3 & 69,6 & 6,53 & 8,46 & 2,41 & 1,17 & 0,67 & 1,92 & 0,36 & $<0,10$ & 0,20 & 8,54 & 2,5 & 1,9 & 2,3 & 2,1 \\
\hline$-1,2+0,6$ & 2,08 & 94,4 & 75,7 & 5,00 & 6,93 & 1,91 & 0,80 & 0,43 & 1,64 & 0,24 & $<0,10$ & $<0,10$ & 6,81 & 2,4 & 1,2 & 1,6 & 1,4 \\
\hline$-0,6+0,3$ & 1,90 & 96,3 & 76,6 & 4,51 & 6,79 & 2,00 & 0,74 & 0,34 & 1,51 & 0,24 & $<0,10$ & $<0,10$ & 6,72 & 2,2 & 1,0 & 1,4 & 1,4 \\
\hline$-0,3+0,15$ & 1,67 & 97,9 & 70,3 & 5,36 & 9,20 & 2,40 & 1,04 & 0,38 & 1,65 & 0,40 & $<0,10$ & 0,12 & 9,14 & 1,8 & 1,1 & 1,7 & 1,4 \\
\hline$-0,15$ & 2,07 & 100,0 & 49,8 & 8,43 & 17,5 & 3,01 & 1,97 & 0,56 & 1,94 & 0,51 & 0,16 & 0,50 & 16,1 & 1,6 & 2,1 & 4,0 & 2,2 \\
\hline total & 100,0 & & 66,6 & 8,36 & 9,01 & 2,79 & 1,31 & 1,20 & 2,45 & 0,45 & 0,10 & & 8,00 & 100 & & & 100,0 \\
\hline
\end{tabular}

Os teores médios de $\mathrm{SiO}_{2}$ e PF são muito semelhantes entre os produtos TQ e PB em todo o intervalo granulométrico; da mesma forma os teores de $\mathrm{Al}_{2} \mathrm{O}_{3}$ são discretamente maiores para as frações do TQ, o inverso do verificado para o $\mathrm{CaO}$. As duas frações mais grossas do PB são responsáveis por uma recuperação superior a $60 \%$ dos principais óxidos (sílica, alumina, $\mathrm{CaO}$ e $\mathrm{Fe}_{2} \mathrm{O}_{3}$ ) face sua grande representatividade em massa.

A Figura 4.5 ilustra a variação composicional dos principais óxidos constituintes dos produtos TQ e PB do agregado reciclado cinza de Itaquera. 

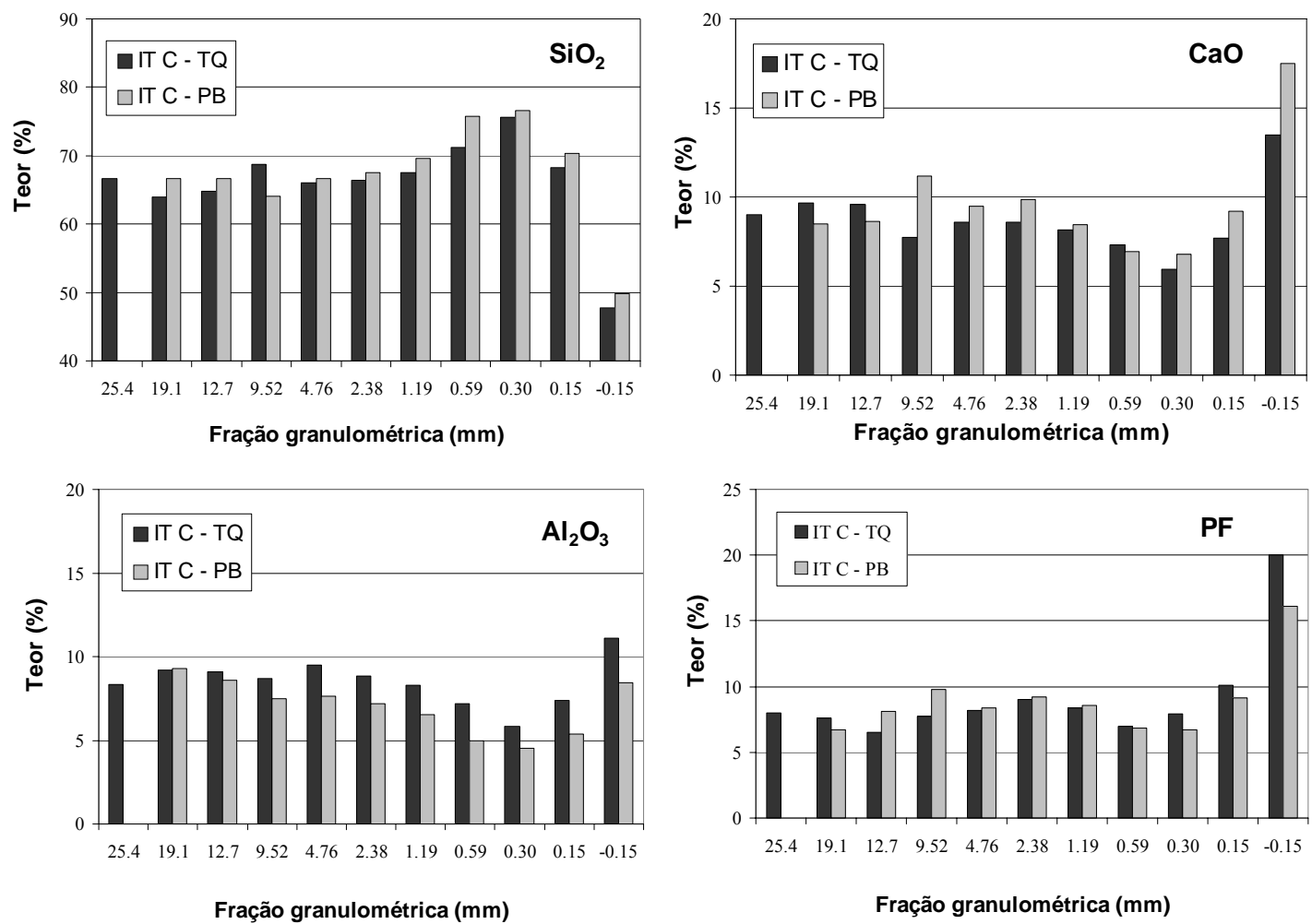

Figura 4.5 - Teores dos óxidos $\mathrm{SiO}_{2}, \mathrm{Al}_{2} \mathrm{O}_{3}, \mathrm{CaO}$ e perda ao fogo por fração granulométrica dos produtos TQ e PB do agregado de $\mathrm{RCD}$ reciclado IT-C

As diferenças observadas entre os teores dos produtos é bastante discreta; somente as frações passantes em 0,15 $\mathrm{mm}$ apresentam teores notoriamente discrepantes em relação às demais frações. Para ambos os produtos os teores de sílica estão entre $60 \mathrm{e}$ $80 \%$ nas frações maiores que $0,15 \mathrm{~mm}$, decrescendo para teores inferiores a $50 \%$ no passante. Já os teores de óxidos de cálcio apresentam um comportamento inverso, situando-se abaixo de $11 \%$ nas frações acima de $0,15 \mathrm{~mm}$ e aumentando para até $17 \%$ no passante; os teores de alumina situam-se entre 5 e $10 \%$ para quase todo o intervalo granulométrico, com discreta redução entre 0,6 e $0,15 \mathrm{~mm}$. A variação da perda ao fogo também é pouco expressiva nas frações acima de $0,15 \mathrm{~mm}$ (entre $5 \mathrm{e}$ $10 \%)$, aumentando significativamente para o passante $(>15 \%)$. 


\subsubsection{Itaquera vermelho}

As Tabelas 4.3 e 4.4 mostram as distribuições granuloquímicas dos produtos TQ e $\mathrm{PB}$, respectivamente, do agregado vermelho de Itaquera, em que o PB representa $21,1 \%$, em massa, do TQ.

Tabela 4.3 - Análise granuloquímica do produto IT-V - TQ

\begin{tabular}{|c|c|c|c|c|c|c|c|c|c|c|c|c|c|c|c|c|c|}
\hline \multirow{3}{*}{$\begin{array}{c}\begin{array}{c}\text { Fração } \\
\mathrm{mm}\end{array} \\
+25,4\end{array}$} & \multirow{2}{*}{\multicolumn{2}{|c|}{$\begin{array}{c}\% \text { Massa } \\
\text { retida acumul. }\end{array}$}} & \multirow{3}{*}{$\frac{\mathrm{SiO}_{2}}{=65,6}$} & \multirow{3}{*}{$\frac{\mathrm{Al}_{2} \mathrm{O}_{3}}{8,51}$} & \multirow{3}{*}{$\frac{\mathrm{CaO}}{9,34}$} & \multirow{3}{*}{$\frac{\mathrm{Fe}_{2} \mathrm{O}_{3}}{3,20}$} & \multicolumn{3}{|c|}{ Teores (\%) } & \multirow[b]{2}{*}{$\mathrm{TiO}_{2}$} & \multirow[b]{2}{*}{$\mathrm{P}_{2} \mathrm{O}_{5}$} & \multirow[b]{2}{*}{$\mathrm{SO}_{3}$} & \multirow[b]{2}{*}{ PF } & \multicolumn{4}{|c|}{ Distribuição (\%) } \\
\hline & & & & & & & $\mathrm{MgO}$ & $\mathrm{Na}_{2} \mathrm{O}$ & $\mathrm{K}_{2} \mathrm{O}$ & & & & & $\mathrm{SiO}_{2}$ & $\mathrm{Al}_{2} \mathrm{O}_{3}$ & $\mathrm{CaO}$ & $\mathrm{Fe}_{2} \mathrm{O}_{3}$ \\
\hline & 21,1 & 21,1 & & & & & 1,52 & 0,95 & 2,36 & 0,38 & 0,07 & 0,26 & 8,28 & 20,7 & 19,2 & 26,8 & 21,3 \\
\hline$-25,4+19,1$ & 6,8 & 27,9 & 68,4 & 11,2 & 5,76 & 3,30 & 0,95 & 1,68 & 3,22 & 0,42 & $<0,10$ & 0,17 & 4,94 & 7,0 & 8,2 & 5,3 & 7,1 \\
\hline$-19,1+12,7$ & 9,1 & 37,0 & 68,7 & 11,0 & 5,70 & 3,20 & 1,09 & 1,85 & 3,02 & 0,42 & 0,10 & 0,27 & 3,63 & 9,3 & 10,6 & 7,0 & 9,2 \\
\hline$-12,7+9,5$ & 5,7 & 42,7 & 66,3 & 10,5 & 6,88 & 3,42 & 1,28 & 1,38 & 2,71 & 0,43 & 0,10 & 0,16 & 6,28 & 5,6 & 6,4 & 5,3 & 6,2 \\
\hline$-9,5+4,8$ & 11,6 & 54,2 & 65,5 & 9,69 & 8,24 & 3,38 & 1,03 & 0,86 & 2,81 & 0,51 & 0,10 & 0,24 & 7,32 & 11,3 & 11,9 & 12,9 & 12,4 \\
\hline$-4,8+2,4$ & 9,8 & 64,0 & 67,6 & 8,51 & 9,29 & 2,52 & 1,39 & 0,95 & 2,53 & 0,34 & $<0,10$ & $<0,10$ & 7,54 & 9,9 & 8,9 & 12,4 & 7,8 \\
\hline$-2,4+1,2$ & 8,4 & 72,4 & 68,6 & 8,78 & 6,45 & 3,19 & 0,81 & 0,47 & 2,25 & 0,50 & $<0,10$ & 0,27 & 7,97 & 8,6 & 7,9 & 7,4 & 8,5 \\
\hline$-1,2+0,6$ & 9,4 & 81,8 & 71,7 & 7,74 & 4,97 & 2,73 & 0,76 & 0,27 & 1,58 & 0,41 & $<0,10$ & 0,17 & 7,47 & 10,1 & 7,8 & 6,4 & 8,1 \\
\hline$-0,6+0,3$ & 7,8 & 89,7 & 71,8 & 7,57 & 4,88 & 2,88 & 0,75 & 0,23 & 1,48 & 0,44 & $<0,10$ & $<0,10$ & 7,73 & 8,4 & 6,3 & 5,2 & 7,1 \\
\hline$-0,3+0,15$ & 6,0 & 95,6 & 65,8 & 9,85 & 6,16 & 3,30 & 1,03 & 0,33 & 1,73 & 0,69 & $<0,10$ & 0,11 & 9,31 & 5,9 & 6,39 & 5,0 & 6,2 \\
\hline$-0,15$ & 4,4 & 100,0 & 48,6 & 13,5 & 10,2 & 4,39 & 1,70 & 0,49 & 1,85 & 0,83 & 0,15 & $<0,10$ & 19,1 & 3,2 & 6,3 & 6,17 & 6,1 \\
\hline total & 100,0 & & 66,9 & 9,34 & 7,34 & 3,16 & 1,15 & 0,88 & 2,36 & 0,46 & $\ldots$ & $\ldots$ & 7,72 & 100,0 & 100 & & 100,0 \\
\hline
\end{tabular}

Tabela 4.4 - Análise granuloquímica do produto IT-V - PB

\begin{tabular}{|c|c|c|c|c|c|c|c|c|c|c|c|c|c|c|c|c|c|}
\hline \multirow{3}{*}{$\begin{array}{c}\begin{array}{c}\text { Fração } \\
\mathrm{mm}\end{array} \\
-25,4+19,1\end{array}$} & \multirow{2}{*}{\multicolumn{2}{|c|}{$\begin{array}{c}\% \text { Massa } \\
\text { retida acumul. }\end{array}$}} & \multirow{3}{*}{$\begin{array}{c}\mathrm{SiO}_{2} \\
-\end{array}$} & \multirow{3}{*}{$\begin{array}{c}\mathrm{Al}_{2} \mathrm{O}_{3} \\
-\end{array}$} & \multirow{3}{*}{$\begin{array}{c}\mathrm{CaO} \\
-\end{array}$} & \multicolumn{4}{|c|}{ Teores (\%) } & \multirow[b]{2}{*}{$\mathrm{TiO}_{2}$} & \multirow[b]{2}{*}{$\mathrm{P}_{2} \mathrm{O}_{5}$} & \multirow[b]{2}{*}{$\mathrm{SO}_{3}$} & \multirow[b]{2}{*}{ PF } & \multicolumn{4}{|c|}{ Distribuição (\%) } \\
\hline & & & & & & $\mathrm{Fe}_{2} \mathrm{O}_{3}$ & $\mathrm{MgO}$ & $\mathrm{Na}_{2} \mathrm{O}$ & $\mathrm{K}_{2} \mathrm{O}$ & & & & & $\mathrm{SiO}_{2}$ & $\mathrm{Al}_{2} \mathrm{O}_{3}$ & $\mathrm{CaO}$ & $\mathrm{Fe}_{2} \mathrm{O}_{3}$ \\
\hline & $\star$ & - & & & & - & - & - & - & - & - & - & - & - & - & - & - \\
\hline$-19,1+12,7$ & 16,4 & 16,4 & 68,5 & 8,15 & 8,57 & 3,48 & 1,43 & 0,84 & 2,30 & 0,38 & $<0,10$ & 0,28 & 6,99 & 17,1 & 15,7 & 15,1 & 17,8 \\
\hline$-12,7+9,5$ & 28,6 & 45,0 & 64,3 & 9,65 & 9,41 & 3,22 & 1,87 & 1,35 & 2,53 & 0,40 & 0,13 & 0,33 & 7,73 & 28,1 & 32,5 & 28,6 & 28,8 \\
\hline$-9,5+4,8$ & 25,8 & 70,8 & 65,7 & 8,34 & 9,86 & 2,97 & 1,45 & 0,93 & 2,46 & 0,37 & 0,10 & 0,27 & 8,04 & 25,7 & 25,2 & 27,2 & 23,9 \\
\hline$-4,8+2,4$ & 9,7 & 80,5 & 63,7 & 9,72 & 7,11 & 3,36 & 0,98 & 0,84 & 2,47 & 0,46 & $<0,10$ & 0,41 & 9,24 & 9,4 & 11,0 & 7,4 & 10,2 \\
\hline$-2,4+1,2$ & 5,7 & 86,1 & 69,1 & 7,49 & 8,90 & 2,66 & 1,18 & 0,70 & 2,32 & 0,29 & $<0,10$ & 0,11 & 7,51 & 6,0 & 5,0 & 5,4 & 4,7 \\
\hline$-1,2+0,6$ & 4,3 & 90,4 & 71,1 & 5,95 & 8,42 & 3,13 & 1,23 & 0,48 & 1,84 & 0,25 & $<0,10$ & $<0,10$ & 7,80 & 4,7 & 3,0 & 3,9 & 4,2 \\
\hline$-0,6+0,3$ & 3,8 & 94,3 & 70,1 & 5,32 & 8,49 & 3,84 & 1,33 & 0,35 & 1,67 & 0,26 & $<0,10$ & $<0,10$ & 9,01 & 4,1 & 2,4 & 3,5 & 4,6 \\
\hline$-0,3+0,15$ & 3,0 & 97,3 & 65,2 & 6,65 & 11,3 & 3,09 & 1,69 & 0,46 & 1,95 & 0,45 & $<0,10$ & $<0,10$ & 10,2 & 3,0 & 2,4 & 3,7 & 2,2 \\
\hline$-0,15$ & 2,8 & 100,0 & 46,0 & 8,81 & 17,5 & 3,37 & 2,28 & 0,59 & 2,07 & 0,50 & 0,16 & $<0,10$ & 19,6 & 1,9 & 2,9 & 5,2 & 2,9 \\
\hline total & 100,0 & & 65,6 & 8,51 & 9,34 & 3,20 & 1,52 & 0,95 & 2,36 & 0,38 & $\ldots$ & $\ldots$ & 8,28 & 100,0 & 100 & & 100,0 \\
\hline
\end{tabular}

*A britagem secundária resultou em quantidade inexpressiva de massa na peneira de abertura 19,1 mm (<1\%)

Os teores médios de $\mathrm{SiO}_{2}$ e PF são muito semelhantes entre os produtos TQ e PB em todo o intervalo granulométrico; os teores de alumina são discretamente maiores para as frações do TQ, o inverso do ocorre com o $\mathrm{CaO}$. 
A Figura 4.6 ilustra a variação composicional dos principais óxidos constituintes dos produtos TQ e PB do agregado reciclado vermelho de Itaquera.
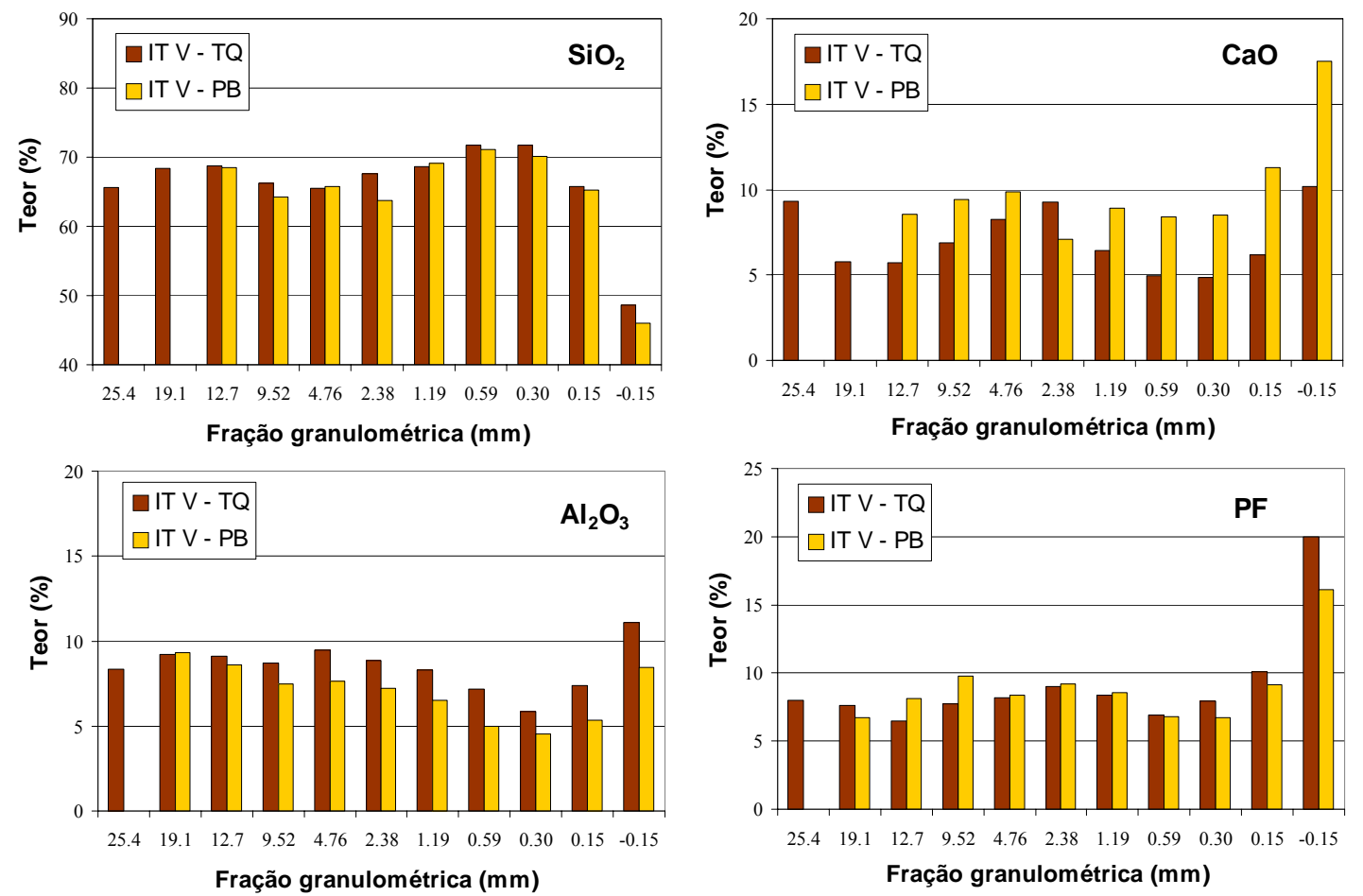

Figura 4.6 -Teores dos óxidos $\mathrm{SiO}_{2}, \mathrm{Al}_{2} \mathrm{O}_{3}, \mathrm{CaO}$ e perda ao fogo por fração granulométrica para os produtos TQ e PB do agregado de RCD reciclado IT-V

De maneira análoga à IT-C, os teores médios de $\mathrm{SiO}_{2}$ e $\mathrm{PF}$ são muito semelhantes para os produtos TQ e PB em todo o intervalo granulométrico avaliado, com sutil incremento de PF na fração $-19,1+9,5 \mathrm{~mm}$ do $\mathrm{PB}$. Os teores de $\mathrm{Al}_{2} \mathrm{O}_{3}$ e $\mathrm{CaO}$ variam em ordem inversa, os teores de $\mathrm{CaO}$ são mais elevados no $\mathrm{PB}$ em todo o intervalo granulométrico, exceto na fração $-4,8+2,4 \mathrm{~mm}$, ao passo que para a alumina ocorre o inverso, porém com menor variação de valores.

Observa-se um comportamento diferenciado na fração passante em $0,15 \mathrm{~mm}$, indicando uma redução significativa nos teores de $\mathrm{SiO}_{2}$ acompanhada de um expressivo aumento na perda ao fogo, $\mathrm{Al}_{2} \mathrm{O}_{3}$ e de $\mathrm{CaO}$. 


\subsubsection{Vinhedo vermelho}

As Tabelas 4.5 e 4.6 mostram as distribuições granuloquímicas dos produtos TQ e $\mathrm{PB}$, respectivamente, do agregado vermelho de Vinhedo, em que o PB representa $45,8 \%$ em massa do TQ.

Tabela 4.5 - Análise granuloquímica do produto VI-V - TQ

\begin{tabular}{|c|c|c|c|c|c|c|c|c|c|c|c|c|c|c|c|c|c|}
\hline \multirow{3}{*}{$\begin{array}{c}\begin{array}{c}\text { Fração } \\
\mathrm{mm}\end{array} \\
+25,4\end{array}$} & \multirow{2}{*}{\multicolumn{2}{|c|}{$\begin{array}{c}\% \text { Massa } \\
\text { retida acumul. }\end{array}$}} & \multirow{3}{*}{$\begin{array}{r}\mathrm{SiO}_{2} \\
67,3\end{array}$} & \multirow{3}{*}{$\begin{array}{r}\mathrm{Al}_{2} \mathrm{O}_{3} \\
10,3\end{array}$} & \multirow{3}{*}{$\frac{\mathrm{CaO}}{7,24}$} & \multirow{3}{*}{$\frac{\mathrm{Fe}_{2} \mathrm{O}_{3}}{3,34}$} & \multicolumn{3}{|c|}{ Teores (\%) } & \multirow[b]{2}{*}{$\mathrm{TiO}_{2}$} & \multirow[b]{2}{*}{$\mathrm{P}_{2} \mathrm{O}_{5}$} & \multirow[b]{2}{*}{$\mathrm{SO}_{3}$} & \multirow[b]{2}{*}{ PF } & \multicolumn{4}{|c|}{ Distribuição (\%) } \\
\hline & & & & & & & $\mathrm{MgO}$ & $\mathrm{Na}_{2} \mathrm{O}$ & $\mathrm{K}_{2} \mathrm{O}$ & & & & & $\mathrm{SiO}_{2}$ & $\mathrm{Al}_{2} \mathrm{O}_{3}$ & $\mathrm{CaO}$ & $\mathrm{Fe}_{2} \mathrm{O}_{3}$ \\
\hline & 45,8 & 45,8 & & & & & 1,34 & 0,88 & 2,39 & 0,49 & $<0,10$ & 0,29 & 6,43 & 44,3 & 46,6 & 55,4 & 48,2 \\
\hline$-25,4+19,1$ & 7,02 & 52,8 & 71,8 & 9,70 & 6,76 & 1,87 & 0,79 & 0,45 & 1,54 & 0,51 & $<0,10$ & 0,33 & 6,73 & 7,3 & 6,7 & 7,9 & 4,1 \\
\hline$-19,1+12,7$ & 8,15 & 60,9 & 71,1 & 10,2 & 5,06 & 3,07 & 0,92 & 0,71 & 1,89 & 0,55 & $<0,10$ & 0,21 & 6,92 & 8,3 & 8,2 & 6,9 & 7,9 \\
\hline$-12,7+9,5$ & 3,29 & 64,2 & 69,5 & 10,2 & 6,08 & 2,97 & 0,97 & 0,77 & 1,99 & 0,58 & $<0,10$ & 1,06 & 7,55 & 3,3 & 3,3 & 3,3 & 3,1 \\
\hline$-9,5+4,8$ & 4,96 & 69,2 & 69,4 & 11,2 & 5,55 & 3,01 & 1,06 & 1,43 & 2,22 & 0,51 & $<0,10$ & 0,27 & 6,12 & 5,0 & 5,5 & 4,6 & 4,7 \\
\hline$-4,8+2,4$ & 3,46 & 72,6 & 69,0 & 10,4 & 5,95 & 3,43 & 1,12 & 0,83 & 1,93 & 0,54 & $<0,10$ & 0,28 & 6,33 & 3,4 & 3,6 & 3,4 & 3,7 \\
\hline$-2,4+1,2$ & 3,56 & 76,2 & 78,4 & 7,17 & 3,43 & 2,55 & 0,60 & 0,50 & 1,50 & 0,38 & $<0,10$ & 0,13 & 4,72 & 4,0 & 2,5 & 2,1 & 2,9 \\
\hline$-1,2+0,6$ & 4,45 & 80,6 & 85,1 & 4,71 & 2,15 & 2,08 & 0,37 & 0,17 & 1,07 & 0,23 & $<0,10$ & $<0,10$ & 3,06 & 5,5 & 2,1 & 1,6 & 2,9 \\
\hline$-0,6+0,3$ & 4,34 & 85,0 & 85,1 & 4,30 & 1,92 & 2,13 & 0,33 & 0,12 & 1,03 & 0,23 & $<0,10$ & $<0,10$ & 3,75 & 5,3 & 1,8 & 1,4 & 2,9 \\
\hline$-0,3+0,15$ & 5,65 & 90,6 & 82,1 & 5,48 & 2,60 & 2,33 & 0,46 & 0,17 & 1,20 & 0,40 & $<0,10$ & 0,12 & 4,14 & 6,7 & 3,1 & 2,5 & 4,2 \\
\hline$-0,15$ & 9,36 & 100,0 & 51,8 & 18,0 & 6,92 & 5,21 & 1,30 & 0,26 & 1,98 & 0,91 & 0,20 & 0,37 & 14,00 & 7,0 & 16,6 & 10,8 & 15,4 \\
\hline total & 100,0 & & 69,5 & 10,1 & 5,98 & 3,17 & 1,07 & 0,68 & 1,99 & 0,51 & $<0,10$ & 0,28 & 6,76 & 100,0 & 100, & 100 & 100,0 \\
\hline
\end{tabular}

Tabela 4.6 - Análise granuloquímica do produto VI-V - PB

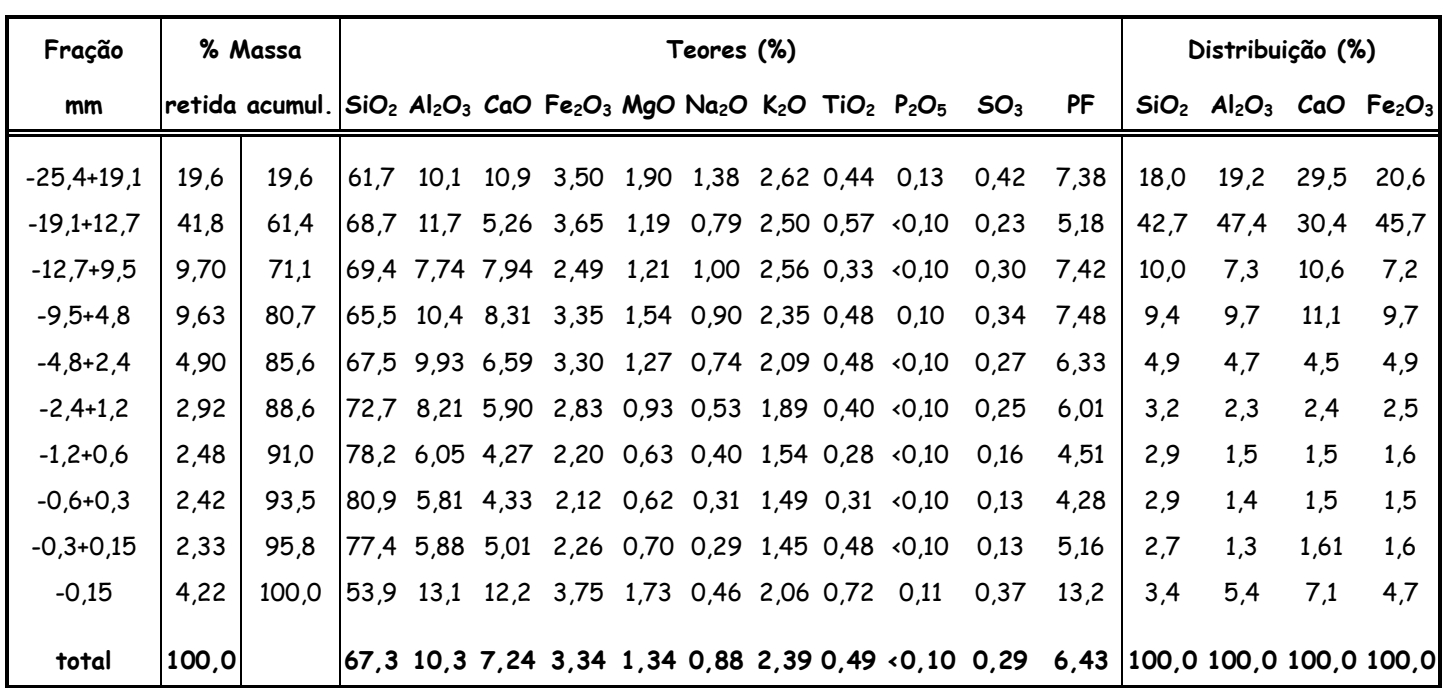

Os teores médios de $\mathrm{SiO}_{2}$, alumina e $\mathrm{PF}$ e são muito semelhantes entre os produtos TQ e PB para o intervalo granulométrico acima de $0,15 \mathrm{~mm}$; os teores de $\mathrm{CaO}$ são discretamente maiores para as frações do PB. Na fração passante o teor de alumina é maior para o TQ e o teor de $\mathrm{CaO}$ é maior para o $\mathrm{PB}$. 
A Figura 4.7 ilustra a variação composicional dos principais óxidos constituintes dos produtos TQ e PB do agregado reciclado vermelho de Itaquera.
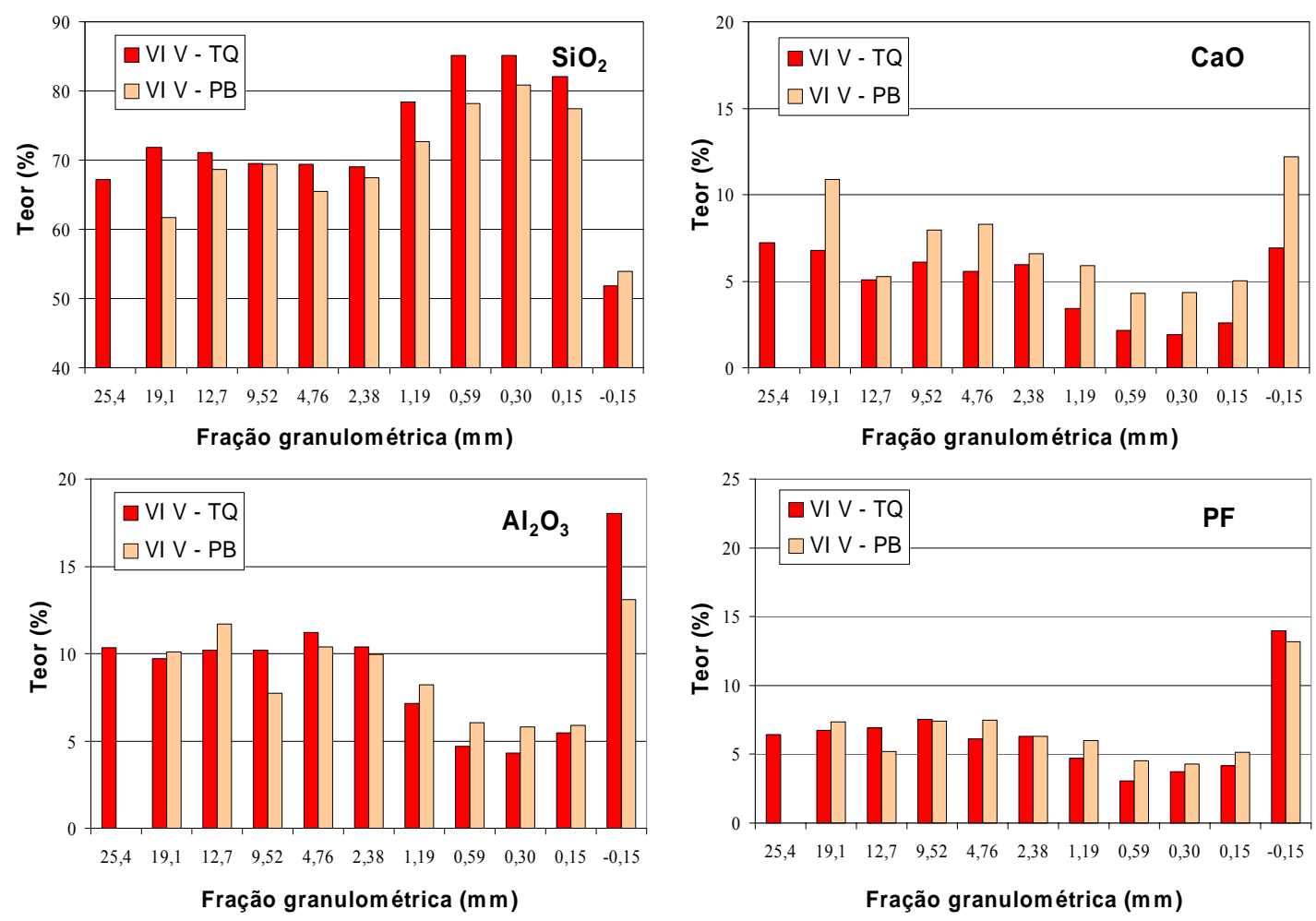

Figura 4.7 - Teores dos óxidos $\mathrm{SiO}_{2}, \mathrm{Al}_{2} \mathrm{O}_{3}, \mathrm{CaO}$ e perda ao fogo por fração granulométrica para os produtos TQ e PB do agregado de RCD reciclado VI-V

A composição química é semelhante à dos RCD de Itaquera, cujos principais óxidos são sílica, alumina e $\mathrm{CaO}$. Os teores médios de cada óxido são semelhantes na granulometria, sendo que há considerável aumento nos teores de $\mathrm{CaO}, \mathrm{Al}_{2} \mathrm{O}_{3}$ e de $\mathrm{PF}$ para a fração passante em $0,15 \mathrm{~mm}$, aliada à expressiva redução de sílica. Além disso, os teores de $\mathrm{SiO}_{2}$ nas frações abaixo de $12,7 \mathrm{~mm}$ do produto TQ são ligeiramente superiores aos das respectivas frações do PB, assim como os teores de $\mathrm{CaO}$ são inferiores. 


\subsubsection{Sumário da composição química dos produtos por fração granulométrica $(F B P+P B)$}

As Tabelas 4.7 a 4.9 mostram as análises granuloquímicas dos RCD reciclados de IT-C, IT-V e VI-V resultantes das composições ponderadas entre os produtos FBP e PB.

Tabela 4.7 - Análise granuloquímica da composição FBP+PB do RCD IT-C

\begin{tabular}{|c|c|c|c|c|c|c|c|c|c|c|c|c|c|c|c|c|c|}
\hline \multirow{2}{*}{$\begin{array}{c}\text { Fração } \\
\text { mm }\end{array}$} & \multirow{2}{*}{\multicolumn{2}{|c|}{$\begin{array}{c}\text { \% Massa } \\
\text { retida acumul. }\end{array}$}} & \multicolumn{11}{|c|}{ Teores (\%) } & \multicolumn{4}{|c|}{ Distribuição (\%) } \\
\hline & & & $\mathrm{SiO}_{2}$ & $\mathrm{Al}_{2} \mathrm{O}_{3}$ & $\mathrm{CaO}$ & $\mathrm{Fe}_{2} \mathrm{O}_{3}$ & $\mathrm{MgO}$ & $\mathrm{Na}_{2} \mathrm{O}$ & $\mathrm{K}_{2} \mathrm{O}$ & $\mathrm{TiO}_{2}$ & $\mathrm{P}_{2} \mathrm{O}_{5}$ & $\mathrm{SO}_{3}$ & PF & $\mathrm{SiO}_{2}$ & $\mathrm{Al}_{2} \mathrm{O}_{3}$ & $\mathrm{CaO}$ & $\mathrm{Fe}_{2} \mathrm{O}_{3}$ \\
\hline$-25,4+19,1$ & 15,8 & 15,8 & 65,1 & 9,24 & 9,13 & 3,14 & 1,39 & 1,47 & 2,58 & 0,49 & 0,15 & 0,14 & 7,20 & 15,5 & 17,1 & 16,6 & 17,8 \\
\hline$-19,1+12,7$ & 21,8 & 37,6 & 65,6 & 8,89 & 9,21 & 3,22 & 1,41 & 1,38 & 2,36 & 2,36 & 0,15 & 0,28 & 7,16 & 21,5 & 22,6 & 23,0 & 25,0 \\
\hline$-12,7+9,5$ & 9,3 & 46,9 & 67,9 & 8,45 & 8,40 & 2,63 & 1,15 & 1,44 & 2,61 & 2,61 & $\ldots$ & 0,20 & 8,15 & 9,4 & 9,1 & 8,9 & 8,7 \\
\hline$-9,5+4,8$ & 14,0 & 60,9 & 66,1 & 9,28 & 8,68 & 2,71 & 1,27 & 1,32 & 2,62 & 2,62 & 0,14 & 0,24 & 8,22 & 13,9 & 15,1 & 13,9 & 13,5 \\
\hline$-4,8+2,4$ & 9,2 & 70,1 & 66,5 & 8,70 & 8,71 & 2,61 & 1,14 & 1,19 & 2,54 & 2,54 & $\ldots$ & 0,23 & 9,01 & 9,2 & 9,4 & 9,2 & 8,6 \\
\hline$-2,4+1,2$ & 7,5 & 77,6 & 67,7 & 8,14 & 8,18 & 2,45 & 1,06 & 1,00 & 2,42 & 2,42 & $\ldots$ & 0,20 & 8,40 & 7,6 & 7,1 & 7,0 & 6,6 \\
\hline$-1,2+0,6$ & 7,1 & 84,7 & 71,5 & 7,03 & 7,27 & 2,16 & 0,87 & 0,60 & 2,11 & 2,11 & $\ldots$ & $\ldots$ & 6,93 & 7,6 & 5,8 & 5,9 & 5,5 \\
\hline$-0,6+0,3$ & 6,2 & 90,9 & 75,7 & 5,75 & 6,01 & 2,00 & 0,69 & 0,37 & 1,63 & 1,63 & $\ldots$ & $\ldots$ & 7,84 & 7,1 & 4,2 & 4,3 & 4,5 \\
\hline$-0,3+0,15$ & 4,8 & 95,8 & 68,5 & 7,21 & 7,81 & 2,61 & 0,98 & 0,38 & 1,67 & 1,67 & $\ldots$ & $\ldots$ & 10,0 & 5,0 & 4,1 & 4,3 & 4,5 \\
\hline$-0,15$ & 4,2 & 100,0 & 48,0 & 10,8 & 13,9 & 3,50 & 1,79 & 0,48 & 1,81 & 1,81 & 0,18 & 0,33 & 19,6 & 3,1 & 5,3 & 6,8 & 5,3 \\
\hline total & 100,0 & & 66,5 & 8,56 & 8,72 & 2,80 & 1,22 & 1,14 & 2,35 & 2,02 & & $\ldots$ & 8,36 & 100,0 & 100 & 100, & 100,0 \\
\hline
\end{tabular}

Tabela 4.8 - Análise granuloquímica da composição FBP+PB do RCD IT-V

\begin{tabular}{|c|c|c|c|c|c|c|c|c|c|c|c|c|c|c|c|c|c|}
\hline \multirow{3}{*}{$\begin{array}{c}\begin{array}{c}\text { Fração } \\
\mathrm{mm}\end{array} \\
-25,4+12,7\end{array}$} & \multirow{2}{*}{\multicolumn{2}{|c|}{$\begin{array}{c}\% \text { Massa } \\
\text { retida acumul. }\end{array}$}} & \multirow{3}{*}{$\frac{\mathrm{SiO}_{2}}{68,6}$} & \multirow{3}{*}{$\frac{\mathrm{Al}_{2} \mathrm{O}_{3}}{10,6}$} & \multirow{3}{*}{$\frac{\mathrm{CaO}}{6,24}$} & \multirow{3}{*}{$\frac{\mathrm{Fe}_{2} \mathrm{O}_{3}}{3,29}$} & \multicolumn{3}{|c|}{ Teores (\%) } & \multirow[b]{2}{*}{$\mathrm{TiO}_{2}$} & \multirow[b]{2}{*}{$\mathrm{P}_{2} \mathrm{O}_{5}$} & \multirow[b]{2}{*}{$\mathrm{SO}_{3}$} & \multirow[b]{2}{*}{ PF } & \multicolumn{4}{|c|}{ Distribuição (\%) } \\
\hline & & & & & & & $\mathrm{MgO}$ & $\mathrm{Na}_{2} \mathrm{O}$ & $\mathrm{K}_{2} \mathrm{O}$ & & & & & $\mathrm{SiO}_{2}$ & $\mathrm{Al}_{2} \mathrm{O}_{3}$ & $\mathrm{CaO}$ & $\mathrm{Fe}_{2} \mathrm{O}_{3}$ \\
\hline & 19,3 & 19,3 & & & & & 1,10 & 1,61 & 2,96 & 0,41 & $\ldots$ & 0,24 & 4,69 & 19,8 & 21,8 & 16,4 & 20,1 \\
\hline$-12,7+9,5$ & 11,7 & 31,1 & 65,3 & 10,1 & 8,18 & 3,32 & 1,58 & 1,36 & 2,62 & 0,41 & 0,12 & 0,25 & 7,03 & 11,4 & 12,6 & 13,1 & 12,3 \\
\hline$-9,5+4,8$ & 17,0 & 48,0 & 65,6 & 9,26 & 8,76 & 3,25 & 1,16 & 0,88 & 2,70 & 0,47 & 0,10 & 0,25 & 7,55 & 16,7 & 16,8 & 20,3 & 17,5 \\
\hline$-4,8+2,4$ & 11,9 & 59,9 & 66,9 & 8,72 & 8,91 & 2,66 & 1,32 & 0,93 & 2,52 & 0,36 & $\ldots$ & $\ldots$ & 7,83 & 11,9 & 11,1 & 14,4 & 10,0 \\
\hline$-2,4+1,2$ & 9,6 & 69,5 & 68,7 & 8,62 & 6,76 & 3,12 & 0,86 & 0,50 & 2,26 & 0,47 & $\ldots$ & 0,25 & 7,91 & 9,8 & 8,8 & 8,8 & 9,5 \\
\hline$-1,2+0,6$ & 10,3 & 79,8 & 71,6 & 7,58 & 5,28 & 2,77 & 0,80 & 0,29 & 1,60 & 0,40 & $\ldots$ & $\ldots$ & 7,50 & 11,1 & 8,4 & 7,4 & 9,0 \\
\hline$-0,6+0,3$ & 8,6 & 88,5 & 71,6 & 7,36 & 5,22 & 2,97 & 0,80 & 0,24 & 1,50 & 0,42 & $\ldots$ & $\ldots$ & 7,85 & 9,2 & 6,8 & 6,1 & 8,1 \\
\hline$-0,3+0,15$ & 6,6 & 95,1 & 65,7 & 9,54 & 6,66 & 3,28 & 1,09 & 0,34 & 1,75 & 0,67 & $\ldots$ & $\ldots$ & 9,40 & 6,5 & 6,7 & 6,0 & 6,9 \\
\hline$-0,15$ & 5,0 & 100,0 & 48,3 & 12,9 & 11,1 & 4,27 & 1,77 & 0,50 & 1,88 & 0,79 & 0,15 & $\ldots$ & 19,2 & 3,6 & 6,9 & 7,5 & 6,7 \\
\hline total & 100,0 & & 66,9 & 9,34 & 7,34 & 3,16 & 1,15 & 0,88 & 2,36 & 0,46 & $\ldots$ & $\ldots$ & 7,72 & 100,0 & $100, C$ & 100. & 100,0 \\
\hline
\end{tabular}


Tabela 4.9 - Análise granuloquímica da composição FBP+PB do RCD VI-V

\begin{tabular}{|c|c|c|c|c|c|c|c|c|c|c|c|c|c|c|c|c|c|}
\hline \multirow{3}{*}{$\begin{array}{c}\begin{array}{c}\text { Fração } \\
m m\end{array} \\
-25,4+19,1\end{array}$} & \multirow{2}{*}{\multicolumn{2}{|c|}{$\begin{array}{c}\% \text { Massa } \\
\text { retida acumul. }\end{array}$}} & \multirow{3}{*}{$\begin{array}{r}\mathrm{SiO}_{2} \\
66,1\end{array}$} & \multirow{3}{*}{$\begin{array}{r}\mathrm{Al}_{2} \mathrm{O}_{3} \\
9,92\end{array}$} & \multirow{3}{*}{$\frac{\mathrm{CaO}}{9,08}$} & \multirow{3}{*}{$\frac{\mathrm{Fe}_{2} \mathrm{O}_{3}}{2,78}$} & \multicolumn{3}{|c|}{ Teores (\%) } & \multirow[b]{2}{*}{$\mathrm{TiO}_{2}$} & \multirow[b]{2}{*}{$\mathrm{P}_{2} \mathrm{O}_{5}$} & \multirow[b]{2}{*}{$\mathrm{SO}_{3}$} & \multirow[b]{2}{*}{ PF } & \multicolumn{4}{|c|}{ Distribuição (\%) } \\
\hline & & & & & & & $\mathrm{MgO}$ & $\mathrm{Na}_{2} \mathrm{O}$ & $\mathrm{K}_{2} \mathrm{O}$ & & & & & $\mathrm{SiO}_{2}$ & $\mathrm{Al}_{2} \mathrm{O}_{3}$ & $\mathrm{CaO}$ & $\mathrm{Fe}_{2} \mathrm{O}_{3}$ \\
\hline & 16,0 & 16,0 & & & & & 1,41 & 0,97 & 2,15 & 0,47 & $\ldots$ & 0,38 & 7,09 & 15,2 & 16,2 & 24,3 & 14,2 \\
\hline$-19,1+12,7$ & 27,3 & 43,3 & 69,4 & 10,1 & 5,20 & 3,37 & 1,11 & 0,77 & 2,32 & 0,56 & $\ldots$ & 0,22 & 5,70 & 27,3 & 28,2 & 23,7 & 29,3 \\
\hline$-12,7+9,5$ & 7,7 & 51,0 & 69,4 & 11,1 & 7,15 & 3,36 & 1,11 & 0,90 & 2,32 & 0,44 & $\ldots$ & 0,62 & 7,48 & 7,7 & 8,7 & 9,2 & 8,3 \\
\hline$-9,5+4,8$ & 9,4 & 60,4 & 67,6 & 9,57 & 6,85 & 2,77 & 1,29 & 1,18 & 2,28 & 0,50 & $\ldots$ & 0,30 & 6,76 & 9,1 & 9,1 & 10,7 & 8,2 \\
\hline$-4,8+2,4$ & 5,7 & 66,1 & 68,4 & 10,4 & 6,20 & 3,40 & 1,18 & 0,79 & 1,99 & 0,52 & $\ldots$ & 0,28 & 6,33 & 5,6 & 6,0 & 5,9 & 6,2 \\
\hline$-2,4+1,2$ & 4,9 & 71,0 & 76,8 & 7,92 & 4,10 & 2,75 & 0,69 & 0,51 & 1,61 & 0,39 & $\ldots$ & 0,16 & 5,07 & 5,4 & 4,0 & 3,4 & 4,3 \\
\hline$-1,2+0,6$ & 5,6 & 76,5 & 83,7 & 5,42 & 2,58 & 2,23 & 0,42 & 0,22 & 1,17 & 0,24 & $\ldots$ & $\ldots$ & 3,35 & 6,7 & 3,1 & 2,4 & 4,0 \\
\hline$-0,6+0,3$ & 5,4 & 82,0 & 84,2 & 4,66 & 2,41 & 2,14 & 0,39 & 0,16 & 1,12 & 0,25 & $\ldots$ & $\ldots$ & 3,86 & 6,6 & 2,6 & 2,2 & 3,7 \\
\hline$-0,3+0,15$ & 6,7 & 88,7 & 81,4 & 5,53 & 2,98 & 2,30 & 0,50 & 0,19 & 1,24 & 0,41 & $\ldots$ & 0,12 & 4,30 & 7,9 & 3,8 & 3,3 & 4,9 \\
\hline$-0,15$ & 11,3 & 100,0 & 52,2 & 15,9 & 7,82 & 4,71 & 1,37 & 0,29 & 1,99 & 0,88 & 0,18 & 0,37 & 13,9 & 8,5 & 18,3 & 14,8 & 16,9 \\
\hline total & 100,0 & & 69,5 & 9,81 & 5,98 & 3,14 & 1,07 & 0,68 & 1,99 & 0,51 & & $\ldots$ & 6,76 & 100,0 & 100, & 100,0 & 100,0 \\
\hline
\end{tabular}

Os teores médios de sílica, alumina, $\mathrm{CaO}$ e $\mathrm{Fe}_{2} \mathrm{O}_{3}$ são semelhantes para os três tipos de RCD reciclados analisados. As recuperações observadas estão diretamente relacionadas a porcentagem em massa retida nas frações já que os teores distribuemse de forma mais ou menos uniforme no intervalo granulométrico, sendo que entre 50 e $60 \%$ estão concentrados na fração graúda.

A Figura 4.8 ilustra comparativamente os teores de $\mathrm{SiO}_{2}, \mathrm{CaO}, \mathrm{Al}_{2} \mathrm{O}_{3}$ e P.F. resultante da união proporcional dos produtos $\mathrm{FBP}+\mathrm{PB}$ para as três amostras estudadas (composição para produtos britados abaixo de 25,4 mm). 

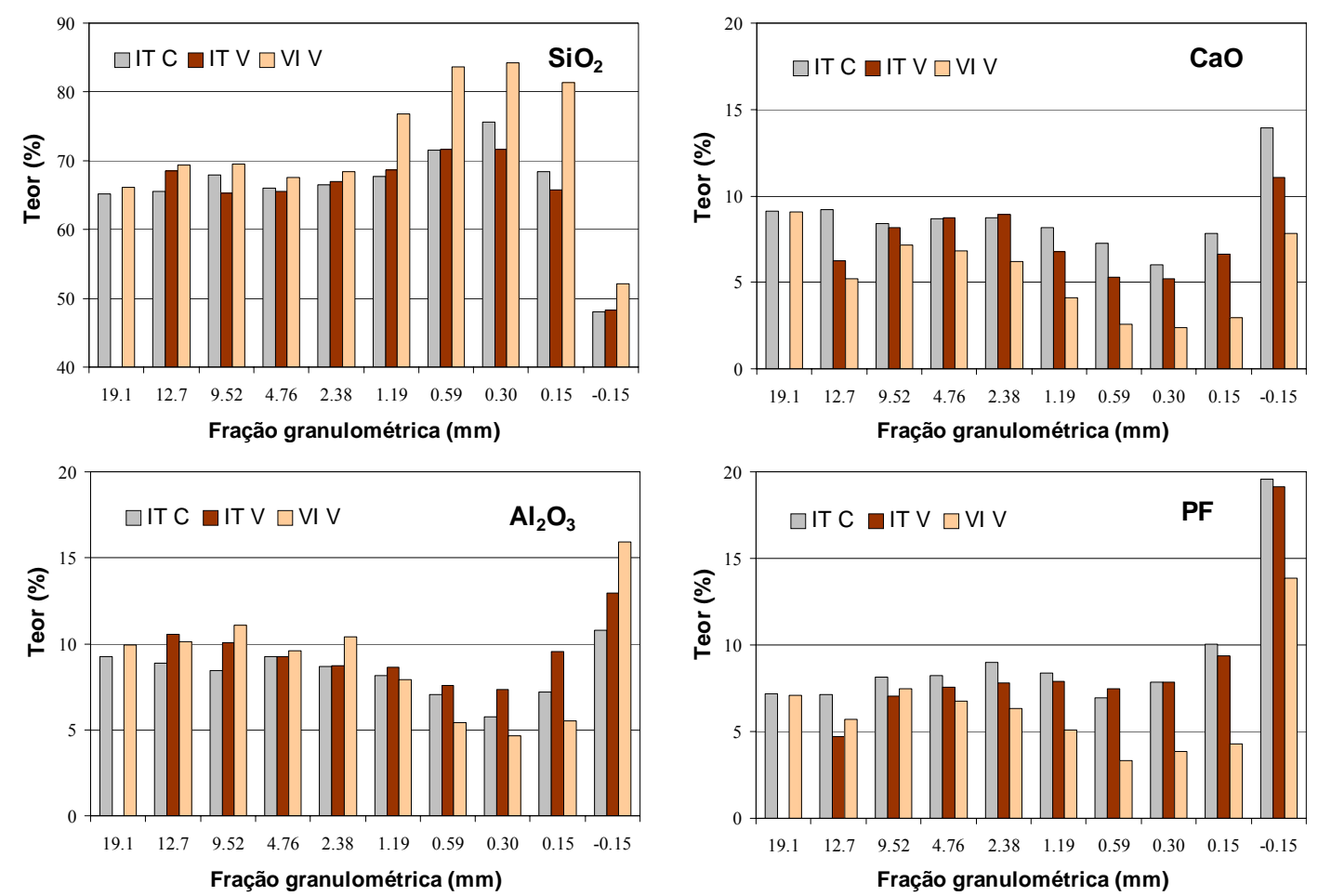

Figura 4.8 - Teores dos óxidos $\mathrm{SiO}_{2}, \mathrm{Al}_{2} \mathrm{O}_{3}$, $\mathrm{CaO}$ e perda ao fogo por fração granulométrica dos produtos FBP+PB dos agregados de RCD reciclados de IT-C, IT-V e VI-V

Os principais óxidos presentes nos agregados de $\mathrm{RCD}$ são $\mathrm{SiO}_{2}$, de 65 a $85 \%$ nas frações acima de $0,15 \mathrm{~mm}$, decrescendo significativamente para valores próximos a $50 \%$ no passante; $\mathrm{Al}_{2} \mathrm{O}_{3}$ (4 a 18\%) e $\mathrm{CaO}$ ( 1 a $18 \%$ ), com enriquecimento nas frações extremas.

Os teores dos agregados de Itaquera são muito semelhantes nos intervalos granulométricos, mostrando que a classificação em tipos cinza e vermelho não é seletiva do ponto de vista químico. A dispersão nos teores é mais acentuada quando se compara a composição química dos agregados de Itaquera e Vinhedo, ou seja, os teores dos óxidos analisados são essencialmente influenciados pela origem do RCD.

Do ponto de vista químico, somente os óxidos de sódio e potássio $\left(\mathrm{Na}_{2} \mathrm{O}\right.$ e $\left.\mathrm{K}_{2} \mathrm{O}\right)$, quando solúveis, podem prejudicar a utilização destes agregados de RCD na construção civil no quesito durabilidade, uma vez que podem causar fenômenos de eflorescência e colaborar com reação expansiva de álcali-sílica reativa em componentes a base de cimento ao longo do tempo. Como os teores de álcalis totais bem como os de óxido de ferro ultrapassam 1\% deve-se investigar a solubilidade 
destes para melhor avaliar o emprego desse material como agregado (QUARCIONI et al., 2003).

A sílica, alumina e óxido de cálcio são provenientes dos diversos tipos de silicatos oriundos da pasta de cimento endurecida, dos agregados naturais e de cerâmicas branca ou vermelha. O óxido de cálcio está associado ao aglomerante (pasta de cimento endurecida, cal, gesso etc) presente em componentes construtivos já que quase a totalidade dos agregados é de origem ígnea. Tal situação não será válida para regiões que utilizam agregados de rocha calcária, pois as composições químicas serão significativamente diferentes.

A perda ao fogo varia de 4 a 20\% estando essencialmente relacionada à liberação da água de constituição e gás carbônico dos silicatos de cálcio hidratado, cal hidratada ou carbonatos, liberação de água dos argilominerais provenientes dos solos, cerâmicas queimadas abaixo de $500^{\circ} \mathrm{C}$ e de rochas naturais como granitos e feldspatos (KLEIN; HURBURT, 1937), assumindo-se que não se tenha água de constituição em cerâmicas queimadas acima de $500^{\circ} \mathrm{C}$ e em rochas naturais.

A Figura 4.9 mostra que a perda ao fogo é proporcional aos teores de $\mathrm{CaO}$ e alumina e inversamente proporcional aos teores de sílica, demonstrando que está relacionada à perda de água e do $\mathrm{CO}_{2}$ do aglomerante como também da argila.

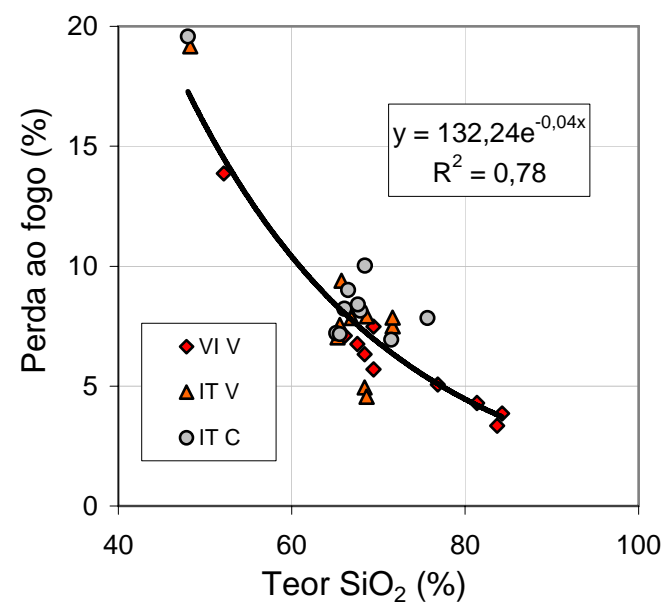

(a)

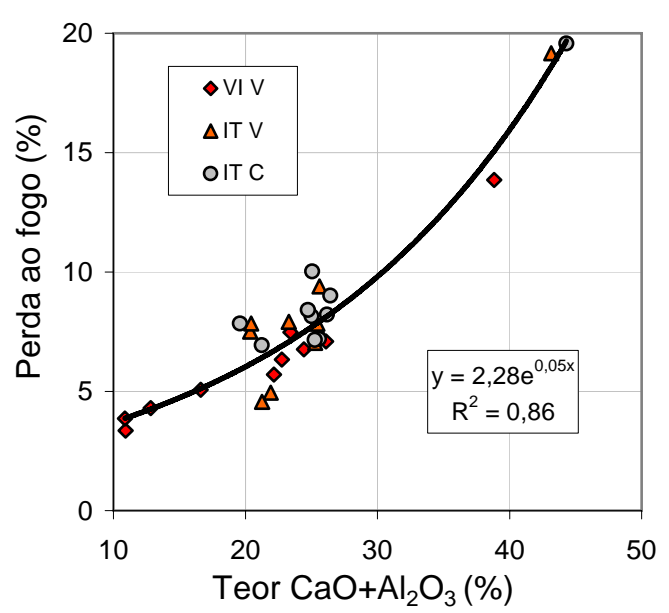

(b)

Figura 4.9 - Relação entre os teores de sílica (a), alumina e óxido de cálcio (b) com a perda ao fogo 
Os teores de sílica, por sua vez, são inversamente proporcionais à soma dos teores de alumina e $\mathrm{CaO}$ conforme ilustrado na Figura 4.10.

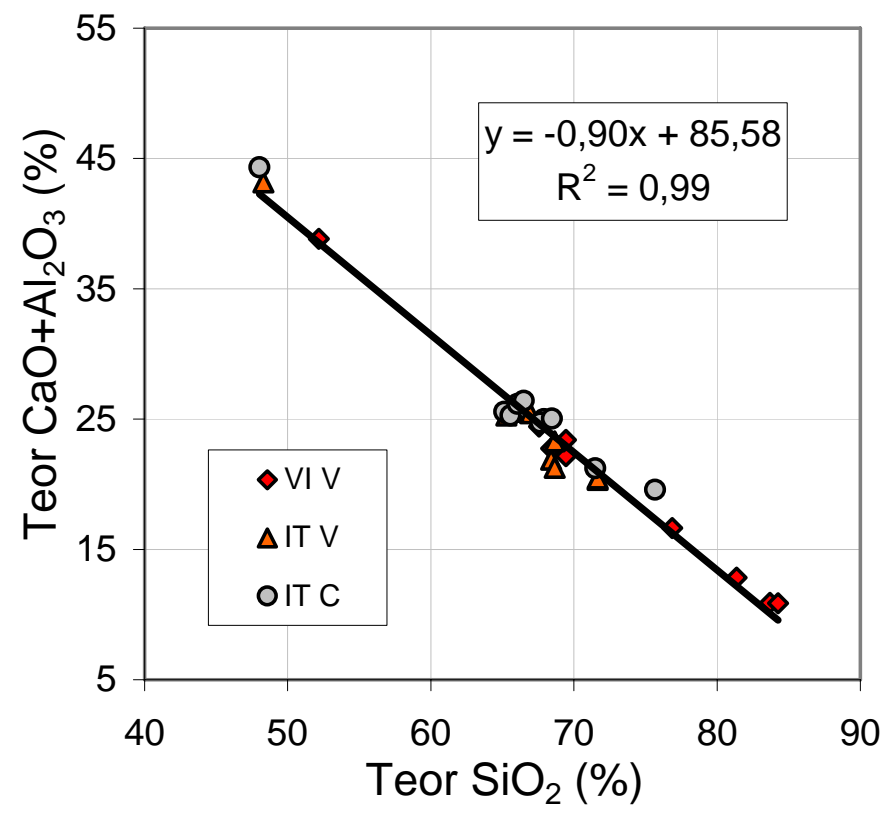

Figura 4.10 - Relação entre os teores de sílica, alumina e + óxido de cálcio com a perda ao fogo

É possível ainda estabelecer uma correlação linear inversa entre a soma de sílica, alumina e óxido de ferro, que representa principalmente os silicatos das rochas naturais e cerâmicas, com a soma dos teores de cálcio e perda ao fogo, que representam indiretamente os aglomerantes e argilominerais (Figura 4.11). Sendo assim, quanto maior a proporção de rochas naturais e cerâmicas no material, menores os teores de aglomerantes e argilominerais.

A relação entre os teores de $\mathrm{CaO}$ e sílica, por sua vez, demonstram que o agregado cinza é mais rico em cálcio do que os agregados vermelhos, devendo o cálcio estar associado a aglomerantes hidratados ou carbonatados (Figura 4.12). 


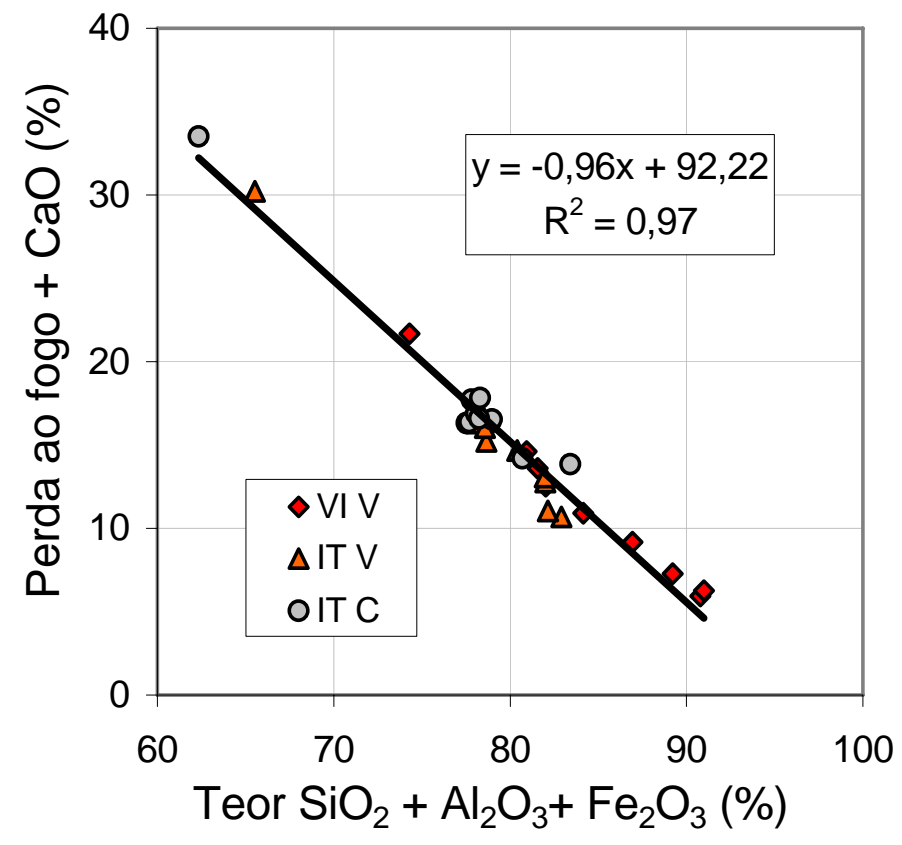

Figura 4.11 - Correlação entre os teores de $\mathrm{SiO}_{2}+\mathrm{Al}_{2} \mathrm{O}_{3}+\mathrm{Fe}_{2} \mathrm{O}_{3}$ e $\mathrm{CaO}+\mathrm{PF}$ (rochas naturais + cerâmicas versus argilominerais + aglomerantes)

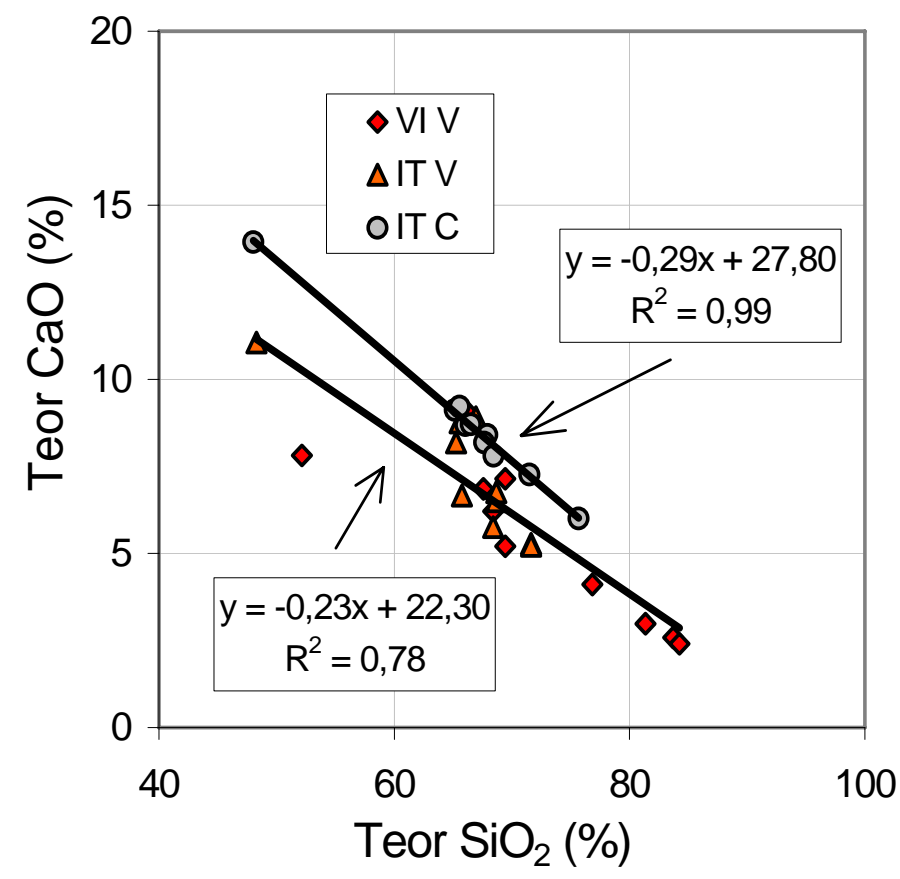

Figura 4.12 - Relação entre os teores de sílica e óxido de cálcio para os três agregados estudados 


\subsubsection{Análises de sais solúveis}

As análises de sais solúveis foram realizadas por Ângulo (ÂNGULO, 2005), cujos resultados serão aqui referenciados.

Algumas amostras foram selecionadas para ensaios adicionais para determinação do teor de sais, cloretos e sulfatos solúveis nos agregados de RCD reciclados. As análises foram conduzidas no IPT de acordo com as diretrizes gerais de Quarcioni (QUARCIONI et al, 2003).

De acordo com os resultados obtidos, as três amostras analisadas apresentaram teores inferiores a $1 \%$ de sulfatos total, impossibilitando a análise desse tipo de influência. Embora os teores de álcalis totais $\left(\mathrm{Na}_{2} \mathrm{O}\right.$ e $\left.\mathrm{K}_{2} \mathrm{O}\right)$ e $\mathrm{Fe}_{2} \mathrm{O}_{3}$ sejam considerados elevados, os teores de íons solúveis ( $\mathrm{Na}, \mathrm{K}, \mathrm{Ca}, \mathrm{Mg}, \mathrm{Cl}-, \mathrm{SO}^{4-}$ ) (Tabela 4.10) são baixos e, portanto, não apresentam risco no uso destes materiais como agregados, não sendo relevante, portanto, analisar a natureza dessa influência (ÂNGULO, 2005).

Tabela 4.10 - Teores de íons solúveis (ÂNGULO, 2005)

\begin{tabular}{|c|c|c|c|c|c|c|}
\hline \multirow{2}{*}{ Amostra } & \multicolumn{7}{|c|}{ Teores (ppm) } \\
\cline { 2 - 7 } & $\mathrm{Na}$ & $\mathrm{K}$ & $\mathrm{Ca}$ & $\mathrm{Mg}$ & Sais solúveis & $\mathbf{S O}_{4}^{-2}$ \\
\hline \hline & & & & & & \\
IT-C graúdo & 58 & 129 & 578 & 2 & 0,52 & 551 \\
IT-C miúdo & 62 & 131 & 241 & 1 & 0,29 & 613 \\
IT-V graúdo & 72 & 66 & 231 & 6 & 0,31 & 464 \\
IT-V miúdo & 186 & 95 & 180 & 5 & 0,28 & 808 \\
VI-V graúdo & 32 & 61 & 353 & 20 & 0,32 & 767 \\
VI-V miúdo & 23 & 34 & 107 & 25 & 0,19 & 371 \\
\hline
\end{tabular}




\section{SEPARAÇÃO EM LÍQUIDOS DENSOS}

Através das separações minerais em líquidos densos foram determinadas as curvas de separabilidade mineral para seis frações granulométricas (entre 25,4 e $0,3 \mathrm{~mm}$ ) do produto composto $\mathrm{FBP}+\mathrm{PB}$.

\subsection{CURVAS DE SEPARABILIDADE}

\subsubsection{Itaquera cinza}

A Tabela 5.1 apresenta a distribuição em massa por fração granulométrica para cada intervalo de densidade dos agregados IT-C; a Figura 5.1, por sua vez, mostra as curvas de separabilidade com valores acumulados para os produtos afundados.

Tabela 5.1 - Distribuição de massa do agregado IT-C nos intervalos de densidade

\begin{tabular}{|c|c|c|c|c|c|c|c|c|c|}
\hline \multirow{2}{*}{$\begin{array}{c}\text { Fração } \\
\text { (mm) }\end{array}$} & \multicolumn{5}{|c|}{$\%$ Massa } & \multicolumn{4}{|c|}{ Valores acumulados para o afundado } \\
\hline & $d<1,7$ & $1,7<d<1,9$ & $1,9<d<22$ & $2,2<d<2,5$ & $d>2,5$ & $d>1,7$ & $d>1,9$ & $d>2,2$ & $d>2,5$ \\
\hline$-25,4+19,1$ & 0,57 & 1,88 & 32,5 & 36,2 & 28,9 & 99,4 & 97,5 & 65,1 & 28,9 \\
\hline$-19,1+12,7$ & 0,40 & 3,97 & 34,1 & 33,2 & 28,4 & 99,6 & 95,6 & 61,6 & 28,4 \\
\hline$-12,7+9,5$ & 0,16 & 1,07 & 11,1 & 53,1 & 34,6 & 99,8 & 98,8 & 87,7 & 34,6 \\
\hline$-9,5+4,8$ & 0,27 & 1,07 & 13,5 & 50,9 & 34,3 & 99,7 & 98,7 & 85,1 & 34,3 \\
\hline$-4,8+1,2$ & 0,43 & 1,16 & 12,8 & 59,0 & 26,6 & 99,6 & 98,4 & 85,6 & 26,6 \\
\hline$-1,2+0,3$ & 0,23 & 1,05 & 2,35 & 31,6 & 64,8 & 99,8 & 98,7 & 96,4 & 64,8 \\
\hline
\end{tabular}

Nota-se um comportamento bastante diferenciado entre as frações graúda, intermediária e miúda; esta última é a que possui menor quantidade em massa de material com $\mathrm{d}<1,9 \mathrm{~g} / \mathrm{cm}^{3}$ e maior fração de areia e fragmentos de rocha liberados $\left(\mathrm{d}>2,5 \mathrm{~g} / \mathrm{cm}^{3}\right)$.

A curva de separabilidade indica ainda que a liberação dos minerais é pouco eficiente nas duas frações mais grossas (baixa inclinação da curva de separabilidade), e que esta aumenta no sentido das frações mais finas. 


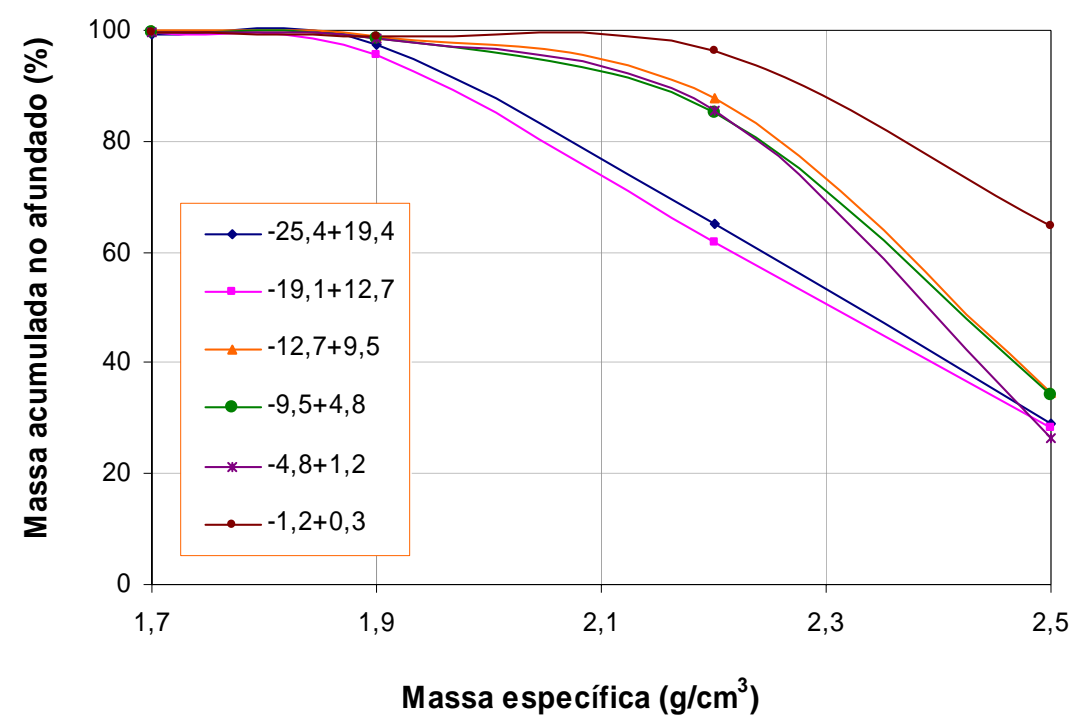

Figura 5.1 - Curvas de separabilidade por densidade de IT-C com valores em massa acumulados para o afundado

\subsubsection{Itaquera vermelho}

A Tabela 5.2 apresenta a distribuição em massa por fração granulométrica para cada intervalo de densidade dos agregados IT-V e a Figura 5.2 as curvas de separabilidade com valores acumulados para os produtos afundados.

Tabela 5.2 - Distribuição de massa do agregado IT-V nos intervalos de densidade

\begin{tabular}{|c|c|c|c|c|c|c|c|c|c|}
\hline \multirow{2}{*}{$\begin{array}{c}\text { Fração } \\
(\mathrm{mm})\end{array}$} & \multicolumn{5}{|c|}{$\%$ Massa } & \multicolumn{4}{|c|}{ Valores acumulados para o afundado (\%) } \\
\hline & $d<1,7$ & $1,7<d<1,9$ & $1,9<d<22$ & $2,2<d<2,5$ & $d>2,5$ & $d>1,7$ & $d>1,9$ & $d>2,2$ & $d>2,5$ \\
\hline$-25,4+19,1$ & 0,56 & 3,83 & 41,3 & 26,7 & 27,6 & 99,4 & 95,6 & 54,3 & 27,6 \\
\hline$-19,1+12,7$ & 0,96 & 2,83 & 40,7 & 26,5 & 29,0 & 99,0 & 96,2 & 55,5 & 29,0 \\
\hline$-12,7+9,5$ & 0,44 & 0,35 & 21,6 & 43,5 & 34,2 & 99,6 & 99,2 & 77,6 & 34,2 \\
\hline$-9,5+4,8$ & 0,93 & 0,18 & 11,8 & 55,4 & 31,8 & 99,1 & 98,9 & 87,1 & 31,8 \\
\hline$-4,8+1,2$ & 1,29 & 2,85 & 3,95 & 73,8 & 18,2 & 98,7 & 95,9 & 91,9 & 18,2 \\
\hline$-1,2+0,3$ & 1,47 & 0,22 & 3,22 & 18,7 & 76,3 & 98,5 & 98,3 & 95,1 & 76,3 \\
\hline
\end{tabular}




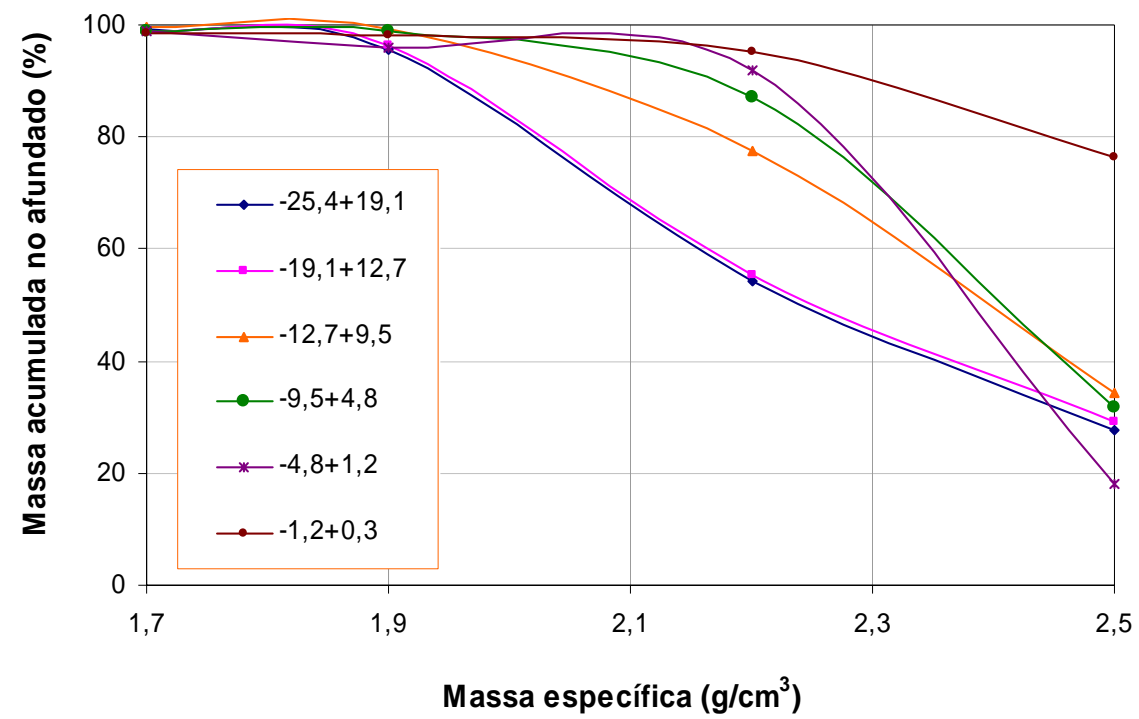

Figura 5.2 - Curvas de separabilidade por densidade de IT-V com valores em massa acumulados para o afundado

Analogamente a IT-C, verifica-se um comportamento diferenciado em função da granulometria do material, sendo que a fração miúda apresenta maior proporção de material com $\mathrm{d}>2,5 \mathrm{~g} / \mathrm{cm}^{3}$ (areia e de fragmentos de rochas liberados).

A fração $-4,8+1,2 \mathrm{~mm}$ é a que, comparativamente, tem um comportamento mais irregular, com elevada quantidade de material entre as densidades 2,2 e $2,5 \mathrm{~g} / \mathrm{cm}^{3}$ e somente $18 \%$ com densidade superior a $2,5 \mathrm{~g} / \mathrm{cm}^{3}$.

\subsubsection{Vinhedo vermelho}

A Tabela 5.3 apresenta a distribuição em massa por fração granulométrica para cada intervalo de densidade dos agregados VI-V e a Figura 5.3 as curvas de separabilidade com valores acumulados para os produtos afundados. 
Tabela 5.3 - Distribuição de massa do agregado VI-V nos intervalos de densidade

\begin{tabular}{|c|c|c|c|c|c|c|c|}
\hline \multirow{2}{*}{$\begin{array}{c}\text { Fração } \\
(\mathbf{m m})\end{array}$} & \multicolumn{4}{|c|}{ \% Massa $^{15}$} & \multicolumn{3}{c|}{ Valores acumulados para o afundado } \\
\cline { 2 - 8 } & $d<1,9$ & $1,9<d<22$ & $2,2<d<2,5$ & $d>2,5$ & $d>1,9$ & $d>2,2$ & $d>2,5$ \\
\hline$-25,4+19,1$ & 19,6 & 42,2 & 23,6 & 14,6 & 80,4 & 38,2 & 14,6 \\
\hline$-19,1+12,7$ & 16,7 & 44,5 & 22,9 & 15,9 & 83,3 & 38,8 & 15,9 \\
\hline$-12,7+9,5$ & 10,3 & 24,4 & 58,2 & 7,0 & 89,7 & 65,2 & 7,0 \\
\hline$-9,5+4,8$ & 2,62 & 57,8 & 16,4 & 23,2 & 97,4 & 39,6 & 23,2 \\
\hline$-4,8+2,4$ & 0,97 & 27,4 & 41,7 & 29,9 & 99,0 & 71,6 & 29,9 \\
\hline$-2,4+1,2$ & 0,49 & 3,10 & 48,1 & 48,3 & 99,5 & 96,4 & 48,3 \\
\hline$-1,2+0,3$ & 0,23 & 1,35 & 35,7 & 62,7 & 99,8 & 98,4 & 62,7 \\
\hline
\end{tabular}

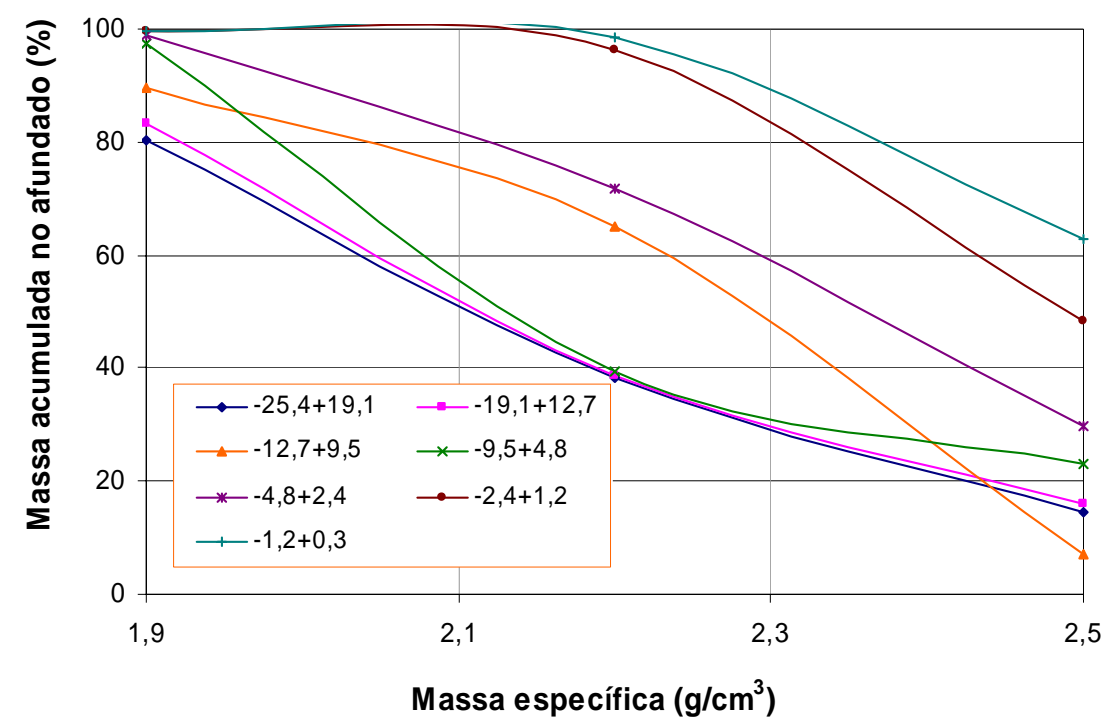

Figura 5.3 - Curvas de separabilidade por densidade de VI-V com valores em massa acumulados para $o$ afundado

As curvas de separabilidade de VI-V apresentam um comportamento semelhante às anteriores, porém com valores distintos. A proporção de material de densidade menor que $1,9 \mathrm{~g} / \mathrm{cm}^{3}$ nos produtos graúdos corresponde a cerca de $20 \%$ do total (elevado teor de material cerâmico de alta porosidade), enquanto que nos agregados reciclados de Itaquera esse valor é inferior a 5\%. Já para os agregados miúdos a proporção

${ }^{15}$ A proporção de material de $\mathrm{d}<1,7$ de VI-V foi inferior a $0,3 \%$ (em massa) e, portanto, foi considerada parte do produto $\mathrm{d}<1,9 \mathrm{~g} / \mathrm{cm}^{3}$. 
material com densidade superior a $2,5 \mathrm{~g} / \mathrm{cm}^{3}$ (areia e fragmentos de rochas liberados) se mantém semelhante aos agregados de Itaquera.

\subsubsection{Sumário dos resultados}

Os três diferentes agregados apresentam comportamentos semelhantes na densidade para cada intervalo granulométrico, sendo que o VI-V tem maior quantidade de material leve $\left(<1,9 \mathrm{~g} / \mathrm{cm}^{3}\right)$ na fração graúda, chegando até a $20 \%$, contra os $5 \%$ dos agregados de Itaquera.

A liberação da fração mineral, indicada pela proporção em massa de material nos produtos afundados, é maior nas frações mais finas; nesse sentido IT-C e IT-V são muito semelhantes, enquanto VI-V apresenta um produto graúdo bastante diferente.

Observa-se um comportamento diferenciado para as frações graúda e miúda, conforme apresentado na Figura 5.4 e discutido a seguir.
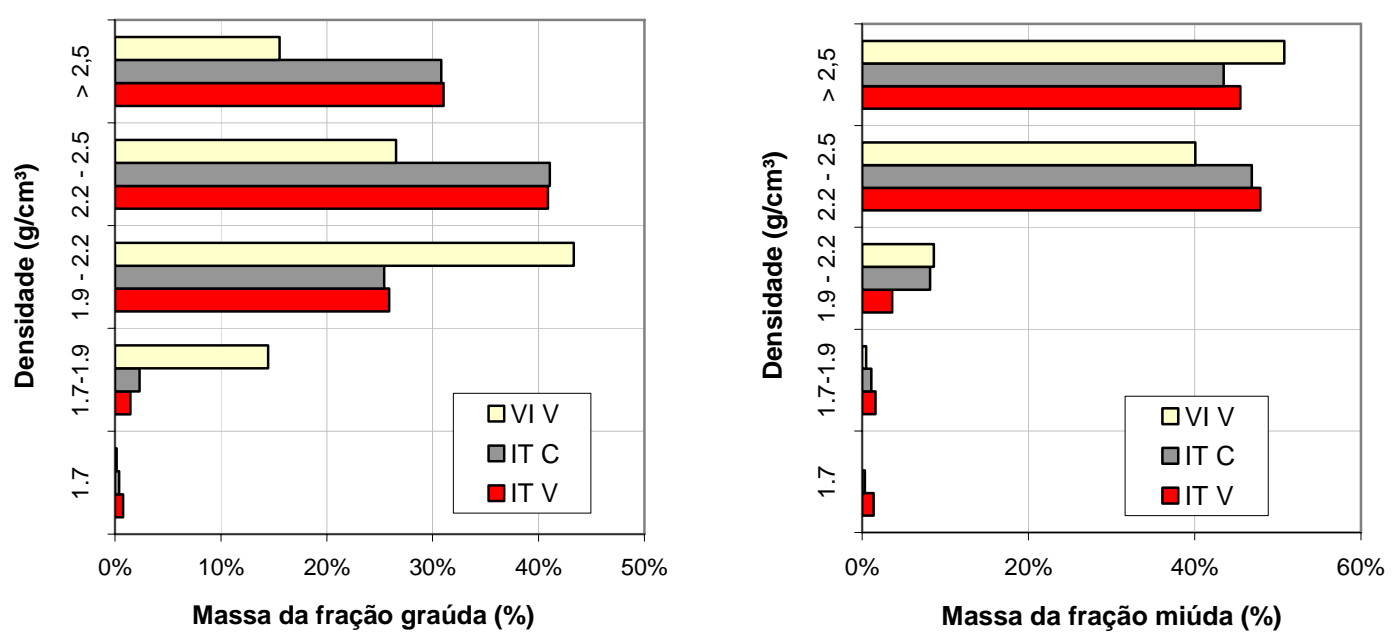

Figura 5.4 - Distribuição dos produtos nas densidades

Produtos graúdos de RCD vermelho apresentam distribuição em massa distinta para as duas instalações de reciclagem, sendo que o produto de Itaquera é de melhor qualidade em relação ao produto de Vinhedo quanto à distribuição de massa nos produtos mais densos. Os produtos cinza e vermelho apresentaram a mesma distribuição de massa, não sendo, portanto, a cor, um critério seletivo; novamente, a classificação baseada no critério visual não pode ser empregada para a avaliação da qualidade dos produtos segundo estes parâmetros físicos. 
Uma separação por densidade pode ser empregada com o objetivo de se obter agregados graúdos de melhor qualidade uma vez que mais da metade da massa destes agregados possui densidade superior a $2,2 \mathrm{~g} / \mathrm{cm}^{3}$ e podem ser superiores também quanto aos critérios físicos.

Os produtos miúdos da separação apresentam distribuição semelhante não importando sua origem ou classificação (cinza ou vermelho). Mais de $80 \%$ da massa destes produtos se encontram nos intervalos de densidade acima de $2,2 \mathrm{~g} / \mathrm{cm}^{3}$, o que permite inferir, num primeiro momento, que a qualidade dos agregados miúdos pode ser superior a dos agregados graúdos quanto aos critérios físicos de massa específica aparente e absorção de água. Entretanto, ensaios de caracterização da fração miúda são necessários para confirmar tal hipótese.

\subsection{COMPOSIÇÃO QUÍMICA POR FAIXA DENSITÁRIA}

Os resultados de análises químicas dos principais óxidos relativos aos produtos da separação por líquidos densos são apresentados por faixa densitária a seguir; análises químicas mais detalhadas são apresentadas no Apêndice.

\subsubsection{Itaquera cinza}

A Tabela 5.4 apresenta os teores dos principais óxidos relativos aos produtos de separações por densidade do agregado reciclado IT-C; os teores de $\mathrm{SiO}_{2}, \mathrm{CaO}, \mathrm{SiO}_{2}$ e P.F são também apresentados comparativamente na Figura 5.5. 
Tabela 5.4 - Análise química dos produtos de separação por líquidos densos: IT-C

\begin{tabular}{|c|c|c|c|c|c|c|c|c|c|c|c|c|c|c|c|c|}
\hline \multirow{2}{*}{$\begin{array}{c}\text { Produto/ } \\
\text { Fração (mm) }\end{array}$} & \multicolumn{2}{|c|}{$\%$ Massa } & \multicolumn{6}{|c|}{ Teores (\%) } & \multicolumn{4}{|c|}{ Distribuição ensaio (\%) } & \multicolumn{4}{|c|}{ Distribuição amostra (\%) } \\
\hline & Ensaio & Am. & $\mathrm{iO}_{2}$ & $\mathrm{Al}_{2} \mathrm{O}_{3}$ & $\mathrm{Fe}_{2} \mathrm{O}_{3}$ & $\mathrm{CaO}$ & $\mathrm{MgO}$ & PF & $\mathrm{SiO}_{2}$ & $\mathrm{Al}_{2} \mathrm{O}_{3}$ & $\mathrm{Fe}_{2} \mathrm{O}_{3}$ & $\mathrm{CaO}$ & $\mathrm{SiO}_{2}$ & $\mathrm{Al}_{2} \mathrm{O}_{3}$ & $\mathrm{Fe}_{2} \mathrm{O}_{3}$ & $\mathrm{CaO}$ \\
\hline \multicolumn{17}{|l|}{$-25,4+19,1$} \\
\hline & 0,6 & 0,1 & $\ldots$ & $\ldots$ & $\ldots$ & $\ldots$ & $\ldots$ & $\ldots$ & $\ldots$ & $\ldots$ & $\ldots$ & $\ldots$ & $\ldots$ & $\ldots$ & $\ldots$ & $\ldots$ \\
\hline $1,7<d<1,9$ & 1,9 & 0,3 & 60,2 & 8,45 & 3,37 & 7,61 & 1,44 & 15,9 & 1,8 & 1,6 & 1,9 & 1,8 & 0,3 & 0,3 & 0,3 & 0,3 \\
\hline $1,9<d<2,2$ & 2,5 & 5,1 & 5,1 & 6,86 & 2,05 & 9,90 & 1,18 & 10,9 & 33,4 & 22,1 & 20,1 & 40,5 & 5,2 & 3,8 & 3,6 & 6,7 \\
\hline & 6,2 & 5,7 & 3,9 & 10,2 & 2,81 & 8,36 & 1,51 & 7,92 & & 36,7 & 30,7 & 38,1 & 5,7 & 3 & & 6,3 \\
\hline & 8,9 & 4,6 & 2,3 & 13,8 & 5,43 & 5,37 & 1,64 & 3,48 & 28,4 & 39,6 & & 19,6 & 4,4 & 6,8 & 3,4 & 3,2 \\
\hline rotua & 100,0 & 15,8 & 63,4 & 10,1 & 3,31 & 7,93 & 1,43 & 7,71 & 100,0 & 100,0 & 100,0 & 100,0 & 15,5 & 17,1 & 17,8 & 16,6 \\
\hline \multicolumn{17}{|l|}{$-19,1+12,7$} \\
\hline & 0,4 & 0,1 & $\ldots$ & $\ldots$ & $\ldots$ & $\ldots$ & & $\ldots$ & $\ldots$ & $\ldots$ & $\ldots$ & $\ldots$ & $\ldots$ & $\ldots$ & $\ldots$ & $\ldots$ \\
\hline 1,7 & 4,0 & 0,9 & 44,4 & 5,30 & 2,14 & 18,3 & 2,63 & 232 & 3,1 & 1,8 & 2,2 & 10,3 & 0,7 & & & 2,4 \\
\hline 1,9 & 34,1 & 7,4 & 34.5 & 5.82 & 1.79 & 10.9 & 1.53 & 12.0 & 34.5 & 22.4 & 20.2 & 43.1 & 7.4 & 5.1 & 5.1 & 9.9 \\
\hline & 3,2 & 7,2 & 67,8 & 8,75 & 3, & 7,29 & 1,03 & 7,22 & & 24,2 & 26,8 & 34,3 & 8,4 & & 7 & 7,9 \\
\hline & 28,4 & 6,2 & 61,5 & 13,2 & 4,57 & 6,16 & 1,47 & 4,49 & 30,5 & 31,3 & 34,2 & 24,8 & 6,6 & 7,1 & 8,6 & 5,7 \\
\hline & 100,0 & 21,8 & 57,3 & 12,0 & 3,80 & 7,06 & 1,42 & 13,0 & 100,0 & 10 & 100,0 & 100,0 & 21,5 & & & 23,0 \\
\hline \multicolumn{17}{|l|}{$-12,7+9,5$} \\
\hline & 0,2 & & & $\ldots$ & $\ldots$ & $\ldots$ & $\ldots$ & $\ldots$ & & $\ldots$ & $\ldots$ & $\ldots$ & $\ldots$ & $\ldots$ & $\ldots$ & $\ldots$ \\
\hline 1,7 & & 0,1 & 45,8 & 15,0 & 4,10 & 6,35 & 1,63 & 247 & & & & 0,9 & & & & 0,1 \\
\hline 1,9 & & & 8,0 & 7,72 & 2 , & & 1,84 & & & 8,8 & 9,6 & 6,3 & , & & & 1,5 \\
\hline & & 4, & 5,5 & 7,76 & 2 & 8,66 & 1,26 & & 54,3 & 42,3 & 42,8 & 0,8 & & & & 5,4 \\
\hline & 4,6 & 3,2 & 4,5 & 13,3 & & 4,81 & 1,16 & 3,38 & & 47,2 & 46,2 & 22,0 & & & & 2,0 \\
\hline & 100,0 & 9,2 & 4,0 & 9,74 & & 7,56 & 1,29 & 8,21 & 100,0 & 100,0 & 100,0 & 100,0 & 9,4 & & & 8,9 \\
\hline$-9,5+4,8$ & & & & & & & & & & & & & & & & \\
\hline & & & & $\ldots$ & $\ldots$ & $\ldots$ & $\ldots$ & $\ldots$ & & & $\ldots$ & $\ldots$ & & & & $\ldots$ \\
\hline & & & & & & & & & & & & & & & & 0,2 \\
\hline 1,9 & & 1,9 & 0,8 & 6,87 & 2,18 & & 1,15 & & & 10,1 & & 19,0 & & & & 2,6 \\
\hline 2,2 & 5 & 7 & 6,6 & 7,28 & 1,78 & 9,04 & 1,04 & & & 40 & 35 & 6 & 4 & & & 7,7 \\
\hline & & & 2,4 & 13,0 & 3,86 & & 1,52 & & & & & & & & & 3,3 \\
\hline & 100,0 & 14,0 & 3,8 & 9,16 & 2,55 & 8,27 & 1,22 & 9,22 & 100,0 & 100,0 & & 100,0 & 13,9 & & & 13,9 \\
\hline & & & & & & & & & & & & & & & & \\
\hline & & & & & & & & & & & & & & & & $\ldots$ \\
\hline & & & & & & & & & & & & & & & & \\
\hline & 1 & & 7,2 & 8,68 & 2,32 & 10,7 & 1,21 & & & 13,8 & 12,2 & 20,6 & & & & 3,4 \\
\hline & & & & & & & & & & & & & & & & 10,4 \\
\hline & & & & 10,4 & & 3,41 & 0,98 & & & & & & & & & 2,2 \\
\hline & 100,0 & 16,8 & 67,8 & 8,08 & 2,44 & 6,66 & 0,95 & 8,68 & 100,0 & 100,0 & 100,0 & 100,0 & 16,9 & 16,5 & & 16,3 \\
\hline & & & & & & & & & & & & & & & & \\
\hline & & & & & & & & & & & & & & & & $\ldots$ \\
\hline & & & & & & & & & & & & & & & & 0,1 \\
\hline & & & & & 4,75 & 8,56 & 1,64 & & & 6,7 & & & & & & 0,5 \\
\hline & & & & & & & & & & & & & & & & 6,1 \\
\hline & & & 6,0 & 3,88 & 2,34 & 2,00 & & & & & & & & & & 3,4 \\
\hline & & 13,3 & 77,2 & 5,82 & 2,45 & 3,88 & 0,65 & & 100,0 & & & & 14,7 & & & 10,2 \\
\hline & & & & & & & & & & & & & & & & \\
\hline & & & & & & & & & & & & & & & & $\ldots$ \\
\hline & & & & & & & & & & & & & & & & 3,0 \\
\hline & & & 2,6 & 6,87 & & & & & & & & & & & & \\
\hline & & 39,1 & & & & & 1,09 & & & & & & & & & 42,5 \\
\hline & & & & & & & & & & & & & & & & \\
\hline & & 90,9 & 6,4 & 8,61 & 2,82 & 7,28 & 1,17 & 8,18 & 100,0 & 100,0 & 100,0 & 100,0 & 92,0 & & & 88,9 \\
\hline & & & & & & & & & & & & & & & & \\
\hline & & & & & & & & & & $\cdots$ & $\cdots$ & $\cdots$ & $\cdots$ & & $\cdots$ & $\ldots$ \\
\hline & & & & & & & & & & & & & & & & 2,5 \\
\hline & & & & 6,42 & 1,99 & 10,67 & 1,39 & & & 17,4 & & & & & & 20,7 \\
\hline & & & & & & & & & & & & & & & & 25,9 \\
\hline & & & & & & & & & & & 46,5 & & & & & 13,2 \\
\hline & 100,0 & 60,9 & 63,7 & 9,4 & 3,00 & 8,19 & 1,34 & 8,48 & 100,0 & 100,0 & 100,0 & 100,0 & 60,4 & 64,0 & 65,1 & 62,4 \\
\hline & & & & & & & & & & & & & & & & \\
\hline & & & & & & & & & & & & & & & & \\
\hline & & & & & & & & & & & & & & & & 0,5 \\
\hline & & & 54,8 & 9,68 & 2,63 & 10,4 & 1,26 & 16,4 & 6,2 & 11,2 & 8,8 & 15,7 & 2,0 & 2,9 & 2,3 & 3,9 \\
\hline & & & & 7,50 & 1,98 & 7,25 & 0,92 & & & 49,6 & 38,0 & 62,6 & & & 9,7 & 16,5 \\
\hline & & & & & 2,84 & & & & 49,3 & 37,5 & 50,5 & 19,9 & 15,5 & 10,0 & 12,4 & 5,6 \\
\hline Total & 100,0 & 30,1 & 71,9 & 7,08 & 2,45 & 5,42 & 0,82 & 7,59 & 100,0 & 100,0 & 100,0 & 100,0 & 31,6 & 26,6 & 25,1 & 26,5 \\
\hline
\end{tabular}


Os teores de sílica tendem a aumentar para os produtos de maior densidade, com teor de $45,8 \%$ para os produtos de densidade menor que 1,9 e acima de $60 \%$ para os produtos de densidade superior a $1,9 \mathrm{~g} / \mathrm{cm}^{3}$; comportamento inverso é observado para o óxido de cálcio, com variações de 13,3 a 4,3\% e o $\mathrm{MgO}$, com teores de 2,1 abaixo de $1,9 \mathrm{~g} / \mathrm{cm}^{3}$ e cerca entre 1,1 e $1,4 \%$ para os produtos de maior densidade. $\mathrm{O}$ teor de alumina aumenta para os mais densos e é, em média, 8,61\%; o óxido de ferro apresenta enriquecimento para as frações extremas, com teor médio de $2,8 \%$. A perda ao fogo, no entanto, é sistematicamente maior para os menos densos (de 23,4 a $3,7 \%$, em média).
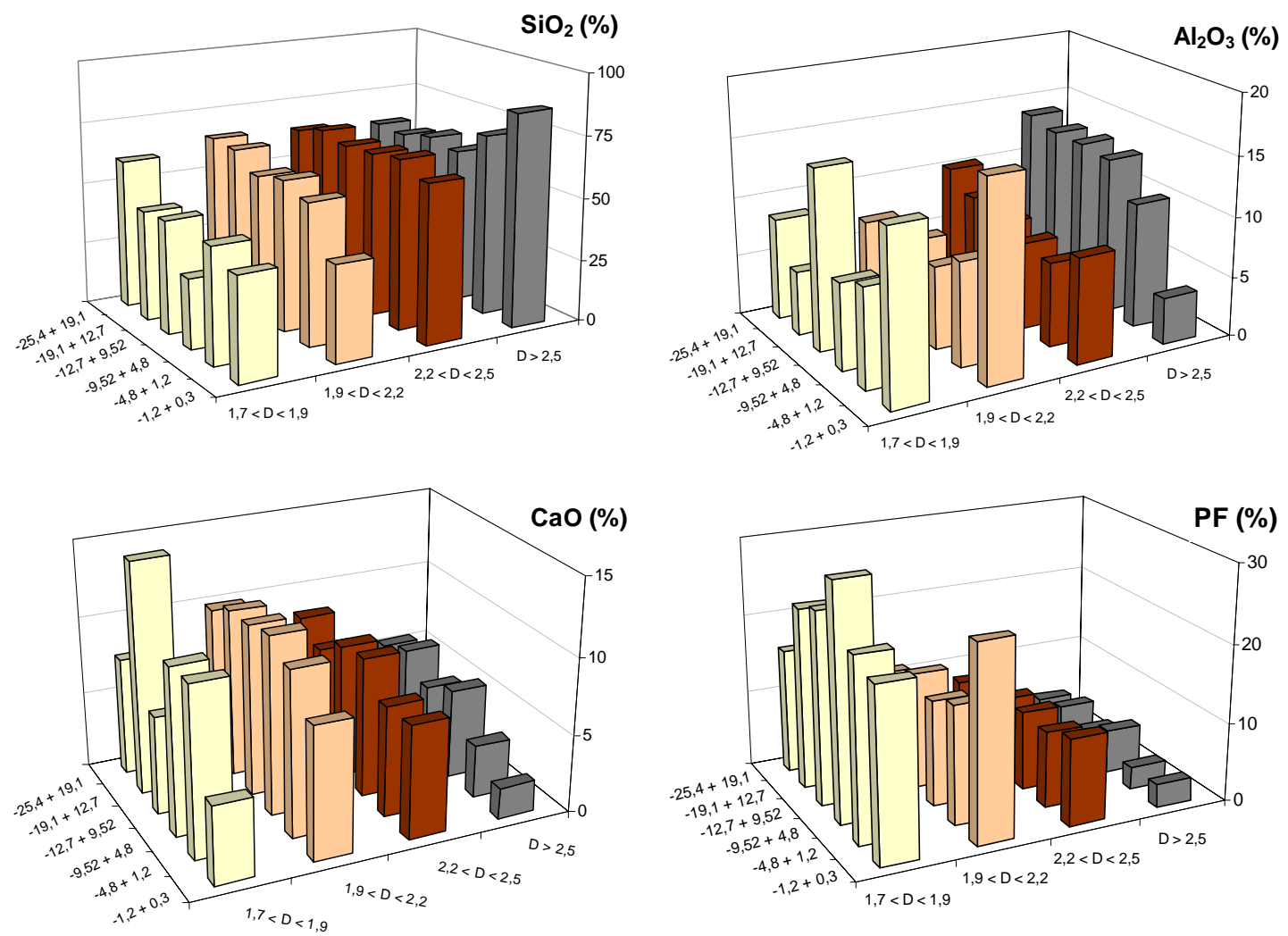

Figura 5.5 - Comparação entre teores dos principais óxidos para os produtos de separação em líquidos densos: IT-C

\subsubsection{Itaquera vermelho}

A Tabela 5.5 mostra os teores e a distribuição dos principais óxidos relativos aos produtos de separação em líquidos densos do agregado reciclado IT-V; os teores de $\mathrm{SiO}_{2}, \mathrm{CaO}, \mathrm{SiO}_{2}$ e P.F são também apresentados comparativamente na Figura 5.6. 
Tabela 5.5 - Análise química dos produtos de separação por líquidos densos: IT-V

\begin{tabular}{|c|c|c|c|c|c|c|c|c|c|c|c|c|c|c|c|c|}
\hline \multirow{2}{*}{$\begin{array}{c}\text { Produto/ } \\
\text { Fração }(\mathrm{mm})\end{array}$} & \multicolumn{2}{|c|}{$\%$ Massa } & \multicolumn{6}{|c|}{ Teores (\%) } & \multicolumn{4}{|c|}{ Distribuição ensaio (\%) } & \multicolumn{4}{|c|}{ Distribuição amostra (\%) } \\
\hline & Ensaio & Am. & $\mathrm{SiO}_{2}$ & $\mathrm{Al}_{2} \mathrm{O}_{3}$ & $\mathrm{Fe}_{2} \mathrm{O}_{3}$ & $\mathrm{CaO}$ & $\mathrm{MgO}$ & PF & $\mathrm{SiO}_{2}$ & $\mathrm{Al}_{2} \mathrm{O}_{3}$ & $\mathrm{Fe}_{2} \mathrm{O}_{3}$ & $\mathrm{CaO}$ & $\mathrm{SiO}_{2}$ & $\mathrm{Al}_{2} \mathrm{O}_{3}$ & $\mathrm{Fe}_{2} \mathrm{O}_{3}$ & $\mathrm{CaO}$ \\
\hline$-25,4+19,1$ & & & & & & & & & & & & & & & & \\
\hline$d<1,7$ & 0,6 & 0,2 & $\ldots$ & $\ldots$ & $\ldots$ & $\ldots$ & $\ldots$ & $\ldots$ & $\ldots$ & $\ldots$ & $\ldots$ & $\ldots$ & $\ldots$ & $\ldots$ & $\ldots$ & $\ldots$ \\
\hline $1,7<d<1,9$ & 3,8 & 1,2 & 46,2 & 10,3 & 2,50 & 7,54 & 1,37 & 27,7 & 2,78 & 3,94 & 3,10 & 4,14 & 0,2 & 0,3 & 0,2 & 0,2 \\
\hline $1,9<d<2,2$ & 41,3 & 13,3 & 62,7 & 9,45 & 3,28 & 7,21 & 1,14 & 10,4 & 40,7 & 39,0 & 43,8 & 42,7 & 2,8 & 3,2 & 3,1 & 2,4 \\
\hline $2,2<d<2,5$ & 26,7 & 8,6 & 64,8 & 13,0 & 3,46 & 3,59 & 0,95 & 6,75 & 27,2 & 34,7 & 29,9 & 13,8 & 1,9 & 2,8 & 2,1 & 0,8 \\
\hline$d>2,5$ & 27,6 & 8,9 & 67,6 & 8,10 & 2,60 & 9,96 & 1,84 & 5,42 & 29,3 & 22,3 & 23,2 & 39,4 & 2,1 & 1,8 & 1,7 & 2,2 \\
\hline Total & 100,0 & 32,3 & 63,6 & 10,0 & 3,09 & 6,97 & 1,28 & 8,65 & 100,0 & 100,0 & 100,0 & 100,0 & 7,0 & 8,2 & 7,1 & 5,7 \\
\hline$-19,1+12,7$ & & & & & & & & & & & & & & & & \\
\hline$d<1,7$ & 1,0 & 0,4 & $\ldots$ & $\ldots$ & $\ldots$ & $\ldots$ & $\ldots$ & $\ldots$ & $\ldots$ & $\ldots$ & $\ldots$ & $\ldots$ & $\ldots$ & $\ldots$ & $\ldots$ & $\ldots$ \\
\hline $1,7<d<1,9$ & 2,8 & 1,1 & 40,7 & 9,84 & 3,35 & 11,1 & 2,24 & 29,5 & 1,79 & 3,27 & 3,51 & 3,74 & 0,2 & 0,4 & 0,5 & 0,5 \\
\hline $1,9<d<2,2$ & 40,7 & 16,0 & 65,5 & 8,23 & 2,70 & 7,23 & 0,95 & 11,8 & 41,4 & 39,3 & 40,7 & 35,0 & 5,3 & 5,4 & 5,3 & 4,5 \\
\hline $2,2<d<2,5$ & 26,5 & 10,4 & 63,2 & 12,1 & 3,45 & 5,19 & 1,00 & 8,18 & 26,0 & 37,7 & 33,9 & 16,4 & 3,3 & 5,1 & 4,4 & 2,1 \\
\hline$d>2,5$ & 29,0 & 11,4 & 68,5 & 5,81 & 2,04 & 13,0 & 2,15 & 3,78 & 30,8 & 19,8 & 21,9 & 44,8 & 4,0 & 2,7 & 2,8 & 5,8 \\
\hline Total & 100,0 & 39,2 & 64,4 & 8,52 & 2,70 & 8,40 & 1,34 & 8,90 & 100,0 & 100,0 & 100,0 & 100,0 & 12,8 & 13,7 & 13,0 & 12,9 \\
\hline$-12,7+9,5$ & & & & & & & & & & & & & & & & \\
\hline$d<1,7$ & 0,4 & 0,0 & $\ldots$ & $\ldots$ & $\ldots$ & $\ldots$ & $\ldots$ & $\ldots$ & $\ldots$ & $\ldots$ & $\ldots$ & $\ldots$ & $\ldots$ & $\ldots$ & $\ldots$ & $\ldots$ \\
\hline $1,7<d<1,9$ & 0,3 & 0,0 & 51,4 & 15,1 & 4,18 & 4,06 & 1,26 & 20,8 & 0,28 & 0,49 & 0,40 & 0,17 & 0,0 & 0,1 & 0,0 & 0,0 \\
\hline $1,9<d<2,2$ & 21,6 & 1,7 & 64,3 & 7,28 & 2,31 & 8,26 & 1,01 & 12,5 & 21,9 & 14,9 & 13,9 & 21,4 & 2,5 & 1,9 & 1,7 & 3,5 \\
\hline $2,2<d<2,5$ & 43,5 & 3,4 & 64,3 & 12,0 & 4,30 & 4,84 & 0,90 & 7,13 & 44,2 & 49,4 & 52,2 & 25,2 & 5,1 & 6,2 & 6,4 & 4,1 \\
\hline$d>2,5$ & 34,2 & 2,7 & 62,3 & 10,9 & 3,51 & 13,0 & 2,17 & 4,94 & 33,6 & 35,2 & 33,5 & 53,2 & 3,8 & 4,5 & 4,1 & 8,6 \\
\hline Total & 100,0 & 7,9 & 63,3 & 10,6 & 3,58 & 8,34 & 1,35 & 7,56 & 100,0 & 100,0 & 100,0 & 100,0 & 11,4 & 12,6 & 12,3 & 16,2 \\
\hline$-9,5+4,8$ & & & & & & & & & & & & & & & & \\
\hline$d<1,7$ & 0,9 & 0,1 & & $\ldots$ & $\ldots$ & $\ldots$ & $\ldots$ & $\ldots$ & $\ldots$ & $\ldots$ & $\ldots$ & $\ldots$ & $\ldots$ & $\ldots$ & $\ldots$ & $\ldots$ \\
\hline $1,7<d<1,9$ & 0,2 & 0,0 & 48,2 & 10,7 & 2,77 & 7,59 & 1,42 & 24,9 & 0,13 & 0,15 & 0,12 & 0,35 & 0,0 & 0,0 & 0,0 & 0,1 \\
\hline $1,9<d<2,2$ & 11,7 & 0,8 & 67,3 & 8,04 & 2,09 & 3,64 & 0,73 & 13,6 & 12,3 & 7,37 & 5,84 & 11,1 & 2,0 & 1,2 & 1,0 & 1,9 \\
\hline $2,2<d<2,5$ & 55,4 & 3,8 & 69,7 & 8,44 & 4,10 & 3,55 & 1,23 & 9,09 & 60,0 & 36,5 & 54,1 & 51,0 & 10,0 & 6,1 & 9,4 & 8,8 \\
\hline$d>2,5$ & 31,8 & 2,1 & 55,9 & 22,6 & 5,29 & 4,57 & 1,23 & 4,63 & 27,6 & 56,0 & 40,0 & 37,6 & 4,6 & 9,4 & 7,0 & 6,5 \\
\hline Total & 100,0 & 6,8 & 64,3 & 12,8 & 4,20 & 3,86 & 1,16 & 8,15 & 100,0 & 100,0 & 100,0 & 100,0 & 16,7 & 16,8 & 17,5 & 17,3 \\
\hline$-4,8+1,2$ & & & & & & & & & & & & & & & & \\
\hline$d<1,7$ & 1,3 & 0,1 & $\ldots$ & $\ldots$ & $\ldots$ & $\ldots$ & $\ldots$ & $\ldots$ & $\ldots$ & $\ldots$ & $\ldots$ & $\ldots$ & $\ldots$ & $\ldots$ & $\ldots$ & $\ldots$ \\
\hline $1,7<d<1,9$ & 2,9 & 0,2 & 49,6 & 10,2 & 4,18 & 5,45 & 1,20 & 23,8 & 1,93 & 4,60 & 3,39 & 5,80 & 0,4 & 0,9 & 0,7 & 1,2 \\
\hline $1,9<d<2,2$ & 3,9 & 0,2 & 54,4 & 16,4 & 4,10 & 4,11 & 0,82 & 13,8 & 2,94 & 10,3 & 4,62 & 6,06 & 0,6 & 2,1 & 0,9 & 1,3 \\
\hline $2,2<d<2,5$ & 73,8 & 4,5 & 76,4 & 5,07 & 3,32 & 2,30 & 0,58 & 9,71 & 77,1 & 59,4 & 69,8 & 63,3 & 16,7 & 11,8 & 13,6 & 13,2 \\
\hline$d>2,5$ & 18,2 & 1,1 & 72,7 & 8,89 & 4,29 & 3,67 & 1,28 & 3,96 & 18,1 & 25,7 & 22,2 & 24,9 & 3,9 & 5,1 & 4,3 & 5,2 \\
\hline Total & 100,0 & 6,1 & 73,1 & 6,29 & 3,51 & 2,68 & 0,73 & 9,10 & 100,0 & 100,0 & 100,0 & 100,0 & 21,7 & 19,9 & 19,5 & 20,8 \\
\hline & & & & & & & & & & & & & & & & \\
\hline$d<1,7$ & 1,5 & 0,1 & $\ldots$ & $\ldots$ & $\ldots$ & $\ldots$ & $\ldots$ & $\ldots$ & $\ldots$ & $\ldots$ & $\ldots$ & $\ldots$ & $\ldots$ & $\ldots$ & $\ldots$ & $\ldots$ \\
\hline $1,7<d<1,9$ & 0,2 & 0,0 & 38,7 & 22,4 & 5,73 & 2,00 & 1,40 & 24,5 & 0,14 & 0,41 & 0,33 & 0,07 & 0,0 & 0,1 & 0,1 & 0,0 \\
\hline $1,9<d<2,2$ & 3,2 & 0,1 & 57,8 & 6,95 & 2,45 & 8,24 & 1,44 & 19,7 & 3,01 & 1,85 & 2,07 & 4,16 & 0,6 & 0,3 & 0,4 & 0,6 \\
\hline $2,2<d<2,5$ & 18,7 & 0,7 & 61,3 & 9,84 & 3,06 & 6,99 & 1,12 & 11,6 & 18,6 & 15,2 & 15,1 & 20,5 & 3,8 & 2,3 & 2,6 & 2,7 \\
\hline$d>2,5$ & 76,3 & 3,0 & 63,3 & 13,1 & 4,11 & 6,29 & 0,99 & 4,06 & 78,2 & 82,5 & 82,5 & 75,2 & 15,9 & 12,5 & 14,1 & 10,0 \\
\hline Total & 100,0 & 4,0 & 61,8 & 12,1 & 3,80 & 6,38 & 1,02 & 5,96 & 100,0 & 100,0 & 100,0 & 100,0 & 20,3 & 15,2 & 17,1 & 13,3 \\
\hline Total $+0,30$ & & & & & & & & & & & & & & & & \\
\hline & 1,0 & 0,9 & $\ldots$ & $\ldots$ & $\ldots$ & $\ldots$ & $\ldots$ & $\ldots$ & $\ldots$ & $\ldots$ & $\ldots$ & $\ldots$ & $\ldots$ & $\ldots$ & $\ldots$ & $\ldots$ \\
\hline $1,7<d<1,9$ & 1,5 & 1,3 & 46,3 & 10,6 & 3,65 & 7,25 & 1,52 & 26,0 & 1,07 & 1,62 & 1,55 & 1,96 & 0,9 & 1,8 & 1,5 & 2,0 \\
\hline $1,9<d<2,2$ & 15,7 & 13,9 & 64,0 & 8,72 & 2,73 & 6,75 & 0,98 & 12,4 & 15,3 & 13,8 & 12,0 & 19,0 & 14,0 & 14,0 & 12,4 & 14,1 \\
\hline $2,2<d<2,5$ & 44,1 & 39,0 & 70,2 & 8,19 & 3,63 & 3,67 & 0,88 & 9,13 & 47,1 & 36,3 & 44,9 & 28,9 & 40,8 & 34,5 & 38,6 & 31,7 \\
\hline$d>2,5$ & 37,6 & 33,3 & 63,9 & 12,81 & 3,94 & 7,45 & 1,38 & 4,29 & 36,6 & 48,4 & 41,5 & 50,1 & 34,3 & 36,0 & 34,1 & 38,3 \\
\hline Total & 100,0 & 88,5 & 65,7 & 9,96 & 3,57 & 5,59 & 1,08 & 7,98 & 100,0 & 100,0 & 100,0 & 100,0 & 90,0 & 86,4 & 86,5 & 86,1 \\
\hline$-25,4+4,8$ & & & & & & & & & & & & & & & & \\
\hline$d<1, f$ & 0,8 & 0,4 & & & & . & $\ldots$ & & & & & & $\ldots$ & . & $\cdots$ & $\ldots$ \\
\hline $1,9<d<1,9$ & 1,4 & 0,7 & 43,8 & 10,4 & 3,05 & 9,17 & 1,81 & 28,1 & 0,98 & 1,38 & 1,24 & 1,99 & 0,5 & 0,9 & 0,7 & 0,8 \\
\hline $1,9<d<2,2$ & 25,9 & 12,4 & 64,9 & 8,28 & 2,65 & 6,86 & 0,97 & 11,9 & 26,2 & 19,9 & 19,62 & 27,0 & 12,7 & 11,7 & 11,1 & 12,3 \\
\hline $2,2<d<2,5$ & 40,9 & 19,7 & 66,7 & 10,4 & 3,98 & 4,17 & 1,08 & 8,21 & 42,6 & 39,6 & 46,5 & 25,9 & 20,3 & 20,4 & 22,4 & 15,8 \\
\hline$d>2,5$ & 31,0 & 14,9 & 62,2 & 13,5 & 3,68 & 9,57 & 1,78 & 4,61 & 30,1 & 39,1 & 32,6 & 45,1 & 14,4 & 18,4 & 15,6 & 23,1 \\
\hline Total & 100,0 & 48,1 & 64,0 & 10,7 & 3,50 & 6,58 & 1,27 & $\ldots$ & 100,0 & 100,0 & 100,0 & 100,0 & 47,9 & 51,3 & 49,9 & 52,0 \\
\hline$-4,8+0,3$ & & & & & & & & & & & & & & & & \\
\hline$d<1,7$ & 1,4 & 0,6 & $\ldots$ & $\ldots$ & $\ldots$ & $\ldots$ & $\ldots$ & $\ldots$ & $\ldots$ & $\ldots$ & $\ldots$ & $\ldots$ & $\ldots$ & $\ldots$ & $\ldots$ & $\ldots$ \\
\hline $1,7<d<1,9$ & 1,6 & 0,7 & 48,9 & 10,9 & 4,28 & 5,23 & 1,22 & 23,8 & 1,17 & 1,96 & 1,90 & 1,92 & 0,4 & 1,0 & 0,7 & 1,2 \\
\hline $1,9<d<2,2$ & 3,6 & 1,5 & 55,8 & 12,4 & 3,41 & 5,84 & 1,08 & 16,3 & 2,97 & 4,97 & 3,37 & 4,77 & 1,3 & 2,3 & 1,3 & 1,8 \\
\hline $2,2<d<2,5$ & 47,9 & 19,4 & 73,6 & 5,94 & 3,27 & 3,16 & 0,68 & 10,1 & 52,1 & 31,6 & 43,0 & 34,3 & 20,5 & 14,1 & 16,2 & 15,9 \\
\hline$d>2,5$ & 45,5 & 18,4 & 65,3 & 12,2 & 4,15 & 5,73 & 1,05 & 4,04 & 43,8 & 61,5 & 51,7 & 59,0 & 19,8 & 17,6 & 18,5 & 15,2 \\
\hline Total & 100,0 & 40,4 & 67,8 & 9,03 & 3,65 & 4,42 & 0,86 & 7,63 & 100,0 & 100,0 & 100,0 & 100,0 & 42,0 & 35,1 & 36,6 & 34,1 \\
\hline
\end{tabular}


Analogamente a IT-C, os teores de $\mathrm{SiO}_{2}$ variam notoriamente entre os produtos de densidade menor e maior que $1,9 \mathrm{~g} / \mathrm{cm}^{3}$, desde $46,3 \%$ a teores superiores a $64 \%$; já o $\mathrm{CaO}$ apresenta teores próximos a 7\%, com marcante empobrecimento para o produto entre 2,2 e $2,5 \mathrm{~g} / \mathrm{cm}^{3}$ (3,7\%). Os teores de alumina, $\mathrm{Fe}_{2} \mathrm{O}_{3}$ e $\mathrm{MgO}$, são, em média, 10 , 3,6 e $1,1 \%$, respectivamente, com enriquecimento para os produtos extremos. A perda ao fogo decresce com o aumento da densidade, variando entre 26,0 e $4,3 \%$ (em média).
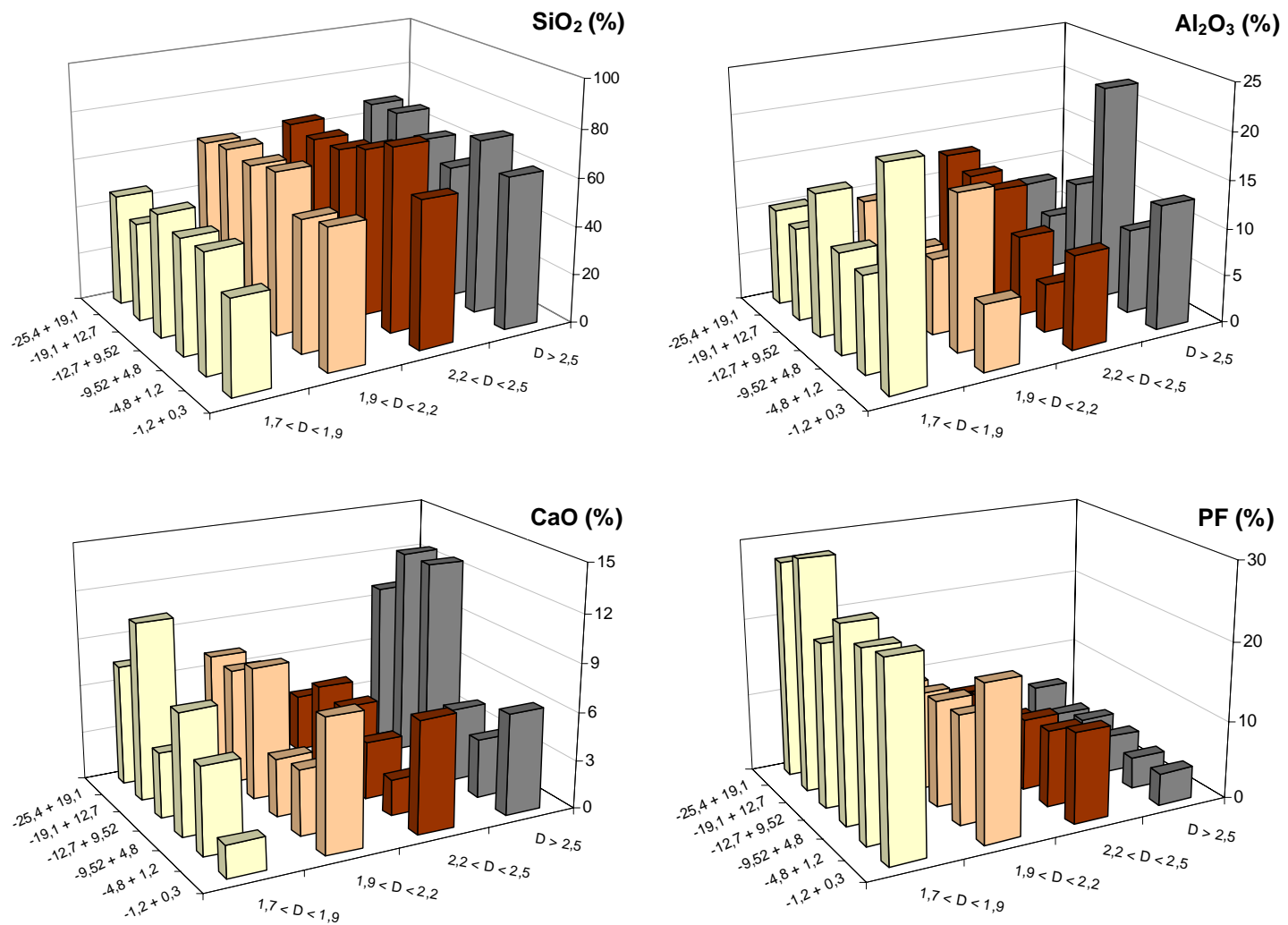

Figura 5.6 - Comparação entre teores dos principais óxidos para os produtos de separação em líquidos densos: IT-V

\subsubsection{Vinhedo vermelho}

A Tabela 5.6 apresenta os teores dos principais óxidos relativos aos produtos de separação densitária do agregado reciclado VI-V; os teores de $\mathrm{SiO}_{2}, \mathrm{CaO}, \mathrm{SiO}_{2}$ e P.F são também apresentados comparativamente na Figura 5.7. 
Tabela 5.6 - Análise química dos produtos de separação por líquidos densos: VI-V

\begin{tabular}{|c|c|c|c|c|c|c|c|c|c|c|c|c|c|c|c|c|}
\hline \multirow{2}{*}{$\begin{array}{c}\text { Produto/ } \\
\text { Fração (mm) }\end{array}$} & \multicolumn{2}{|c|}{$\%$ Massa } & \multicolumn{6}{|c|}{ Teores (\%) } & \multicolumn{4}{|c|}{ Distribuição ensaio (\%) } & \multicolumn{4}{|c|}{ Distribuição amostra (\%) } \\
\hline & Ensaio & Am. & $\mathrm{SiO}_{2}$ & $\mathrm{Al}_{2} \mathrm{O}_{3}$ & $\mathrm{Fe}_{2} \mathrm{O}_{3}$ & $\mathrm{CaO}$ & $\mathrm{MgO}$ & PF & $\mathrm{SiO}_{2}$ & $\mathrm{Al}_{2} \mathrm{O}_{3}$ & $\mathrm{Fe}_{2} \mathrm{O}_{3}$ & $\mathrm{CaO}$ & $\mathrm{SiO}_{2}$ & $\mathrm{Al}_{2} \mathrm{O}_{3}$ & $\mathrm{Fe}_{2} \mathrm{O}_{3}$ & $\mathrm{CaO}$ \\
\hline$-25,4+19,1$ & & & & & & & & & & & & & & & & \\
\hline$d<1,7$ & 19,6 & 3,1 & $\ldots$ & $\ldots$ & $\ldots$ & $\ldots$ & $\ldots$ & $\ldots$ & $\ldots$ & $\ldots$ & $\ldots$ & $\ldots$ & $\ldots$ & $\ldots$ & $\ldots$ & $\ldots$ \\
\hline $1,9<d<2,2$ & 42,2 & 6,7 & 66,3 & 7,01 & 2,46 & 7,57 & 1,15 & 12,4 & 50,5 & 43,1 & 49,1 & 72,3 & 7,7 & 7,0 & 7,0 & 17,6 \\
\hline $2,2<d<2,5$ & 23,6 & 3,8 & 71,6 & 8,78 & 2,46 & 4,53 & 0,77 & 7,13 & 30,5 & 30,2 & 27,5 & 24,2 & 4,6 & 4,9 & 3,9 & 5,9 \\
\hline$d>2,5$ & 14,6 & 2,3 & 72,1 & 12,5 & 3,38 & 1,04 & 0,84 & 2,74 & 19,0 & 26,6 & 23,4 & 3,44 & 2,9 & 4,3 & 3,3 & 0,8 \\
\hline Total & 100,0 & 16,0 & 55,4 & 6,85 & 2,11 & 4,41 & 0,79 & 7,31 & 100,0 & 100,0 & 100,0 & 100,0 & 15,2 & 16,2 & 14,2 & 24,3 \\
\hline$-19,1+12,7$ & & & & & & & & & & & & & & & & \\
\hline$d<1,7$ & 16,7 & 4,6 & $\ldots$ & $\ldots$ & $\ldots$ & $\ldots$ & $\ldots$ & $\ldots$ & $\ldots$ & $\ldots$ & $\ldots$ & $\ldots$ & $\ldots$ & $\ldots$ & $\ldots$ & $\ldots$ \\
\hline $1,9<d<2,2$ & 44,5 & 12,1 & 64,6 & 6,63 & 2,70 & 8,05 & 1,28 & 13,6 & 52,0 & 40,8 & 46,8 & 70,8 & 14,2 & 11,5 & 13,7 & 16,8 \\
\hline $2,2<d<2,5$ & 22,9 & 6,2 & 68,8 & 9,34 & 2,62 & 5,11 & 0,74 & 8,27 & 28,5 & 29,5 & 23,4 & 23,1 & 7,8 & 8,3 & 6,8 & 5,5 \\
\hline$d>2,5$ & 15,9 & 4,3 & 67,6 & 13,5 & 4,81 & 1,94 & 1,33 & 3,25 & 19,5 & 29,7 & 29,8 & 6,10 & 5,3 & 8,4 & 8,7 & 1,4 \\
\hline Total & 100,0 & 27,3 & 55,3 & 7,24 & 2,57 & 5,06 & 0,95 & 8,46 & 100,0 & 100,0 & 100,0 & 100,0 & 27,3 & 28,2 & 29,3 & 23,7 \\
\hline$-12,7+9,5$ & & & & & & & & & & & & & & & & \\
\hline$d<1,7$ & 10,3 & 0,8 & $\ldots$ & $\ldots$ & $\ldots$ & $\ldots$ & $\ldots$ & $\ldots$ & $\ldots$ & $\ldots$ & $\ldots$ & $\ldots$ & $\ldots$ & $\ldots$ & $\ldots$ & $\ldots$ \\
\hline $1,9<d<2,2$ & 24,4 & 1,9 & 60,5 & 9,08 & 3,00 & 7,50 & 1,40 & 15,6 & 25,1 & 25,0 & 26,1 & 39,3 & 1,9 & 2,2 & 2,2 & 3,6 \\
\hline $2,2<d<2,5$ & 58,2 & 4,5 & 67,7 & 9,81 & 2,87 & 4,61 & 0,80 & 9,28 & 67,0 & 64,2 & 59,5 & 57,5 & 5,2 & 5,6 & 4,9 & 5,3 \\
\hline$d>2,5$ & 7,0 & 0,5 & 66,1 & 13,8 & 5,79 & 2,16 & 1,71 & 3,09 & 7,87 & 10,9 & 14,4 & 3,24 & 0,6 & 0,9 & 1,2 & 0,3 \\
\hline Total & 100,0 & 7,7 & 58,8 & 8,90 & 2,81 & 4,67 & 0,93 & 9,43 & 100,0 & 100,0 & 100,0 & 100,0 & 7,7 & 8,7 & 8,3 & 9,2 \\
\hline$-9,5+4,8$ & & & & & & & & & & & & & & & & \\
\hline$d<1,7$ & 2,6 & 0,2 & $\ldots$ & $\ldots$ & $\ldots$ & $\ldots$ & $\ldots$ & $\ldots$ & $\ldots$ & $\ldots$ & $\ldots$ & $\ldots$ & $\ldots$ & $\ldots$ & $\ldots$ & $\ldots$ \\
\hline $1,9<d<2,2$ & 57,8 & 5,4 & 60,8 & 10,9 & 3,57 & 6,84 & 1,16 & 13,5 & 55,6 & 60,5 & 62,7 & 75,0 & 5,1 & 5,5 & 5,2 & 8,1 \\
\hline $2,2<d<2,5$ & 16,4 & 1,5 & 68,9 & 8,86 & 2,51 & 5,30 & 0,82 & 8,05 & 17,9 & 14,0 & 12,5 & 16,5 & 1,6 & 1,3 & 1,0 & 1,8 \\
\hline$d>2,5$ & 23,2 & 2,2 & 72,1 & 11,5 & 3,51 & 1,92 & 0,86 & 3,25 & 26,4 & 25,6 & 24,7 & 8,44 & 2,4 & 2,3 & 2,0 & 0,9 \\
\hline Total & 100,0 & 9,4 & 63,2 & 10,4 & 3,29 & 5,27 & 1,00 & 9,88 & 100,0 & 100,0 & 100,0 & 100,0 & 9,11 & 9,14 & 8,25 & 10,73 \\
\hline$-4,8+2,4$ & & & & & & & & & & & & & & & & \\
\hline$d<1,7$ & 1,0 & 0,1 & $\ldots$ & $\ldots$ & $\ldots$ & $\ldots$ & $\ldots$ & $\ldots$ & $\ldots$ & $\ldots$ & $\ldots$ & $\ldots$ & $\ldots$ & $\ldots$ & $\ldots$ & $\ldots$ \\
\hline $1,9<d<2,2$ & 27,4 & 1,6 & 59,3 & 12,4 & 3,77 & 6,81 & 1,23 & 13,6 & 23,9 & 36,1 & 31,7 & 39,2 & 1,3 & 2,2 & 2,0 & 2,3 \\
\hline $2,2<d<2,5$ & 41,7 & 2,4 & 68,7 & 8,25 & 3,02 & 5,63 & 0,91 & 9,78 & 42,1 & 36,6 & 38,7 & 49,4 & 2,4 & 2,2 & 2,4 & 2,9 \\
\hline$d>2,5$ & 29,9 & 1,7 & 77,3 & 8,60 & 3,23 & 1,82 & 0,66 & 2,86 & 34,0 & 27,3 & 29,6 & 11,4 & 1,9 & 1,7 & 1,8 & 0,7 \\
\hline Total & 100,0 & 5,7 & 68,0 & 9,41 & 3,26 & 4,76 & 0,91 & 8,66 & 100,0 & 100,0 & 100,0 & 100,0 & 5,6 & 6,0 & 6,2 & 5,9 \\
\hline$-2,4+1,2$ & & & & & & & & & & & & & & & & \\
\hline & 0,5 & & & $\ldots$ & & $\ldots$ & $\ldots$ & $\ldots$ & $\ldots$ & $\ldots$ & $\ldots$ & $\ldots$ & $\ldots$ & $\ldots$ & $\ldots$ & $\ldots$ \\
\hline $1,9<d<2,2$ & 3,1 & 0,2 & 50,1 & 15,7 & 4,33 & 8,64 & 1,54 & 16,7 & 2,01 & 6,82 & 4,68 & 8,44 & 0,1 & 0,3 & 0,2 & 0,3 \\
\hline $2,2<d<2,5$ & 48,1 & 2,4 & 70,1 & 9,21 & 2,84 & 5,14 & 0,80 & 8,50 & 43,7 & 62,1 & 47,7 & 78,0 & 2,4 & 2,5 & 2,1 & 2,6 \\
\hline$d>2,5$ & 48,3 & 2,4 & 86,9 & 4,60 & 2,83 & 0,89 & 0,26 & 1,78 & 54,3 & 31,1 & 47,6 & 13,5 & 2,9 & 1,2 & 2,0 & 0,5 \\
\hline Total & 100,0 & 4,9 & 77,2 & 7,14 & 2,87 & 3,17 & 0,56 & 5,47 & 100,0 & 100,0 & 100,0 & 100,0 & 5,4 & 4,0 & 4,3 & 3,4 \\
\hline$-1,2+0,3$ & & & & & & & & & & & & & & & & \\
\hline$d<1,7$ & 0,2 & 0,0 & $\ldots$ & $\ldots$ & $\ldots$ & $\ldots$ & $\ldots$ & $\ldots$ & $\ldots$ & $\ldots$ & $\ldots$ & $\ldots$ & $\ldots$ & $\ldots$ & $\ldots$ & $\ldots$ \\
\hline $1,9<d<2,2$ & 1,3 & 0,1 & 52,2 & 15,5 & 4,94 & 7,00 & 1,35 & 15,1 & 0,83 & 4,42 & 2,83 & 4,85 & 0,1 & 0,3 & 0,2 & 0,2 \\
\hline $2,2<d<2,5$ & 35,7 & 3,9 & 75,3 & 8,25 & 2,22 & 3,85 & 0,65 & 5,80 & 31,7 & 62,2 & 33,7 & 70,6 & 4,2 & 3,5 & 2,6 & 3,3 \\
\hline$d>2,5$ & 62,7 & 6,9 & 91,0 & 2,52 & 2,38 & 0,76 & 0,18 & 1,44 & 67,4 & 33,4 & 63,5 & 24,5 & 9,0 & 1,9 & 4,9 & 1,1 \\
\hline Total & 100,0 & 11,0 & 84,7 & 4,73 & 2,35 & 1,94 & 0,36 & 3,18 & 100,0 & 100,0 & 100,0 & 100,0 & 13,3 & 5,7 & 7,7 & 4,6 \\
\hline Total $+0,30$ & & & & & & & & & & & & & & & & \\
\hline & 10,8 & & . & $\ldots$ & . & . & $\ldots$ & . & . & $\ldots$ & $\ldots$ & $\ldots$ & $\ldots$ & $\ldots$ & $\ldots$ & $\ldots$ \\
\hline $1,9<d<2,2$ & 34,2 & 28,0 & 63,6 & 8,13 & 2,91 & 7,59 & 1,23 & 13,5 & 34,7 & 37,1 & 38,0 & 59,5 & 30,4 & 28,9 & 30,4 & 48,9 \\
\hline $2,2<d<2,5$ & 30,2 & 24,7 & 70,2 & 9,02 & 2,63 & 4,79 & 0,77 & 8,04 & 33,8 & 36,3 & 30,3 & 33,1 & 28,2 & 28,3 & 23,7 & 27,2 \\
\hline$d>2,5$ & 24,9 & 20,4 & 79,6 & 8,01 & 3,35 & 1,31 & 0,66 & 2,37 & 31,5 & 26,6 & 31,7 & 7,44 & 25,0 & 20,7 & 24,0 & 5,7 \\
\hline Total & 100,0 & 82,0 & 62,7 & 7,49 & 2,62 & 4,37 & 0,82 & 7,62 & 100,0 & 100,0 & 100,0 & 100,0 & 83,7 & 77,9 & 78,2 & 81,9 \\
\hline$-25,4+4,8$ & & & & & & & & & & & & & & & & \\
\hline$d<1,7$ & 14,5 & 8,7 & $\ldots$ & $\ldots$ & & $\ldots$ & $\ldots$ & $\ldots$ & $\ldots$ & $\ldots$ & $\ldots$ & $\ldots$ & $\ldots$ & $\ldots$ & $\ldots$ & $\ldots$ \\
\hline $1,9<d<2,2$ & 43,4 & 26,2 & 64,0 & 7,79 & 2,84 & 7,64 & 1,23 & 13,4 & 48,7 & 43,1 & 47,6 & 68,0 & 28,9 & 26,2 & 28,0 & 46,1 \\
\hline $2,2<d<2,5$ & 26,6 & 16,1 & 69,2 & 9,29 & 2,64 & 4,85 & 0,77 & 8,26 & 32,3 & 31,5 & 27,1 & 26,5 & 19,2 & 20,1 & 16,7 & 18,4 \\
\hline$d>2,5$ & 15,5 & 9,4 & 69,7 & 12,8 & 4,21 & 1,72 & 1,12 & 3,11 & 19,0 & 25,4 & 25,3 & 5,50 & 11,2 & 16,0 & 15,3 & 3,5 \\
\hline Total & 100,0 & 60,4 & 57,0 & 7,84 & 2,59 & 4,87 & 0,91 & 8,50 & 100,0 & 100,0 & 100,0 & 100,0 & 59,3 & 62,2 & 60,0 & 68,0 \\
\hline$-4,8+0,3$ & & & & & & & & & & & & & & & & \\
\hline$d<1,7$ & 0,5 & 0,1 & $\ldots$ & $\ldots$ & $\ldots$ & $\ldots$ & $\ldots$ & $\ldots$ & $\ldots$ & $\ldots$ & $\ldots$ & $\ldots$ & $\ldots$ & $\ldots$ & $\ldots$ & $\ldots$ \\
\hline $1,9<d<2,2$ & 8,6 & 1,9 & 58,0 & 12,9 & 3,91 & 6,97 & 1,26 & 14,0 & 6,35 & 17,1 & 12,4 & 20,2 & 1,6 & 2,7 & 2,4 & 2,8 \\
\hline $2,2<d<2,5$ & 40,1 & 8,7 & 72,1 & 8,51 & 2,61 & 4,69 & 0,76 & 7,63 & 36,8 & 52,4 & 38,6 & 63,4 & 9,0 & 8,2 & 7,0 & 8,8 \\
\hline$d>2,5$ & 50,8 & 11,0 & 88,0 & 3,91 & 2,61 & 0,95 & 0,27 & 1,73 & 56,9 & 30,5 & 49,0 & 16,3 & 13,8 & 4,8 & 8,8 & 2,3 \\
\hline Total & 100,0 & 21,6 & 78,6 & 6,51 & 2,71 & 2,96 & 0,55 & 5,14 & 100,0 & 100,0 & 100,0 & 100,0 & 24,4 & 15,7 & 18,2 & 13,9 \\
\hline
\end{tabular}


Os agregados VI-V apresentam teores de sílica, alumina e $\mathrm{Fe}_{2} \mathrm{O}_{3}$ são pouco variáveis em função da densidade dos produtos, em média, 62,7, 7,5 2,6\%. O teor de $\mathrm{CaO}$ varia bruscamente com o intervalo de densidade, de 7,6 para $\mathrm{d}<1,9 \mathrm{~g} / \mathrm{cm}^{3}$ a $1,3 \%$ para o mais denso; de forma análoga comporta-se o $\mathrm{MgO}$, com teores entre 1,2 e $0,7 \%$. A perda ao fogo decresce com o aumento da densidade, entre 13,5 e $2,4 \%$, em média.
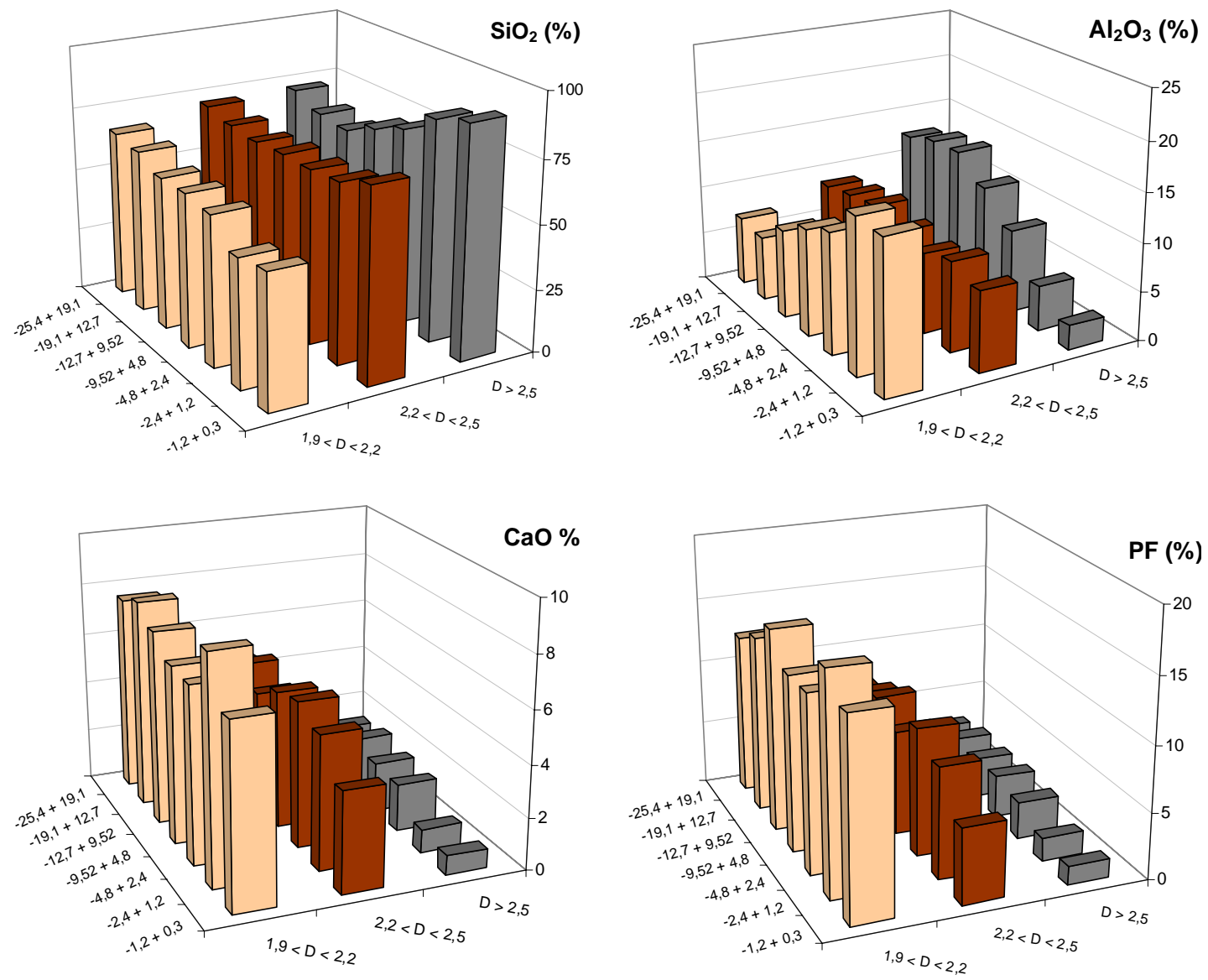

Figura 5.7 - Comparação entre teores dos principais óxidos para os para os produtos de separação em líquidos densos: VI-V

\subsubsection{Comparação entre os produtos de separações em líquidos densos}

Os teores dos principais óxidos são fortemente influenciados pela faixa de densidade (Figuras 5.5 a 5.7); as Figuras 5.8 a 5.11 comparam os teores dos principais óxidos e da perda ao fogo para os três agregados reciclados estudados em função da faixa de densidade. 

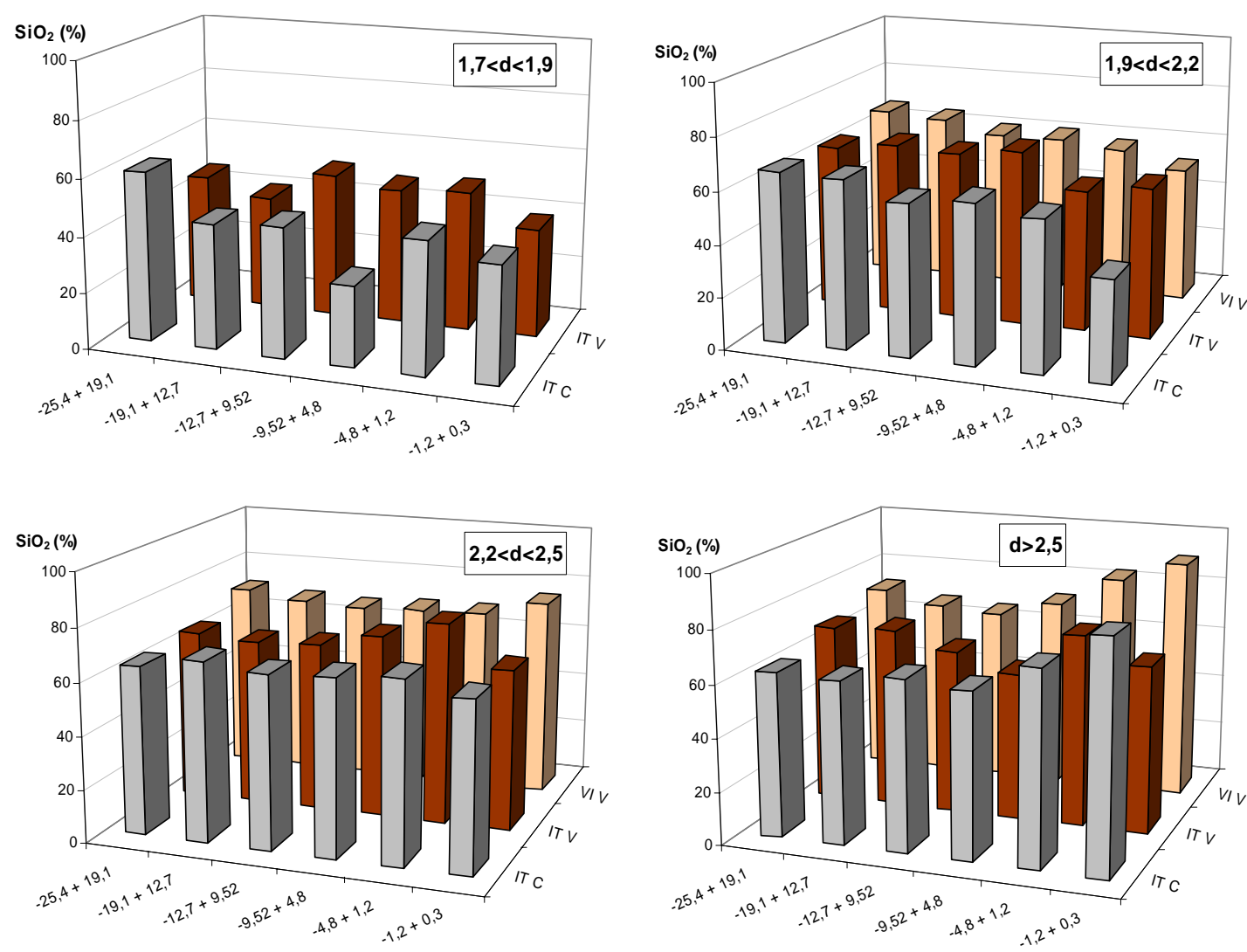

Figura 5.8 - Comparação entre teores de sílica por faixa densitária

Para as três amostras estudadas o teor médio de sílica é pouco variável nas densidades superiores a $1,9 \mathrm{~cm}^{3}$ (de 55 a $80 \%$ nos produtos de Itaquera e 60 a $90 \%$ em VI-V), com notável empobrecimento para o produto $1,7<\mathrm{d}<1,9$ de Itaquera (média de 43\%); os teores apresentam poucas variações entre as amostras estudadas, sendo assim infere-se que o teor de $\mathrm{SiO}_{2}$ é fortemente influenciado pela densidade, mais do que a classe ou origem dos agregados. Destaca-se para o produto $\mathrm{d}>2,5$ a elevação dos teores nas frações mais finas (aumento do conteúdo de quartzo liberado e fragmentos de rocha). 

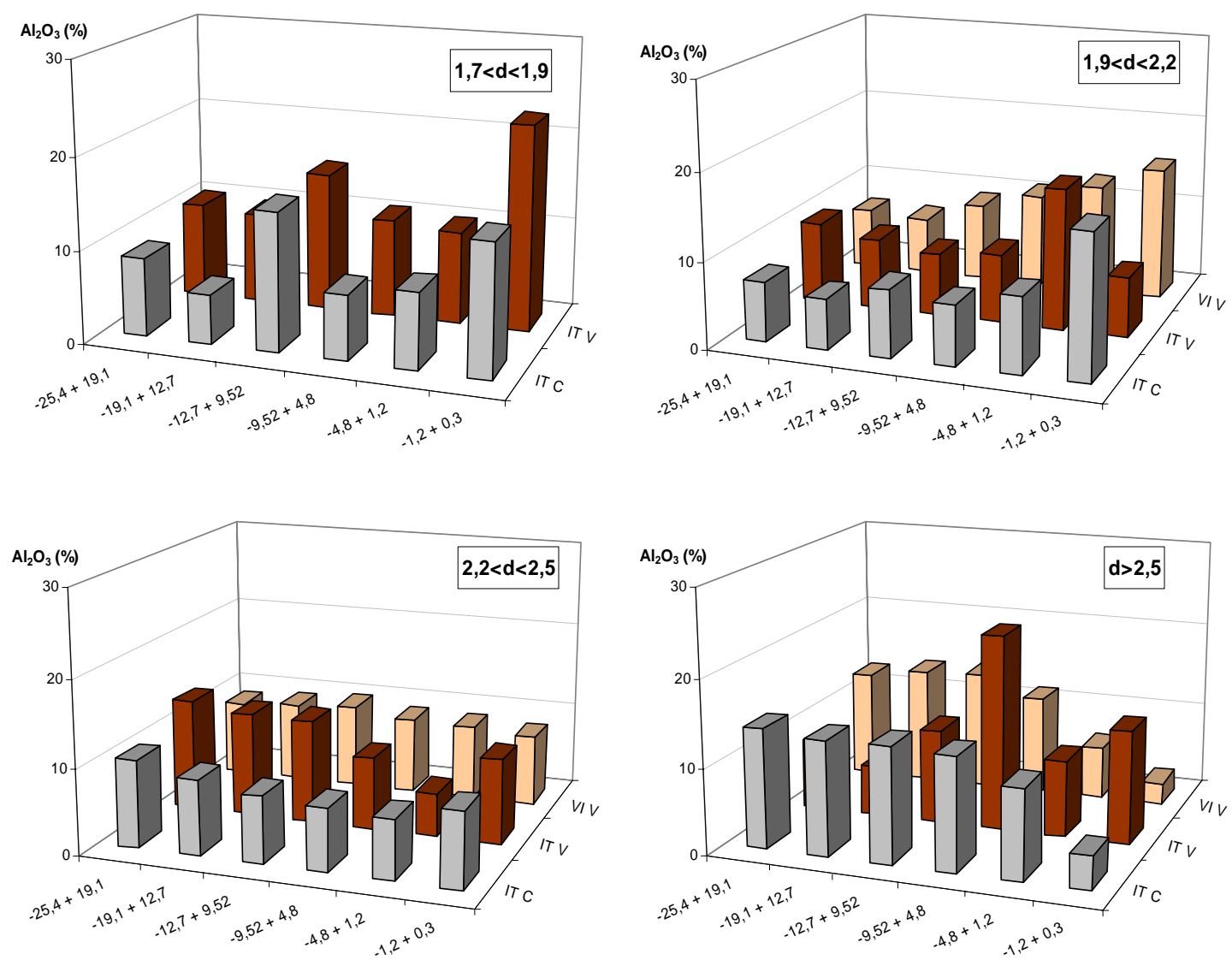

Figura 5.9 - Comparação entre teores de alumina por faixa densitária

$\mathrm{O}$ produto IT-C e IT-V (teores médios de 6,6 e 10,0\% de $\mathrm{Al}_{2} \mathrm{O}_{3}$, respectivamente) apresentam um comportamento bastante irregular para os produtos de densidade inferior a $1,9 \mathrm{~g} / \mathrm{cm}^{3}$, com maior enriquecimento de alumina na fração fina, tendência esta também observada para os produtos contidos no intervalo $1,9<\mathrm{d}<2,2$. Para os produtos $2,2<\mathrm{d}<2,5$ os teores não apresentam variações tão expressivas na granulometria e são muito semelhantes entre as três amostras estudadas. Os teores de alumina nos produtos mais densos IT-C e VI-V são similares para as frações acima de 1,2 $\mathrm{mm}$ e decrescem no passante; já para IT-V os teores apresentam maiores variações, aumentando na fração passante em 1,2 mm e -9,52+4,8 mm. 

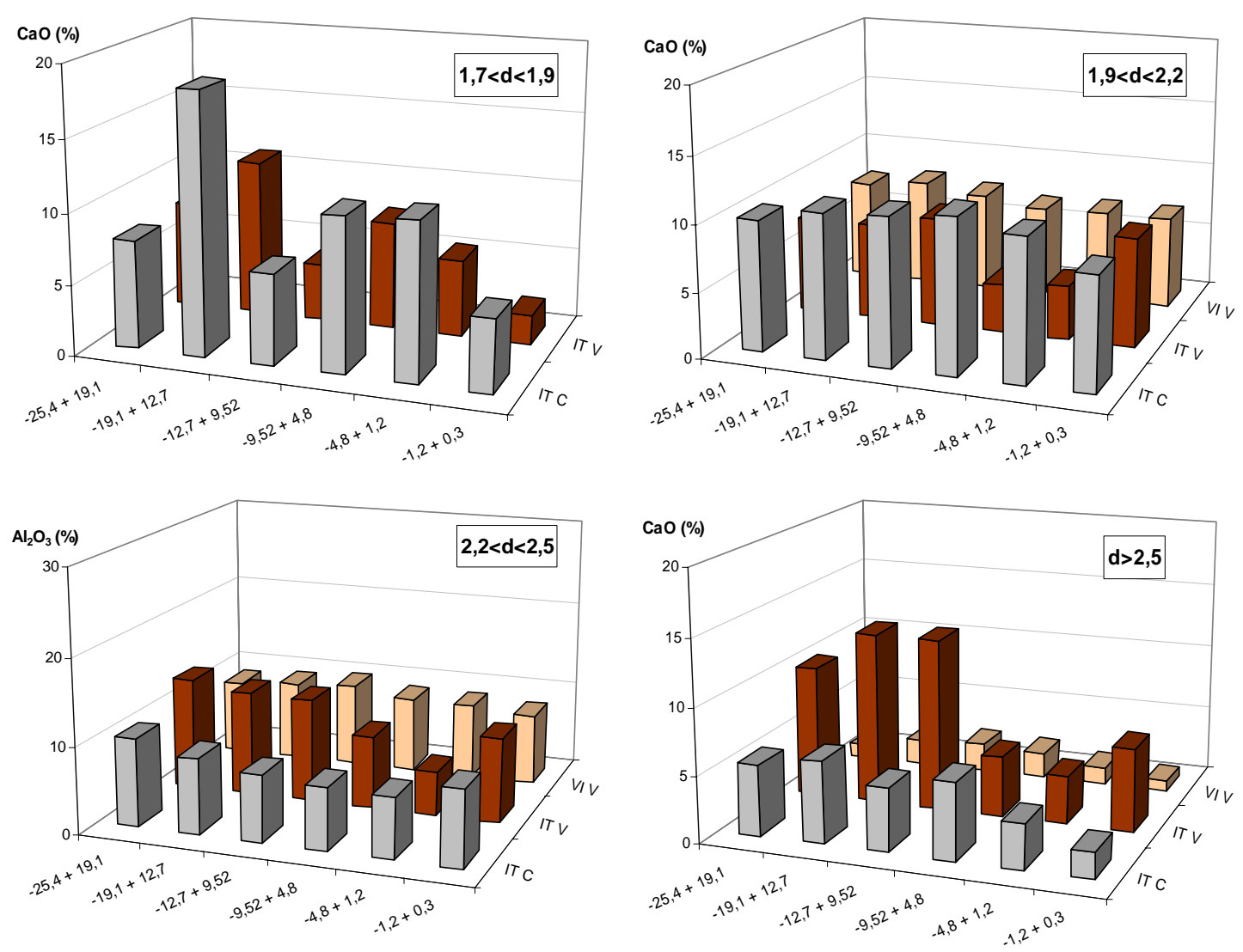

Figura 5.10 - Comparação entre teores de $\mathrm{CaO}$ por faixa densitária

Os teores de $\mathrm{CaO}$ não seguem um comportamento muito regular nas frações granulométricas, sendo que o produto $1,7<\mathrm{d}<1,9$ apresenta comportamento mais irregular. Nos demais intervalos de densidade IT-C e VI-V apresentam teores de $\mathrm{CaO}$ mais homogêneos, decrescentes para os produtos de menor densidade, já IT-V tem um comportamento bastante irregular com notável enriquecimento na fração $-25,4+9,52 \mathrm{~mm}$ e $\mathrm{d}>2,5 \mathrm{~g} / \mathrm{cm}^{3}$ e teores significativamente inferiores para os produtos $2,2<\mathrm{d}<2,5$.

Os teores médios de perda ao fogo por intervalo crescente de densidade são de: $23-26 \% ; 12-14 \% ; 8-9 \% ; 2-4 \%$; nota-se claramente que a perda ao fogo é diretamente influenciada pela densidade média dos produtos. 

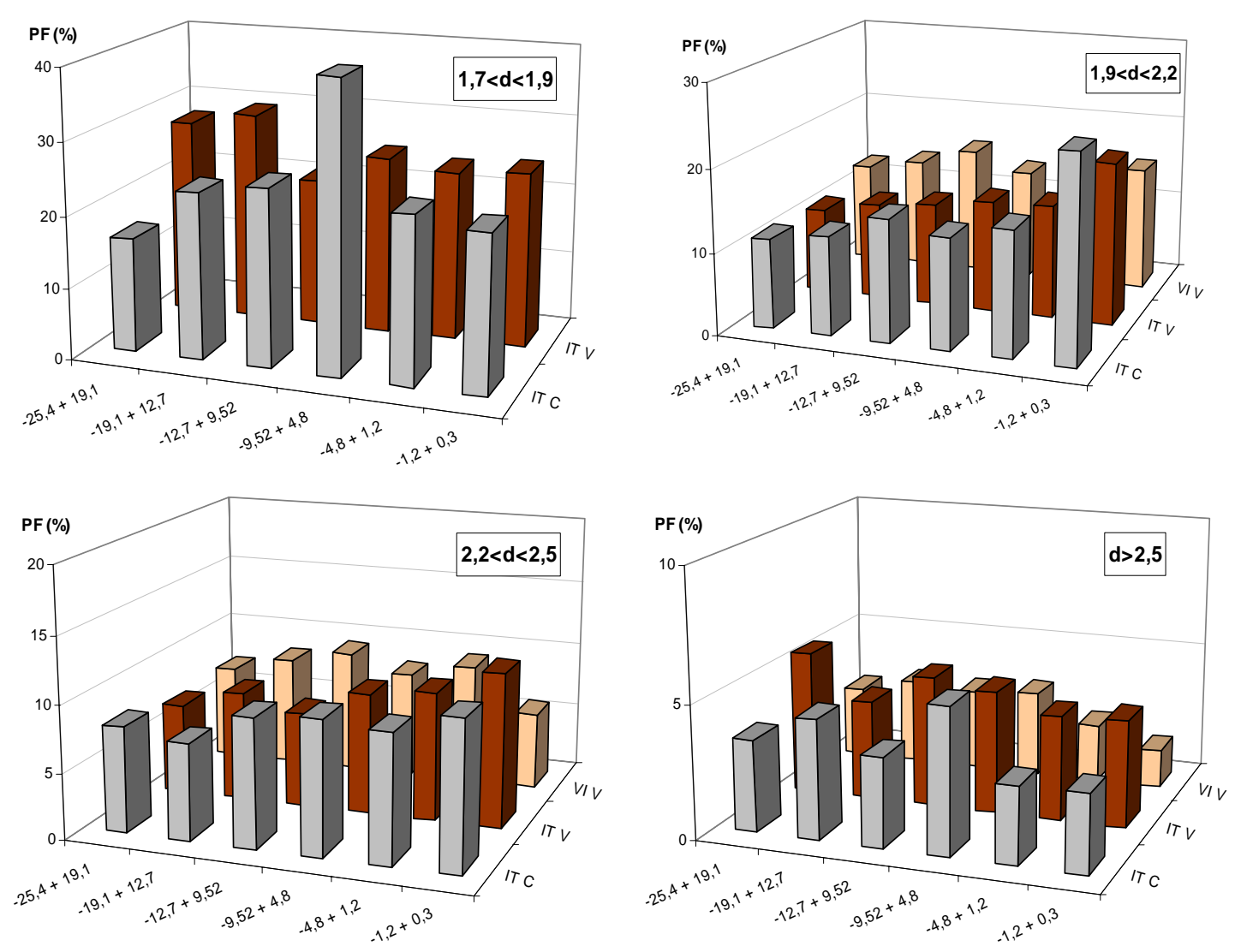

Figura 5.11 - Comparação entre teores de perda ao fogo por faixa densitária

\subsubsection{Resíduo insolúvel}

Os teores de resíduo insolúvel (RI) e de aglomerantes para os produtos de separações por densidade das três amostras ensaiadas são apresentados nas Tabelas 5.7 a 5.9. As médias dos teores de RI e aglomerantes para cada amostra, nos intervalos de densidade considerados, são sumariadas nas Figuras 5.12 e 5.13.

O resíduo insolúvel assim como os teores de aglomerantes são essencialmente variáveis em função da densidade, independentemente da granulometria; apresentam comportamentos inversos com o conteúdo de aglomerantes crescente para os produtos de menor densidade. Os agregados de Itaquera são muito semelhantes neste quesito; já o agregado reciclado VI-V é o que apresenta maior resíduo insolúvel e, portanto, menor teor de aglomerantes em todas as faixas densitárias. 
Tabela 5.7 - Teores de resíduo insolúvel e de aglomerantes; IT-C

\begin{tabular}{|c|ccc|ccc|}
\hline Itaquera Cinza & \multicolumn{3}{|c|}{$\mathrm{RI}(\%)$} & \multicolumn{3}{c|}{ Teor de aglomerantes (\%) } \\
Fração $(\mathrm{mm})$ & $1,9<\mathrm{d}<2,2$ & $2,2<\mathrm{d}<2,5$ & $\mathrm{~d}>2,5$ & $1,9<\mathrm{d}<2,2$ & $2,2<\mathrm{d}<2,5$ & $\mathrm{~d}>2,5$ \\
\hline$-25,4+19,1 \mathrm{~mm}$ & 78,5 & 81,9 & 86,9 & 21,5 & 18,1 & 13,1 \\
$-19,1+12,7 \mathrm{~mm}$ & 76,1 & 83,0 & 84,6 & 23,9 & 17,0 & 15,4 \\
$-12,7+9,5 \mathrm{~mm}$ & 72,5 & 79,5 & 90,0 & 27,5 & 20,5 & 9,97 \\
$-9,5+4,8 \mathrm{~mm}$ & 68,9 & 80,2 & 84,4 & 31,1 & 19,8 & 15,6 \\
$-4,8+1,2 \mathrm{~mm}$ & 72,2 & 81,4 & 91,6 & 27,9 & 18,6 & 8,43 \\
$-1,2+0,3 \mathrm{~mm}$ & - & 77,8 & 91,7 & - & 22,2 & 8,30 \\
Média** & $\mathbf{7 4 , 0}$ & $\mathbf{8 1 , 0}$ & $\mathbf{8 7 , 9}$ & 26,0 & 19,0 & 12,1 \\
\hline
\end{tabular}

** Média ponderada pelas proporções em massa de cada fração granulométrica

Tabela 5.8 - Teores de resíduo insolúvel e de aglomerantes; IT-V

\begin{tabular}{|c|ccc|ccc|}
\hline Itaquera & \multicolumn{3}{|c|}{ RI (\%) } & \multicolumn{3}{c|}{ Teor de aglomerantes (\%) } \\
Fração $(\mathrm{mm})$ & $1,9<\mathrm{d}<2,2$ & $2,2<\mathrm{d}<2,5$ & $\mathrm{~d}>2,5$ & $1,9<\mathrm{d}<2,2$ & $2,2<\mathrm{d}<2,5$ & $\mathrm{~d}>2,5$ \\
\hline$-25,4+19,1 \mathrm{~mm}$ & 76,3 & 82,7 & 85,0 & 23,7 & 17,3 & 15,0 \\
$-19,1+12,7 \mathrm{~mm}$ & 75,6 & 80,5 & 88,9 & 24,4 & 19,5 & 11,2 \\
$-12,7+9,5 \mathrm{~mm}$ & 73,1 & 81,5 & 86,0 & 26,9 & 18,5 & 14,1 \\
$-9,5+4,8 \mathrm{~mm}$ & 71,0 & 78,2 & 86,9 & 29,0 & 21,8 & 13,1 \\
$-4,8+1,2 \mathrm{~mm}$ & 68,9 & 82,6 & 87,5 & 31,1 & 17,4 & 12,5 \\
$-1,2+0,3 \mathrm{~mm}$ & 64,6 & 74,1 & 88,9 & 35,4 & 26,0 & 11,2 \\
Média $^{\star \star}$ & 71,1 & 80,1 & 87,3 & 28,9 & 19,9 & 12,7 \\
\hline
\end{tabular}

** Média ponderada pelas proporções em massa de cada fração granulométrica

Tabela 5.9 - Teores de resíduo insolúvel e de aglomerantes; VI-V

\begin{tabular}{|c|ccc|ccc|}
\hline Vinhedo Vermelho & \multicolumn{3}{|c|}{ RI (\%) } & \multicolumn{3}{c|}{ Teor de aglomerantes (\%) } \\
Fração $(\mathrm{mm})$ & $1,9<\mathrm{d}<2,2$ & $2,2<\mathrm{d}<2,5$ & $\mathrm{~d}>2,5$ & $1,9<\mathrm{d}<2,2$ & $2,2<\mathrm{d}<2,5$ & $\mathrm{~d}>2,5$ \\
\hline$-25,4+19,1 \mathrm{~mm}$ & 80,0 & 86,4 & 90,7 & 20,0 & 13,6 & 9,27 \\
$-19,1+12,7 \mathrm{~mm}$ & 75,9 & 84,6 & 88,4 & 24,1 & 15,4 & 11,6 \\
$-12,7+9,5 \mathrm{~mm}$ & 75,3 & 83,6 & 89,6 & 24,7 & 16,5 & 10,5 \\
$-9,5+4,8 \mathrm{~mm}$ & 76,0 & 84,5 & 88,5 & 24,0 & 15,5 & 11,5 \\
$-4,8+1,2 \mathrm{~mm}$ & 75,2 & 81,2 & 91,5 & 25,0 & 18,8 & 8,50 \\
$-1,2+0,3 \mathrm{~mm}$ & 70,2 & 82,8 & 93,6 & 29,8 & 17,2 & 6,44 \\
Média $^{\star \star}$ & 75,6 & 84,7 & 90,5 & 24,4 & 15,3 & 9,5 \\
\hline
\end{tabular}

** Média ponderada pelas proporções em massa de cada fração granulométrica 


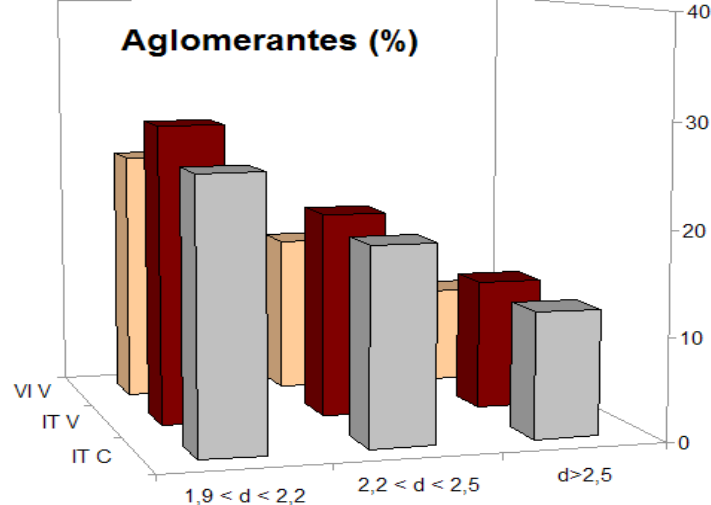

Figura 5.12 -Teores médios de RI por intervalo de densidade

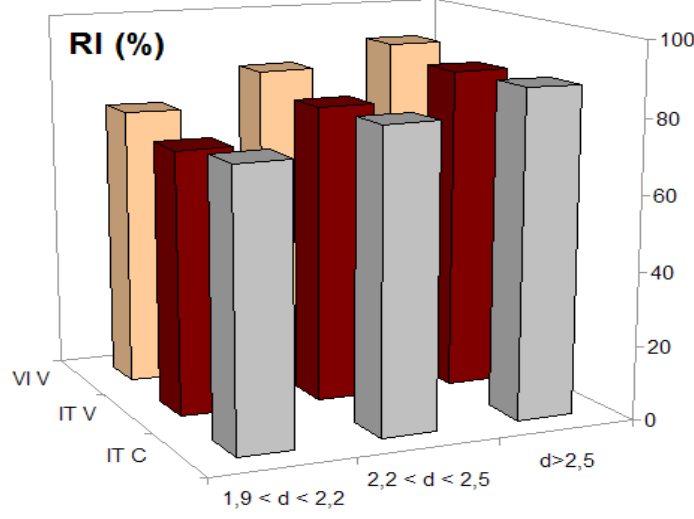

Figura 5.13 - Teores médios de aglomerantes por intervalo de densidade

\subsubsection{Sumário dos resultados}

A correlação inversamente proporcional entre os teores de $\mathrm{SiO}_{2}$ e a soma dos teores de $\mathrm{CaO}$ e $\mathrm{Al}_{2} \mathrm{O}_{3}$ é bastante semelhante entre os produtos de densidades 1,9-2,2 e 2,2-2,5 g/ $\mathrm{cm}^{3}$ (Figura 5.14a). Os teores de $\mathrm{SiO}_{2}$ estão também correlacionados com os teores de aglomerantes estimados a partir de ataque ácido (Figura 5.14 b).

Há uma relação linear (proporcional) entre a perda ao fogo e o teor de aglomerantes (Figura 5.15); assim sendo, infere-se que grande parte dos voláteis presentes (água combinada e do $\mathrm{CO}_{2}$ ) estejam diretamente associados aos aglomerantes.

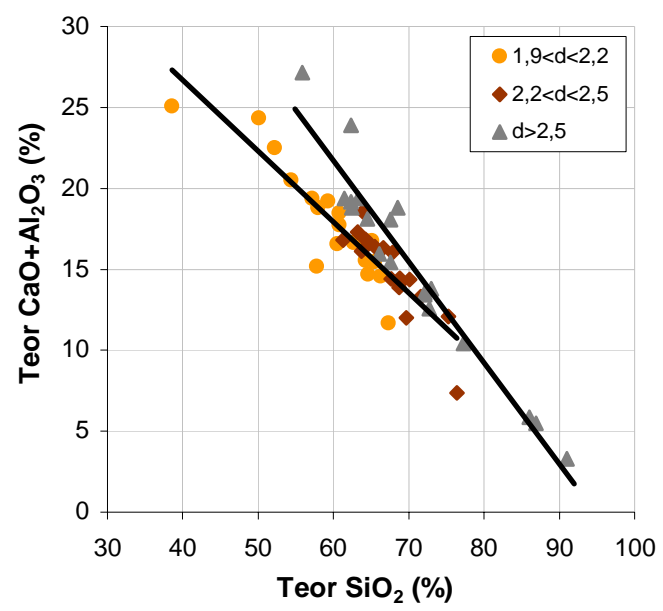

(a)

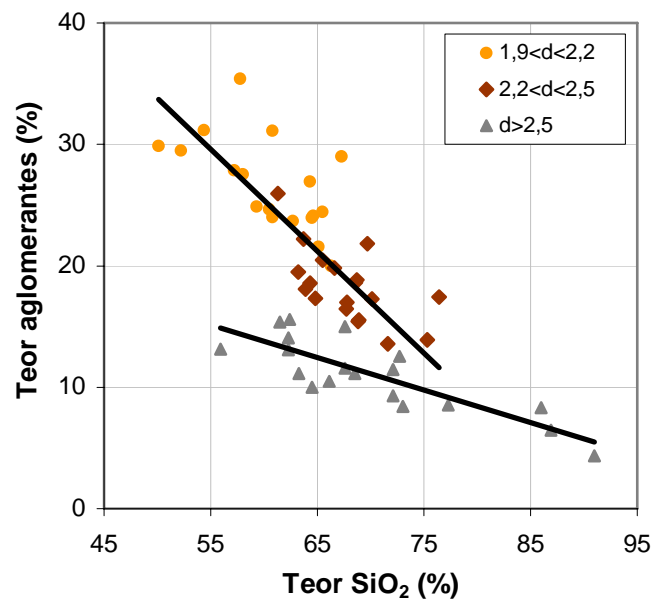

(b)

Figura 5.14 - Correlação entre os teores de $\mathrm{SiO}_{2}$ e $\mathrm{Ca}+\mathrm{Al}_{2} \mathrm{O}_{3}$ (a) e entre os teores de $\mathrm{SiO}_{2}$ e os teores estimados de aglomerantes (b) para os produtos de separação em líquidos densos 


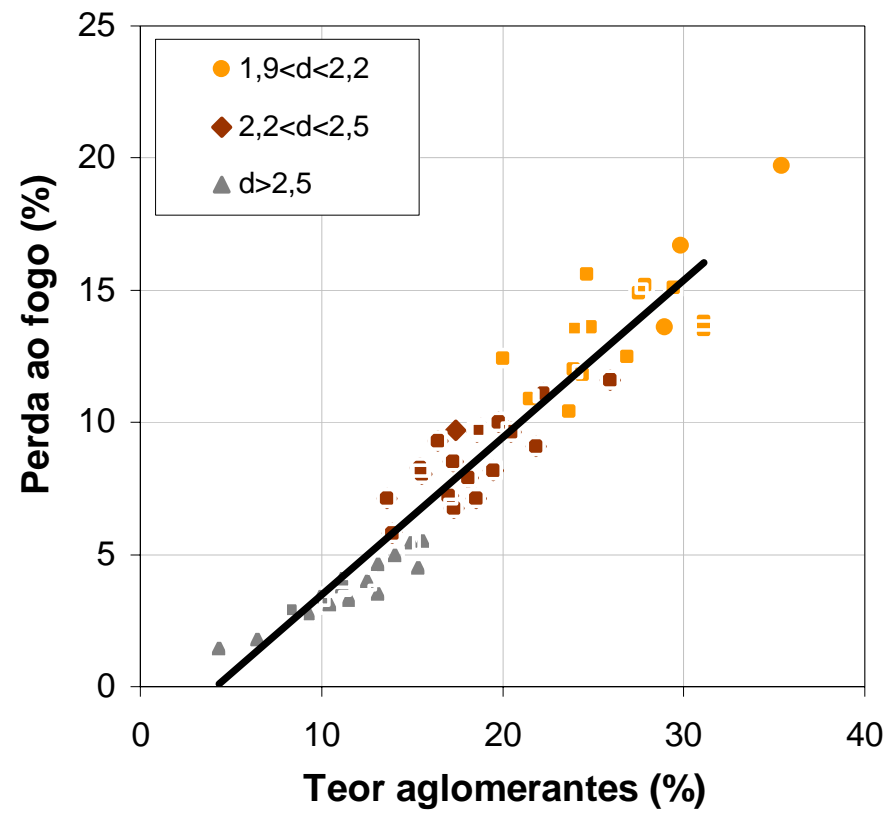

Figura 5.15 - Correlação entre os teores estimados de aglomerantes e a perda ao fogo nos produtos de separação em líquidos densos

As Figuras 5.16 e 5.17 mostram que há uma correlação bastante acentuada tanto entre os teores de aglomerantes como entre a perda ao fogo e a densidade do agregado, de modo que quanto maior a densidade, menor a perda ao fogo e logo menor o teor de aglomerantes ${ }^{16}$.

O teor de aglomerantes, bem como a perda ao fogo, são essencialmente influenciados pela densidade, sendo o tamanho da partícula mais influente para os finos $(<0,15$ $\mathrm{mm}$ ), fração na qual a composição química também se diferencia das demais.

\footnotetext{
${ }^{16}$ Mais detalhes na Caracterização Microestrutural (Cap. 6) e Caracterização das Propriedades Físicas (Cap. 7).
} 


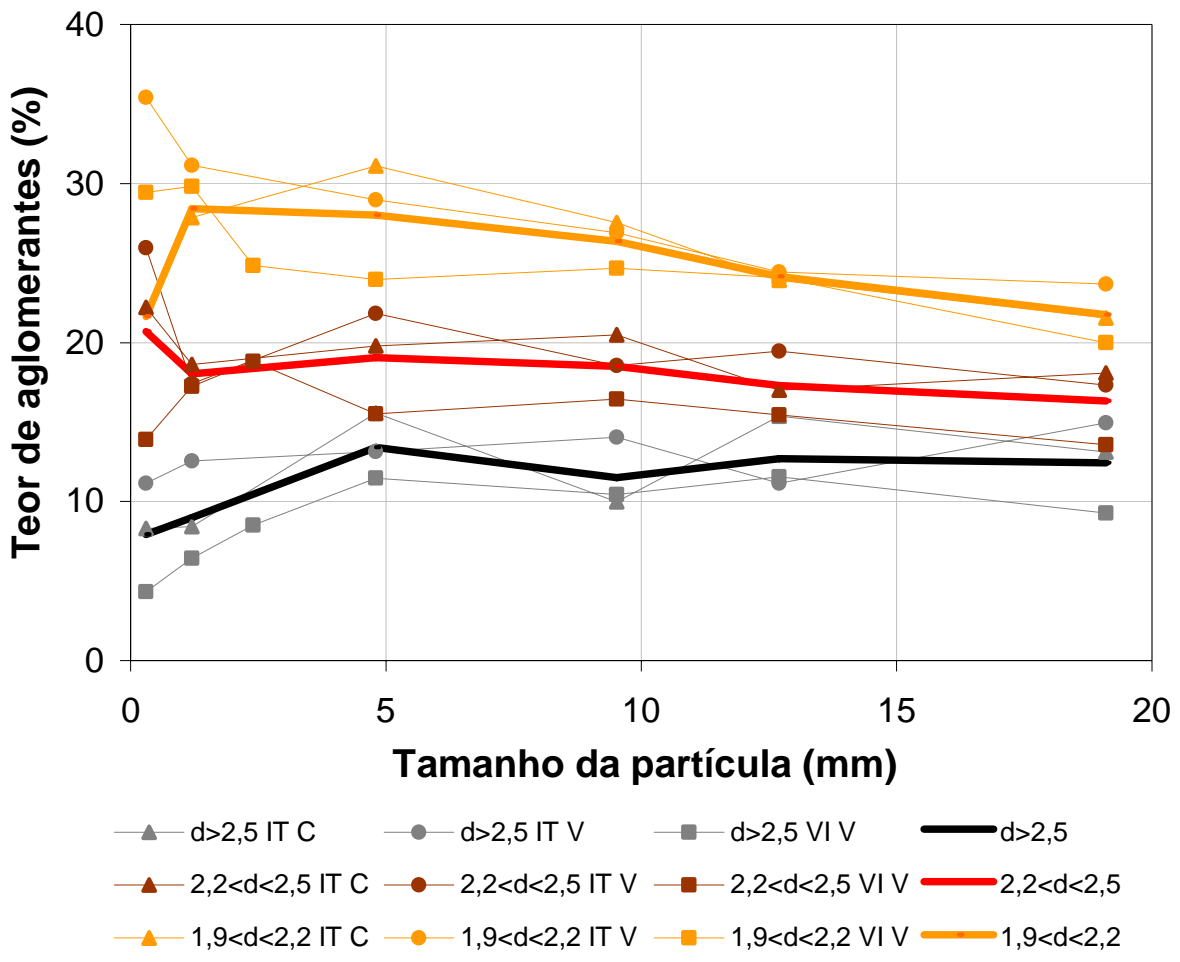

Figura 5.16 - Teores estimados de aglomerantes para as diferentes classes e origem de RCD em função da granulometria e densidade
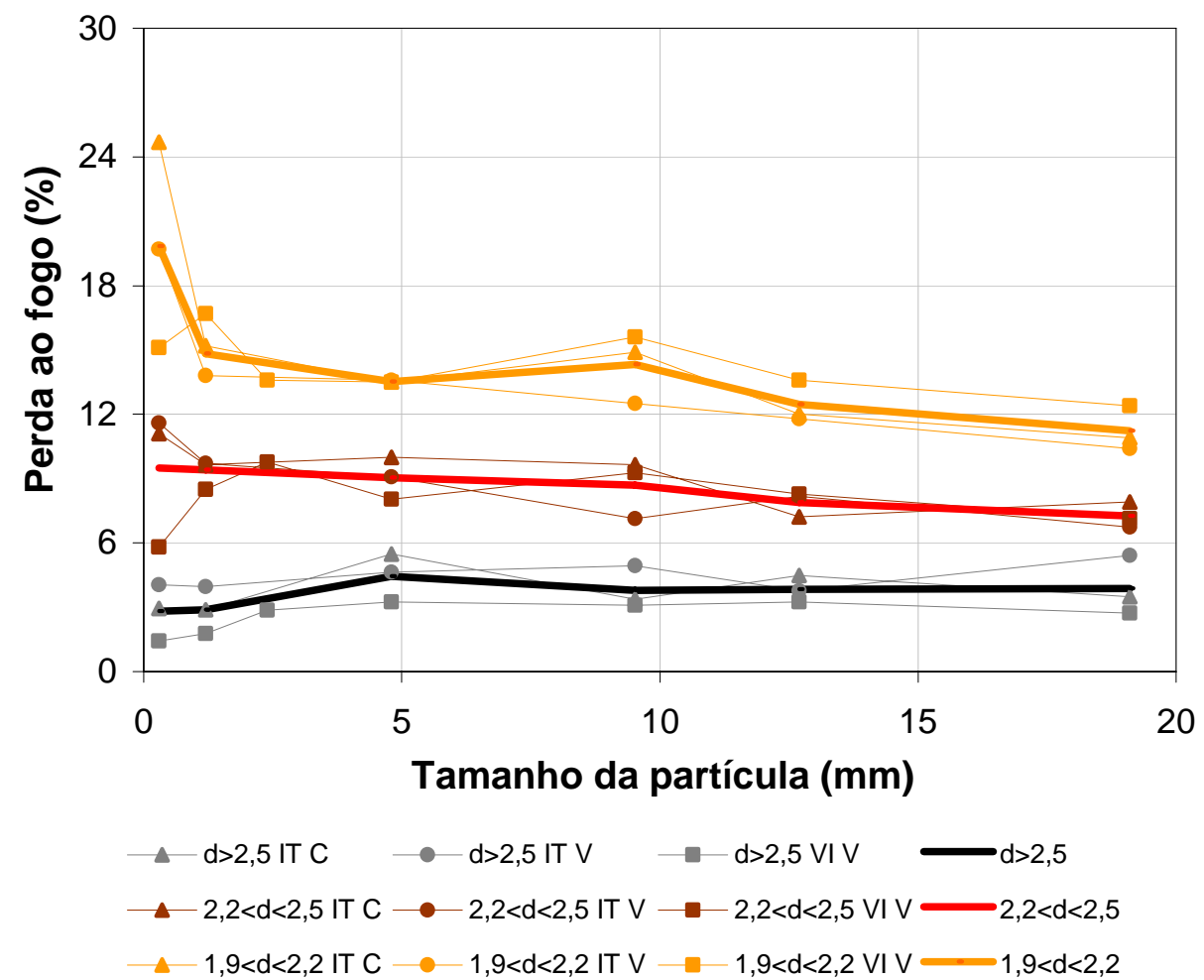

Figura 5.17 - Teores de perda ao fogo para diferentes classes e origem de RCD em função da granulometria e densidade 


\section{CARACTERIZAÇÃo MICROESTRUTURAL}

\subsection{DIFRATOMETRIA DE RAIOS $X$}

A composição mineralógica estimada para as amostras estudadas encontra-se sumariada na Tabela 6.1 e a comparação entre estas na Figura 6.1. Os difratogramas comparativos são apresentados nas Figuras 6.2 a 6.4 .

Tabela 6.1 - Composição mineralógica (em porcentagem) das frações graúda e miúda

\begin{tabular}{|c|c|c|c|c|c|c|c|c|c|c|}
\hline Fração & Am. & Feldsp. K & Albita & Quarzo & Mica & Argilm. & Gibsita & Crisotila & Calcita & Dolomita \\
\hline \multirow[t]{3}{*}{ Graúdo } & IT-C & 45 & 19 & 10 & 19 & 1 & nd & nd & 6 & nd \\
\hline & IT-V & 46 & 20 & 7 & 17 & 4 & nd & nd & 5 & nd \\
\hline & VI-V & 42 & 16 & 13 & 18 & 4 & nd & nd & 7 & nd \\
\hline \multirow[t]{3}{*}{ Miúdo } & IT-C & 48 & 18 & 10 & 16 & 3 & nd & PP & 5 & nd \\
\hline & IT-V & 40 & 22 & 15 & 16 & 3 & nd & PP & 5 & nd \\
\hline & VI-V & 44 & 17 & 12 & 19 & 4 & nd & PP & 4 & nd \\
\hline \multirow[t]{3}{*}{$-0,15$} & IT-C & 29 & 9 & 12 & 17 & 17 & 2 & PP & 14 & nd \\
\hline & IT-V & 32 & 10 & 7 & 17 & 21 & 3 & PP & 10 & nd \\
\hline & VI-V & 29 & 11 & 10 & 20 & 20 & 2 & nd & 8 & nd \\
\hline
\end{tabular}

Nota: Feldsp. K - feldspato potássico; Argilm. - argilominerais; pp - possível presença; nd - não detectado Proporções minerais estimadas a partir de difração de raios $X$, método RIR (valores semiquantiativos para fins comparativos)

Ressalta-se que o método utilizado para determinação da composição mineralógica quantitativa pode incorrer em erros significativos, porém, ainda assim a análise qualitativa indica que os minerais componentes das amostras são praticamente os mesmos para os três RCD estudados, ainda que em proporções muito distintas.

Feldspatos, tais como albita e ortoclásio/microclínio são encontrados em todas as frações, bem como calcita, mica (muscovita/biotita/flogopita) e quartzo. Nas frações mais finas ocorre um aumento significativo no teor de argilominerais, tais como caulinita; podem também estar presentes pequenas quantidades de crisotila e gibsita. Teores de caulinita na fração graúda são indicativos da presença de solo ou cerâmica em condições inadequadas de queima. 


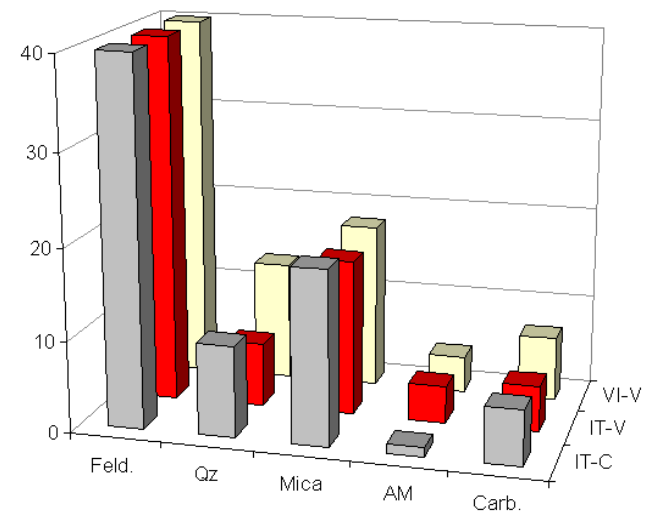

Fração graúda

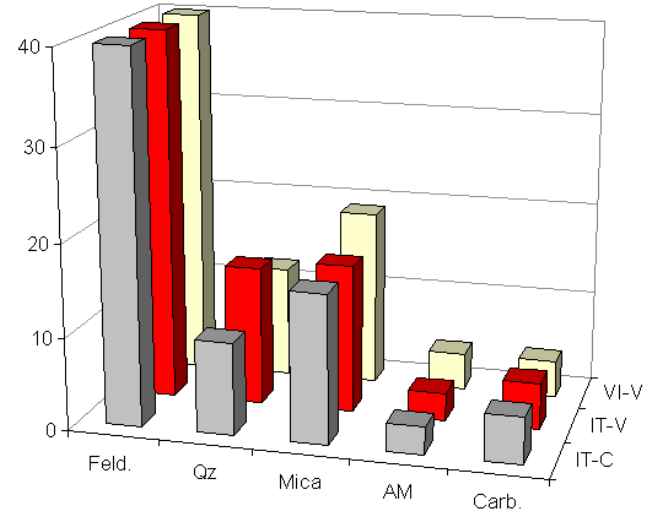

Fração Miúda

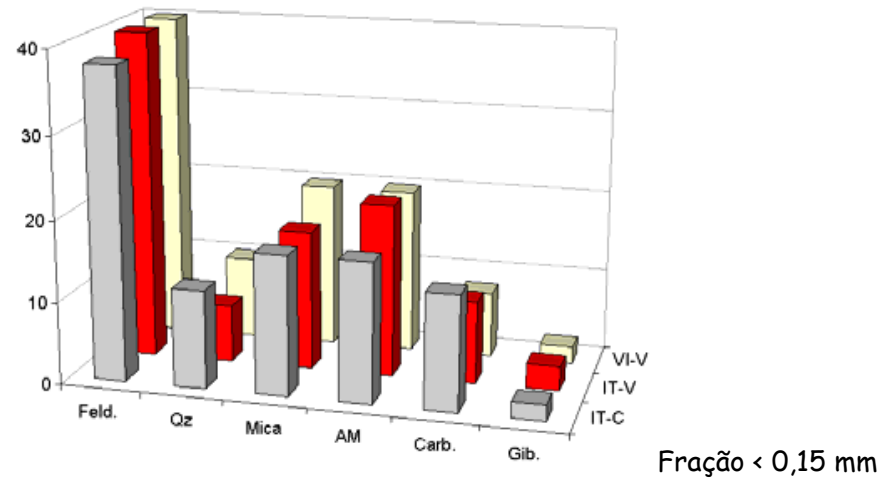

Figura 6.1 - Comparação entre composições mineralógicas das frações graúda, miúda e finos $(<0,15 \mathrm{~mm})$

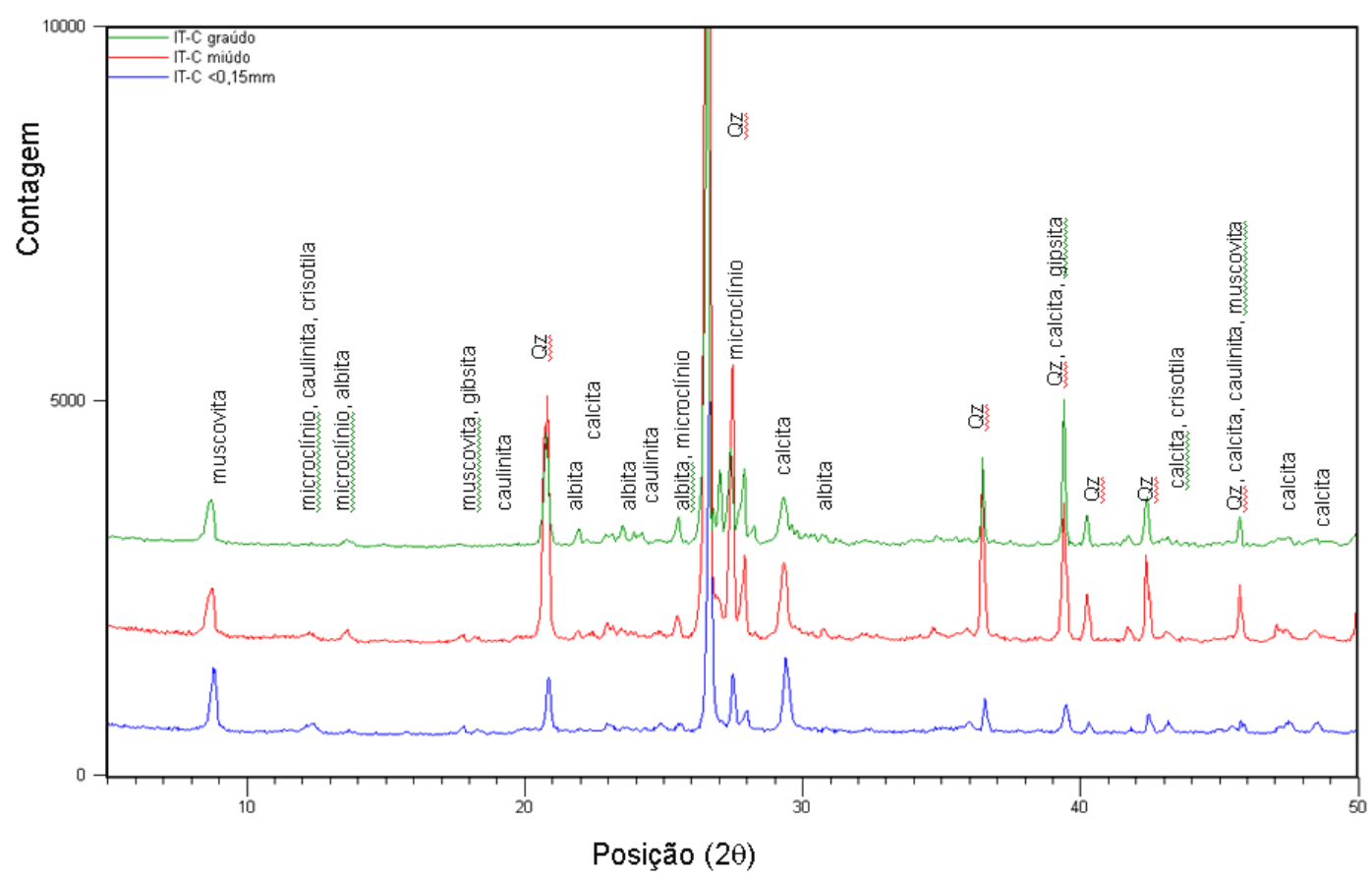

Figura 6.2 - Difratogramas comparativos referentes às frações granulométricas da amostra Itaquera Cinza 


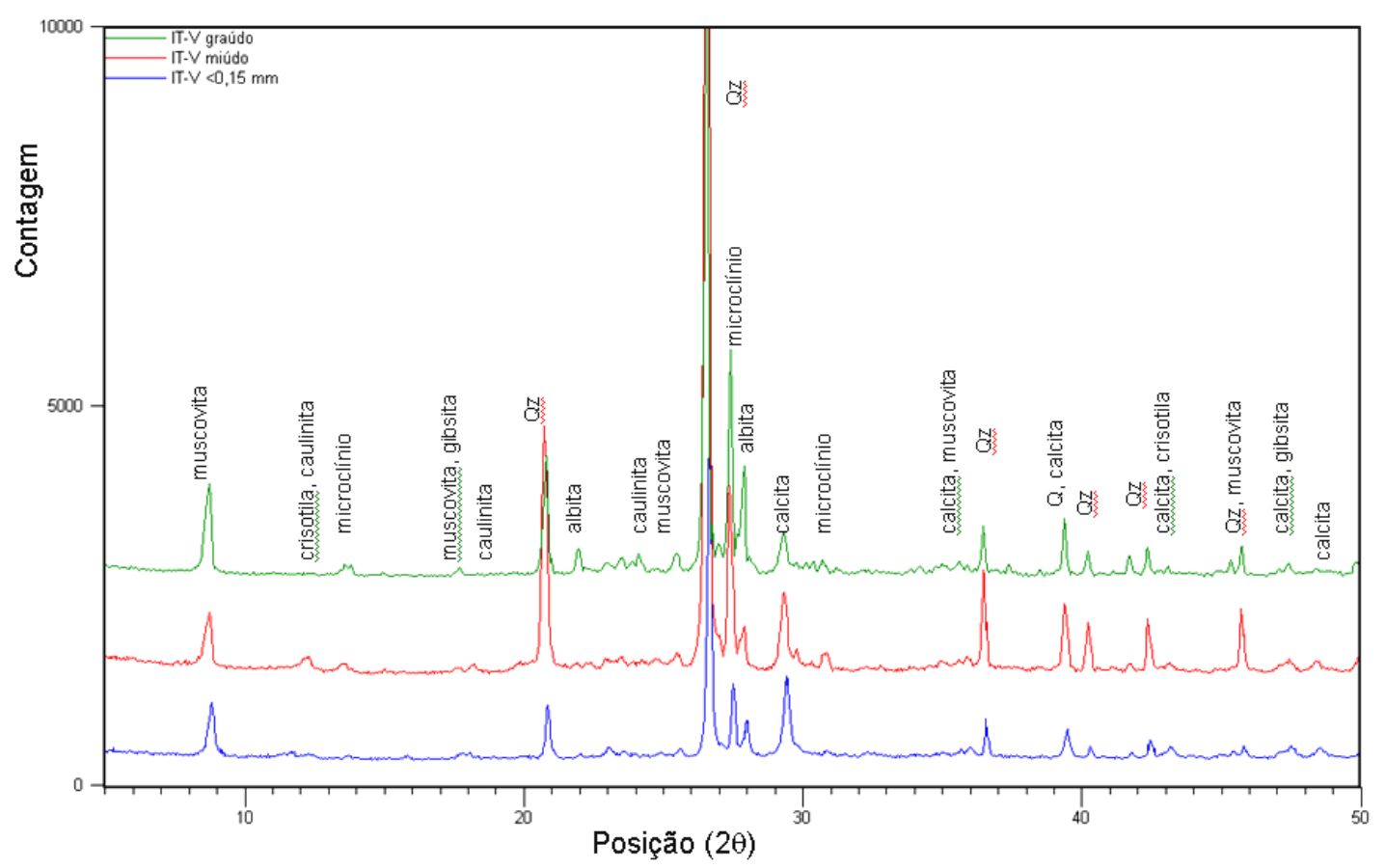

Figura 6.3 - Difratogramas comparativos referentes às frações granulométricas da amostra Itaquera Vermelho

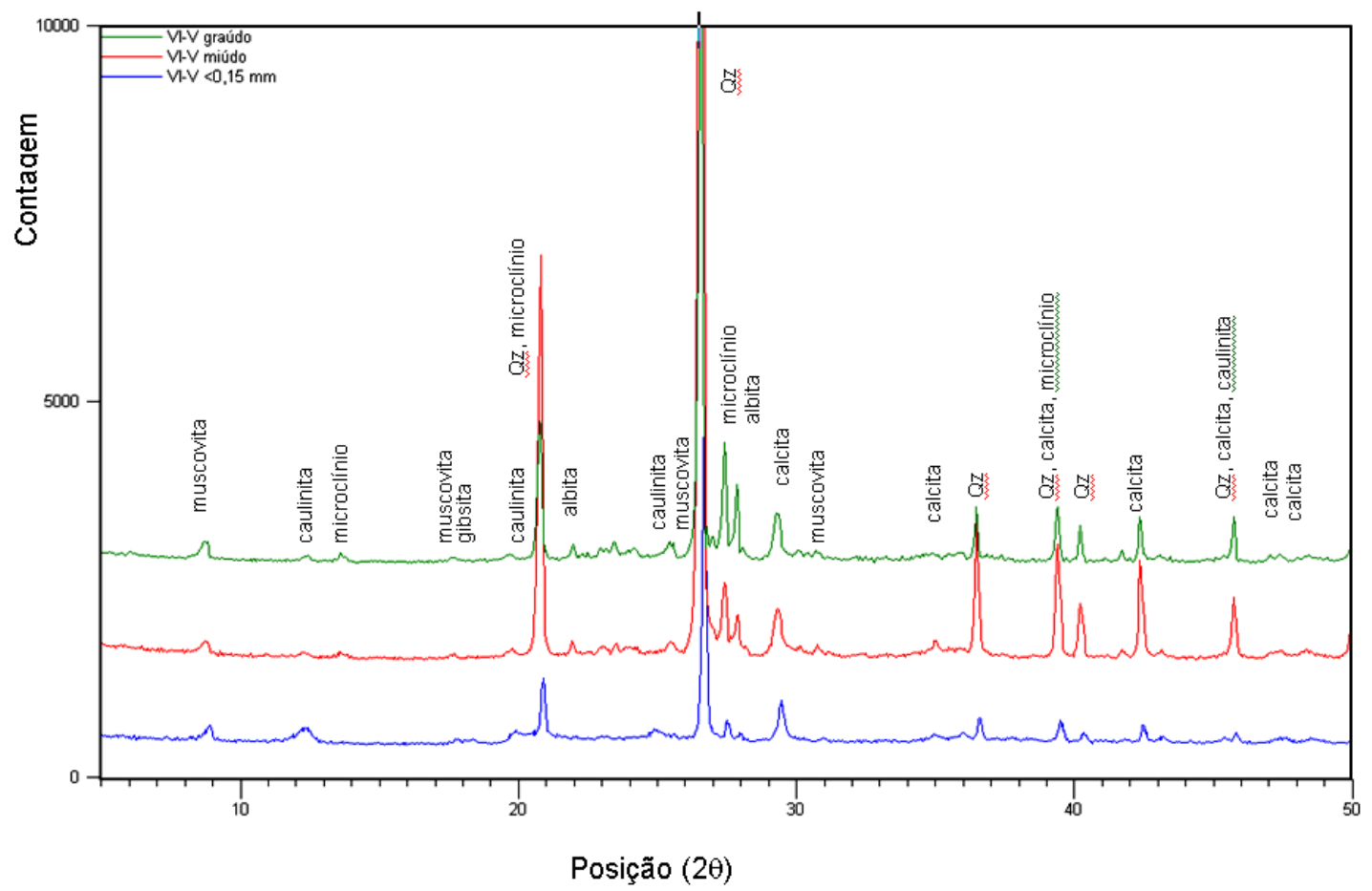

Figura 6.4 - Difratogramas comparativos referentes às frações granulométricas da amostra Vinhedo Vermelho 
Os resultados de análise mineralógica por difração de raios $\mathrm{X}$ dos produtos gerados nas separações em líquidos densos estão sumariados na Tabela 6.2 e apresentado comparativamente na Figura 6.5. Os difratogramas comparativos referentes aos produtos de separações densitárias de cada amostra são apresentados nas Figuras 6.6 a 6.8 .

Tabela 6.2 - Composição mineralógica dos produtos de separações densitárias para as frações graúda e miúda

\begin{tabular}{|c|c|c|c|c|c|c|c|c|c|c|c|}
\hline Am. & Produto & Fração & Feld. K & Albita & Qz & Mica & Argilm. & Gibsita & Crisot. & Calcita & Dol. \\
\hline \multirow{7}{*}{$\begin{array}{l}\stackrel{1}{上} \\
\stackrel{H}{H}\end{array}$} & $1,7<d<1,9$ & Graúdo & 18 & 8 & 22 & 17 & 3 & nd & nd & 27 & 5 \\
\hline & $1,9<d<2,2$ & Graúdo & 24 & 12 & 24 & 24 & 5 & nd & PP & 11 & nd \\
\hline & & Miúdo & 28 & 8 & 17 & 28 & 5 & nd & PP & 14 & nd \\
\hline & $2,2<d<2,5$ & Graúdo & 45 & 20 & 7 & 21 & 4 & nd & nd & 3 & nd \\
\hline & & Miúdo & 48 & 18 & 8 & 20 & 3 & nd & PP & 3 & nd \\
\hline & $d>2,5$ & Graúdo & 51 & 32 & 4 & 11 & 1 & nd & nd & 1 & nd \\
\hline & & Miúdo & 54 & 23 & 5 & 14 & nd & nd & PP & 1 & 3 \\
\hline \multirow{7}{*}{$\underset{H}{\overrightarrow{1}}$} & $1,7<d<1,9$ & Graúdo & 19 & 7 & 39 & 22 & 2 & nd & nd & 11 & nd \\
\hline & $1,9<d<2,2$ & Graúdo & 31 & 10 & 32 & 7 & 5 & nd & PP & 15 & nd \\
\hline & & Miúdo & 37 & 5 & 21 & 16 & 17 & nd & PP & 4 & nd \\
\hline & $2,2<d<2,5$ & Graúdo & 49 & 22 & 10 & 15 & 2 & nd & nd & 2 & nd \\
\hline & & Miúdo & 52 & 18 & 13 & 14 & 3 & nd & PP & 2 & nd \\
\hline & $d>2,5$ & Graúdo & 51 & 24 & 4 & 17 & 1 & nd & nd & 3 & nd \\
\hline & & Miúdo & 54 & 26 & 4 & 12 & 4 & nd & nd & nd & nd \\
\hline \multirow{7}{*}{$\begin{array}{l}\overrightarrow{1} \\
\end{array}$} & $1,7<d<1,9$ & Graúdo & 32 & 4 & 16 & 38 & 10 & nd & nd & nd & nd \\
\hline & $1,9<d<2,2$ & Graúdo & 28 & 9 & 16 & 33 & 5 & nd & nd & 9 & nd \\
\hline & & Miúdo & 36 & 5 & 18 & 31 & 4 & nd & nd & 7 & nd \\
\hline & $2,2<d<2,5$ & Graúdo & 45 & 18 & 11 & 20 & 2 & nd & nd & 4 & nd \\
\hline & & Miúdo & 48 & 20 & 7 & 19 & 1 & nd & PP & 5 & nd \\
\hline & $d>2,5$ & Graúdo & 52 & 23 & 3 & 19 & 2 & nd & nd & 1 & nd \\
\hline & & Miúdo & 55 & 30 & 4 & 6 & 4 & nd & nd & 1 & nd \\
\hline
\end{tabular}

Nota: Feldsp. K - feldspato potássico; Argilm. - argilominerais; pp - possível presença; nd - não detectado Proporções minerais estimadas a partir de difração de raios $X$, método RIR (valores semiquantiativos para fins comparativos) 


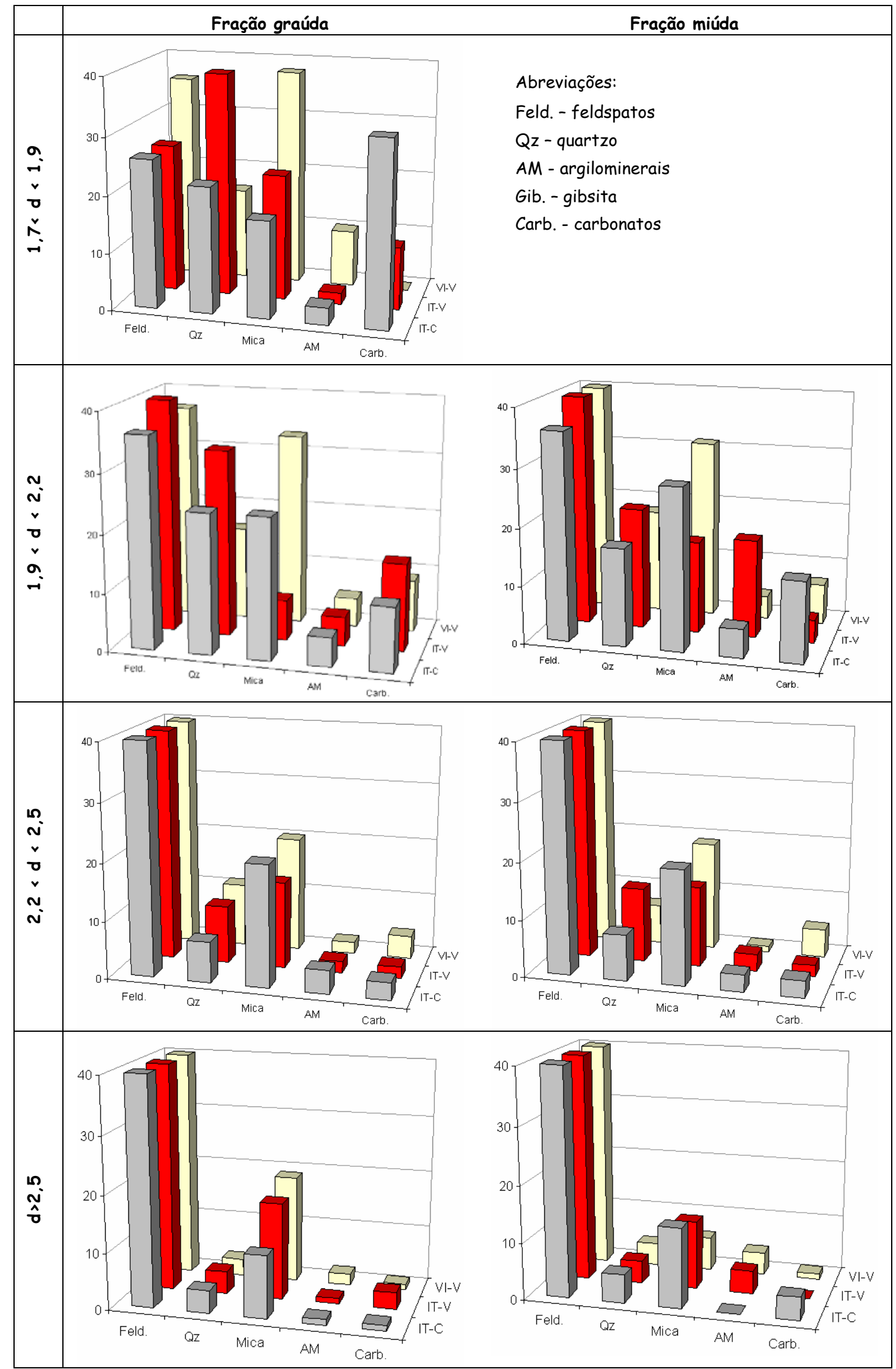

Figura 6.5 - Comparação entre composições mineralógicas dos produtos de separações densitárias 


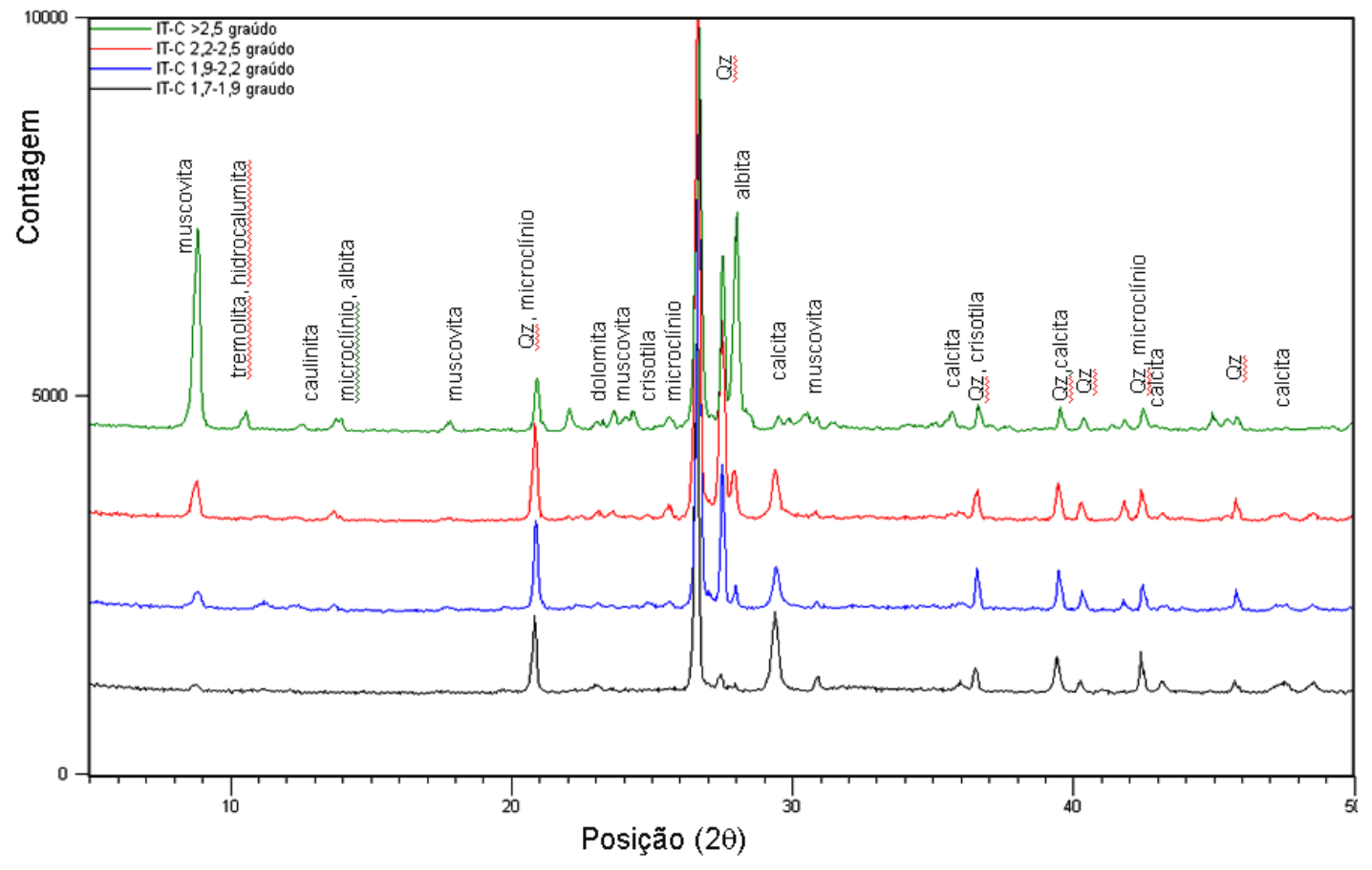

(a) - Fração graúda

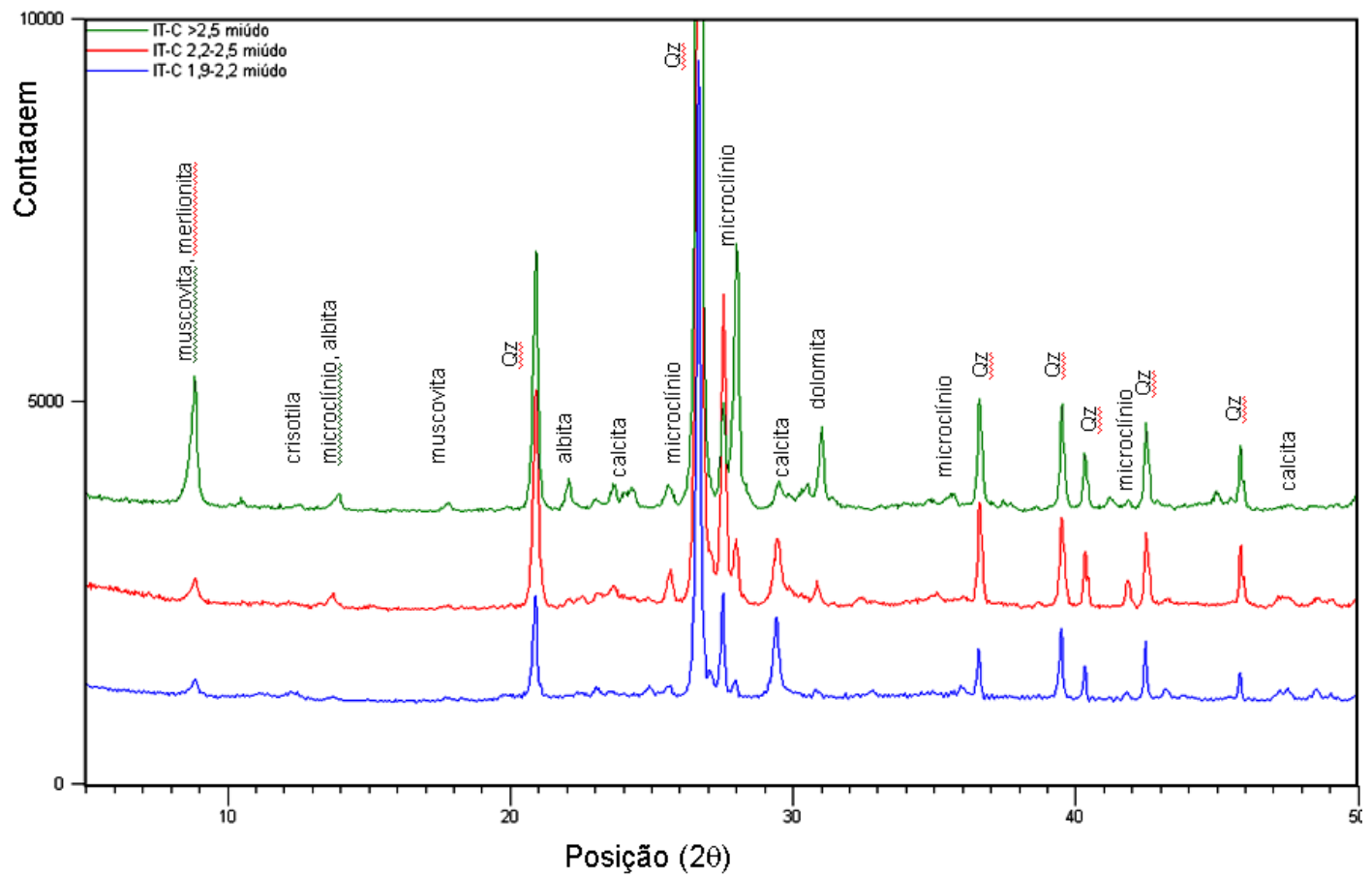

(b) - Fração miúda

Figura 6.6 - Difratogramas comparativos referentes aos produtos de separações densitárias da amostra Itaquera Cinza - fração graúda (a) e miúda (b) 


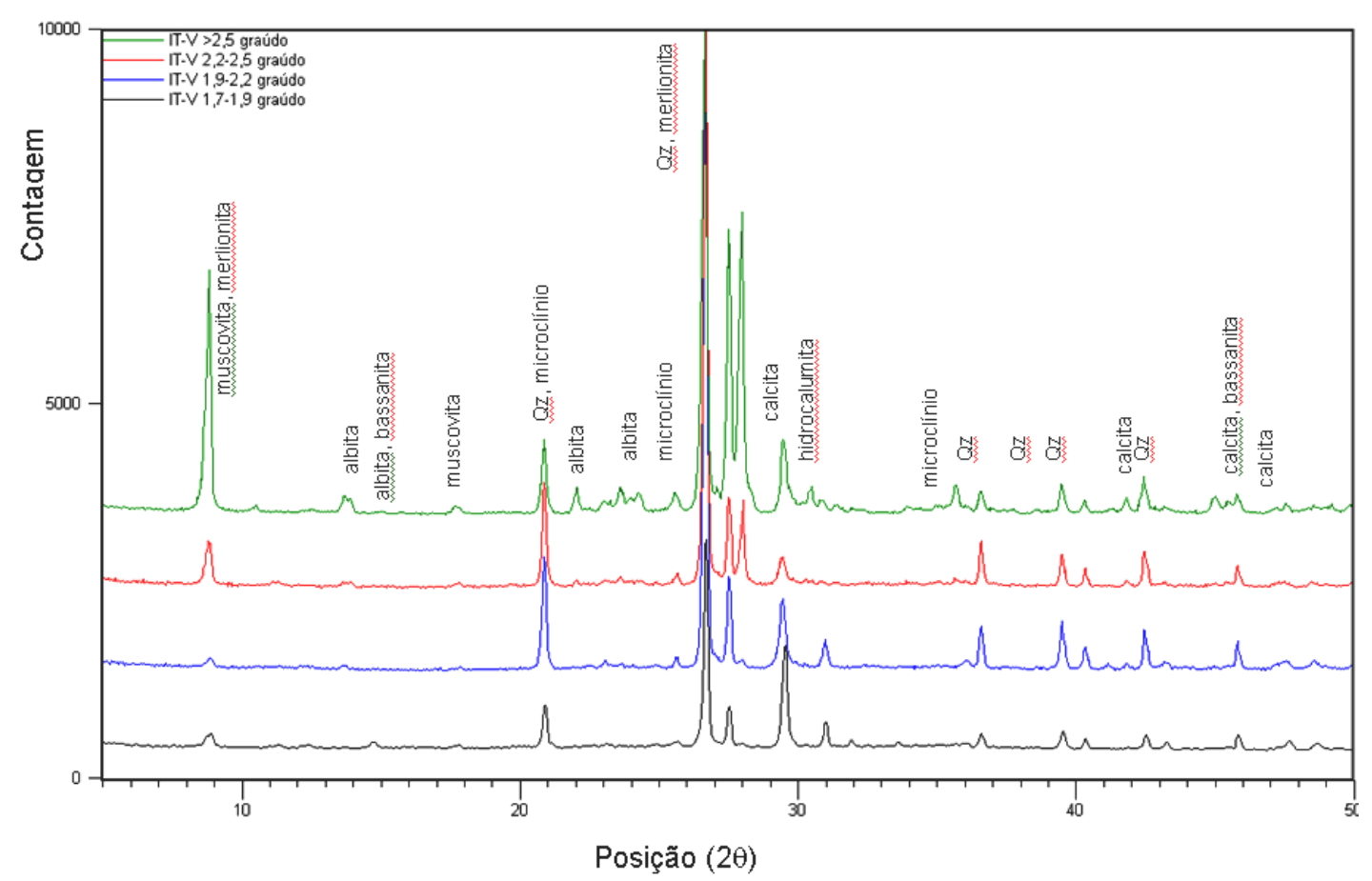

(a) - Fração graúda

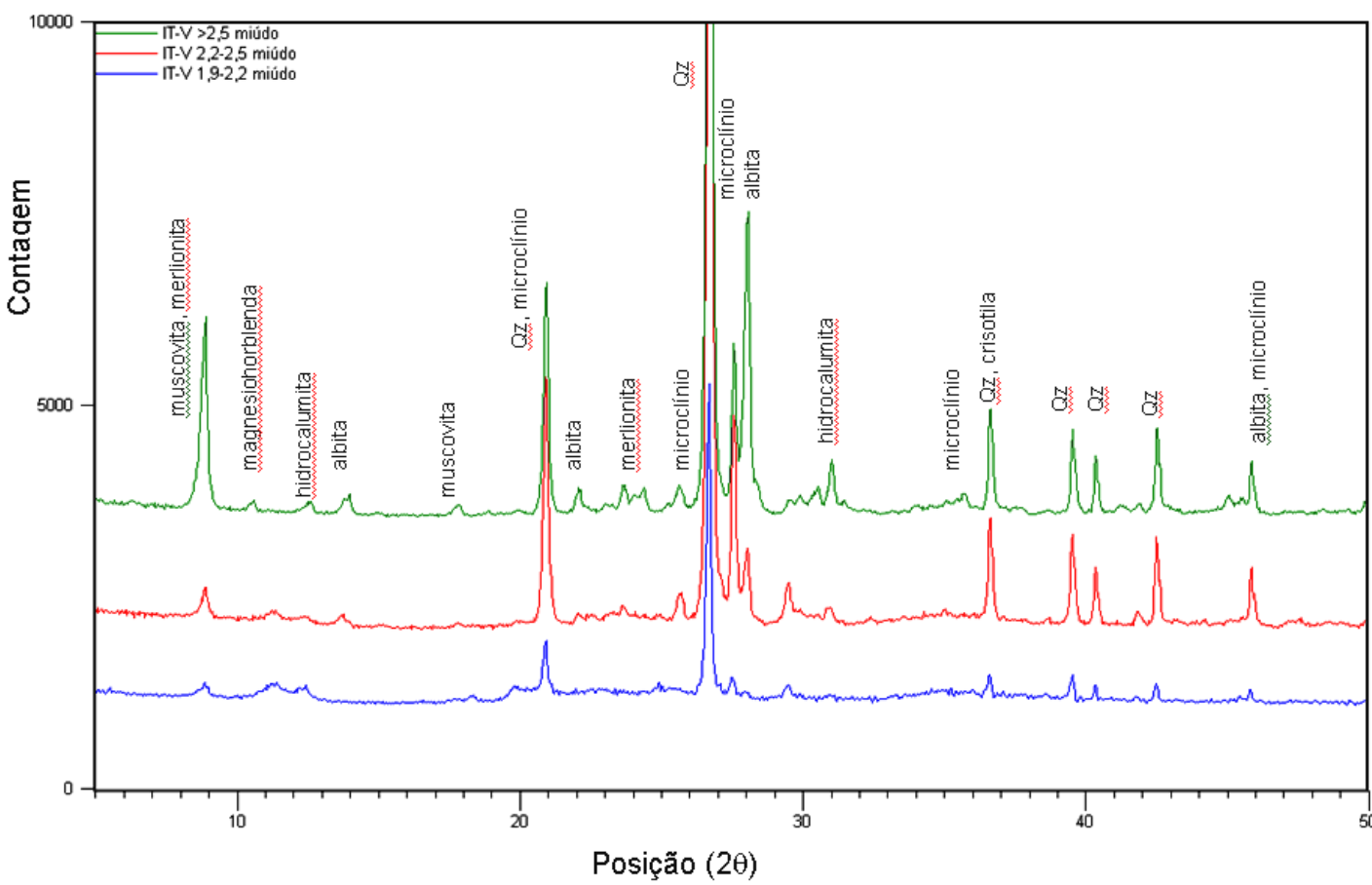

(b) - Fração miúda

Figura 6.7 - Difratogramas comparativos referentes aos produtos de separações densitárias da amostra Itaquera Vermelho - fração graúda (a) e miúda (b) 


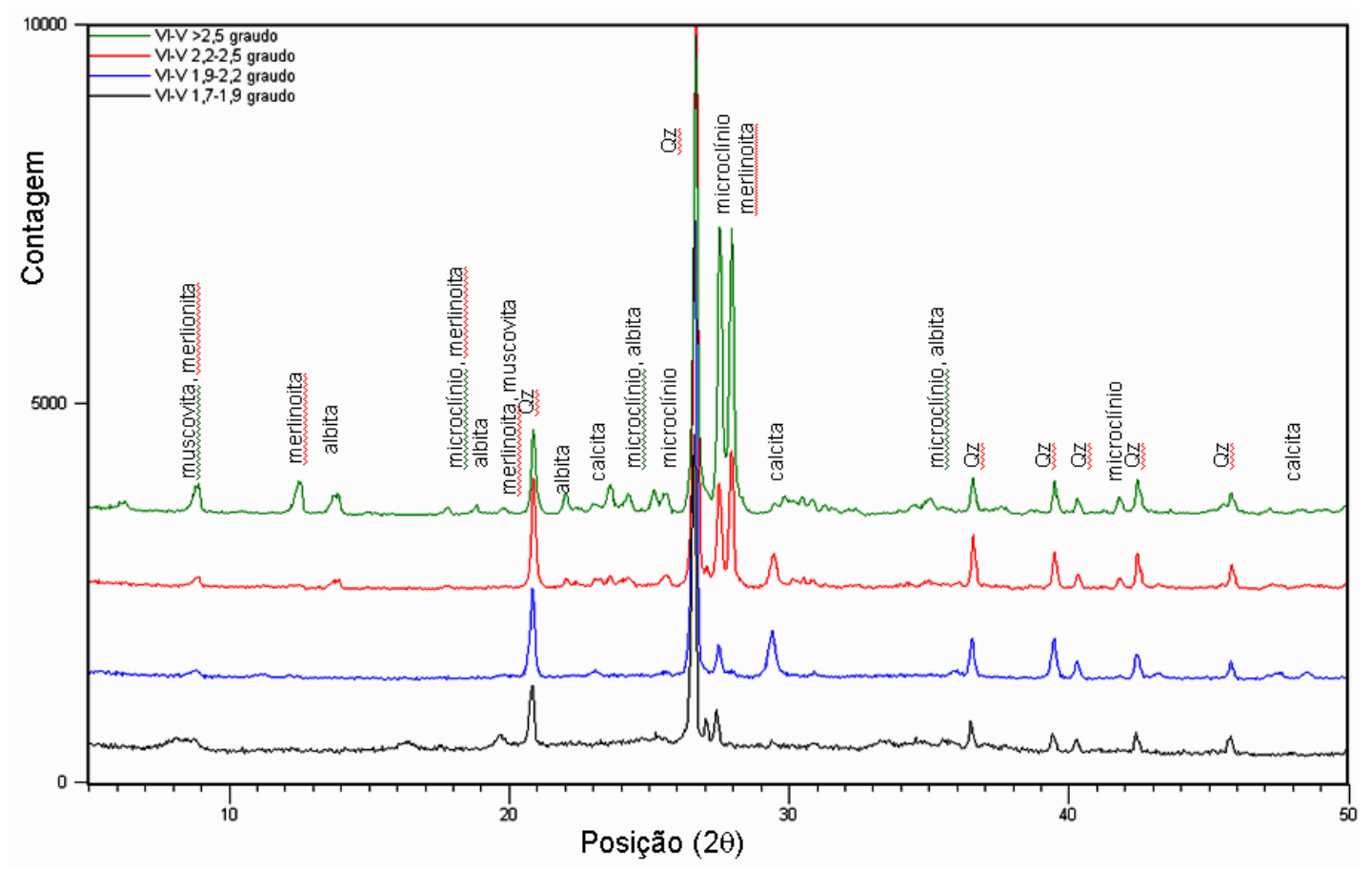

(a) - Fração graúda

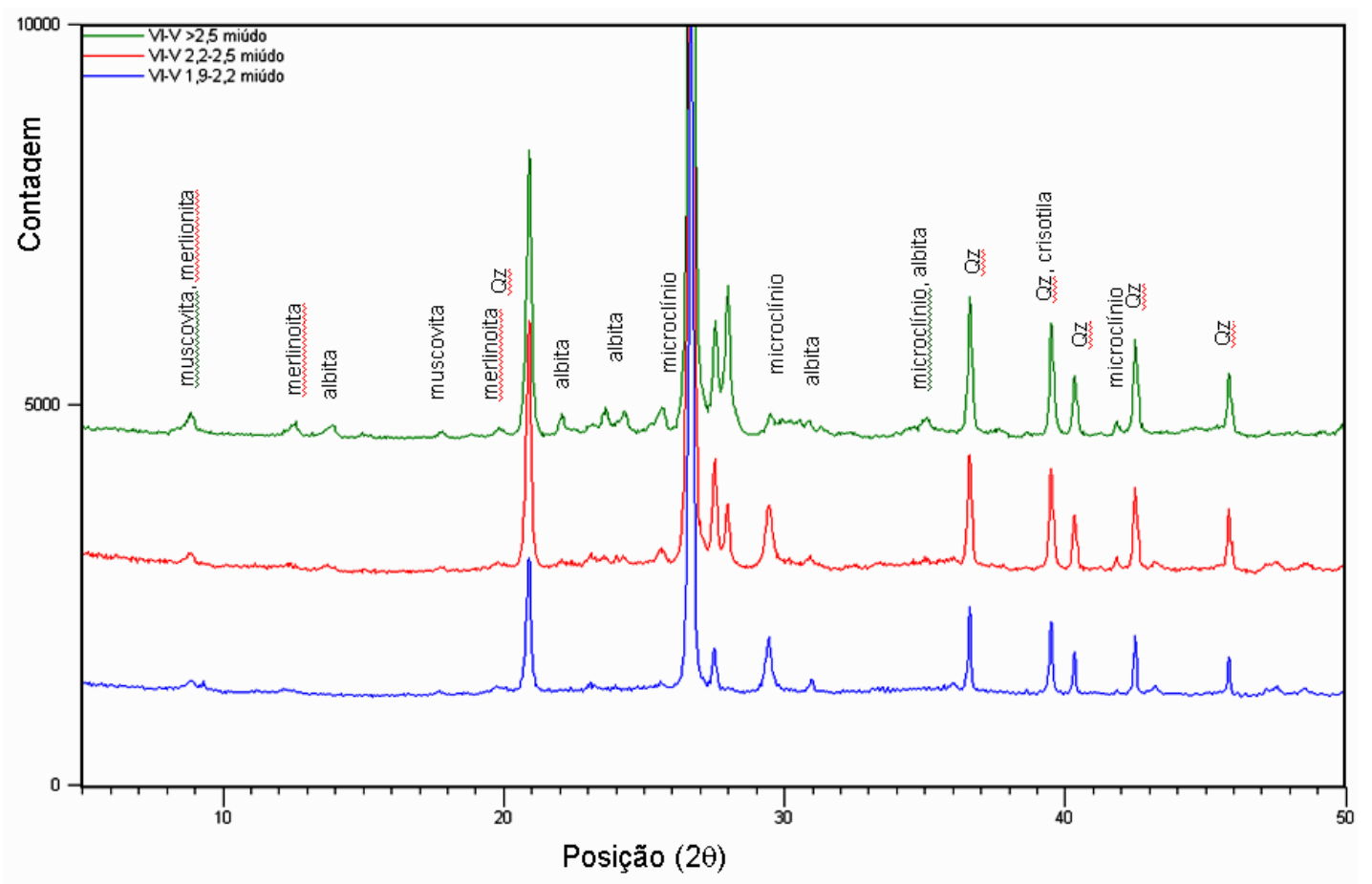

(b) - Fração miúda

Figura 6.8 - Difratogramas comparativos referentes aos produtos de separações densitárias da amostra Vinhedo Vermelho - fração graúda (a) e miúda (b) 
As principais fases identificadas foram a) tectosilicatos provenientes de rochas naturais, b) carbonatos e c) filossilicatos (muscovita/biotita/flogopita, merlionita e caulinita). A presença de cerâmica branca ou de adições do cimento, tais como cinza volante, é baixa, visto que não foi identificada mulita nas difrações.

O produto de massa específica aparente menor que $2,2 \mathrm{~g} / \mathrm{cm}^{3}$ se caracteriza pela presença de carbonatos (essencialmente calcita), mica e quartzo. Silicatos hidratados das fases cimentícias não foram detectados por difração, mas estão presentes conforme verificado por Ângulo (2005); estes em conjunto com os argilominerais são os principais responsáveis pelos elevados valores de perda ao fogo.

Para os produtos com massa específica aparente superior a $2,2 \mathrm{~g} / \mathrm{cm}^{3}$ verifica-se um significativo aumento nas proporções de feldspatos (microclínio e albita) e redução de mica, quartzo, argilominerais e carbonatos, indicando presença de agregados naturais (pedra britada). Somado a isso as análises de perda ao fogo e microestruturais confirmam a redução nas proporções de argilominerais e aglomerantes e presença de fragmentos líticos. 


\subsection{MICROSCOPIA ÓPTICA}

\subsubsection{Fração graúda}

Os produtos de densidade inferior a $1,7 \mathrm{~g} / \mathrm{cm}^{3}$ apresentam um teor reduzido de partículas minerais, grande parte deste é composto por elevadas quantidades de material não-mineral; sendo assim, o produto não traz interesse para a reciclagem e, portanto, não foi caracterizado do ponto de vista microestrutural.

A Figura 6.9 ilustra os contaminantes presentes ao lado de pequenas quantidades de material mineral.

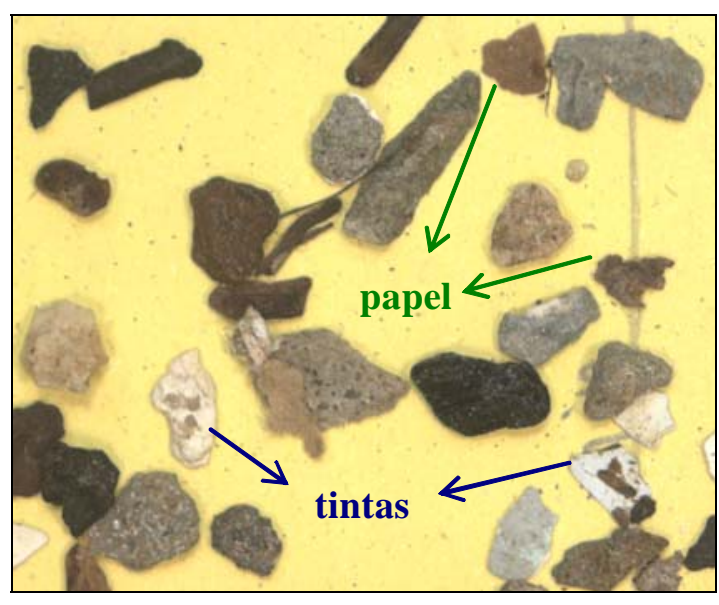

(a)

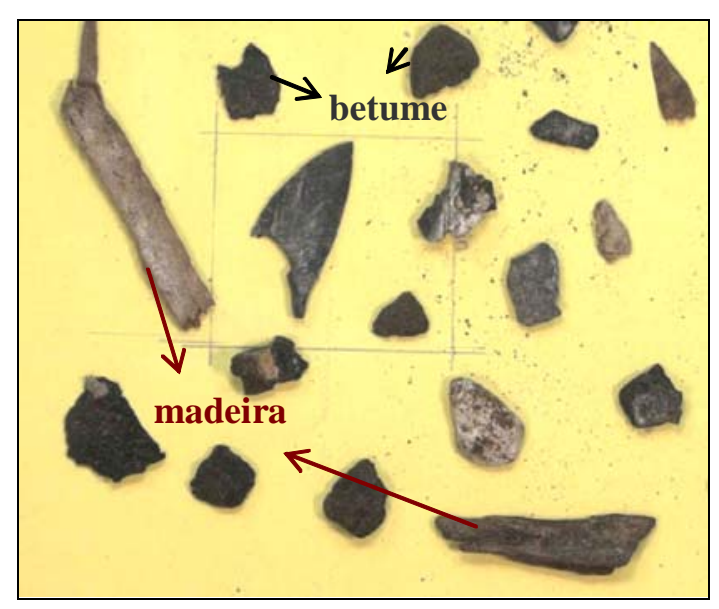

(b)

Figura 6.9 - Partículas não minerais presentes em (a) IT-V d<1,7 -12,7+9,5 mm e (b) VI-V $4,8+2,4 \mathrm{~mm} \mathrm{~d}<1,7$ (aumento de $5 \mathrm{x}$ )

Os produtos de densidade da fração graúda dos RCD reciclados foi observada em seções polidas sob incidência de luz nas faixas de comprimento de onda do visível e ultravioleta. Sob luz ultravioleta a presença de aglomerantes é evidenciada através da fluorescência em tons claros.

\subsubsection{Produtos de densidade entre 1,9 e $2,2 \mathrm{~g} / \mathrm{cm}^{3}$}

A Figura 6.10 ilustra comparativamente seções polidas dos produtos contidos no intervalo de densidade $1,9-2,2 \mathrm{~g} / \mathrm{cm}^{3}$ para as amostras IT-C, IT-V e VI-V, fração graúda.

As fotografias da seção com luz incidente nas faixas de comprimento de onda do visível e ultravioleta são apresentadas na Figura 6.11. 

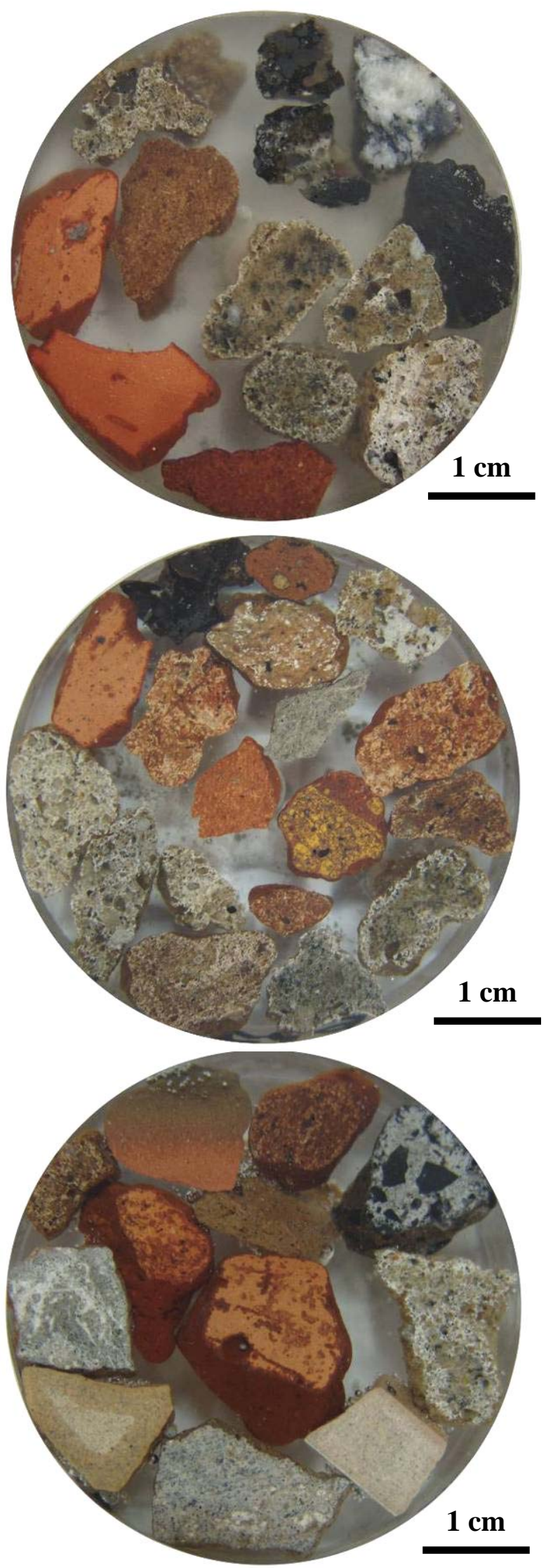

Figura 6.10 - Seções polidas dos produtos do intervalo de densidade entre 1,9 e 2,2 g/cm
Fração -9,5+4,8 mm densidade $1,9-2,2 \mathrm{~g} / \mathrm{cm}^{3}$

IT-V

Fração $-9,5+4,8 \mathrm{~mm}$ densidade $1,9-2,2 \mathrm{~g} / \mathrm{cm}^{3}$

VI-V

Fração -12,5+9,5 mm densidade 1,9-2,2 $\mathrm{g} / \mathrm{cm}^{3}$ 


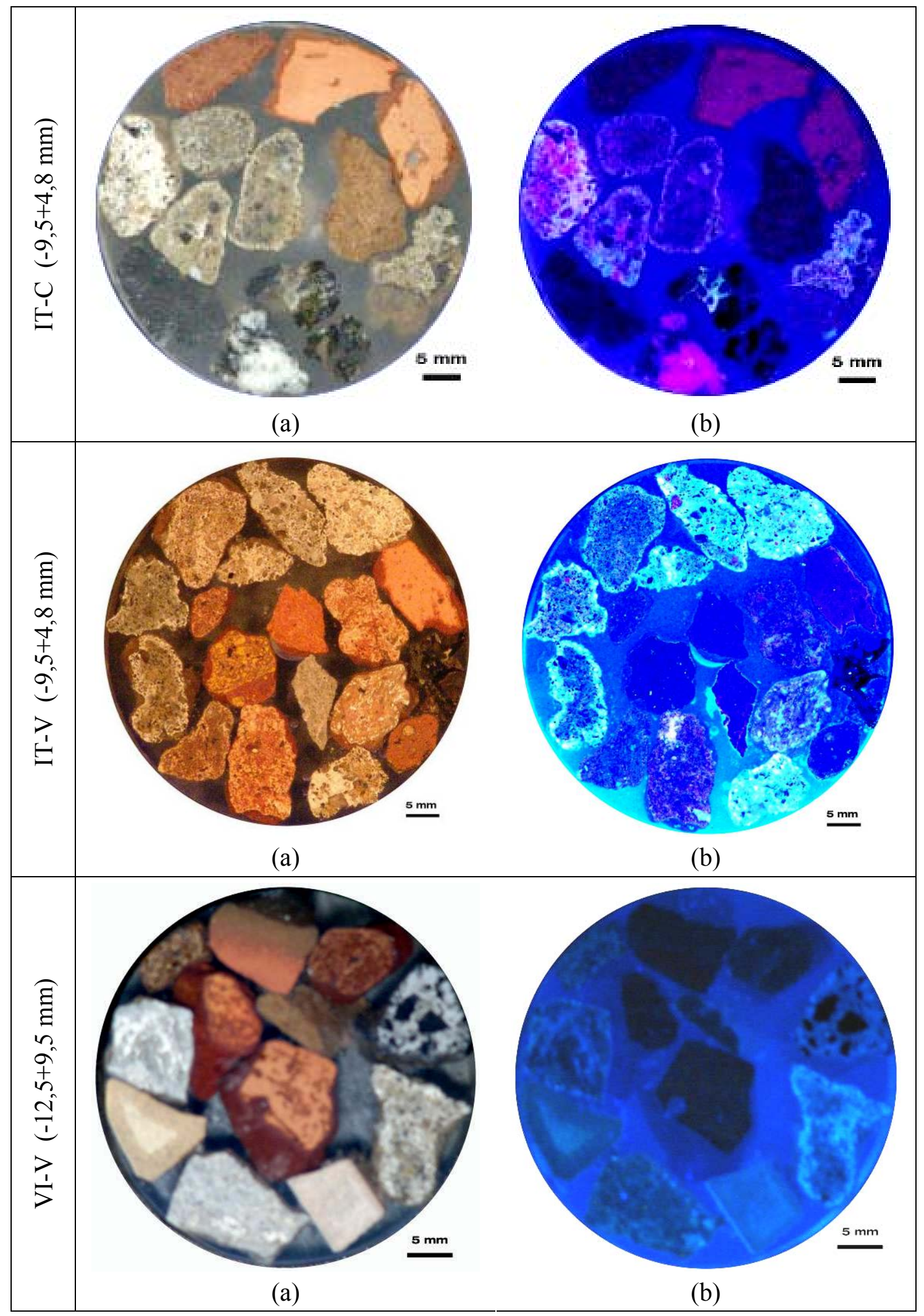

Figura 6.11 - Seções polidas dos produtos do intervalo de densidade entre 1,9-2,2 g/cm $\mathrm{sob}$ luz incidente nas faixas de comprimento de onda do visível (a) e ultravioleta (b) 
Os produtos de densidade inferior a $2,2 \mathrm{~g} / \mathrm{cm}^{3}$ apresentam uma grande quantidade de partículas envoltas por elevados teores de aglomerantes, caracterizados pela luminescência sob luz ultravioleta. Não são verificados aglomerantes nas partículas de material cerâmico, entretanto as de origem cimentícia podem estar tomadas, quase na totalidade, por pasta de cimento endurecida e cal.

O material de IT-C se caracteriza por apresentar pouca quantidade de aglomerantes nas partículas minerais, usualmente concentrados nas bordas; IT-V por sua vez apresenta elevada quantidade de partículas cerâmicas raramente cimentadas e uma parcela expressiva de material cimentício de elevada porosidade com grandes quantidades de aglomerantes; VI-V, por ter composição predominante de partículas cerâmicas, apresenta um baixo teor de pasta de cimento endurecida e cal.

\subsubsection{Produtos de densidade entre 2,2 e $2,5 \mathrm{~g} / \mathrm{cm}^{3}$}

A Figura 6.12 ilustra comparativamente seções polidas dos produtos contidos no intervalo de densidade $2,2-2,5 \mathrm{~g} / \mathrm{cm}^{3}$ para as amostras IT-C, IT-V e VI-V, fração graúda. As fotografias da seção com luz incidente nas faixas de comprimento de onda do visível e ultravioleta são apresentadas na Figura 6.13.

Os produtos situados entre as densidades 2,2 e $2,5 \mathrm{~g} / \mathrm{cm}^{3}$ são constituídos basicamente por partículas de minerais com pequenas quantidades de aglomerantes na amostra IT-C; já para IT-V e VI-V é elevado o número de partículas cimentícias com alto teor de pasta.

\subsubsection{Produtos de densidade superior a $2,5 \mathrm{~g} / \mathrm{cm} 3$}

A Figura 6.14 ilustra comparativamente seções polidas dos produtos contidos no intervalo de densidade superior a $2,5 \mathrm{~g} / \mathrm{cm}^{3}$ para as amostras IT-C, IT-V e VI-V, fração graúda. As fotografias da seção com luz incidente nas faixas de comprimento de onda do visível e ultravioleta são apresentadas na Figura 6.15.

Os produtos de densidade superior a $2,5 \mathrm{~g} / \mathrm{cm}^{3}$ são essencialmente constituídos por partículas de rochas liberadas, por vezes associadas a pequenas quantidades de pasta de cimento endurecida e/ou cal aderidas à superfície dos grãos. 

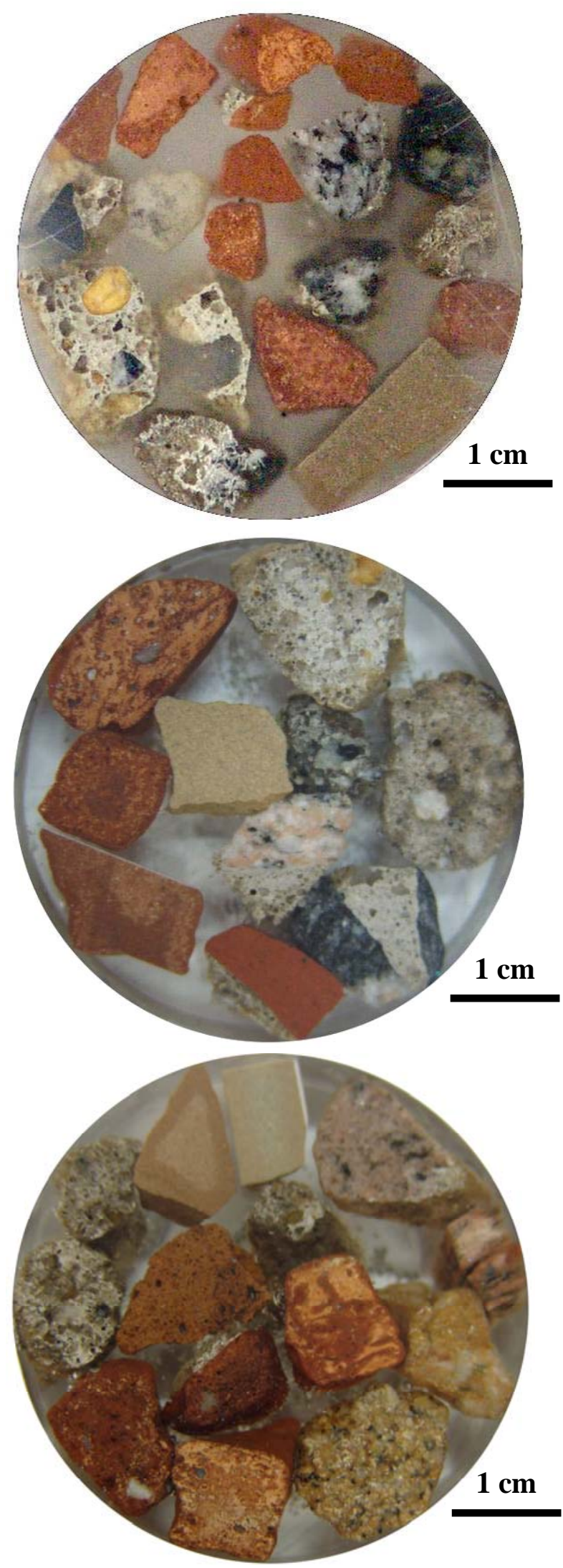

Figura 6.12 - Seções polidas dos produtos do intervalo de densidade entre 2,2-2,5 g/cm ${ }^{3}$
Fração -9,5+4,8 mm densidade $2,2-2,5 \mathrm{~g} / \mathrm{cm}^{3}$

IT-V

Fração 12,5+9,5 mm densidade $2,2-2,5 \mathrm{~g} / \mathrm{cm}^{3}$

\section{VI-V}

Fração 12,5+9,5 mm densidade $2,2-2,5 \mathrm{~g} / \mathrm{cm}^{3}$ 


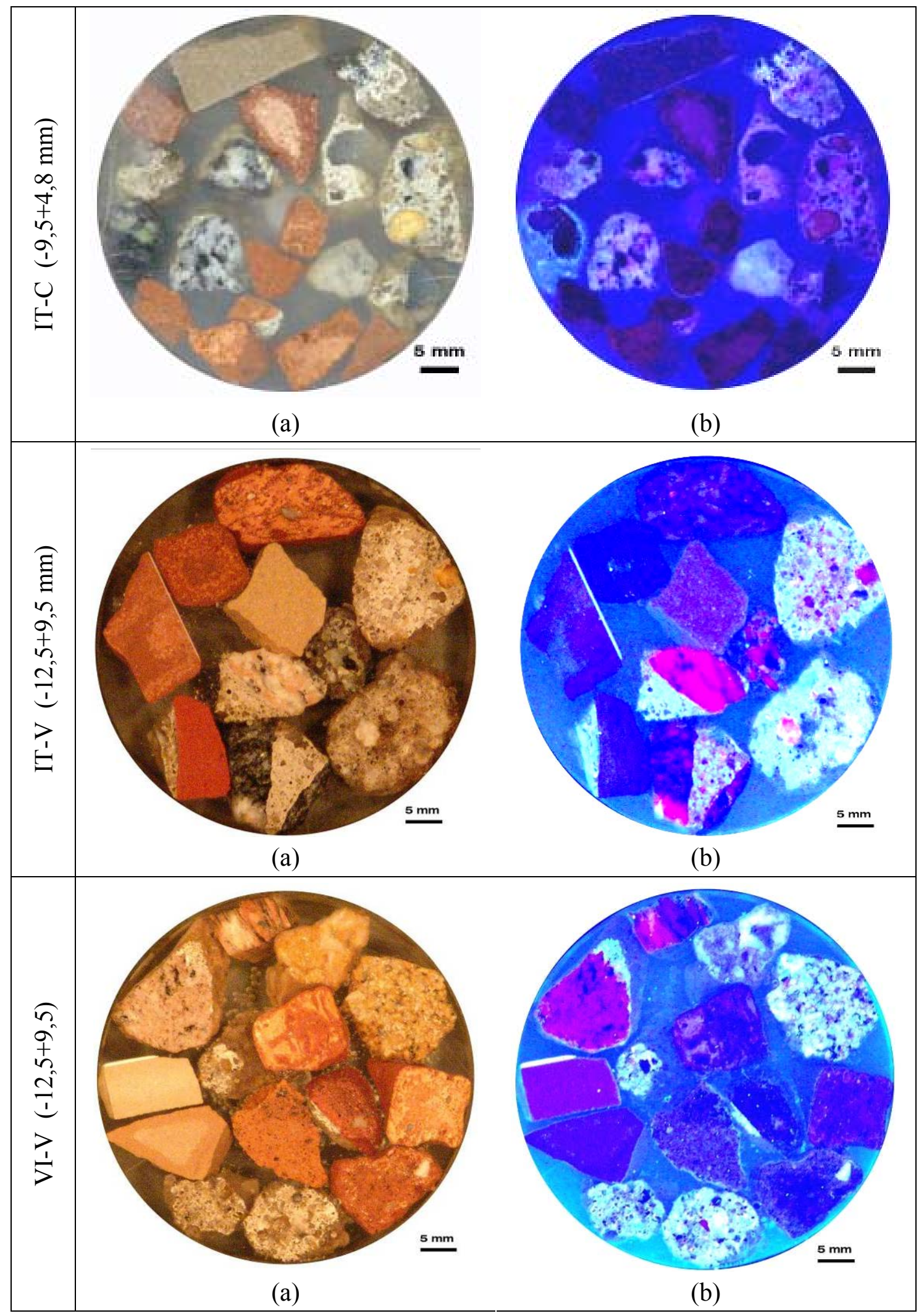

Figura 6.13 - Seções polidas dos produtos do intervalo de densidade entre $2,2-2,5 \mathrm{~g} / \mathrm{cm}^{3} \mathrm{sob}$ luz incidente nas faixas de comprimento de onda do visível (a) e ultravioleta (b) 


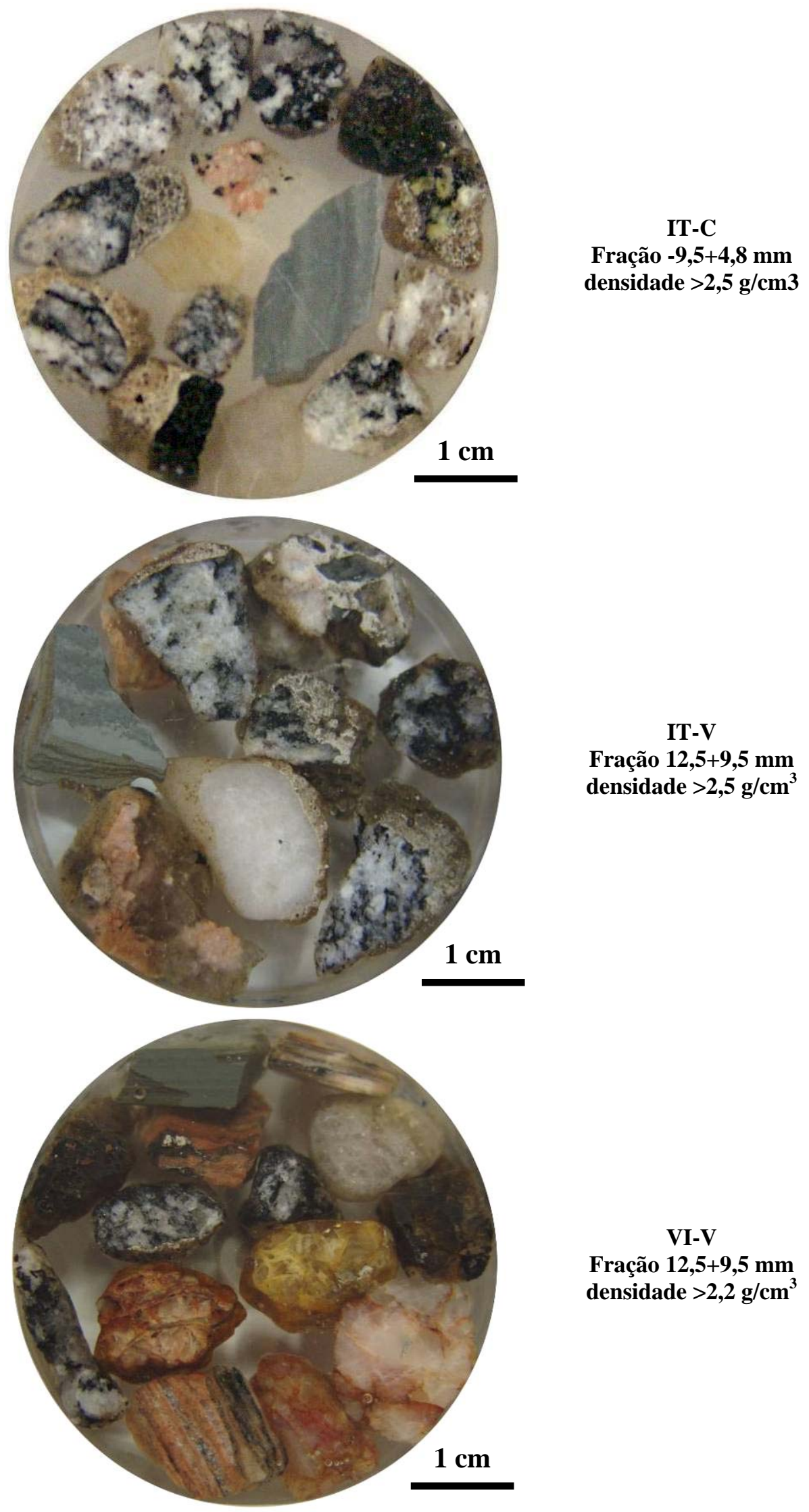

Figura 6.14 - Seções polidas dos produtos do intervalo de densidade entre $2,2-2,5 \mathrm{~g} / \mathrm{cm}^{3}$ 


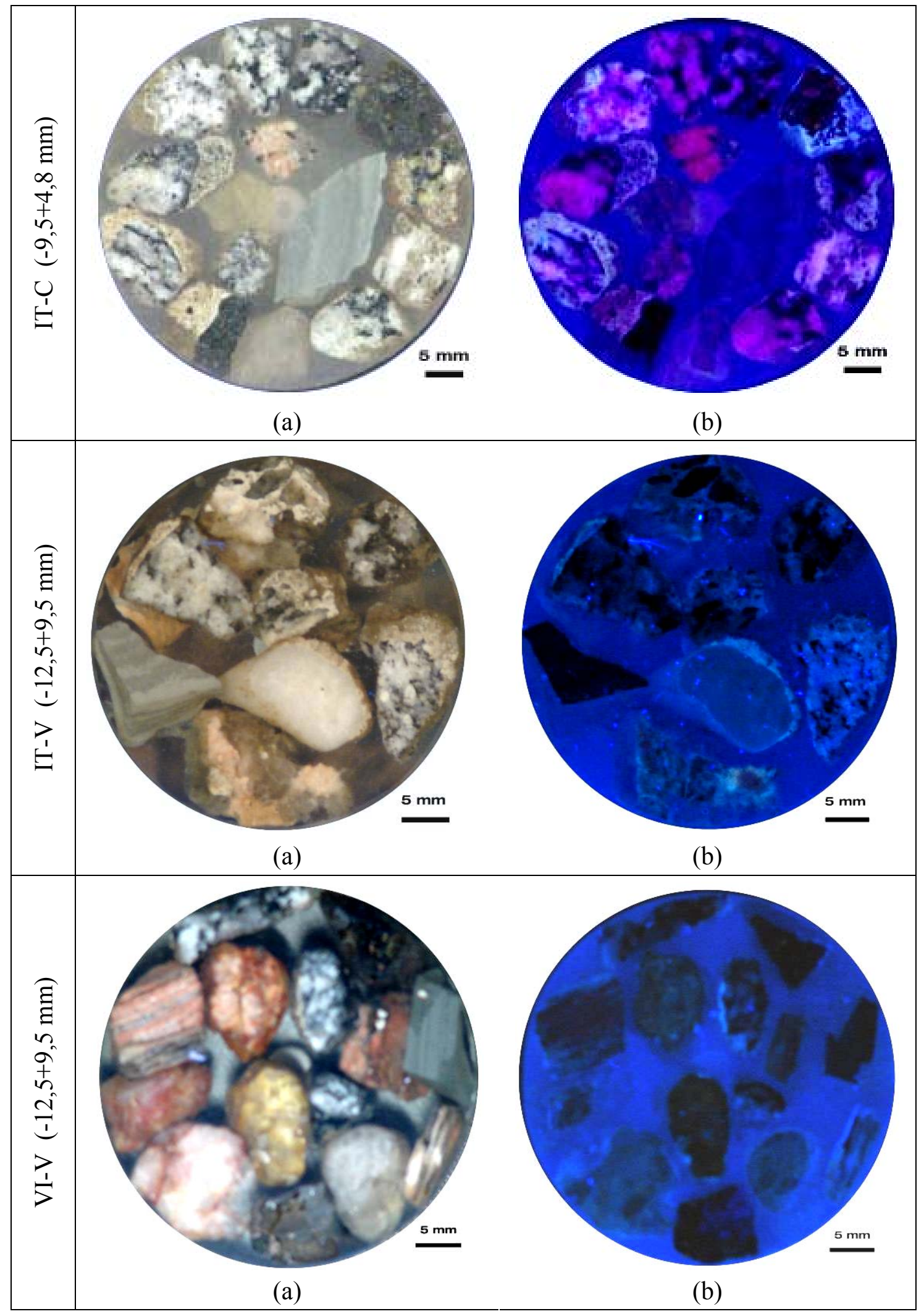

Figura 6.15 - Seções polidas dos produtos do intervalo de densidade superior a $2,5 \mathrm{~g} / \mathrm{cm}^{3} \mathrm{sob}$ luz incidente nas faixas de comprimento de onda do visível (a) e ultravioleta (b) 


\subsubsection{Fração miúda}

A caracterização microestrutural da fração miúda dos RCD reciclados foi realizada através de observações em microscópio estereoscópico e óptico de polarização por luz transmitida em seções delgadas polidas.

\subsubsection{Produtos de densidade entre 1,9 e $2,2 \mathrm{~g} / \mathrm{cm}^{3}$}

As seções delgadas polidas dos produtos de densidade entre 1,9 e 2,2 $\mathrm{g} / \mathrm{cm}^{3}$ para as três amostras estudadas são apresentadas a seguir, respectivamente:

- $\quad$ IT-C, Figuras 6.16 e 6.17

- $\quad$ IT-V, Figuras 6.16 e 6.18

- VI-V, Figuras 6.16 e 6.19

Verifica-se que as partículas de minerais (em cores claras - esbranquiçada, ou em cores vivas de azul) encontram-se envoltas por grande quantidade de aglomerantes (pasta de cimento e cal), caracterizada pelas porções escuras da fotografia, formando uma espécie de conglomerado em que, muitas vezes, o aglomerante perfaz mais de $50 \%$ em área. O produto de Vinhedo possui características muito semelhantes, porém diferencia-se de Itaquera a medida que apresenta elevada quantidade de partículas cerâmicas, estas que, independente da origem do RCD reciclado, encontram-se livres de pasta. 


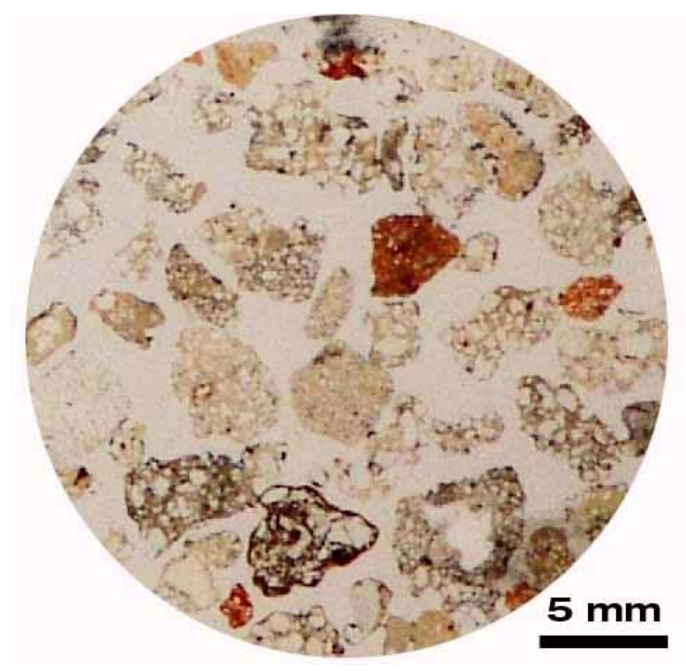

IT-C $(-4,8+1,2 \mathrm{~mm})$

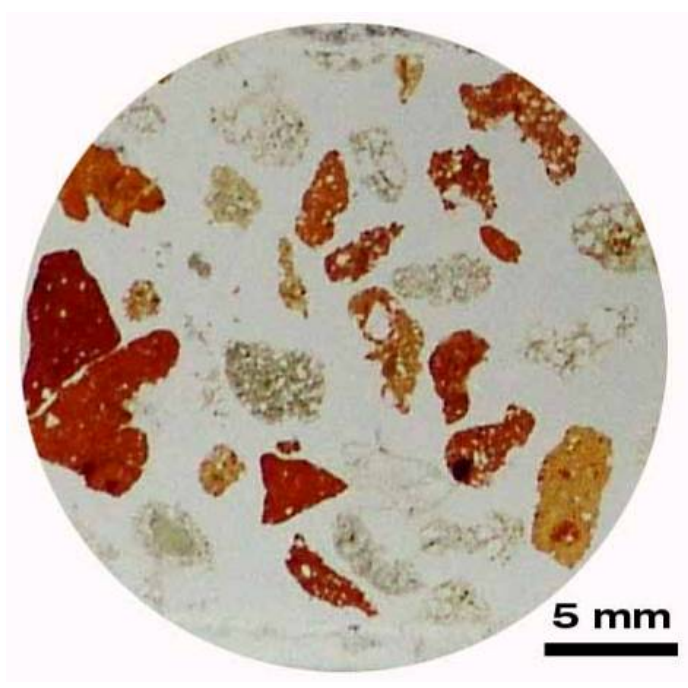

(a)

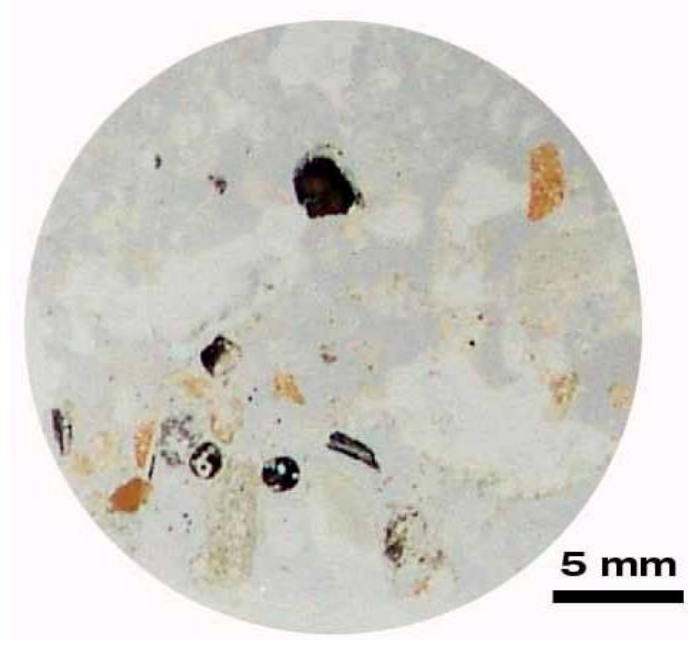

IT-V (-4,8+1,2 mm)

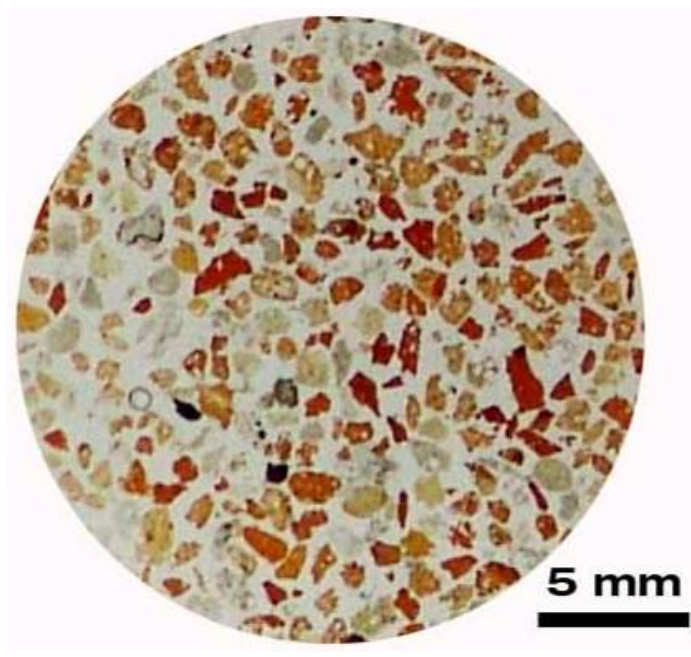

(b)

VI-V (a) -4,8+2,4 mm e (b) -1,2+0,3 mm

Figura 6.16 - Fotografias das seções delgadas polidas das frações miúdas dos produtos de densidade entre 1,9-2,2 $\mathrm{g} / \mathrm{cm}^{3}$ de IT-C, IT-V e VI-V 
Itaquera cinza - 1,9-2,2 $\mathrm{g} / \mathrm{cm}^{3}$
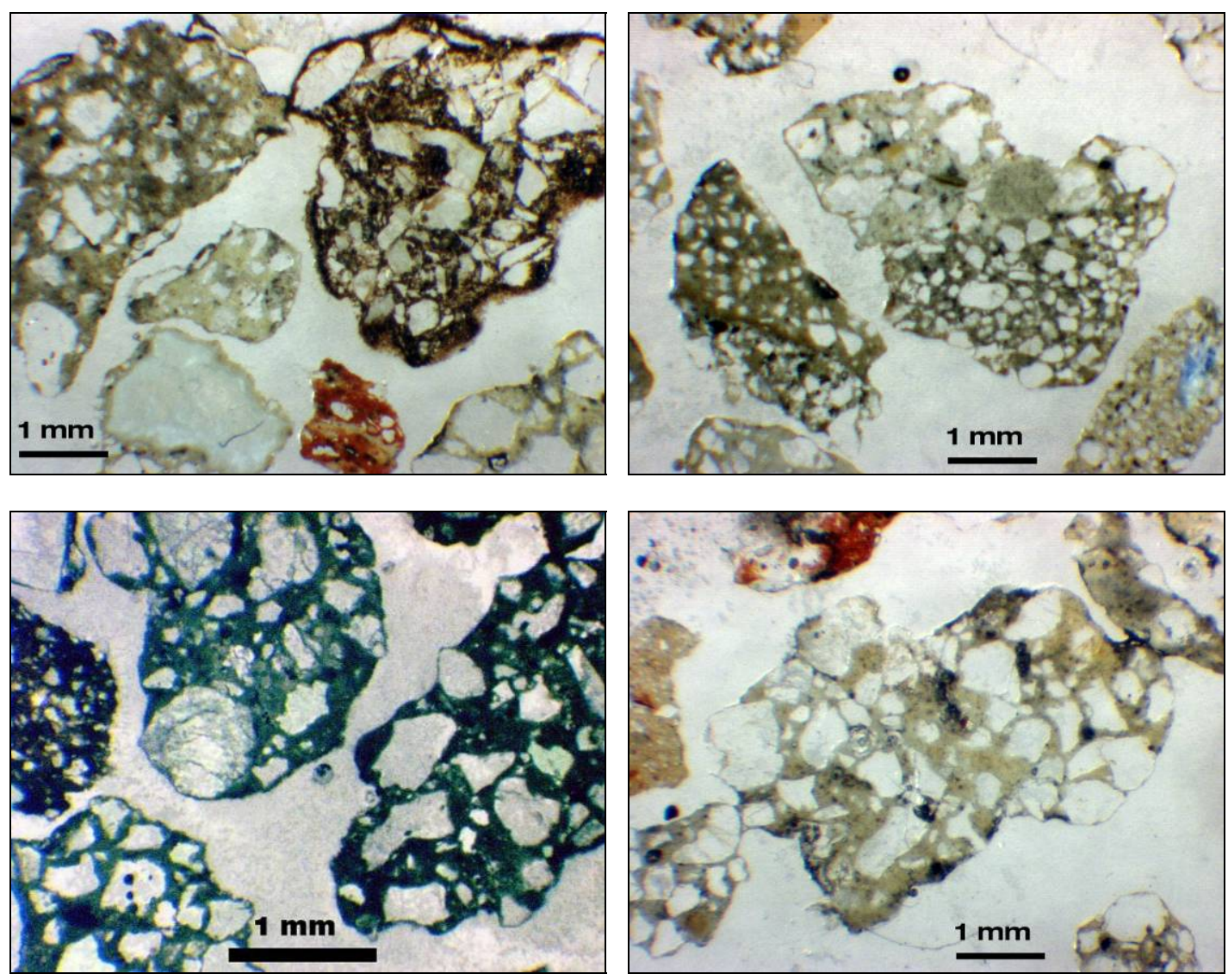

Fotografias em estereomicroscópio $(-4,8+1,2 \mathrm{~mm})$
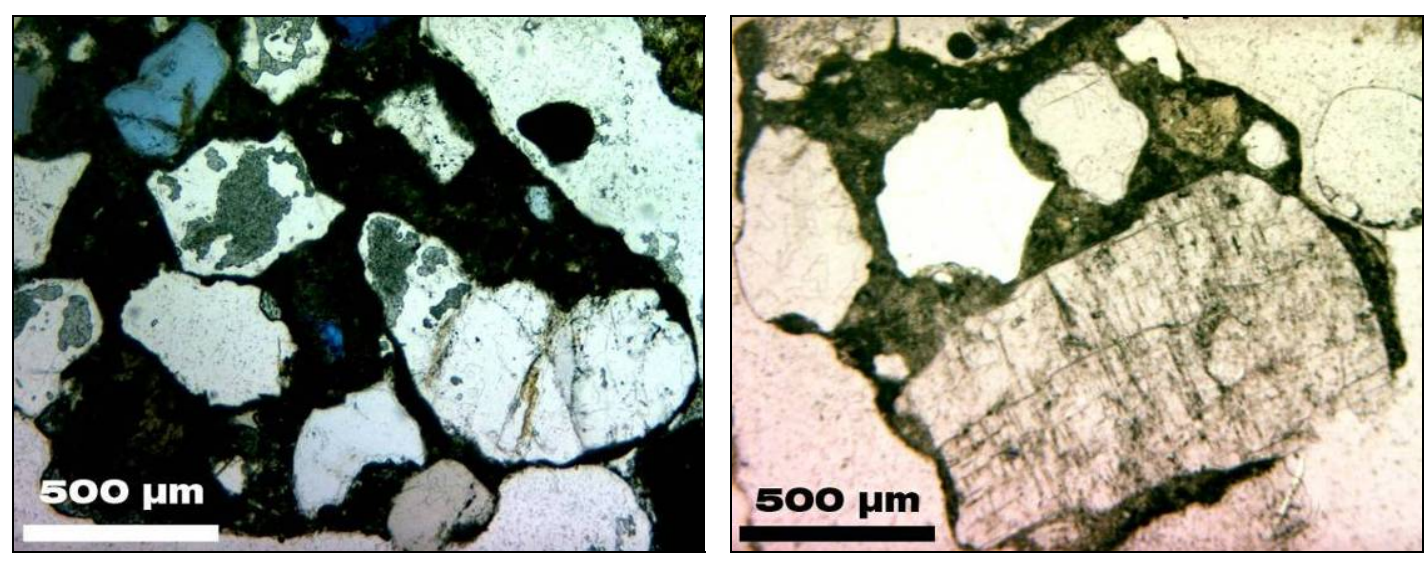

Fotografias em microscópio de polarização por luz transmitida $(-4,8+1,2$ mm)

Figura 6.17 - Microfotografias da fração miúda dos produtos de densidade $1,9-2,2 \mathrm{~g} / \mathrm{cm}^{3}$ de IT-C 
Itaquera vermelho - $1,9-2,2 \mathrm{~g} / \mathrm{cm}^{3}$
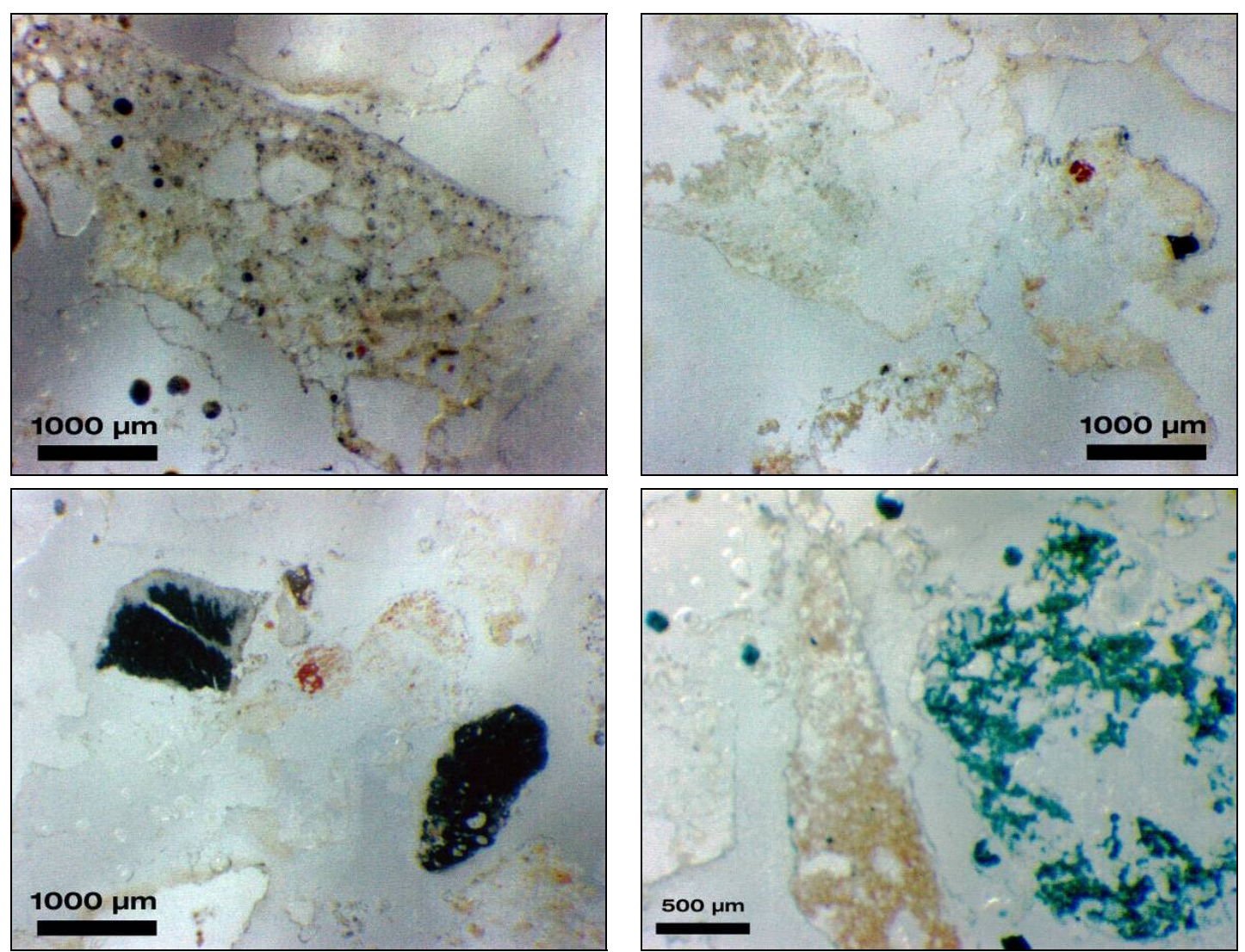

Fotografias em estereomicroscópio (-4,8+1,2 mm)
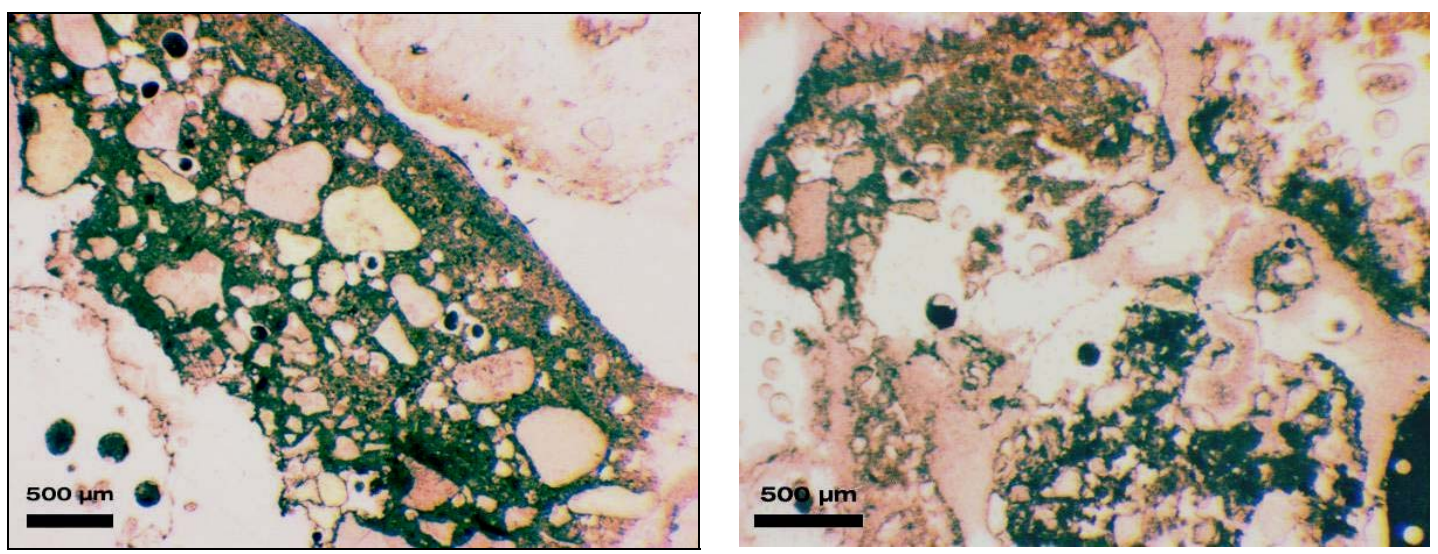

Fotografias em microscópio de polarização por luz transmitida $(-4,8+1,2 \mathrm{~mm})$

Figura 6.18 - Microfotografias da fração miúda dos produtos de densidade $1,9-2,2 \mathrm{~g} / \mathrm{cm}^{3} \mathrm{de}$ IT-V 
Vinhedo vermelho - 1,9-2,2 $\mathrm{g} / \mathrm{cm}^{3}$
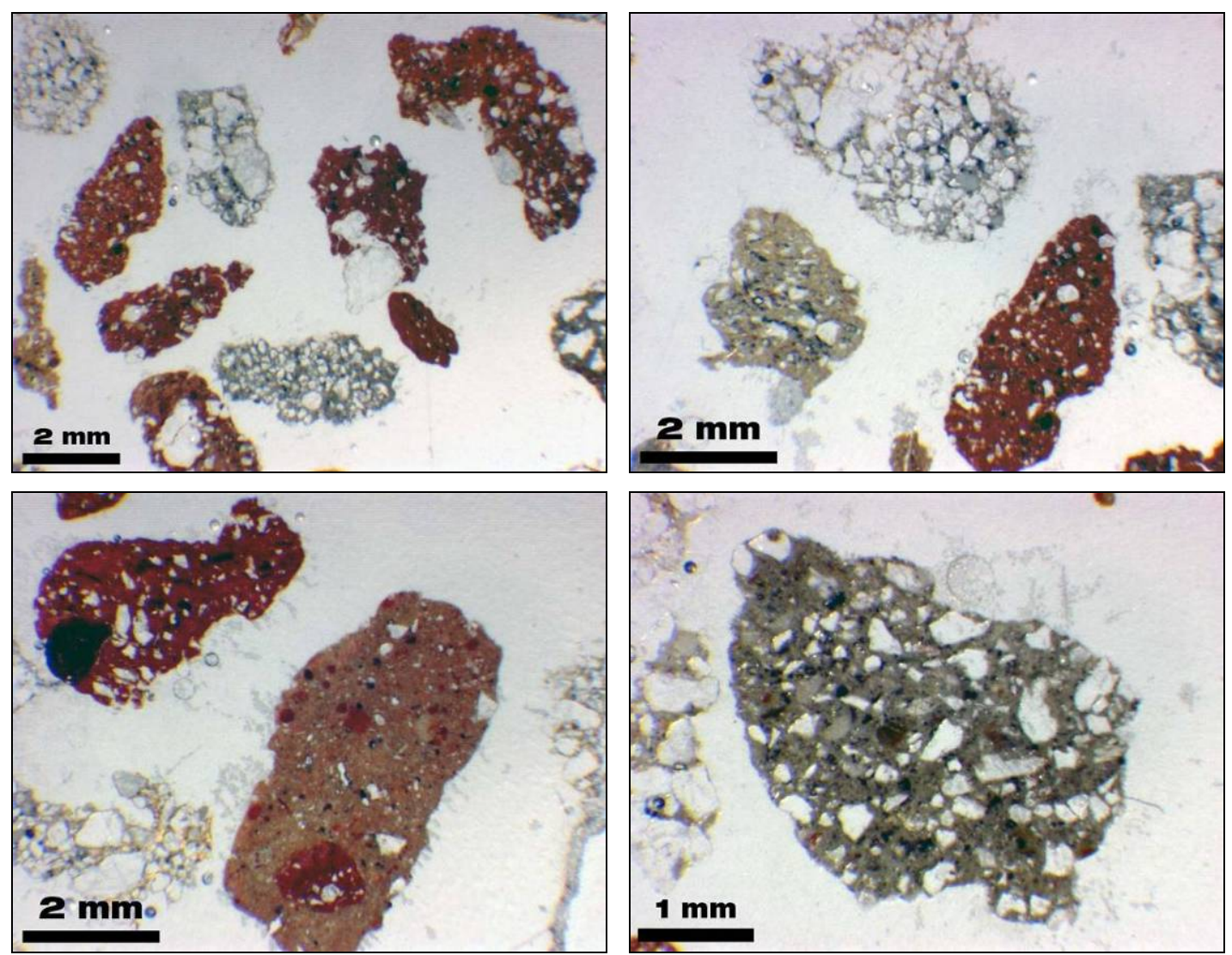

Fotografias em estereomicroscópio $(-4,8+2,4 \mathrm{~mm})$
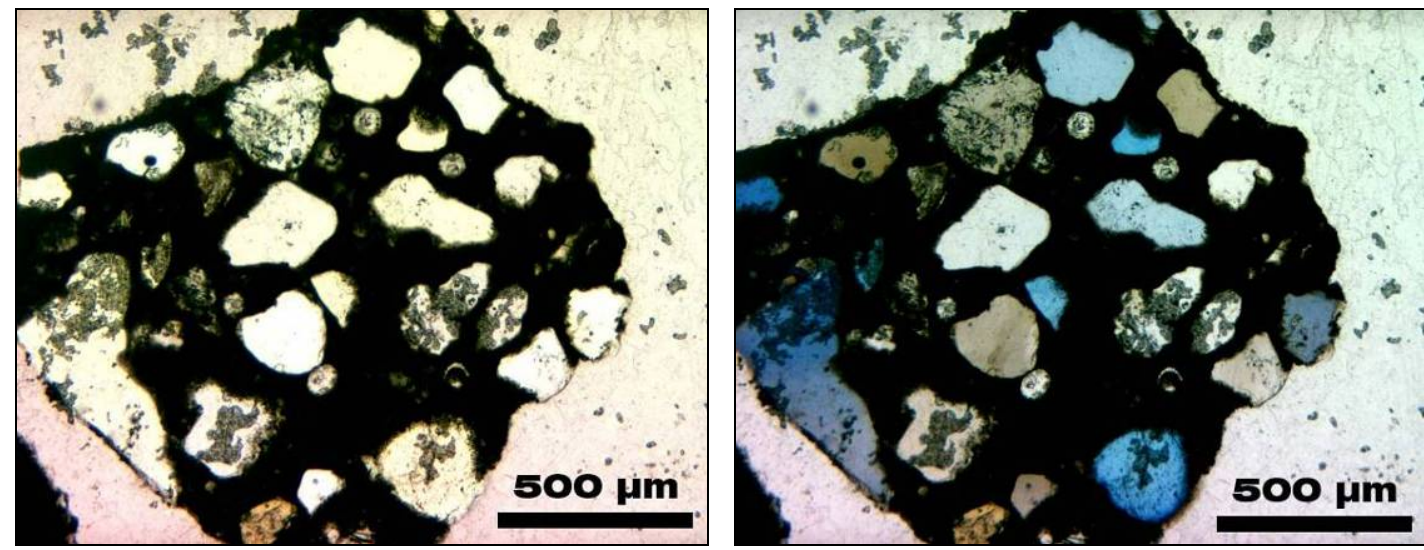

Fotografias em microscópio de polarização por luz transmitida $(-2,4+1,2$ mm)

Figura 6.19 - Microfotografias da fração miúda dos produtos de densidade 1,9-2,2 g/cm de VI-V 


\subsubsection{Produtos de densidade entre 2,2 e $2,5 \mathrm{~g} / \mathrm{cm}^{3}$}

As seções delgadas polidas dos produtos de densidade entre 2,2 e $2,5 \mathrm{~g} / \mathrm{cm}^{3}$ para as três amostras estudadas são apresentadas a seguir, respectivamente:

- $\quad$ IT-C, Figuras 6.20 e 6.21

- $\quad$ IT-V, Figuras 6.20 e 6.22

- VI-V, Figuras 6.20 e 6.23

Os produtos de densidade entre $2,2 \mathrm{~g} / \mathrm{cm}^{3}$ e $2,5 \mathrm{~g} / \mathrm{cm}^{3}$ são compostos por duas populações bastante distintas de partículas, sendo algumas envoltas por uma pequena quantidade de aglomerantes, algumas vezes até completamente liberadas, e outras completamente cimentadas por aglomerantes. O material de Vinhedo é constituído por grande número de partículas cerâmicas liberadas ao passo que as partículas minerais mostram intima e intensa associação com aglomerantes, particularmente na forma de cimentação. IT-C apresenta ainda muitas partículas minerais associadas a pasta de cimento e cal, ao passo que essa característica se torna menos marcante em IT-V, com maior número de partículas isenta de aglomerantes.

\subsubsection{Produtos de densidade superior a $2,5 \mathrm{~g} / \mathrm{cm}^{3}$}

As seções delgadas polidas dos produtos de densidade superior a $2,5 \mathrm{~g} / \mathrm{cm}^{3}$ para as três amostras estudadas são apresentadas a seguir, respectivamente:

- $\quad$ IT-C, Figuras 6.24 e 6.25

- $\quad$ IT-V, Figuras 6.24 e 6.26

- VI-V, Figuras 6.24 e 6.27

Os produtos de densidade superior a $2,5 \mathrm{~g} / \mathrm{cm}^{3}$ apresentam partículas de minerais praticamente livres de aglomerantes; as porções escuras das fotografias sob iluminação ultravioleta referem-se aos próprios minerais ou agregados; resquícios de aglomerantes são raros e estão restritos ao contorno das partículas. Observa-se também uma menor quantidade de partículas cerâmicas, mesmo em VI-V. 


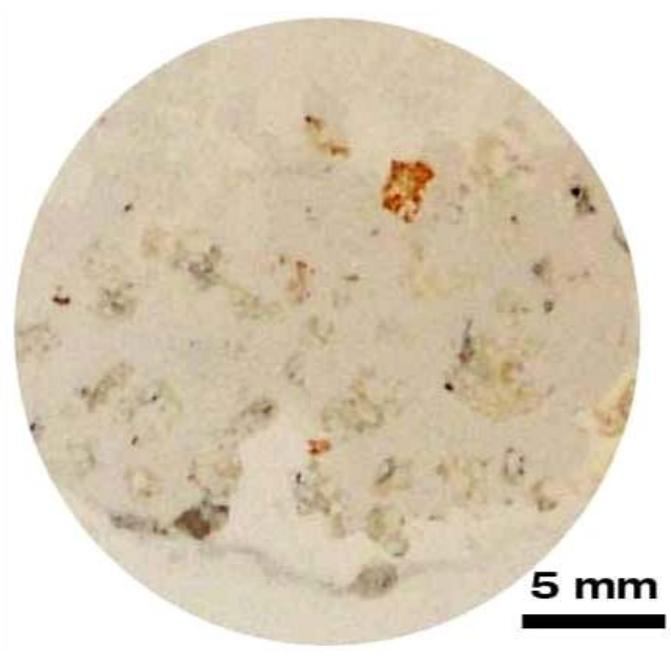

IT-C (-4,8+1,2 mm)

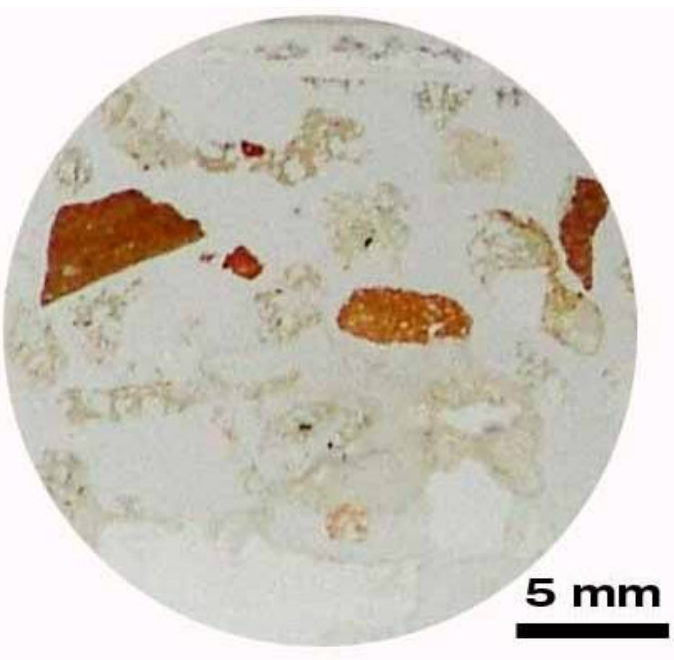

(a)

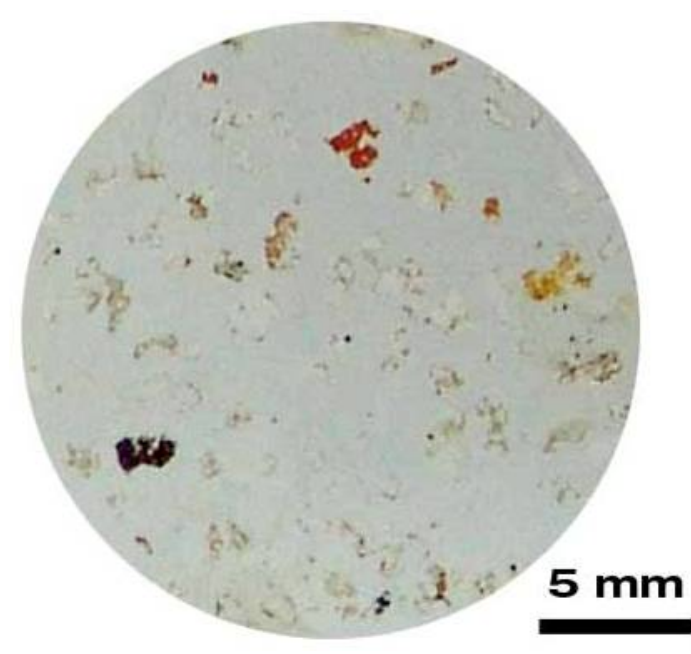

IT-V (-4,8+1,2 mm)

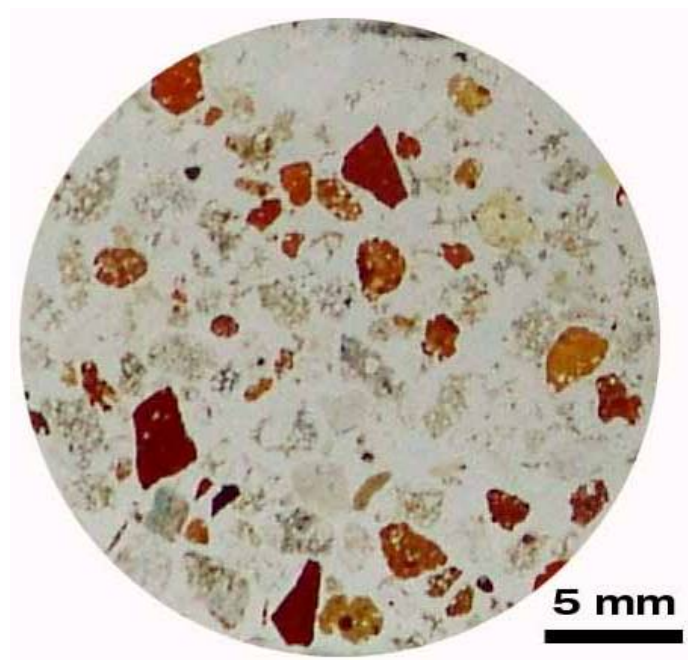

(b)

VI-V (a) -4,8+2,4 mm e (b) $-1,2+0,3 \mathrm{~mm}$

Figura 6.20 - Fotografias das seções delgadas polidas das frações miúdas dos produtos de densidade entre 2,2-2,5 g/ $\mathrm{cm}^{3}$ de IT-C, IT-V e VI-V 

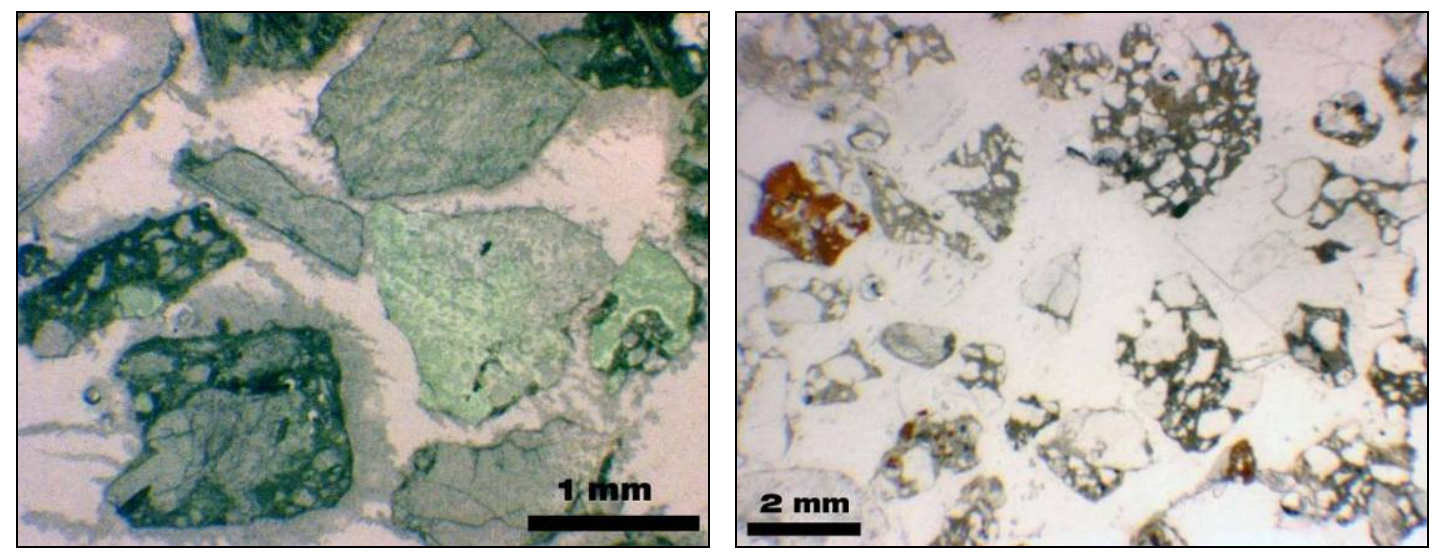

Fotografias em estereomicroscópio $(-4,8+1,2 \mathrm{~mm})$
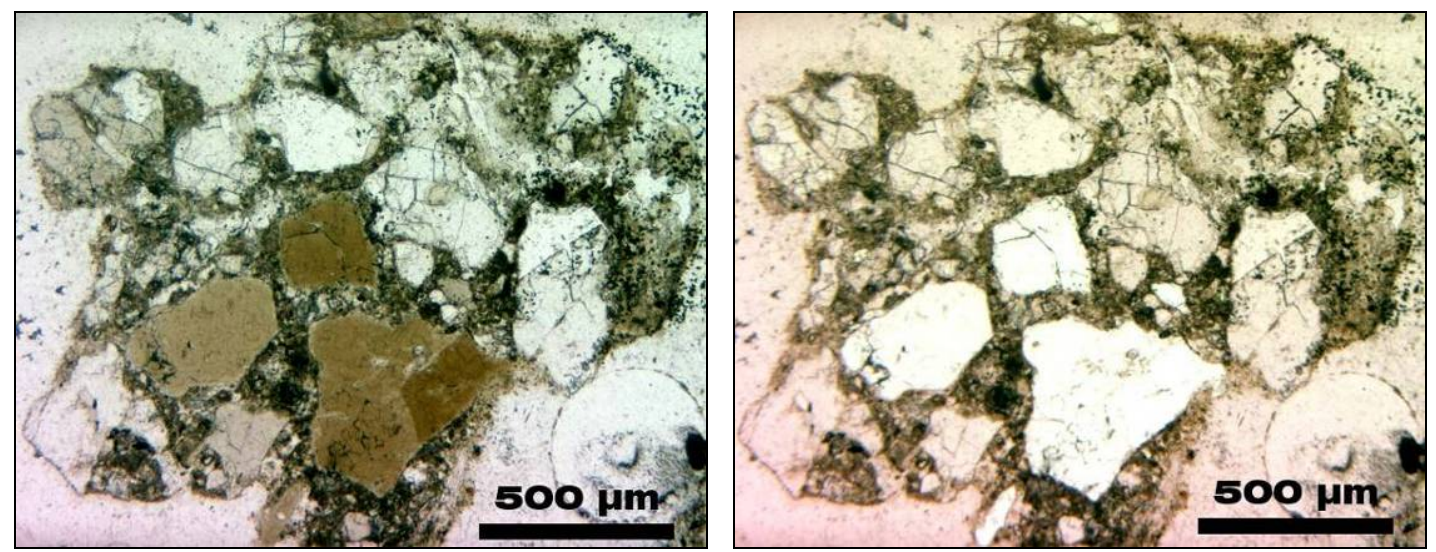

Fotografias em microscópio de polarização por luz transmitida $(-4,8+1,2 \mathrm{~mm})$
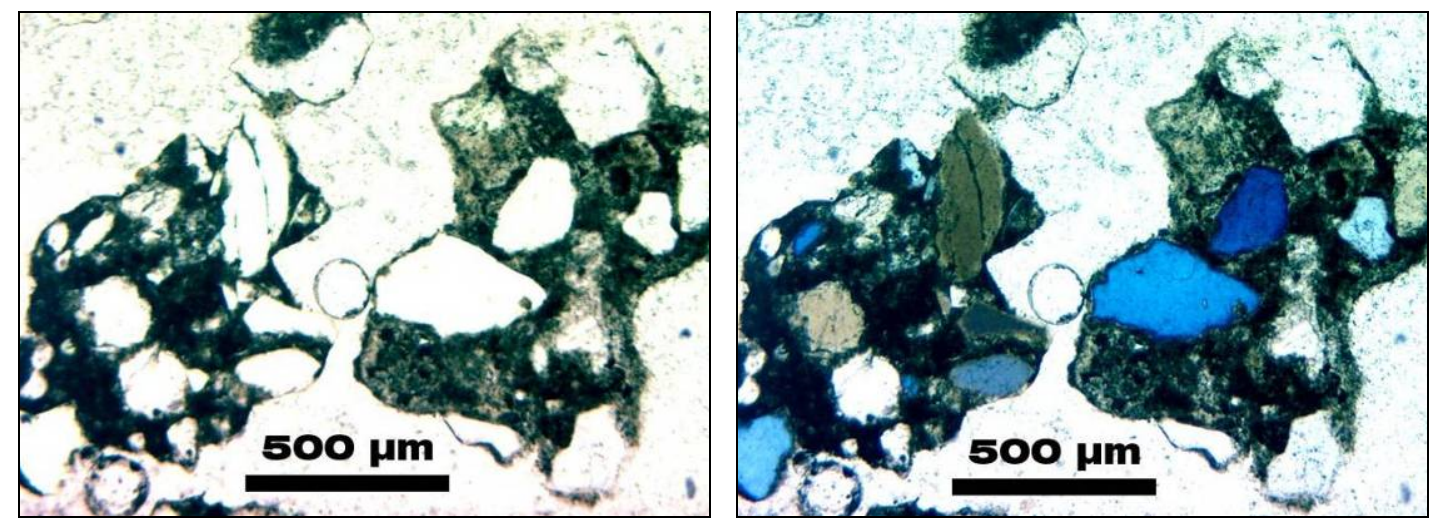

Fotografias em microscópio de polarização por luz transmitida (-1,2+0,3 mm)

Figura 6.21 - Microfotografias da fração miúda dos produtos de densidade 2,2-2,5 g/cm³ de IT-C 
Itaquera vermelho - 2,2 -2,5 g/cm3
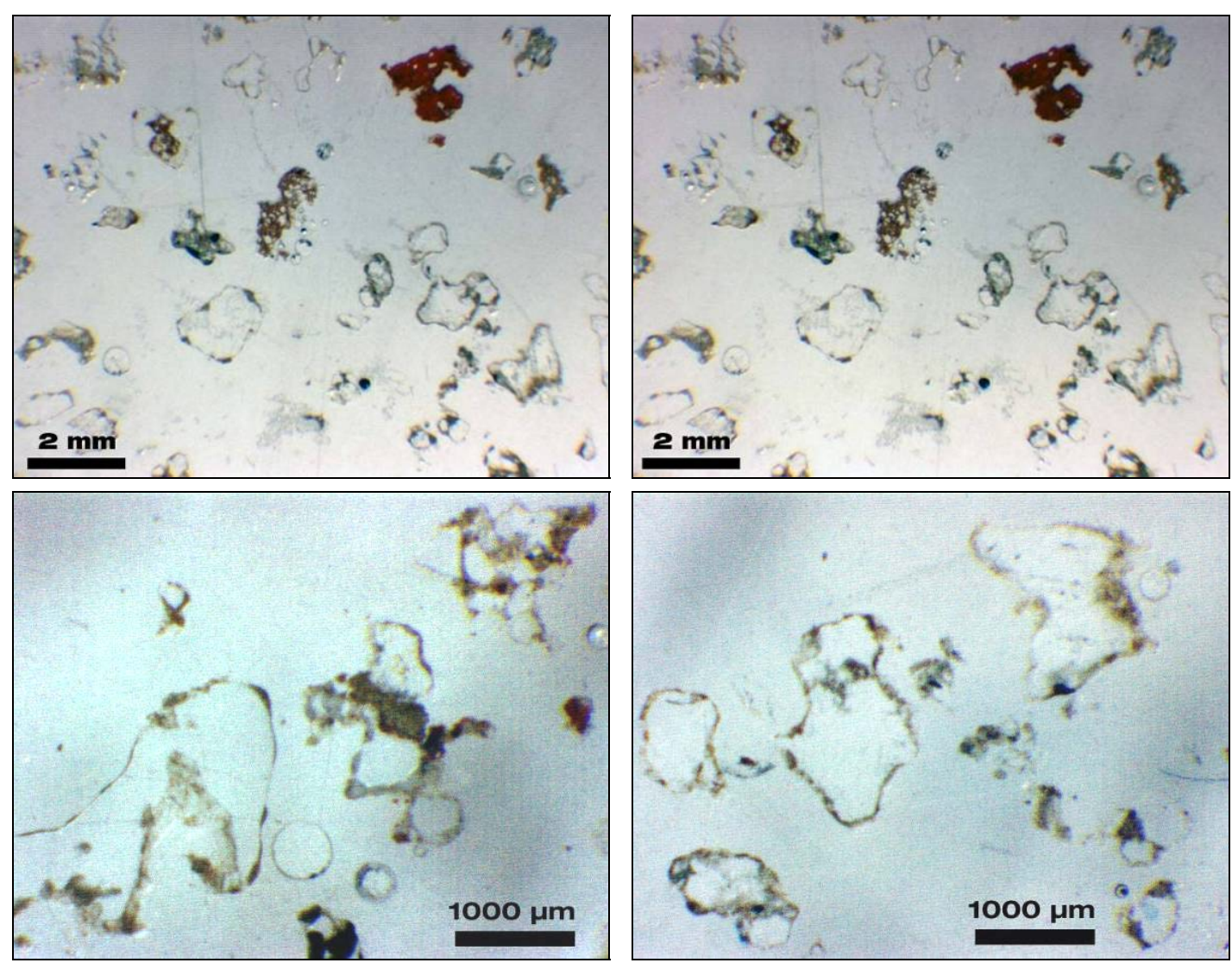

Fotografias em estereomicroscópio $(-4,8+1,2 \mathrm{~mm})$
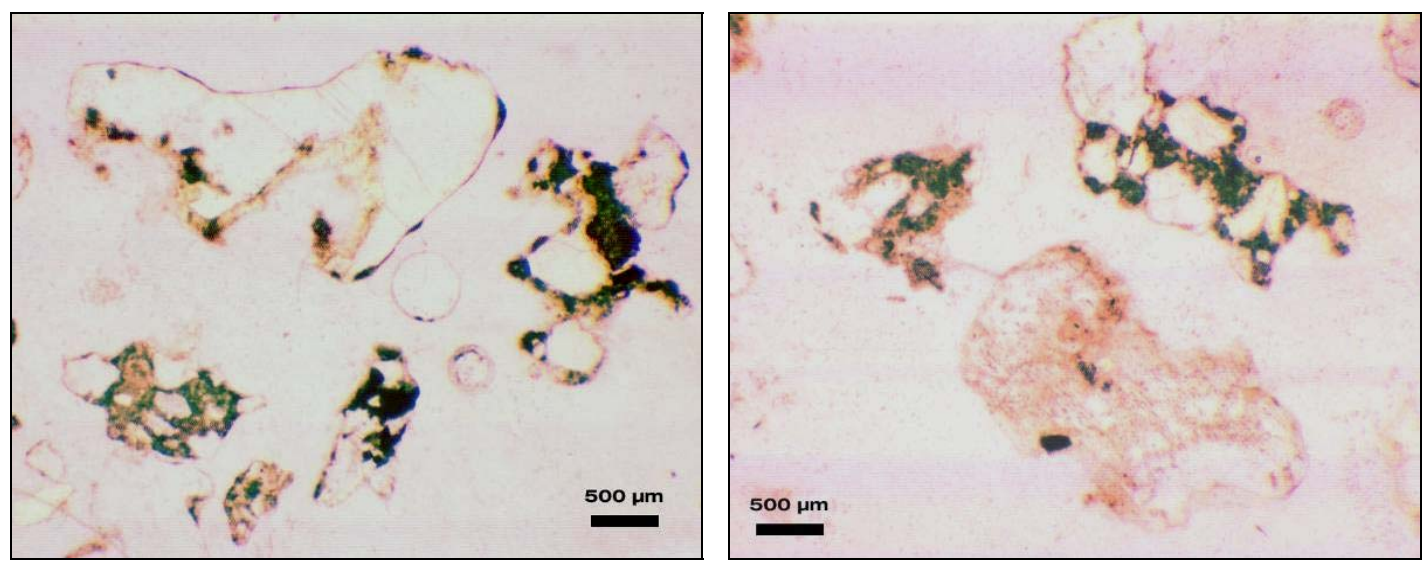

Fotografias em microscópio de polarização por luz transmitida $(-4,8+1,2$ mm)

Figura 6.22 - Microfotografias da fração miúda dos produtos de densidade 2,2-2,5 g/. $\mathrm{cm}^{3}$ de IT-V 
Vinhedo vermelho - $2,2-2,5 \mathrm{~g} / \mathrm{cm}^{3}$
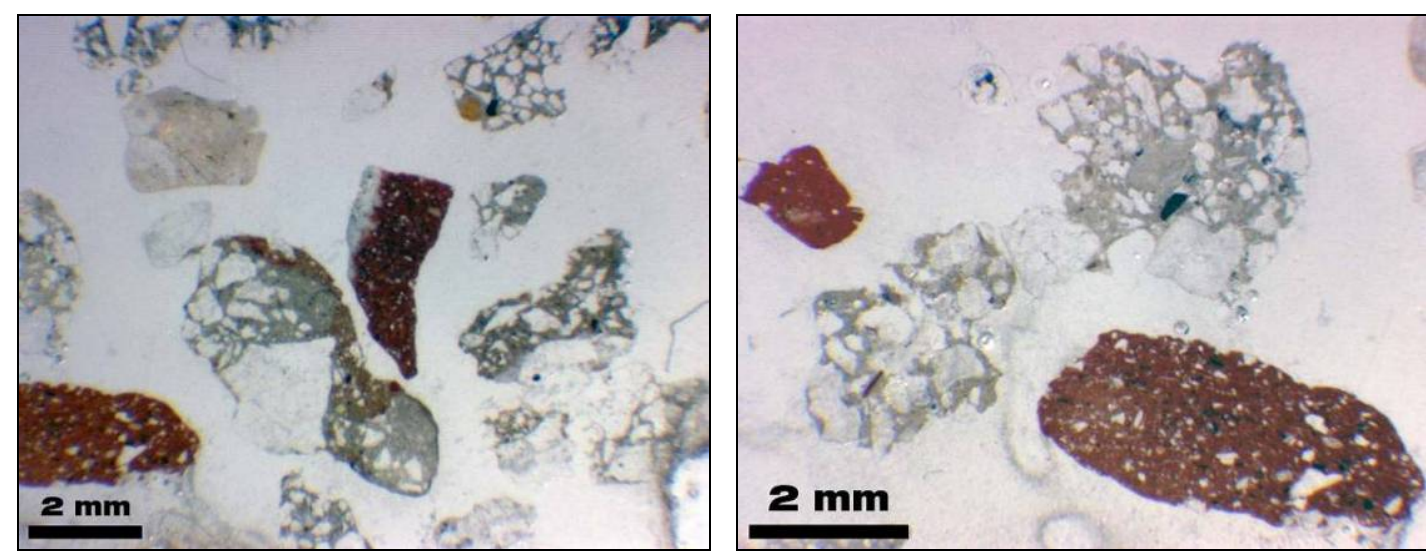

Fotografias em estereomicroscópio $(-4,8+2,4 \mathrm{~mm})$
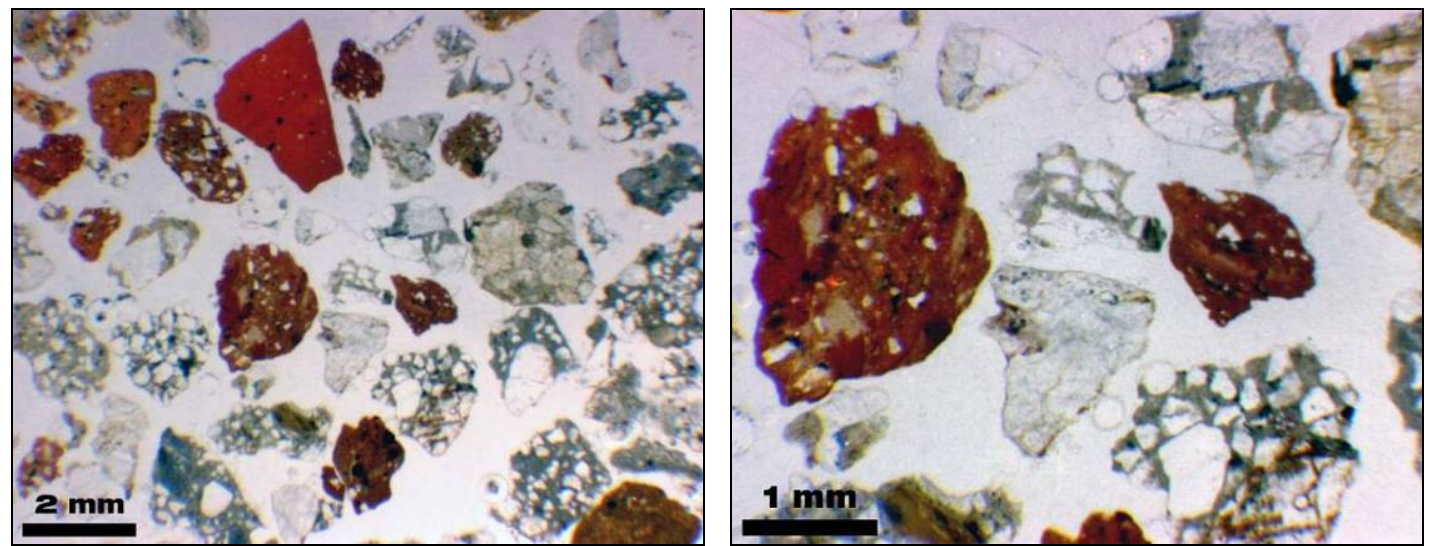

Fotografias em estereomicroscópio $(-2,4+1,2 \mathrm{~mm})$
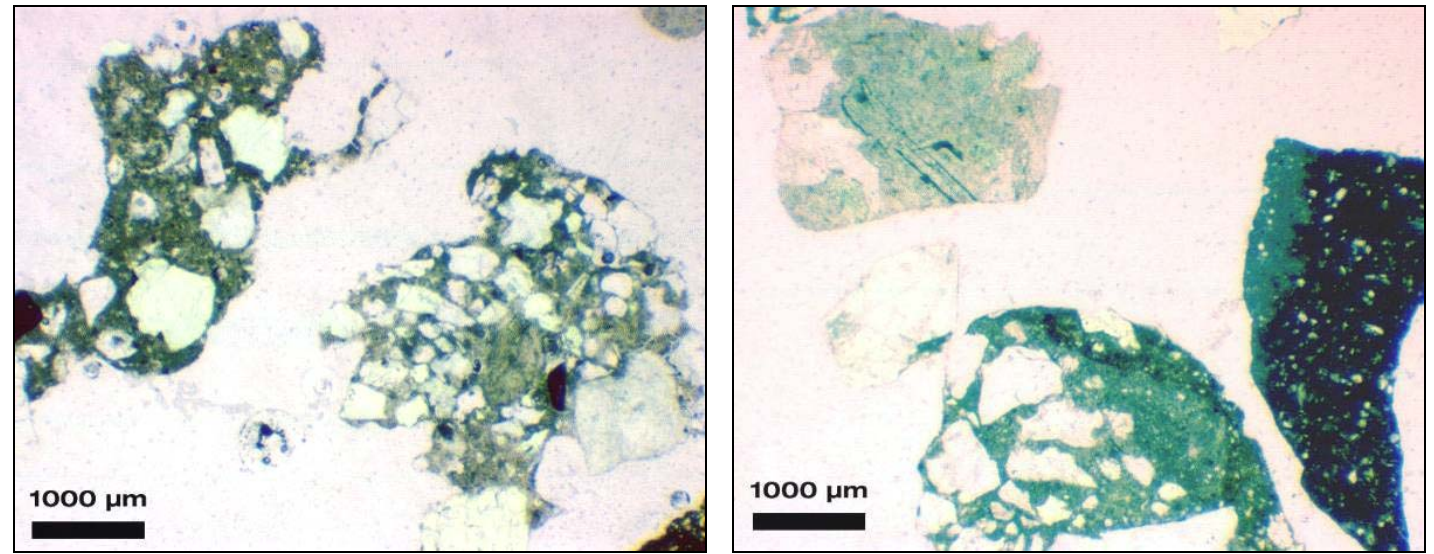

Fotografias em microscópio de polarização por luz transmitida (-2,4+1,2 mm)

Figura 6.23 - Microfotografias da fração miúda dos produtos de densidade 2,2-2,5 g/ $\mathrm{cm}^{3} \mathrm{de}$ VI-V 


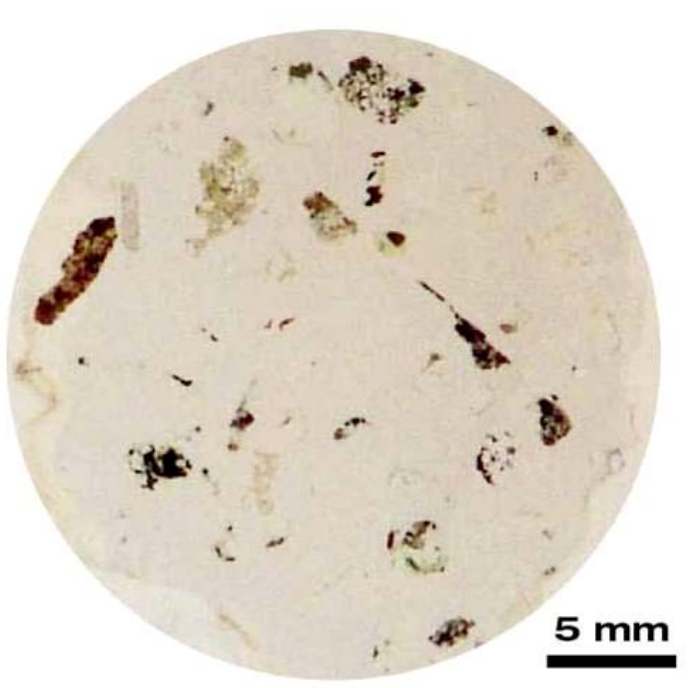

IT-C $(-4,8+1,2 \mathrm{~mm})$

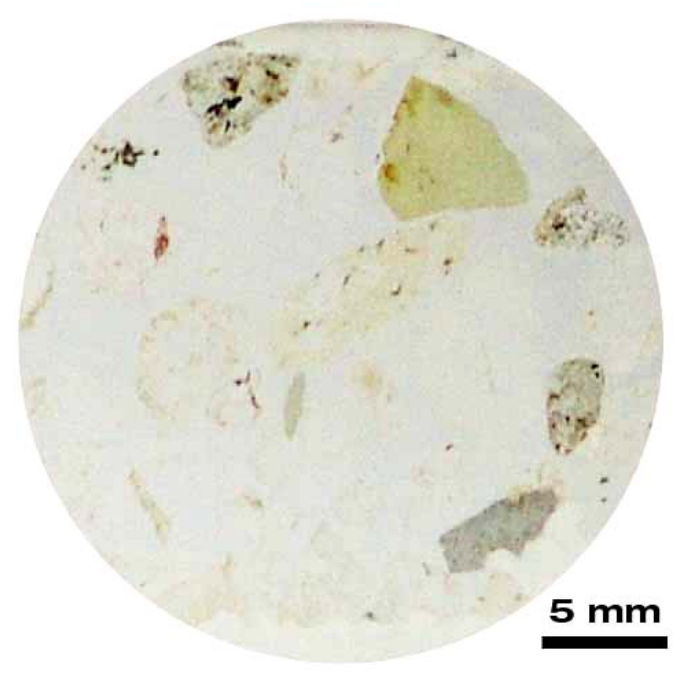

(a)

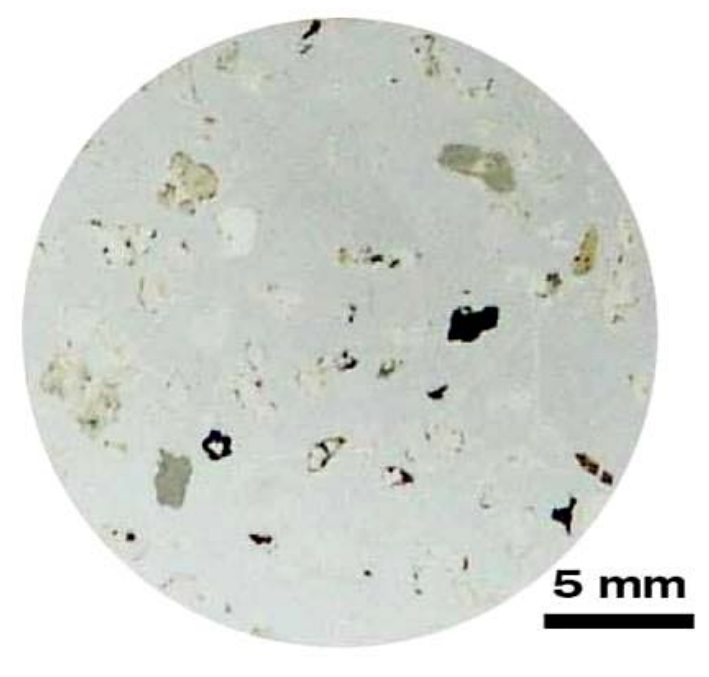

IT-V (-4,8+1,2 mm)

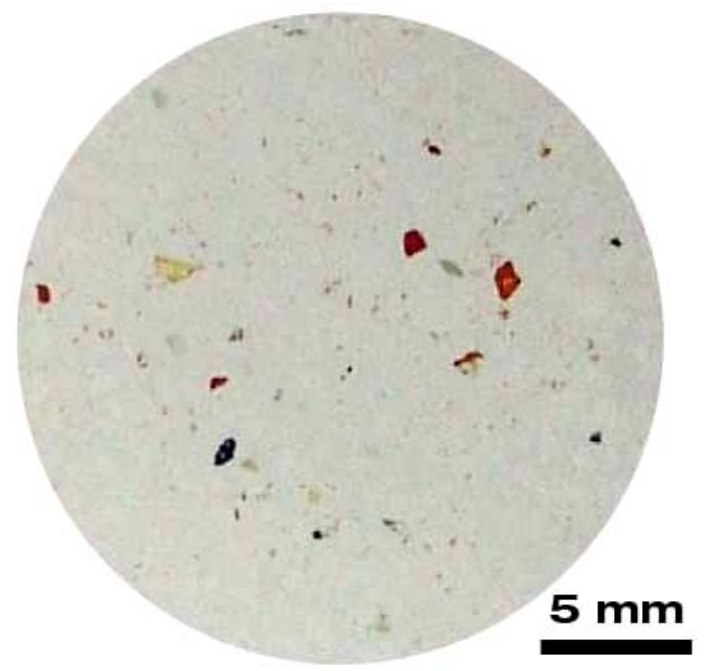

(b)

VI-V (a) -4,8+2,4 mm e (b) $-1,2+0,3 \mathrm{~mm}$

Figura 6.24 - Fotografias das seções delgadas polidas das frações miúdas dos produtos de densidade superior a $2,5 \mathrm{~g} / \mathrm{cm}^{3}$ de IT-C, IT-V e VI-V 
Itaquera cinza $>2,5 \mathrm{~g} / \mathrm{cm}^{3}$
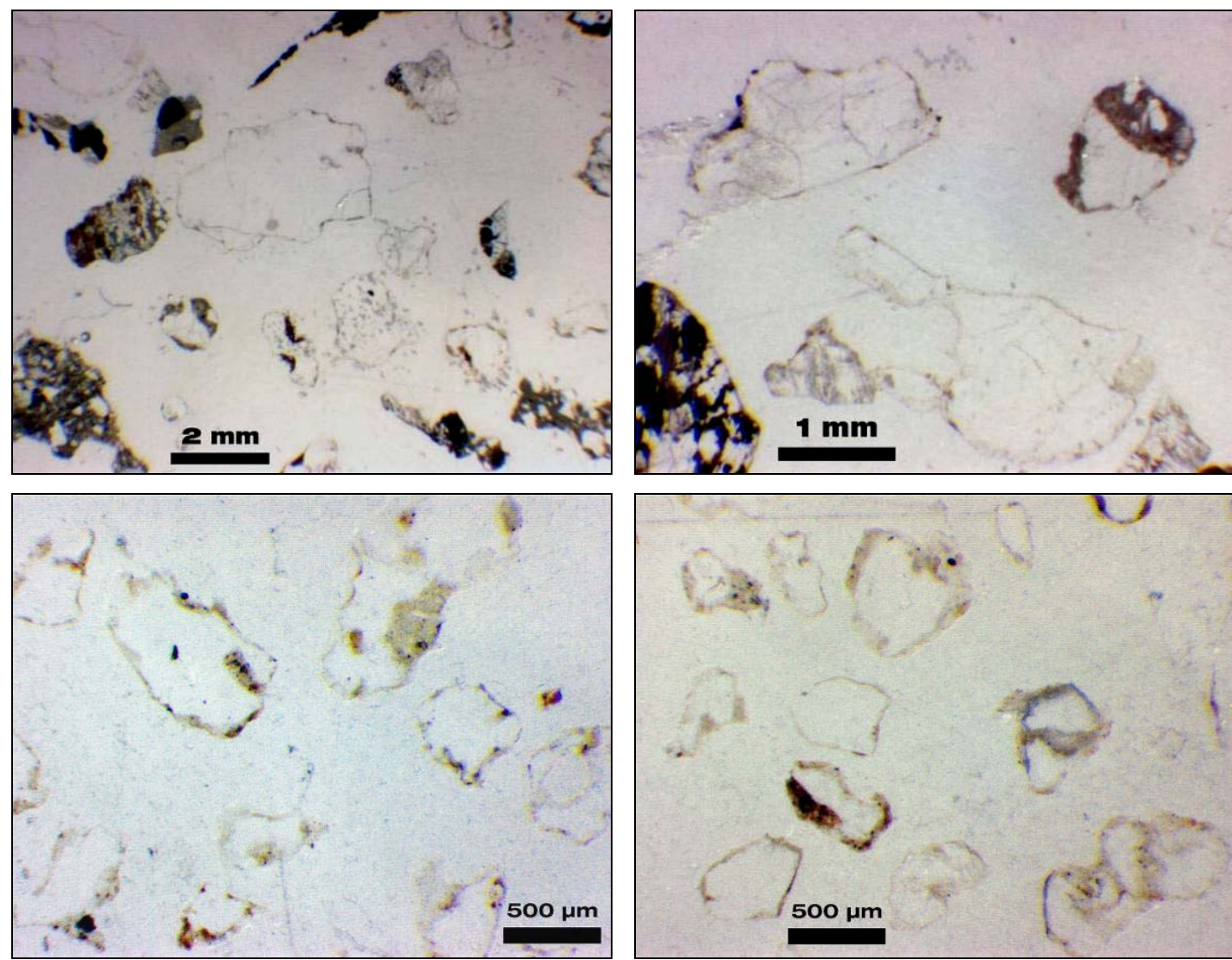

Fotografias em estereomicroscópio $(-4,8+1,2 \mathrm{~mm})$
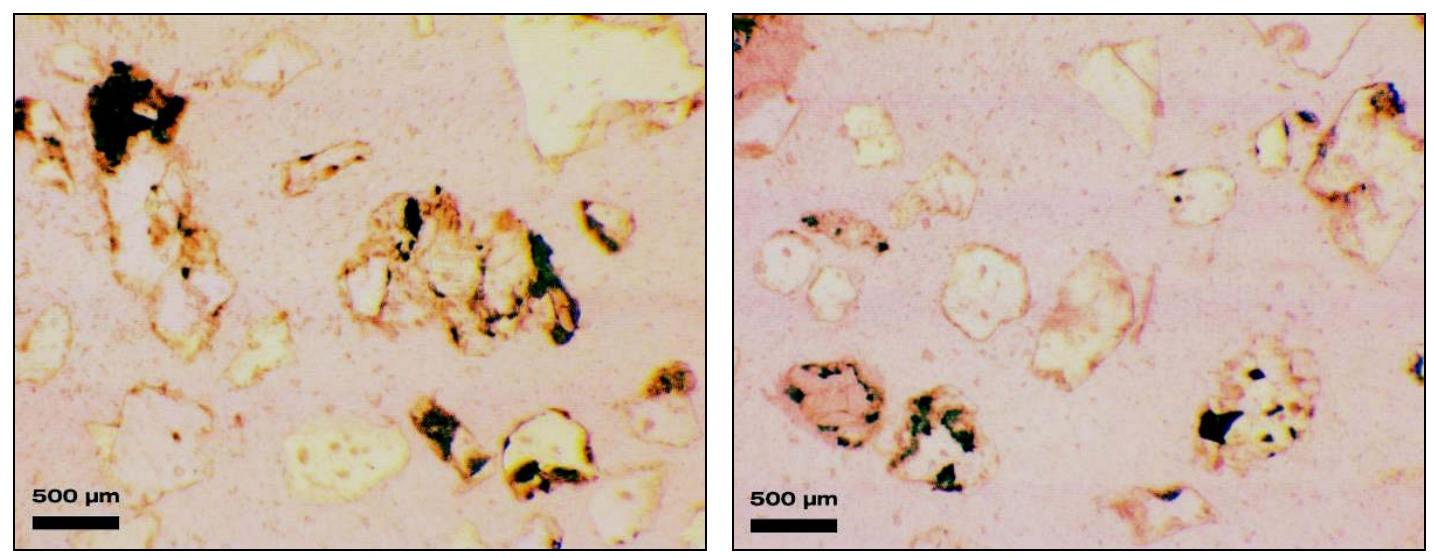

Fotografias em microscópio de polarização por luz transmitida (-4,8+1,2 mm)

Figura 6.25 - Microfotografias da fração miúda dos produtos de densidade superior a 2,5 g/ $\mathrm{cm}^{3}$ de IT-C 
Itaquera vermelho $>2,5 \mathrm{~g} / \mathrm{cm}^{3}$
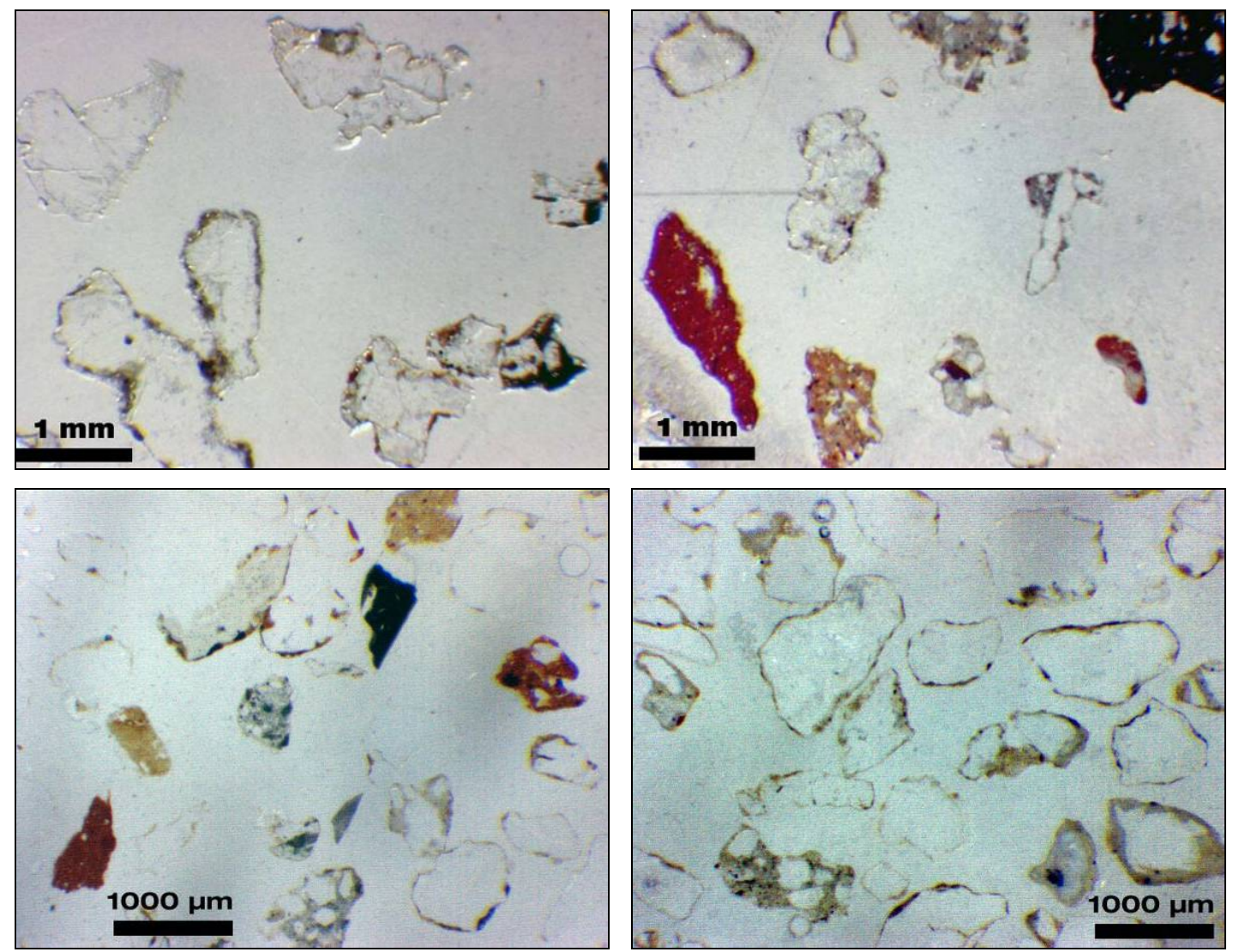

Fotografias em estereomicroscópio $(-4,8+1,2 \mathrm{~mm})$
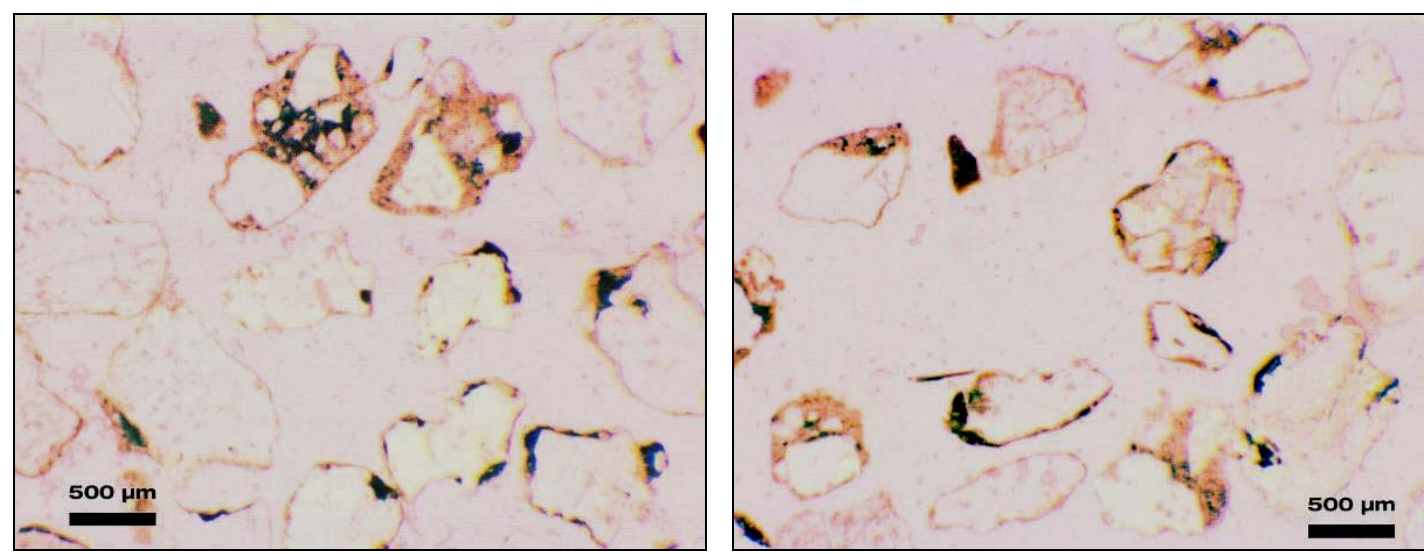

Fotografias em microscópio de polarização por luz transmitida (-4,8+1,2 mm)

Figura 6.26 - Microfotografias da fração miúda dos produtos de densidade superior a 2,5 g/ $\mathrm{cm}^{3}$ de IT-V 
Vinhedo vermelho $>2,5 \mathrm{~g} / \mathrm{cm}^{3}$
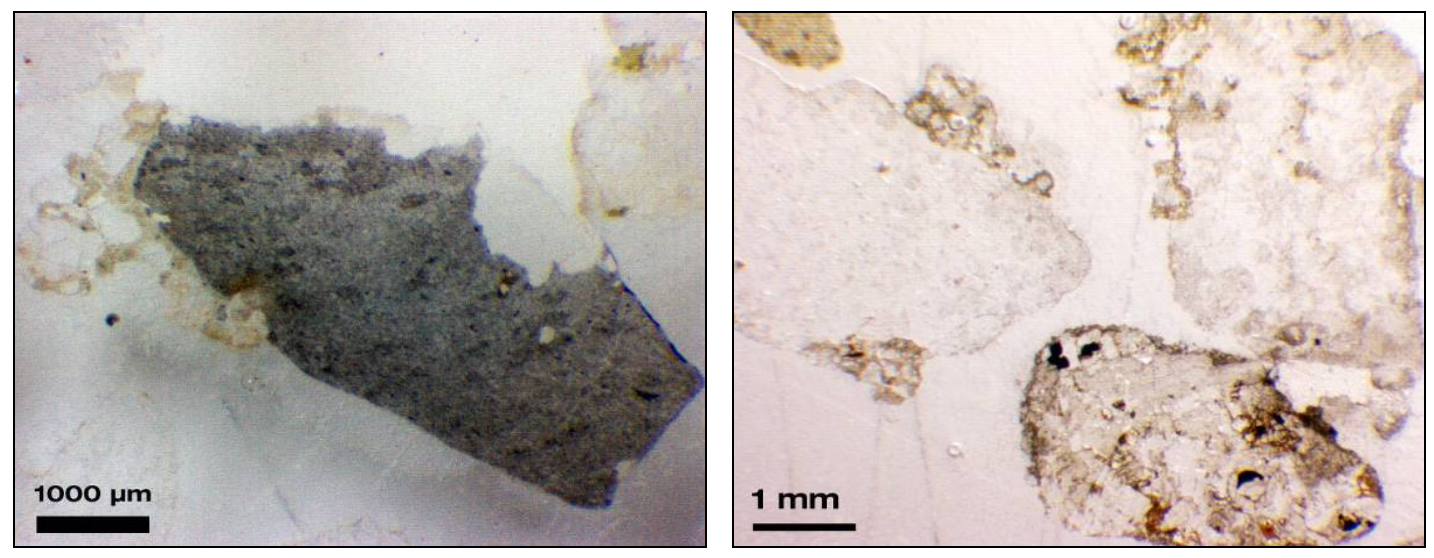

Fotografias em estereomicroscópio (-4,8+2,4 mm)
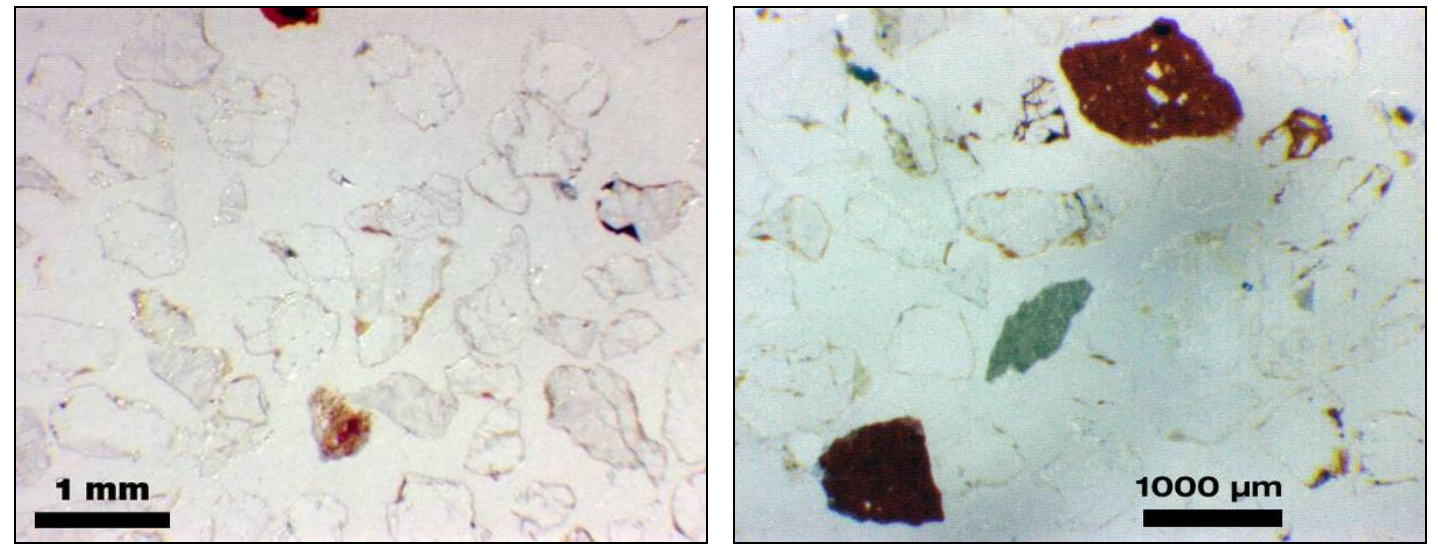

Fotografias em estereomicroscópio $(-1,2+0,3 \mathrm{~mm})$
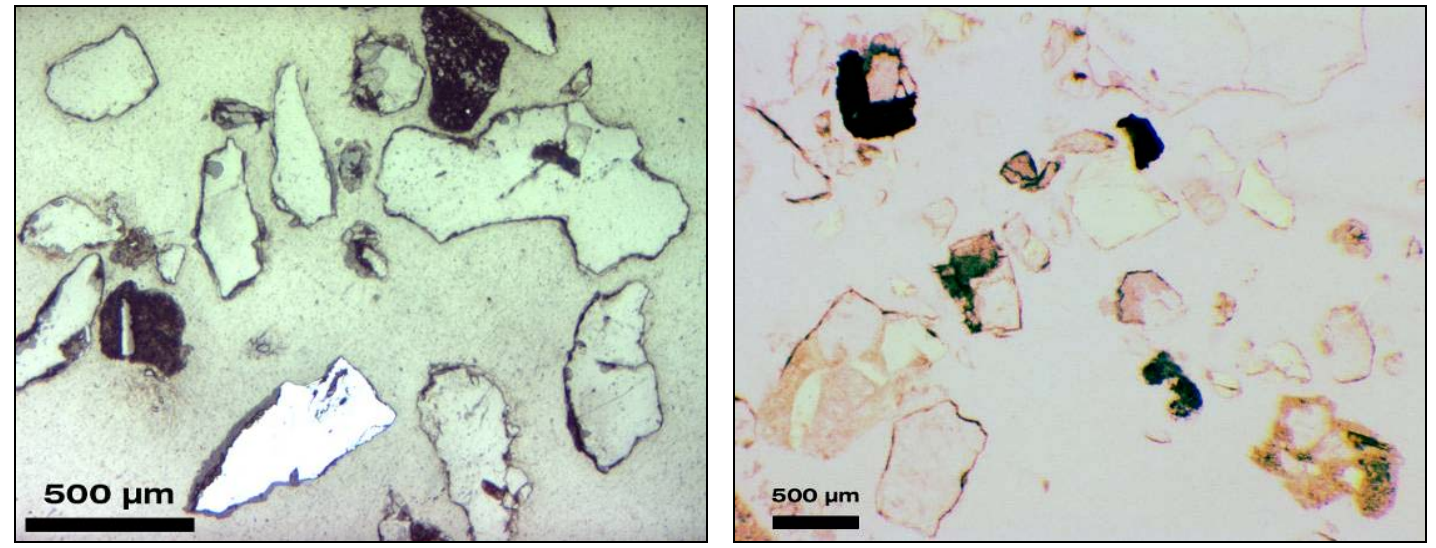

Fotografias em microscópio de polarização por luz transmitida $(-4,8+2,4 \mathrm{~mm})$

Figura 6.27 - Microfotografias da fração miúda dos produtos de densidade superior a 2,5 g/cm de VI-V 


\section{CARACTERIZAÇÃO DAS PROPRIEDADES FÍSICAS}

\subsection{DETERMINAÇOES DE MASSA ESPECÍFICA}

\subsubsection{Massa específica aparente}

Os resultados dos ensaios para determinação da massa específica aparente (MEA) para os vários produtos de separações em líquido denso da fração graúda e miúda estão sumariados nas Tabelas 7.1 e 7.2, respectivamente.

Tabela 7.1 - Massa específica aparente para os produtos graúdos

\begin{tabular}{|c|c|c|c|c|c|c|c|c|c|}
\hline \multirow{3}{*}{ Fração $(\mathrm{mm})$} & \multicolumn{9}{|c|}{ Separação por líquidos densos $\left(\mathrm{g} / \mathrm{cm}^{3}\right)$} \\
\hline & \multicolumn{3}{|c|}{$1,9<d<2,2$} & \multicolumn{3}{|c|}{$2,2<d<2,5$} & \multicolumn{3}{|c|}{$d>2,5$} \\
\hline & IT-C & IT-V & VI-V & IT $-C$ & IT-V & VI-V & IT $-C$ & IT-V & VI-V \\
\hline$-25,4+19,1$ & 2,03 & 1,99 & 1,93 & 2,34 & 2,14 & 2,27 & 2,60 & 2,62 & 2,61 \\
\hline$-19,1+12,7$ & 1,99 & 2,02 & 1,90 & 2,18 & 2,12 & 2,24 & 2,59 & 2,55 & 2,62 \\
\hline$-12,7+9,52$ & 1,93 & 1,98 & 1,83 & 2,15 & 2,12 & 2,15 & 2,63 & 2,59 & 2,67 \\
\hline$-9,52+4,8$ & 1,95 & 1,88 & 1,96 & 2,11 & 2,15 & 2,09 & 2,60 & 2,60 & 2,58 \\
\hline Média** & 1,98 & 1,96 & 1,91 & 2,20 & 2,13 & 2,21 & 2,60 & 2,59 & 2,62 \\
\hline
\end{tabular}

** Média ponderada pelas proporções em massa de cada fração granulométrica Valores expressos em $\mathrm{g} / \mathrm{cm}^{3}$

Tabela 7.2 - Massa específica aparente para os produtos miúdos

\begin{tabular}{|c|c|c|c|c|c|c|c|c|c|}
\hline \multirow{3}{*}{ Fração (mm) } & \multicolumn{9}{|c|}{ Separação por líquidos densos $\left(\mathrm{g} / \mathrm{cm}^{3}\right)$} \\
\hline & \multicolumn{3}{|c|}{$1,9<d<2,2$} & \multicolumn{3}{|c|}{$2,2<d<2,5$} & \multicolumn{3}{|c|}{$d>2,5$} \\
\hline & IT-C & IT-V & VI-V & IT- $C$ & IT-V & VI-V & IT $-C$ & IT-V & VI-V \\
\hline$-4,8+2,4$ & \multirow{2}{*}{$\star$} & \multirow{2}{*}{ * } & 1,79 & \multirow{2}{*}{2,12} & \multirow{2}{*}{2,12} & 2,06 & \multirow{2}{*}{2,68} & \multirow{2}{*}{ * } & 2,56 \\
\hline$-2,4+1,2$ & & & * & & & 2,10 & & & 2,58 \\
\hline$-1,2+0,3$ & * & * & * & * & * & 2,29 & 2,51 & 2,46 & 2,43 \\
\hline Média** & * & * & 1,79 & 2,12 & 2,12 & 2,19 & 2,62 & 2,46 & 2,50 \\
\hline
\end{tabular}

* Insuficiência de material para a realização dos ensaios; ** Média ponderada pelas proporções em massa de cada fração granulométrica

Valores expressos em $\mathrm{g} / \mathrm{cm}^{3}$ 
Embora grande parte da fração miúda não tenha sido analisada por insuficiência de massa, nota-se que os valores médios de massa específica aparente das frações graúda e miúda são muito próximos e também variam pouco ao longo do intervalo granulométrico.

\subsubsection{Massa específica real}

Na Tabela 7.3 estão expostos os resultados do ensaio para determinação de massa específica real em picnômetro com intrusão de gás hélio dos produtos gerados nas separações em líquido denso.

Tabela 7.3 - Massa específica determinada por intrusão de gás hélio

\begin{tabular}{|c|c|c|c|c|c|c|c|c|c|}
\hline \multirow{3}{*}{ Fração $(\mathrm{mm})$} & \multicolumn{9}{|c|}{ Separação por líquidos densos $\left(\mathrm{g} / \mathrm{cm}^{3}\right)$} \\
\hline & \multicolumn{3}{|c|}{$1,9<d<2,2$} & \multicolumn{3}{|c|}{$2,2<d<2,5$} & \multicolumn{3}{|c|}{$d>2,5$} \\
\hline & IT $-C$ & IT-V & VI-V & IT-C & IT-V & VI-V & IT $-C$ & IT-V & VI-V \\
\hline$-25,4+19,1$ & 2,587 & 2,622 & 2,617 & 2,784 & 2,645 & 2,587 & 2,744 & 2,670 & 2,627 \\
\hline$-19,1+12,7$ & 2,654 & 2,693 & 2,650 & 2,653 & 2,621 & 2,616 & 2,748 & 2,698 & 2,669 \\
\hline$-12,7+9,52$ & 2,642 & 2,675 & 2,611 & 2,695 & 2,634 & 2,667 & 2,700 & 2,712 & 2,703 \\
\hline$-9,52+4,8$ & 2,570 & 2,674 & 2,671 & 2,618 & 2,625 & 2,640 & 2,718 & 2,720 & 2,666 \\
\hline$-4,8+1,2$ & 2,553 & 2,683 & 2,666 & 2,700 & 2,669 & 2,637 & 2,713 & 2,707 & 2,672 \\
\hline$-1,2+0,3$ & 2,807 & 2,762 & - & 2,736 & 2,736 & 2,652 & 2,674 & 2,696 & 2,648 \\
\hline Média** & 2,632 & 2,687 & 2,644 & 2,695 & 2,654 & 2,625 & 2,721 & 2,704 & 2,661 \\
\hline
\end{tabular}

* Insuficiência de material para a realização dos ensaios; ** Média ponderada pelas proporções em massa de cada fração granulométrica

Valores expressos em $\mathrm{g} / \mathrm{cm}^{3}$

Independentemente dos intervalos de densidade dos produtos de meio denso, verifica-se que os valores de massa específica real se assemelham bastante entre si, já que estes últimos consideram os grãos minerais não o agregado propriamente dito; sendo assim, conclui-se que a porosidade é bastante influente na separação em líquidos densos, sendo que os produtos compreendidos entre as faixas de menor densidade são os mais porosos, diminuindo à medida que se aumentam os valores de densidade de corte ou separação. 


\subsection{ABSORÇÃO DE ÁGUA}

Os resultados dos ensaios para determinação absorção de água para os vários produtos de separações em líquido denso da fração graúda e miúda são apresentados nas Tabelas 7.4 e 7.5 , respectivamente.

Tabela 7.4 - Absorção de água para os produtos graúdos

\begin{tabular}{|c|c|c|c|c|c|c|c|c|c|}
\hline \multirow{3}{*}{ Fração $(\mathrm{mm})$} & \multicolumn{9}{|c|}{ Separação por líquidos densos $\left(\mathrm{g} / \mathrm{cm}^{3}\right)$} \\
\hline & \multicolumn{3}{|c|}{$1,9<d<2,2$} & \multicolumn{3}{|c|}{$2,2<d<2,5$} & \multicolumn{3}{|c|}{$d>2,5$} \\
\hline & IT - $C$ & IT-V & VI-V & IT $-C$ & IT-V & VI-V & IT - $C$ & IT-V & VI-V \\
\hline$-25,4+19,1$ & 7,1 & 11,6 & 7,9 & 3,8 & 7,1 & 4,3 & 0,7 & 0,9 & 1,3 \\
\hline$-19,1+12,7$ & 6,4 & 11,8 & 9,2 & 3,9 & 7,4 & 6,9 & 1,8 & 0,6 & 1,4 \\
\hline$-12,7+9,52$ & 6,5 & 14,7 & 10,3 & 5,5 & 8,2 & 6,4 & 1,1 & 0,3 & 1,0 \\
\hline$-9,52+4,8$ & 10,5 & 9,4 & 10,5 & 7,0 & 7,6 & 7,4 & 1,3 & 1,3 & 1,1 \\
\hline Média** & 7,5 & 11,6 & 9,2 & 4,8 & 7,6 & 6,2 & 1,3 & 0,8 & 1,3 \\
\hline
\end{tabular}

** Média ponderada pelas proporções em massa de cada fração granulométrica

Valores expressos em porcentagem (\%)

Tabela 7.5 - Absorção de água para os produtos miúdos

\begin{tabular}{|c|c|c|c|c|c|c|c|c|c|}
\hline \multirow{3}{*}{ Fração (mm) } & \multicolumn{9}{|c|}{ Separação por líquidos densos $\left(\mathrm{g} / \mathrm{cm}^{3}\right)$} \\
\hline & \multicolumn{3}{|c|}{$1,9<d<2,2$} & \multicolumn{3}{|c|}{$2,2<d<2,5$} & \multicolumn{3}{|c|}{$d>2,5$} \\
\hline & IT - $C$ & IT-V & VI-V & IT - $C$ & IT-V & VI-V & IT-C & IT-V & VI-V \\
\hline$-4,8+2,4$ & \multirow{2}{*}{ * } & \multirow{2}{*}{ * } & 18,3 & \multirow{2}{*}{9,5} & \multirow{2}{*}{10,3} & 12,0 & \multirow{2}{*}{1,8} & \multirow{2}{*}{ * } & 1,9 \\
\hline$-2,4+1,2$ & & & * & & & 11,2 & & & 2,0 \\
\hline$-1,2+0,3$ & $\star$ & * & * & * & * & 6,9 & 4,5 & 4,7 & 5,1 \\
\hline Média** & $\star$ & $\star$ & 18,3 & 9,5 & 10,3 & 9,2 & 2,7 & 4,7 & 3,6 \\
\hline
\end{tabular}

* Insuficiência de material para a realização dos ensaios; ** Média ponderada pelas proporções em massa de cada fração granulométrica

Valores expressos em porcentagem (\%)

Os valores de absorção de água aumentam para as frações granulométricas mais finas, sendo sistematicamente maiores para a fração miúda que para a graúda; as diferenças observadas entre os três RCD reciclados estudados são pouco expressivas.

Entre os intervalos de densidade dos produtos de meio denso, verifica-se que a absorção aumenta significativamente quanto menor o intervalo de densidade considerado, variando de cerca de 10 a próximo de $1 \%$ para a fração graúda e de 18,3 a 3,6\%, em média, para a fração miúda. 


\subsection{SUMÁRIO DAS PROPRIEDADES FÍSICAS}

As Figuras 7.1 e 7.2 mostram os resultados de massa específica aparente e absorção de água dos produtos graúdos para as diferentes classes e origem de RCD, por faixas granulométricas e densitárias.

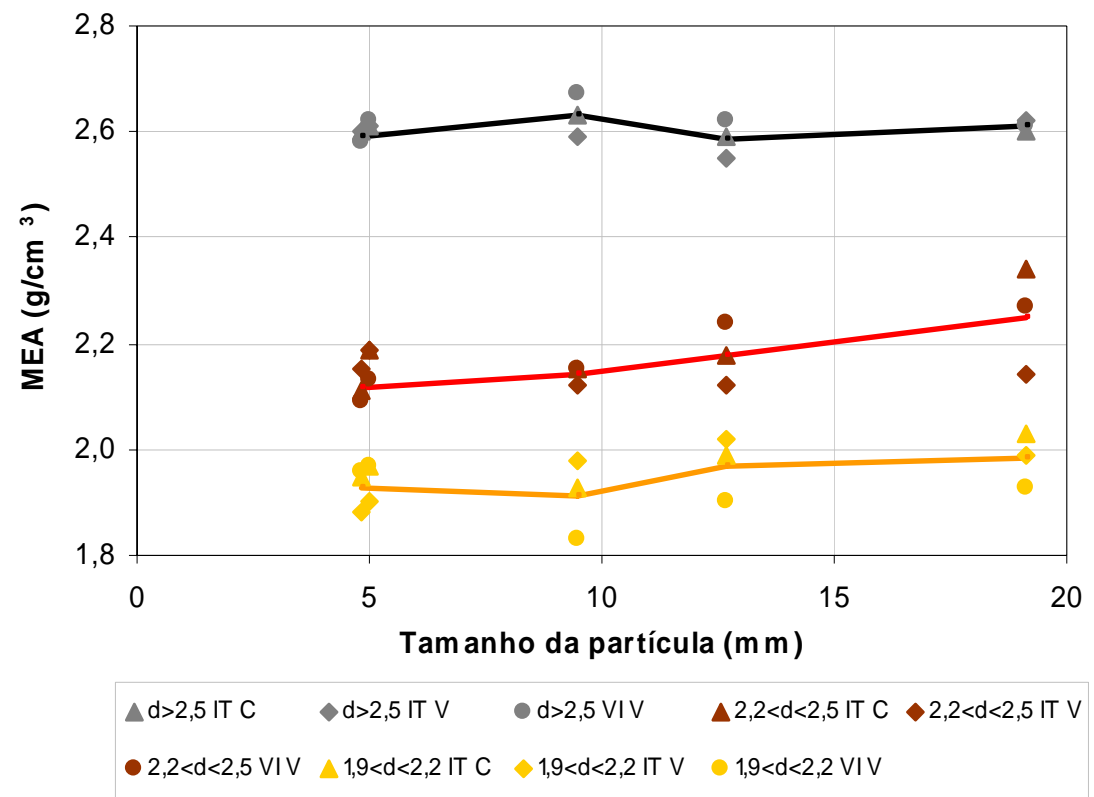

Figura 7.1 - Resultados de massa específica aparente dos produtos em função da fração retida em peneira, natureza ou origem do RCD e da separação por líquidos densos

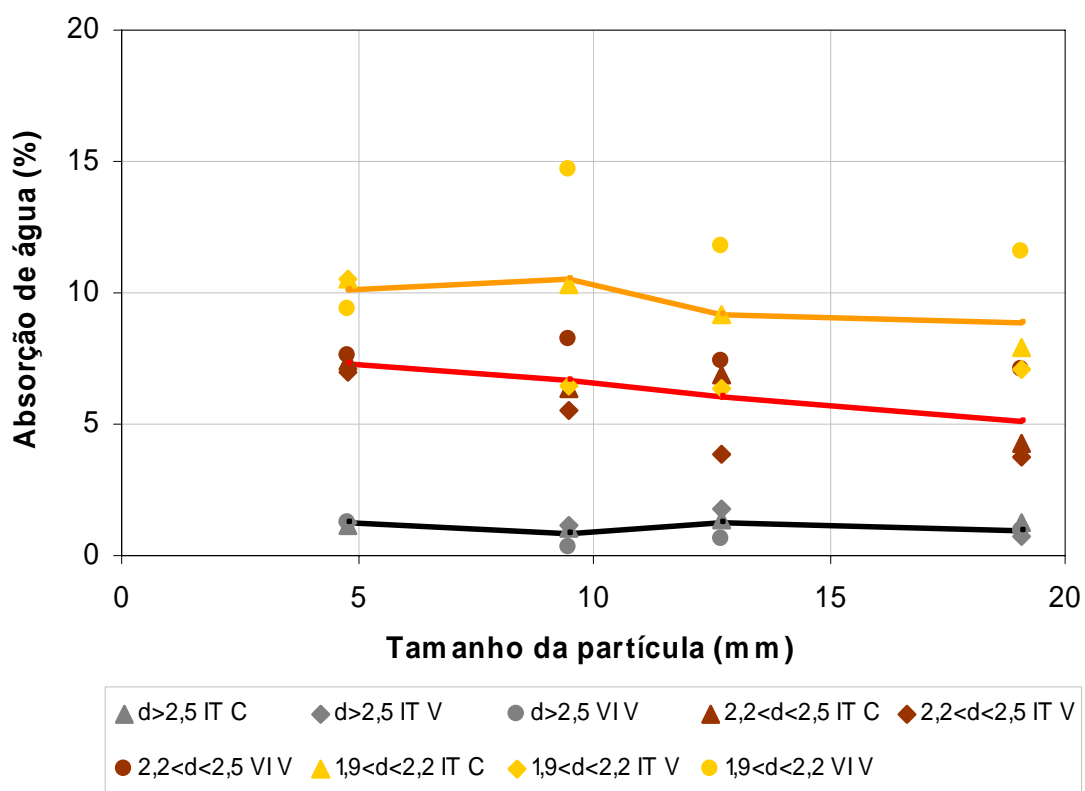

Figura 7.2 - Resultados de absorção de água (b) dos produtos em função da fração retida em peneira, natureza ou origem do RCD e da separação por líquidos densos 
Os resultados de absorção de água e massa específica aparente mostram que tais variáveis são essencialmente influenciadas pela densidade, independente da classe do $\mathrm{RCD}$; pode-se inferir, dessa forma, que os produtos vermelho e cinza apresentam a qualidades semelhantes quanto às propriedades físicas de agregados, embora seja comum acreditar que os resíduos do tipo cinza apresentem propriedades mecânicas superiores.

Já os produtos graúdos do tipo vermelho de Itaquera e Vinhedo apresentam distribuição em massa distinta nas classes de densidade, sendo que o produto de Itaquera é de melhor qualidade em relação ao produto de Vinhedo quanto às propriedades físicas de agregados; sendo assim a classificação visual baseada na cor do resíduo não se mostra uma ferramenta de controle de qualidade eficiente segundo estas propriedades físicas.

A separação por densidade pode ser empregada com o objetivo de se obter agregados graúdos de melhor qualidade uma vez que mais da metade da massa destes agregados (até $70 \%$ em Itaquera) possui características físicas (massa específica aparente e absorção de água) em atendimento à especificação Rilem (RILEM, 1994).

Os resultados do ensaio de MEA e líquidos densos apresentam valores muito semelhantes, entretanto a massa específica determinada por picnometria denota que a densidade real média dos grãos minerais é constante e da ordem de 2,6-2,7 g/ $\mathrm{cm}^{3}$, independente do intervalo de densidade considerado. Assim sendo, as diferenças observadas entre a massa específica real e aparente, não advém dos grãos de minerais e sim de outros fatores (aglomerantes, porosidade). A absorção de água, por sua vez, decresce com o aumento da densidade aparente.

Relacionando as propriedades de massa específica aparente, massa específica real e absorção de água, conclui-se que os produtos de menor densidade apresentam maiores quantidades de aglomerantes (pasta de cimento endurecida e cal) e estão, da mesma forma, relacionados à porosidade. Tais conclusões reforçam as informações obtidas pela análise química e microscopia óptica, discutidas anteriormente nos capítulos 5 e 6 , respectivamente. 


\section{CONSIDERAÇÕES FINAIS}

\subsection{SUMÁRIO DOS RESULTADOS}

Os principais óxidos constituintes dos RCD de Itaquera (IT-C e IT-V) e Vinhedo (VI-V) são sílica, alumina e óxido de cálcio. Os resultados de análises químicas mostram que os teores analisados são essencialmente variáveis em função da granulometria, independendo da classe do RCD (cinza ou vermelho).

A sílica, alumina e óxido de cálcio são provenientes dos diversos tipos de silicatos dos agregados naturais, constituintes da pasta de cimento endurecida e de materiais cerâmicos. $\mathrm{O}$ óxido de cálcio está particularmente relacionado ao aglomerante (pasta de cimento endurecida, cal, gesso, etc) presente em componentes construtivos, visto que os agregados naturais são essencialmente de natureza granítica/gnáissica; esta situação, no entanto, não é válida para regiões que utilizam agregados de rocha calcária, nas quais a sua composição é significativamente diferente.

Os teores de $\mathrm{CaO}, \mathrm{K}_{2} \mathrm{O}, \mathrm{MgO}, \mathrm{Cl}^{-}, \mathrm{SO}_{4}{ }^{-}$podem eventualmente inviabilizar a utilização dos agregados reciclados para aplicações em concretos no quesito durabilidade (reação álcali agregado, expansão, etc); nas amostras estudadas os valores determinados situam-se abaixo dos limites vigentes.

A perda ao fogo $(\mathrm{PF})$, de 4 a $20 \%$ em massa, está relacionada à presença de aglomerantes e argilominerais (cerâmica de queima incompleta e solo). A soma dos teores de sílica, alumina, óxidos de ferro é inversamente proporcional à soma dos teores de $\mathrm{CaO}$ e $\mathrm{PF}$, indicando que quanto maior a proporção de rochas naturais e cerâmica, menores são os teores de aglomerantes e argilominerais.

Os agregados de Itaquera (IT-C e IT-V) apresentam curvas de separabilidade por densidade muito semelhantes e distintas de Vinhedo (VI-V), o qual que tem maior parcela de fração de material abaixo de $2,2 \mathrm{~g} / \mathrm{cm}^{3}$. Os produtos de separabilidade da fração miúda apresentam distribuições similares e independentes da origem ou classificação do RCD (cinza ou vermelho), sendo que mais de $80 \%$ em massa 
apresenta massa específica aparente acima de $2,2 \mathrm{~g} / \mathrm{cm}^{3}$. Os teores dos principais óxidos e aglomerantes são fortemente influenciados pela massa específica aparente do material, não sendo observada influência significativa da origem ou classe do RCD.

Argilominerais e produtos hidratados a base de cimento são responsáveis pelos valores mais elevados de perda ao fogo dos produtos de menores densidades. Os teores de perda ao fogo, bem como de aglomerantes, estão intrinsecamente relacionados à massa específica aparente segundo uma correlação linear inversa, fato este comprovado nas observações ao microscópio óptico.

A qualidade dos agregados pode ser avaliada em função dos valores de massa específica aparente (MEA) e absorção de água; os resultados obtidos mostram uma relação acentuada entre a massa específica aparente do agregado e propriedades físicas. Dessa forma a separação densitária pode ser uma ferramenta eficiente para controlar a qualidade dos agregados reciclados.

A massa específica determinada por picnometria de He denota que a densidade real dos grãos é pouco variável, situando-se entre 2,6 e $2,7 \mathrm{~g} / \mathrm{cm}^{3}$. As diferenças observadas entre a massa específica real e aparente estão relacionadas à porosidade, a qual aumenta com o conteúdo de aglomerantes e de argilominerais.

\subsection{CONCLUSÕES}

Os estudos realizados mostram que a utilização de agregados reciclados em concretos de alto desempenho é tecnicamente possível, desde que sejam incorporadas operações unitárias complementares de beneficiamento aos processos vigentes no país.

A distinção em classes cinza e vermelho não se mostrou seletiva do ponto de vista das propriedades caracterizadas: composição química, propriedades físicas e microestruturais; não sendo, portanto, relevante para fins da utilização como agregados reciclados. 
Contudo, a separação por densidade mostrou-se eficiente para obtenção de agregados de qualidade para uso em concretos; Carrijo (CARRIJO, 2005) obteve conclusões semelhantes quanto analisou a influência da porosidade, através de separações por densidades, na utilização de agregados reciclados para produção de concretos. As amostras estudadas apresentam uma mais que $80 \%$ com massa específica aparente superior a $2,2 \mathrm{~g} / \mathrm{cm}^{3}$ e propriedades físicas adequadas para uso em concreto estrutural.

Para comprovação dos resultados ora obtidos, sugere-se a realização de ensaios contínuos de beneficiamento mineral por processos gravíticos de concentração (jigagem), a fim de avaliar as possibilidades e parâmetros operacionais para a obtenção de agregados reciclados para uso em concretos estruturais mediante a remoção da fração de materiais de elevada porosidade, bem como dos não minerais. 


\section{REFERÊNCIAS BIBLIOGRÁFICAS}

ALAEJOS, P. G. et al. Draft of Spanish regulations for the use of recycled aggregate in the production of structural concrete. In: International Rilem Conference on the Use of Recycled Materials in Buildings and Structures. Barcelona, 2004. Proceedings. França: Elsevier Publications, 2004. v. 1. p. 511-525.

ALAEJOS, P. G.; SÁNCHEZ, M. J.. Utilization of recycled concrete aggregate for structural concrete. In: International Rilem Conference on the Use of Recycled Materials in Buildings and Structures. Barcelona, 2004. Proceedings. França: Elsevier Publications, 2004. v. 2. p. 693-702.

ALL MINERAL. Catálogo de equipamentos. Disponível em: www.allmineral.com. Acesso em nov. 2005.

ANCIA, P. et al. The use of mineral processing techniques for the improvement of the building rubble characteristics. In: Global Symposium on Recycling, Waste Treatment and Clean Technology, 1999, San Sebastián. Proceedings. Warrendale: TMS/INASMET, 1999. p. 583-598.

ANGULO, S. C. Caracterização de agregados de resíduos de construção e demolição reciclados e a influência de suas características no comportamento dos concretos. 2005. 149p. Tese (Doutorado) - Escola Politécnica, Universidade de São Paulo. São Paulo, 2005.

ANGUlO, S. C. et al. Construction and demolition waste management in Brazil. Waste Management World, London. Mar/Apr, p. 54-57, $2003 \mathrm{~b}$.

ANGUlO, S. C. et al. Construction and demolition waste, its variability and recycling in Brazil. In: International Conference on Sustainable Building, 3, 2002, Oslo. Proceedings. Noruega: [s.n.], 2002b. CD-ROM.

ANGUlO, S. C. et al. Desenvolvimento de novos mercados para a reciclagem massiva de RCD. In: Seminário de Desenvolvimento Sustentável e a Reciclagem na 
Construção Civil, 5, 2002, São Paulo. Anais: São Paulo: IBRACON/IPEN. 2002a. p. 293-307.

ANGULO, S. C. et al. Metodologia de caracterização de resíduos de construção e demolição. In: Seminário de Desenvolvimento Sustentável e a Reciclagem na Construção Civil, 6, 2003, São Paulo. Anais: IBRACON/IPEN. 2003a. CD-ROM.

ANGULO, S. C. Variabilidade de agregados graúdos de resíduos de construção e demolição reciclados. 2000. 155p. Dissertação (Mestrado) - Escola Politécnica, Universidade de São Paulo. São Paulo, 2000.

ANGULO, S. C.; JOHN, V. M. Requisitos para a execução de aterros de resíduos de construção e demolição. Câmara Ambiental da Construção. São Paulo, 2002a. 15 p. (documento interno).

ÂNGUlO, S.C., CHAVES, A.P., JOHN, V.M., ALMEIDA, S.L.M., LIMA, F.M.R.S., GOMES, P.C. Análise comparativa da tecnologia de usina na reciclagem da fração mineral dos resíduos de construção e demolição. In: XXI Encontro Nacional de Tratamento de Minérios e Metalurgia Extrativa (ENTMME), 2005, Natal. Anais. p. 305-312.

ANGULO, S.C.; MIRANDA, L.F.R.; JOHN, V.M.. Building new opportunities construction and demolition waste management in Brazil. Waste management World, London, p. 47-57, Mar/Apr 2003.

ANGULO, S.C.; JOHN, V. M. . Normalização dos agregados graúdos de resíduos de construção e demolição reciclados para concretos e a variabilidade. In: IX Encontro Nacional de Tecnologia do o Ambiente Construído, 2002, Foz do Iguaçu. ENTAC 2002. FLORIANOPOLIS : INFOHAB ANTAC NPC UFSC, 2002. p. 16131624.

BIOCYCLE. Initiating change in C\&D management, Emmaus. p. 44-48, jan. 1996. BODI, J.; BRITO FILHO, J.A.; ALMEIDA, S. Utilização de entulho de construção civil reciclado na pavimentação urbana. In: $29^{\text {a }}$ Reunião Anual de Pavimentação, Associação Brasileira de Pavimentação, Cuiabá, 1995. Anais. Cuiabá, 1995. pg 409436. 
BOSSINK,B.A.G.; BROUWERS, H.J.H. Construction waste: quantification and source evaluation. Journal of Construction Engineering and Management, n. 122, Mar., p. 55-60, 1996.

BRASIL, N. I. Introdução à Engenharia Química. Rio de Janeiro: Interciência., 2004. $2^{\mathrm{a}}$ ed. 294 p.

BREUER, H. et al. Gravity Separation of Rubble - a Contribution to the Closed Cycle of Raw Material Usage. In: International Mineral Processing Congress, 20, 1997, Aachen. Proceedings. Alemanha: GMDB, 1997. p. 445-456.

BRITO, J.A. Cidade versus entulho. Areia \& Brita, p.22-26, out/dez., 1998.

BROWING, J. S. Heavy liquids and procedures for laboratory separation of minerals. Washington: USBM, 1961. (Bureau of Mines. Information Circular, 8007).

BURT, R.O. Gravity concentration technology. Amsterdam: Elsevier, 1984. v. 5. $605 \mathrm{p}$.

CAMPOS, A.R.; LUZ, A. B. Separação em meio denso. In: LUZ, A.B. et al. Tratamento de Minérios. Rio de Janeiro: CETEM/CNPq/MCT, 1998. p. 299-337.

CARRIJO, P. M. Análise da influência da massa específica de agregados graúdos provenientes de resíduos de construção e demolição no desempenho mecânico do concreto. 2005. 129p. Dissertação (Mestrado) - Escola Politécnica, Universidade de São Paulo. São Paulo, 2005.

CHAVES, A. P. Teoria e prática do tratamento de minérios. São Paulo: Signus, 1996. v. 2. 424 p.

$\mathrm{CHEN}, \mathrm{H}$, et al. Use of building rubbles as recycled aggregates. Cement and concrete research. V. 33, pp. 125-132, 2003.

COLLINS, R. Recycled concrete. Quarry management, v. 24, n.12, p.31-36, dec., 1997.

COLLINS, R. Recycled aggregates in ready mix materials review. Concrete Engineering International, Farnham Surrey, v. 2, n. 2, p. 49-54, Mar. 1998. 
CONAMA. Resolução no 307, de 5 de julho de 2002. Conselho Nacional do Meio Ambiente, Ministério das Cidades, Secretaria Nacional da Habitação. Publicada no Diário Oficial da União em 17/07/02.

CULLITY, B. D. Elements of X-ray diffraction. 2.ed. Addison-Wesley Publishing Company, INC., 1978. 555p.

DE PAW, C. Recyclage des Descombres d'Une Ville Sinistree. CSTC, revue n.4, p.12-28. dez., 1982.

DESSY, P., et al. Analysis of the performance of concrete components made with recycled aggregates. In: CIB Building Congress - Materials and Technologies for sustainable construction. Suíca, 1998. Proceedings. Suíca, 1998. p.149-156.

DEUTSCHE INSTITUT FÜR NORMUNG (DIN). DIN 4226-100: Aggregates for Mortar and Concrete - part 100: recycled aggregates. Germany, 2002.

DIJK, K. et al. Recycling Technology in the Clay Brick Industry. In: International Conference on Sustainable Building, 3, 2002, Oslo. Proceedings. Noruega: [s.n.], 2002. CD-ROM.

ELIAS-OZKAN, S.T. Recycling rubble into aggregates: a model for local governments. Habitat International, n. 25, p. 493-502, 2001.

ENVIRONMENTAL PROTECTION AGENCY (EPA). Characterization of building-related construction and demolition debris in the United States. United States: [s.n.]. 1998. 100 p. (Report nºPA530-R-98-010).

EUROPEAN COMMISSION (EC). Management of construction and demolition waste. 2000. Disponível em: <http://europa.eu.int/comm/enterprise/environment>. Acessado em: 13 jul 2004., 2002. (DG ENV E.3).

FEDERAL HIGWAY ADMINISTRATION. Recycled materials in European highway environments: uses, technologies, and policies. United States: U. S. Department of Transportation, 2000. 94p (FHWA-PL-00-025).

FERRAZ, G.R. et al. Estações de classificação e transbordo na cidade de São Paulo. In: Seminário de Desenvolvimento Sustentável e a Reciclagem na Construção Civil, 4, 2001, São Paulo. Anais. São Paulo: IBRACON/IPEN, 2001. p.75-86. 
FORMOSO, M. L. L. Difratometria de raios-X. In: GOMES, C. B. (Coord.). Técnicas analíticas instrumentais aplicadas à geologia. São Paulo: Blucher/ Próminério, 1984. p. 1-43.

FREIRE, L.; BRITO, J. Custos e benefícios da demolição seletiva. In: Construção 2001, 2001, Lisboa. Anais. Portugal: Instituto Superior Técnico, 2001. p. 863-870.

GALLIAS, J.L. Action of gypsum on recycled aggregates concrete. In: CIB Building Congress - Materials and Technologies for Sustainable Construction. Suíca, 1998. Proceedings. Suíca, 1998. p.175-182.

GAUDIN, A. M. Principles of mineral dressing. New York: MacGraw-Hill, 1932. $554 \mathrm{p}$.

GAVILAN, R.M.; BERNOLD, L.E. Source evaluation of Solid Waste in Building Construction. Journal of Construction Engineering and Management, n. 120, p.536552, Dec., 1994.

GOLDSTEIN, J. et al. Scanning Electron Microscopy and X-ray Microanalysis. New York, 2003. $3^{\text {a }}$ ed. 689 p.

GOMES, C.B. Técnicas Analíticas Instrumentais Aplicadas à Geologia. São Paulo. 1984. Ed. Edgar Blucher: Prominério.

GRIGOLI, A.S. Management in the production and utilization of the waste material in the construction site. CIB Symposium on construction \& environment: theory into practice. Global Seven Editora Ltda.São Paulo, 2000.

GRUBL, P.; RUHL, M. German Committee for Reinforced Concrete (DafStb) Code: Concrete with recycled aggregates. 1998. Disponível em: http://www.b-im.de/public/tudmassiv/dundeegrueblruehl.htm. Acessado em: Julho de 2002.

HANISCH, J. Current developments in the sorting of building waste. Aufbereitungstechnik. v. 39, n. 10, 1998.

HANSEN, T.C. Rilem report 6 - Recycling of Demolished Concrete and Masonry. London: E\& FN SPON/Chapman \& Hall, 1992. 305p. 
HARDER, M.K.; FREEMAN, L.A. Analysis of the volume and composition of construction waste arriving at landfill. In: International Conference on Building and the Environment, 2, 1997, Paris. Proceedings. Paris: CSTB, 1997. p. 595-602.

HENDRIKS, C. F. A new vision on the building cycle. Holanda: Aeneas, 2004. 251 p.

HENDRIKS, C.F. The building cycle. Holanda: Aeneas, 2000. 231 p.

HENDRIKS, C.F.; JANSSEN, G. M. T. Application of construction and demolition waste. Heron, v. 46, n. 2 , p. 79-88, 2001.

HOBBS, G.; HURLEY, J. Deconstruction and reuse of construction materials. In: CHINI, A.R. Deconstruction and material reuse: technology, economy and policy. Florida: CIB, 2001. p. 98-124. (Publication 266).

HONG KONG POLYTECHNIC. The Hong Kong Construction Association. Reduction of Construction Waste - final report. Hong Kong, s.ed., March 1993.

INBRAS - ERIEZ EQUIPAMENTOS MAGNÉTICOS E VIBRATÓRIOS LTDA. Catálogo de equipamentos. Disponível em http://www.inbras.com.br. Acessado em: Jul., 2006.

INNER SIDNEY WASTE BOARD (ISWB). A draft specification for supply of recycled material for roads, drainage and fills. 2001. Disponível em: wasteboards.nsw.gov.au/construction/default.htm. Acessado em: Jan., 2003.

INSTITUT DE TECNOLOGIA DE LA CONSTRUCCIÓ DE CATALUNYA-ITEC. Manual de desconstrucció. ITEC \& Generalitat de Catalunya, Departament de Medi Ambient, Junta de Resius. Catalunha, Espanha, novembre 1995c.

INTERNATIONALE VEREINIGUNG BAUSTOFF-RECYCLING - IVBR. Bauschutt-recycling in Europa. Bonn, [1995]. s.n.t.

JAPAN BUILDING CONTRACTORS SOCIETY OF JAPAN B.C.S.J. - Proposed standard for the use of recycled aggregate concrete Committee on Disposal and Reuse of Construction Waste, 1997. 
JOHN, V. M.; ANGULO, S. C. Metodologia para o desenvolvimento de reciclagem de resíduos. In: JOHN, V. M.; ROCHA, J. C. Utilização de resíduos na Construção Habitacional. Porto Alegre: ANTAC, 2003. v.4. p. 8-71.

JOHN, V.M. Reciclagem de resíduos na construção civil - contribuição à metodologia de pesquisa e desenvolvimento. 2000. 102p. Tese (livre docência) Escola Politécnica, Universidade de São Paulo. São Paulo, 2000.

JOHN, V.M.; AGOPYAN, V. Reciclagem de resíduos da construção. In: Seminário - Reciclagem de Resíduos Sólidos Domiciliares, 2000, São Paulo. Anais. São Paulo: CETESB, 2000. CD-ROM.

JONES, M. P. Applied mineralogy - a quantitative approach. United States: Graham \& Trotman, 1987.259p.

JUNGMANN, A et al. Building Rubble Treatment using Alljig in Europe and USA. Aufbereitungs-technik. v. 38, n. 10, p. 543-549, 1997.

JUNGMANN, A.; QUINDT, J. Alljig - technology for separation of building rubble and other secondary raw materials. In: Global Symposium on Recycling, Waste Treatment and Clean Technology, 1999, San Sebastian. Proceedings. Warrendale: TMS/NASMET, 1999. p. 367-379.

KAHN, H. Caracterização de matérias-primas minerais associadas a complexos alcalino-carbonatíticos. 1999. 216p. Tese (livre docência) - Escola Politécnica, Universidade de São Paulo. São Paulo, 1999.

KELLY, E. C.; SPOTTISWOOD, J. Introduction to mineral processing. New York: John Willey, 1982. 492p.

KIBERT, C. J.; CHINI, A. R. Deconstruction as an essential component of sustainable construction. In: KIBERT, C.J.; CHINI, A.R. Deconstruction and material reuse: technology, economy and policy. Florida: CIB, 2000. p.6-13. (CIB Publication 252).

KLEIN, C.; HURBURT, C. S. Manual of mineralogy. New York: John Willey, 1993. 
KOHLER, G.; KURKOWSKI, H. Optimizing the use of RCA. 2000. Disponível em: www.b-im.de/public/deutag_remex/kohlerkurkowski.htm. Acessado em: Jan. 2003.. KOHLER, G.; PENZEL, U. State-of-art development of demolition rubble recycling aimed to high-grade application. Aufbereitungs technik. v. 38, n. 3, p. 119-29, 1997. KOWALCZYK, T et al. State of art deconstruction in Netherlands. In: KIBERT, C.J.; CHINI, A.R. Deconstruction and material reuse: technology, economy and policy. Florida: CIB, 2000. p. 95-129. (CIB Publication 252).

LAURITZEN, K. E. RILEM Bulletin - International RILEM symposium on demolition and reuse of concrete and masonry. Materials and Structures, Paris, n. 27, p. 307-330, 1994.

LEAL, U. Sobras que valem um obra. Téchne. n. 55 p. 58-62 outubro, 1999. PINI. São Paulo.

LEVY, S.M. Reciclagem do entulho de construção civil, para utilização como agregado de argamassas e concretos. São Paulo, 1997a. 147p. Dissertação (Mestrado). Escola Politécnica, Universidade de São Paulo.

LIMA, J.A.R. Proposição de diretrizes para a produção e normalização de resíduo de construção reciclado e de suas aplicações em argamassas e concretos. 1999. 204p. Dissertação (Mestrado) - Escola de Engenharia de São Carlos, Universidade de São Paulo. São Carlos, 1999.

LUZ, A.B. et al. Tratamento de minérios. 2. ed. Rio de Janeiro: CETEM/CNPq/MCT, 1998. 676p.

MESTERS, K.; KURKOMSKI, H. Density separation of recycling building materials by means of jig technology. Aufbereitungs technik, n. 38, p. 536-542, 1997. MILANI, B. Clean-up is more difficult than dumping. Environmental Technology form Switzerland . Zurich. Swiss Association of Machinery Manufacturers. p. 55-59. nov., 1990.

MIRANDA, L. F. R. Estudo de fatores que influem na fissuração de revestimentos de argamassa com entulho reciclado. Dissertação (Mestrado). Escola Politécnica, Universidade de São Paulo. São Paulo, 2000. 172p. 
MOSKALA, R.; SCHNEIDER-KÜHN, U. Wet processing, the indispensable alternative for processing of demolition debris. In: International Mineral Processing Congress, 20, 1997, Aachen. Proceedings. Alemanha: GMDB, 1997. p. 471-478.

MULDER, E. et al. Closed materials cycles for concrete and masonry, as part of an integrated process for the reuse of the total flow of $C \& D$ waste. In: International Conference on the Environmental and Technical Implications with Alternative Materials, 5, 2003, San Sebastian. Proceedings. Espanha: ISCOWA/INASMET, 2003. p. 219-229.

MULDER, E. Re-use of sieve sand from demolition waste. In: International Conference on the Environmental and Technical Implications with Alternative Materials, 3, 1997, Leeds. Proceedings. Amsterdam: Elsevier, 1997. p. 699-704.

MÜLLER, A. Recycling von Mauerwerkbruch - stand und neue verwertungswege (teil 1). Ziegelindustrie International. v. 56, n. 6, p. 17-25, 2003.

MÜLLER, A.; LINSZ, E. Processing of concrete with high performance sonic impulses. In: International Rilem Conference on the Use of Recycled Materials in Buildings and Structures, 2004, Barcelona. Proceedings. França: Elsevier publications, 2004. v. 1. p. 123-132.

NORDBERG NEWS. Helsinki, v.2, n. 90, s.d.

O'ROURKE, A. Recycling of construction waste - barriers to success. In: International Conference on Sustainable Building, 3, 2002, Oslo. Proceedings. Noruega: [s.n.], 2002. CD-ROM.

OLIVEIRA M. J. E. de, ASSIS C. S. Estudo da deterioração de concreto proveniente de demolição de obras de construção civil e seu comportamento em relação ao meio ambiente. In: $41^{\circ}$ Congresso de concreto. Salvador, 1999. Ibracon (em CD-ROM).

OLIVEIRA, M. J. E. de; ASSIS, C. S. de; TERNI, A. V. Study on compressed stress, water absorption and modulus of elasticity of produced concrete made by recycled aggregate. International RILEM Conference on the use of recycled materials in buildings and structures. Espanha, 2004. p. 636-342. 
PARFENOFF,A.; POMEROL,C.; TOURENQ,J. Les mineraux en grains; méthods d'étude et détermination. Paris. 1970. 578p. 6ed.

PELLETIERE, D. The economics of downcycling: an overview with illustration from the international used car trade. 2001. Disponível em: www.is4ie.org/images/Pelletiere_paper.pdf. Acessado em: 15 novembro de 2004.

PENG, C., et al. Strategies for successful construction and demolition waste recycling operations. Construction, Management and Economics, London, n. 15, p. 49-58, 1997.

PERA, J. State of the art report: use of waste materials in construction in Western Europe. In: Seminário sobre Reciclagem e Reutilização de Resíduos como Materiais de Construção, 1996, São Paulo. Anais. São Paulo: EP-USP, 1996. p.1-20.

PICCHI, F.A. Sistemas de Qualidade: uso em empresas de construção de edifícios. São Paulo, 1993. Tese (Doutorado). Escola Politécnica, Universidade de São Paulo.

PINTO, T. P. Perda de materiais em processos construtivos tradicionais. São Carlos: Departamento de Engenharia Civil da Universidade Federal de São Carlos (Texto datilografado), 1989. $33 \mathrm{p}$.

PINTO, T.P. De volta à questão do desperdício. Construção. São Paulo : Pini, n. 2491, p. 18-19, nov. 1995.

PINTO, T.P. Metodologia para a gestão diferenciada de resíduos sólidos da construção urbana. 1999. 189p. Tese (Doutorado) - Escola Politécnica, Universidade de São Paulo. São Paulo, 1999.

PINTO, T.P. Utilização de resíduos de construção. Estudo do uso em argamassas. 1986. 137p. Dissertação (Mestrado) - Escola de Engenharia de S'ao Carlos, Universidade de São Paulo. São Carlos, 1986.

POON, C. S. et al. On-site sorting of construction and demolition waste in Hong Kong. Resources, conservation and recycling. n. 32, p. 157-172, 2001.

QUARCIONI, V. et al. Proposta de método para determinação de sais solúveis em argamassas endurecidas. In: Simpósio Brasileiro de Tecnologia das Argamassas, 5, 2003, São Paulo. Anais. São Paulo: ANTAC, 2003. p. 647-662. 
QUEENSLAND. Construction and demolition waste - waste management and resource use opportunities. 2003. 52 p. Disponível em: $<$ http://www.epa.qld.gov.au>. Acessado em: Out., 012003.

REID, J. M. Alternative materials in construction: UK experience. In: International Conference on the Environmental and Technical Implications with Alternative Materials, 5, 2003, San Sebastian. Proceedings. Espanha: ISCOWA/INASMET, 2003. p. 743-752.

RILEM RECOMMENDATION. Specification for concrete with recycled aggregates. Materials and Structures, n.27, p.557-59, 1994.

RUCH, M. et al. Selective dismantling of buildings: state of the art and new developments in Europe. In: International Conference on Building and the Environment, 2, 1997, Paris. Proceedings. Paris: CSTB, 1997. p.433-40.

SANT'AGOSTINHO, L.M; KAHN, H. Metodologia para Caracterização Tecnológica de Matérias Primas Minerais. São Paulo: Boletim técnico (Escola Politécnica), Universidade de São Paulo, 1997. 29p.

SCHNEIDER, D. M. Transporte de resíduos de construção e demolição na cidade de São Paulo. 2003. 103p. Dissertação (Mestrado) - Faculdade de Saúde Pública, Universidade de São Paulo. São Paulo, 2003.

SCHULTMANN, F. et al. Methodologies and guidelines for deconstruction in Germany and France. In: CHINI, A. R. Deconstruction and material reuse: technology, economy and policy. Florida: CIB, 2001. p. 27-43. (CIB Publication 266).

SCHULTMANN, F. et al. Strategies for quality improvement of recycling materials. In: INTERNATIONAL CONFERENCE ON BUILDING AND THE ENVIRONMENT, 2, 1997, Paris. Proceedings. Paris: CSTB, 1997. p.611-18.

SCHULTMANN, F.; RENTZ, O. The state of deconstruction in Germany. In: KIBERT, C.J.; CHINI, A.R. Deconstruction and material reuse: technology, economy and policy. Florida: CIB, 2000. p. 45-69. (CIB Publication 252).

SINDICATO DA INDÚSTRIA DA CONSTRUÇÃO DO ESTADO DE SÃO PAULO (SINDUSCON-SP). Gestão ambiental de resíduos da construção civil: a 
experiência do SINDUSCON-SP. PINTO, T. P. et al. São Paulo: Obra Limpa/I\&T/SINDUSCON-SP, 2005. 48 p.

SMITH, M.R.; COLLIS, L. Aggregates - sand, gravel and crushed rock aggregates for construction purposes. 2 ed. London: The Geological Society, 1993. 339 p.

SOILBELMAN, L. As perdas de materiais na construção de edificações: sua incidência e seu controle. Porto Alegre, 1993 127p. Dissertação (Mestrado). Escola de Engenharia da Universidade Federal do Rio Grande do Sul.

SOUZA, U.B.L. et al., Perdas de materiais nos canteiros de obras: a quebra do mito. Qualidade na Construção, v.2, n.13, p.10 -15, 1998.

SUZUKI, M. Recycling for construction and demolition wastes in Japan. In: International Mineral Processing Congress, 20, 1997, Aachen. Proceedings. Alemanha: GMDB, 1997. p. 457-469.

SYMONDS. Construction and demolition waste management practices and their economic impact. 1999. Disponível em: <http://europe.eu.int/comm/environment>. Acessado em: Nov. 2002.

THOLE. Pre-separation units. Disponível em: $<$ http://www.thole.nl/products/engels/bt_engl.htm>. Acessado em : Nov. 2002.

TOMAS, J. et al. Impact crushing of concrete for liberation and recycling. In: INTERNATIONAL MINERAL PROCESSING CONGRESS, 20, 1997, Aachen. Proceedings. Alemanha: GMDB, 1997. p. 433-444.

TOMAS, J. et al. Liberation and separation of valuables from building material waste. In: Global Symposium on Recycling, Waste Treatment and Clean Technology, 1999, San Sebastián. Proceedings. Warrendale: TMS/INASMET, 1999. p.461-471.

TRANKLER, J. O. V et al. Environmental impact of demolition waste - an overview on 10 years of research and experience. Waste management, v. 16, n. 3, p. 21-26, 1996.

ULSEN, C. et al. Applied Mineralogy characterization of construction and demolition waste from Brazilian recycling plants. In: International Congress on 
Applied Mineralogy, 8, 2004, Àguas de Lindóia. Proceedings. São Paulo: ICAM, 2004. p. 763-766.

VÁZQUEZ, E.; BARRA, M. Recycling of aggregates in the construction industry. CIB Symposium on Construction \& Environment: theory into practice. Global Seven Editora Ltda. São Paulo, 2000.

WAHLSTRÖM, M. et al. Environmental quality assurance for use of crushed mineral demolition wastes in earth constructions. In: Waste Materials in Construction: putting theory into practice, 1997, Leeds. Proceedings. Amsterdan: Elsevier, 1997. p. 725-34.

WILLIAMS, C. T. Analysis of rare earth minerals. In: JONES, A.P.; WALL, F e WILLIAMS, T., eds. Rare Earth Minerals: chemistry, origin and ore deposits. Ed.; London, Chapman \& Hall, 1996. Cap. 13, p. 327-348. (The Mineralogical Society Series, 7).

WILSON, J. Recycling Construction and Demolition Waste: the Dutch experience. Quarry Management. v. 23, n. 12, 1996. p. 29-36.

XING, W. et al. Closing the cycle of building materials - recycling of construction and demolition waste by quality improvement. In: International Conference on Sustainable Building, 3, 2002, Oslo. Proceedings. Noruega: [s.n.], 2002. CD-ROM.

YOST, P. C\&D/Wood debris management trends. Resource Recycling, Portland, p. 22-28. Nov. 1998.

ZORDAN, S.E. A utilização do entulho como agregado, na confecção do concreto. Campinas. 1997. 140p. Dissertação (Mestrado) - Faculdade de Engenharia Civil, Universidade de Campinas. Campinas, 1997. 


\section{APÊNDICE - TABELAS DE COMPOSIÇÃO}

QUÍMICA

Tabela 1 - Composição granuloquímica do agregado reciclado de Itaquera, tipo cinza (IT-C)

\begin{tabular}{|c|c|c|c|c|c|c|c|c|c|c|c|c|c|}
\hline \multirow{2}{*}{$\begin{array}{c}\text { Fração } \\
(\mathrm{mm})\end{array}$} & \multicolumn{2}{|c|}{$\%$ Massa } & \multicolumn{11}{|c|}{ Teores (\%) } \\
\hline & Ensaio & Acumul. & $\mathrm{SiO}_{2}$ & $\mathrm{Al}_{2} \mathrm{O}_{3}$ & $\mathrm{Fe}_{2} \mathrm{O}_{3}$ & $\mathrm{CaO}$ & $\mathrm{MgO}$ & $\mathrm{Na}_{2} \mathrm{O}$ & $\mathrm{K}_{2} \mathrm{O}$ & $\mathrm{TiO}_{2}$ & $\mathrm{P}_{2} \mathrm{O}_{5}$ & $\mathrm{SO}_{3}$ & PF \\
\hline$-25,4+19,1$ & 15,8 & 15,8 & 65,1 & 9,24 & 3,14 & 9,13 & 1,39 & 1,47 & 2,58 & 0,49 & 0,15 & 0,14 & 7,20 \\
\hline$-19,1+12,7$ & 21,8 & 37,6 & 65,6 & 8,89 & 3,22 & 9,21 & 1,41 & 1,38 & 2,36 & 2,36 & 0,15 & 0,28 & 7,16 \\
\hline$-12,7+9,5$ & 9,2 & 46,9 & 67,9 & 8,45 & 2,63 & 8,40 & 1,15 & 1,44 & 2,61 & 2,61 & $\ldots$ & 0,20 & 8,15 \\
\hline$-9,5+4,8$ & 14,0 & 60,9 & 66,1 & 9,28 & 2,71 & 8,68 & 1,27 & 1,32 & 2,62 & 2,62 & 0,14 & 0,24 & 8,22 \\
\hline$-4,8+2,4$ & 9,2 & 70,1 & 66,5 & 8,70 & 2,61 & 8,71 & 1,14 & 1,19 & 2,54 & 2,54 & $\ldots$ & 0,23 & 9,01 \\
\hline$-2,4+1,2$ & 7,5 & 77,6 & 67,7 & 8,14 & 2,45 & 8,18 & 1,06 & 1,00 & 2,42 & 2,42 & $\ldots$ & 0,20 & 8,40 \\
\hline$-1,2+0,6$ & 7,1 & 84,7 & 71,5 & 7,03 & 2,16 & 7,27 & 0,87 & 0,60 & 2,11 & 2,11 & $\ldots$ & $\ldots$ & 6,93 \\
\hline$-0,6+0,3$ & 6,2 & 90,9 & 75,7 & 5,75 & 2,00 & 6,01 & 0,69 & 0,37 & 1,63 & 1,63 & $\ldots$ & $\ldots$ & 7,84 \\
\hline$-0,3+0,15$ & 4,8 & 95,8 & 68,5 & 7,21 & 2,61 & 7,81 & 0,98 & 0,38 & 1,67 & 1,67 & $\ldots$ & $\ldots$ & 10,0 \\
\hline$-0,15$ & 4,2 & 100,0 & 48,0 & 10,8 & 3,50 & 13,9 & 1,79 & 0,48 & 1,81 & 1,81 & 0,18 & 0,33 & 19,6 \\
\hline Total & 100,0 & & 66,5 & 8,56 & 2,80 & 8,72 & 1,22 & 1,14 & 2,35 & 2,02 & 0,08 & 0,18 & 8,36 \\
\hline
\end{tabular}

Tabela 2 - Composição granuloquímica do agregado reciclado de Itaquera, tipo vermelho (IT-V)

\begin{tabular}{|c|cc|cccccccccccc|}
\hline $\begin{array}{c}\text { Fração } \\
\text { (mm) }\end{array}$ & $\begin{array}{c}\text { \% Massa } \\
\text { Ensaio }\end{array}$ & \multicolumn{1}{|c|}{ Acumul. } & $\mathrm{SiO}_{2}$ & $\mathrm{Al}_{2} \mathrm{O}_{3}$ & $\mathrm{Fe}_{2} \mathrm{O}_{3}$ & $\mathrm{CaO}$ & $\mathrm{MgO}$ & $\mathrm{Na}_{2} \mathrm{O}$ & $\mathrm{K}_{2} \mathrm{O}$ & $\mathrm{TiO}_{2}$ & $\mathrm{P}_{2} \mathrm{O}_{5}$ & $\mathrm{SO}_{3}$ & $\mathrm{PF}$ \\
\hline$-25,4+19,1$ & 6,8 & 6,8 & 68,4 & 11,2 & 3,30 & 5,76 & 0,95 & 1,68 & 3,22 & 0,42 & $\ldots$ & 0,17 & 4,94 \\
$-19,1+12,7$ & 12,5 & 19,3 & 68,6 & 10,2 & 3,28 & 6,49 & 1,18 & 1,57 & 2,82 & 0,41 & $\ldots$ & 0,27 & 4,56 \\
$-12,7+9,5$ & 11,7 & 31,1 & 65,3 & 10,1 & 3,32 & 8,18 & 1,58 & 1,36 & 2,62 & 0,41 & 0,12 & 0,25 & 7,03 \\
$-9,5+4,8$ & 17,0 & 48,1 & 65,6 & 9,26 & 3,25 & 8,76 & 1,16 & 0,88 & 2,70 & 0,47 & 0,10 & 0,25 & 7,55 \\
$-4,8+2,4$ & 11,9 & 59,9 & 66,9 & 8,72 & 2,66 & 8,91 & 1,32 & 0,93 & 2,52 & 0,36 & $\ldots$ & $\ldots$ & 7,83 \\
$-2,4+1,2$ & 9,6 & 69,5 & 68,7 & 8,62 & 3,12 & 6,76 & 0,86 & 0,50 & 2,26 & 0,47 & $\ldots$ & 0,25 & 7,91 \\
$-1,2+0,6$ & 10,3 & 79,9 & 71,6 & 7,58 & 2,77 & 5,28 & 0,80 & 0,29 & 1,60 & 0,40 & $\ldots$ & $\ldots$ & 7,50 \\
$-0,6+0,3$ & 8,6 & 88,5 & 71,6 & 7,36 & 2,97 & 5,22 & 0,80 & 0,24 & 1,50 & 0,42 & $\ldots$ & $\ldots$ & 7,85 \\
$-0,3+0,15$ & 6,6 & 95,1 & 65,7 & 9,54 & 3,28 & 6,66 & 1,09 & 0,34 & 1,75 & 0,67 & $\ldots$ & $\ldots$ & 9,40 \\
$-0,15$ & 5,0 & 100,0 & 48,3 & 12,9 & 4,27 & 11,1 & 1,77 & 0,50 & 1,88 & 0,79 & 0,15 & $\ldots$ & 19,2 \\
& & & & & & & & & & & & & \\
Total & 100,0 & & 66,9 & 9,34 & 3,16 & 7,34 & 1,15 & 0,88 & 2,36 & 0,46 & $\ldots$ & $\ldots$ & 7,72 \\
\hline
\end{tabular}


Tabela 3 - Composição granuloquímica do agregado reciclado de Vinhedo, tipo vermelho (VI-V)

\begin{tabular}{|c|c|c|c|c|c|c|c|c|c|c|c|c|c|}
\hline \multirow{2}{*}{$\begin{array}{c}\text { Fração } \\
\text { (mm) }\end{array}$} & \multicolumn{2}{|c|}{$\%$ Massa } & \multicolumn{11}{|c|}{ Teores (\%) } \\
\hline & Ensaio & Acumul. & $\mathrm{SiO}_{2}$ & $\mathrm{Al}_{2} \mathrm{O}_{3}$ & $\mathrm{Fe}_{2} \mathrm{O}_{3}$ & $\mathrm{CaO}$ & $\mathrm{MgO}$ & $\mathrm{Na}_{2} \mathrm{O}$ & $\mathrm{K}_{2} \mathrm{O}$ & $\mathrm{TiO}_{2}$ & $\mathrm{P}_{2} \mathrm{O}_{5}$ & $\mathrm{SO}_{3}$ & PF \\
\hline$-25,4+19,1$ & 16,0 & 16,0 & 66,1 & 9,92 & 2,78 & 9,08 & 1,41 & 0,97 & 2,15 & 0,47 & $\ldots$ & 0,38 & 7,09 \\
\hline$-19,1+12,7$ & 27,3 & 43,3 & 69,4 & 10,1 & 3,37 & 5,20 & 1,11 & 0,77 & 2,32 & 0,56 & $\ldots$ & 0,22 & 5,70 \\
\hline$-12,7+9,5$ & 7,7 & 51,0 & 69,4 & 11,1 & 3,36 & 7,15 & 1,11 & 0,90 & 2,32 & 0,44 & $\ldots$ & 0,62 & 7,48 \\
\hline$-9,5+4,8$ & 9,4 & 60,4 & 67,6 & 9,57 & 2,77 & 6,85 & 1,29 & 1,18 & 2,28 & 0,50 & $\ldots$ & 0,30 & 6,76 \\
\hline$-4,8+2,4$ & 5,7 & 66,1 & 68,4 & 10,4 & 3,40 & 6,20 & 1,18 & 0,79 & 1,99 & 0,52 & $\ldots$ & 0,28 & 6,33 \\
\hline$-2,4+1,2$ & 4,9 & 71,0 & 76,8 & 7,92 & 2,75 & 4,10 & 0,69 & 0,51 & 1,61 & 0,39 & $\ldots$ & 0,16 & 5,07 \\
\hline$-1,2+0,6$ & 5,6 & 76,5 & 83,7 & 5,42 & 2,23 & 2,58 & 0,42 & 0,22 & 1,17 & 0,24 & $\ldots$ & $\ldots$ & 3,35 \\
\hline$-0,6+0,3$ & 5,4 & 82,0 & 84,2 & 4,66 & 2,14 & 2,41 & 0,39 & 0,16 & 1,12 & 0,25 & $\ldots$ & $\ldots$ & 3,86 \\
\hline$-0,3+0,15$ & 6,7 & 88,7 & 81,4 & 5,53 & 2,30 & 2,98 & 0,50 & 0,19 & 1,24 & 0,41 & $\ldots$ & 0,12 & 4,30 \\
\hline$-0,15$ & 11,3 & 100,0 & 52,2 & 15,9 & 4,71 & 7,82 & 1,37 & 0,29 & 1,99 & 0,88 & 0,18 & 0,37 & 13,9 \\
\hline Total & 100,0 & & 69,5 & 9,81 & 3,14 & 5,98 & 1,07 & 0,68 & 1,99 & 0,51 & $\ldots$ & $\ldots$ & 6,76 \\
\hline
\end{tabular}


Tabela 4 - Composição química por faixa de densidade do agregado reciclado de Itaquera, tipo cinza (IT-C)

\begin{tabular}{|c|c|c|c|c|c|c|c|c|c|c|c|c|c|}
\hline \multirow{2}{*}{$\begin{array}{c}\text { Produto/ } \\
\text { Fração }(\mathrm{mm})\end{array}$} & \multicolumn{2}{|c|}{$\%$ Massa } & \multicolumn{11}{|c|}{ Teores (\%) } \\
\hline & Ensaio & Amostra & $\mathrm{SiO}_{2}$ & $\mathrm{Al}_{2} \mathrm{O}_{3}$ & $\mathrm{Fe}_{2} \mathrm{O}_{3}$ & $\mathrm{CaO}$ & $\mathrm{MgO}$ & $\mathrm{Na}_{2} \mathrm{O}$ & $\mathrm{K}_{2} \mathrm{O}$ & $\mathrm{TiO}_{2}$ & $\mathrm{P}_{2} \mathrm{O}_{5}$ & $\mathrm{SO}_{3}$ & PF \\
\hline$-25,4+19,1$ & & & & & & & & & & & & & \\
\hline$d<1,7$ & 0,6 & 0,1 & $\ldots$ & $\ldots$ & $\ldots$ & $\ldots$ & $\ldots$ & $\ldots$ & $\ldots$ & $\ldots$ & $\ldots$ & $\ldots$ & $\ldots$ \\
\hline $1,7<d<1,9$ & 1,9 & 0,3 & 60,2 & 8,45 & 3,37 & 7,61 & 1,44 & 0,83 & 1,86 & 0,35 & 0,12 & 0,25 & 15,9 \\
\hline $1,9<d<2,2$ & 32,5 & 5,1 & 65,1 & 6,86 & 2,05 & 9,90 & 1,18 & 0,65 & 1,91 & 0,28 & $<0,10$ & 0,37 & 10,9 \\
\hline $2,2<d<2,5$ & 36,2 & 5,7 & 63,9 & 10,2 & 2,81 & 8,36 & 1,51 & 1,69 & 2,92 & 0,41 & 0,13 & 0,31 & 7,92 \\
\hline$d>2,5$ & 28,9 & 4,6 & 62,3 & 13,8 & 5,43 & 5,37 & 1,64 & 2,84 & 3,33 & 0,75 & 0,26 & 0,17 & 3,48 \\
\hline $\begin{array}{c}\text { Total } \\
-19,1+12,7\end{array}$ & 100,0 & 15,8 & 63,4 & 10,1 & 3,31 & 7,93 & 1,43 & 1,66 & 2,67 & 0,46 & $\ldots$ & 0,29 & 7,71 \\
\hline$d<1,7$ & 0,4 & 0,1 & $\ldots$ & $\ldots$ & $\ldots$ & $\ldots$ & & & & & & & $\ldots$ \\
\hline $1,7<d<1,9$ & 4,0 & 0,9 & 44,4 & 5,30 & 2,14 & 18,3 & 2,63 & 0,87 & 0,97 & 0,24 & 2,38 & 0,41 & 23,2 \\
\hline $1,9<\mathrm{d}<2,2$ & 34,1 & 7,4 & 64.5 & 5.82 & 1.79 & 10.9 & 1.53 & 0.52 & 1.66 & 0.26 & $<0,10$ & 0.43 & 12.0 \\
\hline $2,2<d<2,5$ & 33,2 & 7,2 & 67,8 & 8,75 & 3,07 & 7,29 & 1,03 & 1,61 & 2,33 & 0,42 & 0,14 & 0,27 & 7,22 \\
\hline$d>2,5$ & 28,4 & 6,2 & 61,5 & 13,2 & 4,57 & 6,16 & 1,47 & 2,97 & 3,47 & 0,65 & 0,31 & 0,15 & 4,49 \\
\hline $\begin{array}{c}\text { Total } \\
-12,7+9,5\end{array}$ & 100,0 & 21,8 & 57,3 & 12,0 & 3,80 & 7,06 & 1,42 & 1,75 & 2,32 & 0,59 & 0,27 & $\ldots$ & 13,0 \\
\hline$d<1,7$ & 0,2 & 0,0 & $\ldots$ & $\ldots$ & $\ldots$ & $\ldots$ & $\ldots$ & $\ldots$ & $\ldots$ & $\ldots$ & $\ldots$ & $\ldots$ & $\ldots$ \\
\hline $1,7<d<1,9$ & 1,1 & 0,1 & 45,8 & 15,0 & 4,10 & 6,35 & 1,63 & 0,98 & 1,53 & 0,76 & 0,12 & $<0,10$ & 24,7 \\
\hline $1,9<d<2,2$ & 11,1 & 1,0 & 58,0 & 7,72 & 2,72 & 11,1 & 1,84 & 0,53 & 1,67 & 0,38 & $<0,10$ & 0,44 & 14,9 \\
\hline $2,2<d<2,5$ & 53,1 & 4,9 & 65,5 & 7,76 & 2,53 & 8,66 & 1,26 & 1,15 & 2,12 & 0,31 & 0,10 & 0,46 & 9,65 \\
\hline$d>2,5$ & 34,6 & 3,2 & 64,5 & 13,3 & 4,19 & 4,81 & 1,16 & 2,96 & 3,96 & 0,61 & 0,21 & 0,13 & 3,38 \\
\hline $\begin{array}{c}\text { Total } \\
-9,5+4,8\end{array}$ & 100,0 & 9,2 & 64,0 & 9,74 & 3,14 & 7,56 & 1,29 & 1,70 & 2,70 & 0,43 & $\ldots$ & $\ldots$ & 8,21 \\
\hline$d<1,7$ & 0,3 & 0,0 & $\ldots$ & $\ldots$ & $\ldots$ & $\ldots$ & $\ldots$ & $\ldots$ & $\ldots$ & $\ldots$ & $\ldots$ & $\ldots$ & $\ldots$ \\
\hline $1,7<d<1,9$ & 1,1 & 0,1 & 28,5 & 7,14 & 2,52 & 10,8 & 1,39 & 1,42 & 0,72 & 0,40 & $<0,10$ & 7,37 & 40,3 \\
\hline $1,9<d<2,2$ & 13,5 & 1,9 & 60,8 & 6,87 & 2,18 & 11,6 & 1,15 & 0,63 & 1,42 & 0,33 & $<0,10$ & 0,52 & 13,5 \\
\hline $2,2<d<2,5$ & 50,9 & 7,1 & 66,6 & 7,28 & 1,78 & 9,04 & 1,04 & 0,93 & 2,02 & 0,28 & $<0,10$ & 0,36 & 10,0 \\
\hline$d>2,5$ & 34,3 & 4,8 & 62,4 & 13,0 & 3,86 & 5,79 & 1,52 & 2,79 & 3,90 & 0,48 & 0,19 & 0,18 & 5,48 \\
\hline $\begin{array}{c}\text { Total } \\
-4,8+1,2\end{array}$ & 100,0 & 14,0 & 63,8 & 9,16 & 2,55 & 8,27 & 1,22 & 1,53 & 2,56 & 0,36 & $\ldots$ & 0,39 & 9,22 \\
\hline$d<1,7$ & 0,4 & 0,1 & $\ldots$ & $\ldots$ & $\ldots$ & $\ldots$ & $\ldots$ & $\ldots$ & $\ldots$ & $\ldots$ & $\ldots$ & $\ldots$ & $\ldots$ \\
\hline $1,7<d<1,9$ & 1,2 & 0,2 & 46,5 & 8,23 & 3,76 & 11,0 & 1,66 & 1,46 & 1,49 & 0,89 & 0,17 & 0,41 & 23,1 \\
\hline $1,9<d<2,2$ & 12,8 & 2,1 & 57,2 & 8,68 & 2,32 & 10,7 & 1,21 & 0,70 & 1,70 & 0,43 & $<0,10$ & 0,56 & 15,2 \\
\hline $2,2<d<2,5$ & 59,0 & 9,9 & 68,6 & 6,96 & 1,85 & 7,20 & 0,88 & 0,85 & 2,31 & 0,25 & $<0,10$ & 0,31 & 9,64 \\
\hline$d>2,5$ & 26,6 & 4,4 & 73,0 & 10,4 & 3,81 & 3,41 & 0,98 & 2,20 & 2,62 & 0,40 & 0,16 & 0,10 & 2,89 \\
\hline $\begin{array}{c}\text { Total } \\
-1,2+0,3\end{array}$ & 100,0 & 16,8 & 67,8 & 8,08 & 2,44 & 6,66 & 0,95 & 1,19 & 2,29 & 0,32 & $\ldots$ & 0,29 & 8,68 \\
\hline$d<1,7$ & 0,2 & 0,0 & $\ldots$ & $\ldots$ & $\ldots$ & $\ldots$ & $\ldots$ & $\ldots$ & $\ldots$ & $\ldots$ & $\ldots$ & $\ldots$ & $\ldots$ \\
\hline $1,7<\mathrm{d}<1,9$ & 1,0 & 0,1 & 41,2 & 14,2 & 9,08 & 5,04 & 1,42 & 2,87 & 1,57 & 1,29 & 0,30 & 0,16 & 21,8 \\
\hline $1,9<d<2,2$ & 2,4 & 0,3 & 38,6 & 16,5 & 4,75 & 8,56 & 1,64 & 1,84 & 1,23 & 0,88 & 0,19 & 0,26 & 24,7 \\
\hline $2,2<d<2,5$ & 31,6 & 4,2 & 63,7 & 8,76 & 2,29 & 7,37 & 1,02 & 1,06 & 3,06 & 0,34 & 0,11 & 0,33 & 11,1 \\
\hline$d>2,5$ & 64,8 & 8,6 & 86,0 & 3,88 & 2,34 & 2,00 & 0,42 & 0,59 & 0,99 & 0,18 & $<0,10$ & 0,12 & 2,94 \\
\hline Total & 100,0 & 13,3 & 77,2 & 5,82 & 2,45 & 3,88 & 0,65 & 0,79 & 1,65 & 0,26 & $\ldots$ & 0,19 & 6,22 \\
\hline
\end{tabular}


Tabela 5 - Composição química por faixa de densidade do agregado reciclado de Itaquera, tipo vermelho (IT-V)

\begin{tabular}{|c|c|c|c|c|c|c|c|c|c|c|c|c|c|}
\hline \multirow{2}{*}{$\begin{array}{c}\text { Produto/ } \\
\text { Fração }(\mathrm{mm})\end{array}$} & \multicolumn{2}{|c|}{$\%$ Massa } & \multicolumn{11}{|c|}{ Teores (\%) } \\
\hline & Ensaio & Amostra & $\mathrm{SiO}_{2}$ & $\mathrm{Al}_{2} \mathrm{O}_{3}$ & $\mathrm{Fe}_{2} \mathrm{O}_{3}$ & $\mathrm{CaO}$ & $\mathrm{MgO}$ & $\mathrm{Na}_{2} \mathrm{O}$ & $\mathrm{K}_{2} \mathrm{O}$ & $\mathrm{TiO}_{2}$ & $\mathrm{P}_{2} \mathrm{O}_{5}$ & $\mathrm{SO}_{3}$ & PF \\
\hline$-25,4+19,1$ & & & & & & & & & & & & & \\
\hline $\mathrm{d}<1,7$ & 0,6 & 0,2 & $\ldots$ & $\ldots$ & $\ldots$ & $\ldots$ & $\ldots$ & $\ldots$ & $\ldots$ & $\ldots$ & $\ldots$ & $\ldots$ & $\ldots$ \\
\hline $1,7<d<1,9$ & 3,8 & 1,2 & 46,2 & 10,3 & 2,50 & 7,54 & 1,37 & 1,50 & 1,22 & 0,52 & 0,13 & 0,35 & 27,7 \\
\hline $1,9<d<2,2$ & 41,3 & 13,3 & 62,7 & 9,45 & 3,28 & 7,21 & 1,14 & 1,76 & 2,59 & 0,38 & 0,12 & 0,36 & 10,4 \\
\hline $2,2<d<2,5$ & 26,7 & 8,6 & 64,8 & 13,0 & 3,46 & 3,59 & 0,95 & 2,91 & 4,01 & 0,39 & 0,17 & $\ldots$ & 6,75 \\
\hline$d>2,5$ & 27,6 & 8,9 & 67,6 & 8,10 & 2,60 & 9,96 & 1,84 & 0,78 & 1,65 & 0,41 & $\ldots$ & 0,41 & 5,42 \\
\hline $\begin{array}{c}\text { Total } \\
-19,1+12,7\end{array}$ & 100,0 & 32,3 & 63,6 & 10,0 & 3,09 & 6,97 & 1,28 & 1,78 & 2,64 & 0,39 & $\ldots$ & $\ldots$ & 8,65 \\
\hline $\mathrm{d}<1,7$ & 1,0 & 0,4 & $\ldots$ & $\ldots$ & $\ldots$ & $\ldots$ & $\ldots$ & $\ldots$ & $\ldots$ & $\ldots$ & $\ldots$ & $\ldots$ & $\ldots$ \\
\hline $1,7<d<1,9$ & 2,8 & 1,1 & 40,7 & 9,84 & 3,35 & 11,1 & 2,24 & 1,29 & 1,19 & 0,49 & 0,21 & 0,45 & 29,5 \\
\hline $1,9<d<2,2$ & 40,7 & 16,0 & 65,5 & 8,23 & 2,70 & 7,23 & 0,95 & 1,26 & 2,28 & 0,35 & 0,10 & 0,29 & 11,8 \\
\hline $2,2<d<2,5$ & 26,5 & 10,4 & 63,2 & 12,1 & 3,45 & 5,19 & 1,00 & 2,56 & 3,96 & 0,36 & 0,19 & $\ldots$ & 8,18 \\
\hline$d>2,5$ & 29,0 & 11,4 & 68,5 & 5,81 & 2,04 & 13,0 & 2,15 & 0,76 & 1,58 & 0,33 & $\ldots$ & 0,43 & 3,78 \\
\hline $\begin{array}{c}\text { Total } \\
-12,7+9,5\end{array}$ & 100,0 & 39,2 & 64,4 & 8,52 & 2,70 & 8,40 & 1,34 & 1,45 & 2,47 & 0,35 & $\ldots$ & $\ldots$ & 8,90 \\
\hline $\mathrm{d}<1,7$ & 0,4 & 0,0 & $\ldots$ & $\ldots$ & $\ldots$ & $\ldots$ & $\ldots$ & $\ldots$ & $\ldots$ & $\ldots$ & $\ldots$ & $\ldots$ & $\ldots$ \\
\hline $1,7<d<1,9$ & 0,3 & 0,0 & 51,4 & 15,1 & 4,18 & 4,06 & 1,26 & 1,16 & 1,42 & 0,72 & 0,11 & 0,14 & 20,8 \\
\hline $1,9<d<2,2$ & 21,6 & 1,7 & 64,3 & 7,28 & 2,31 & 8,26 & 1,01 & 0,94 & 2,06 & 0,31 & $\ldots$ & 0,31 & 12,5 \\
\hline $2,2<d<2,5$ & 43,5 & 3,4 & 64,3 & 12,0 & 4,30 & 4,84 & 0,90 & 2,66 & 3,46 & 0,40 & 0,15 & $\ldots$ & 7,13 \\
\hline$d>2,5$ & 34,2 & 2,7 & 62,3 & 10,9 & 3,51 & 13,0 & 2,17 & 0,74 & 1,58 & 0,56 & 0,11 & 0,33 & 4,94 \\
\hline $\begin{array}{c}\text { Total } \\
-9,5+4,8\end{array}$ & 100,0 & 7,9 & 63,3 & 10,6 & 3,58 & 8,34 & 1,35 & 1,62 & 2,49 & 0,43 & $\ldots$ & 0,18 & 7,56 \\
\hline$d<1,7$ & 0,9 & 0,1 & $\ldots$ & $\ldots$ & $\ldots$ & $\ldots$ & $\ldots$ & $\ldots$ & $\ldots$ & $\ldots$ & $\ldots$ & $\ldots$ & $\ldots$ \\
\hline $1,7<\mathrm{d}<1,9$ & 0,2 & 0,0 & 48,2 & 10,7 & 2,77 & 7,59 & 1,42 & 1,54 & 1,24 & 0,54 & 0,14 & 0,22 & 24,9 \\
\hline $1,9<d<2,2$ & 11,7 & 0,8 & 67,3 & 8,04 & 2,09 & 3,64 & 0,73 & 1,33 & 2,32 & 0,30 & $\ldots$ & 0,24 & 13,6 \\
\hline $2,2<d<2,5$ & 55,4 & 3,8 & 69,7 & 8,44 & 4,10 & 3,55 & 1,23 & 1,39 & 1,57 & 1,17 & 0,17 & 0,27 & 9,09 \\
\hline$d>2,5$ & 31,8 & 2,1 & 55,9 & 22,6 & 5,29 & 4,57 & 1,23 & 1,39 & 1,57 & 1,17 & 0,17 & 0,27 & 4,63 \\
\hline $\begin{array}{c}\text { Total } \\
-4,8+1,2\end{array}$ & 100,0 & 6,8 & 64,3 & 12,8 & 4,20 & 3,86 & 1,16 & 1,37 & 1,64 & 1,06 & $\ldots$ & 0,26 & 8,15 \\
\hline$d<1,7$ & 1,3 & 0,1 & $\ldots$ & $\ldots$ & $\ldots$ & $\ldots$ & $\ldots$ & $\ldots$ & $\ldots$ & $\ldots$ & $\ldots$ & $\ldots$ & $\ldots$ \\
\hline $1,7<d<1,9$ & 2,9 & 0,2 & 49,6 & 10,2 & 4,18 & 5,45 & 1,20 & 2,34 & 1,78 & 0,86 & 0,13 & 0,45 & 23,8 \\
\hline $1,9<d<2,2$ & 3,9 & 0,2 & 54,4 & 16,4 & 4,10 & 4,11 & 0,82 & 1,25 & 3,05 & 0,79 & 0,11 & 0,21 & 13,8 \\
\hline $2,2<d<2,5$ & 73,8 & 4,5 & 76,4 & 5,07 & 3,32 & 2,30 & 0,58 & 0,77 & 1,14 & 0,24 & 0,68 & 0,10 & 9,71 \\
\hline$d>2,5$ & 18,2 & 1,1 & 72,7 & 8,89 & 4,29 & 3,67 & 1,28 & 1,83 & 2,08 & 0,36 & 0,13 & $\ldots$ & 3,96 \\
\hline $\begin{array}{c}\text { Total } \\
-1,2+0,3\end{array}$ & 100,0 & 6,1 & 73,1 & 6,29 & 3,51 & 2,68 & 0,73 & 1,02 & 1,39 & 0,30 & 0,53 & 0,09 & 9,10 \\
\hline $\mathrm{d}<1,7$ & 1,5 & 0,1 & $\ldots$ & $\ldots$ & $\ldots$ & $\ldots$ & $\ldots$ & $\ldots$ & $\ldots$ & $\ldots$ & $\ldots$ & $\ldots$ & $\ldots$ \\
\hline $1,7<d<1,9$ & 0,2 & 0,0 & 38,7 & 22,4 & 5,73 & 2,00 & 1,40 & 1,02 & 1,57 & 1,63 & 0,21 & 0,63 & 24,5 \\
\hline $1,9<d<2,2$ & 3,2 & 0,1 & 57,8 & 6,95 & 2,45 & 8,24 & 1,44 & 0,65 & 1,52 & 0,36 & $\ldots$ & 0,60 & 19,7 \\
\hline $2,2<d<2,5$ & 18,7 & 0,7 & 61,3 & 9,84 & 3,06 & 6,99 & 1,12 & 1,83 & 2,97 & 0,39 & 0,13 & 0,23 & 11,6 \\
\hline$d>2,5$ & 76,3 & 3,0 & 63,3 & 13,1 & 4,11 & 6,29 & 0,99 & 3,06 & 4,04 & 0,55 & 0,22 & $\ldots$ & 4,06 \\
\hline Total & 100,0 & 4,0 & 61,8 & 12,1 & 3,80 & 6,38 & 1,02 & 2,70 & 3,69 & 0,51 & $\ldots$ & $\ldots$ & 5,96 \\
\hline
\end{tabular}


Tabela 2 - Composição química por faixa de densidade do agregado reciclado de Vinhedo, tipo vermelho (VI-V)

\begin{tabular}{|c|c|c|c|c|c|c|c|c|c|c|c|c|c|}
\hline \multirow{2}{*}{$\begin{array}{c}\text { Produto/ } \\
\text { Fração }(\mathrm{mm})\end{array}$} & \multicolumn{2}{|c|}{$\%$ Massa } & \multicolumn{11}{|c|}{ Teores (\%) } \\
\hline & Ensaio & Amostra & $\mathrm{SiO}_{2}$ & $\mathrm{Al}_{2} \mathrm{O}_{3}$ & $\mathrm{Fe}_{2} \mathrm{O}_{3}$ & $\mathrm{CaO}$ & $\mathrm{MgO}$ & $\mathrm{Na}_{2} \mathrm{O}$ & $\mathrm{K}_{2} \mathrm{O}$ & $\mathrm{TiO}_{2}$ & $\mathrm{P}_{2} \mathrm{O}_{5}$ & $\mathrm{SO}_{3}$ & PF \\
\hline \multicolumn{14}{|l|}{$-25,4+19,1$} \\
\hline$d<1,9$ & 19,6 & 3,1 & $\ldots$ & $\ldots$ & $\ldots$ & $\ldots$ & $\ldots$ & $\ldots$ & $\ldots$ & $\ldots$ & $\ldots$ & $\ldots$ & $\ldots$ \\
\hline $1,9<d<2,2$ & 42,2 & 6,7 & 66,3 & 7,01 & 2,46 & 7,57 & 1,15 & 0,54 & 1,18 & 0,44 & $\ldots$ & 0,29 & 12,4 \\
\hline $2,2<d<2,5$ & 23,6 & 3,8 & 71,6 & 8,78 & 2,46 & 4,53 & 0,77 & 1,48 & 2,16 & 0,32 & $\ldots$ & 0,23 & 7,13 \\
\hline$d>2,5$ & 14,6 & 2,3 & 72,1 & 12,5 & 3,38 & 1,04 & 0,84 & 2,22 & 4,74 & 0,36 & $\ldots$ & $\ldots$ & 2,74 \\
\hline Total & 100,0 & 16,0 & 55,4 & 6,85 & 2,11 & 4,41 & 0,79 & 0,90 & 1,70 & 0,31 & $\ldots$ & 0,18 & 7,31 \\
\hline \multicolumn{14}{|l|}{$-19,1+12,7$} \\
\hline$d<1,9$ & 16,7 & 4,6 & $\ldots$ & $\ldots$ & $\ldots$ & $\ldots$ & $\ldots$ & $\ldots$ & $\ldots$ & $\ldots$ & $\ldots$ & $\ldots$ & $\ldots$ \\
\hline $1,9<d<2,2$ & 44,5 & 12,1 & 64,6 & 6,63 & 2,70 & 8,05 & 1,28 & 0,55 & 1,17 & 0,40 & $\ldots$ & 0,28 & 13,6 \\
\hline $2,2<d<2,5$ & 22,9 & 6,2 & 68,8 & 9,34 & 2,62 & 5,11 & 0,74 & 1,65 & 2,34 & 0,34 & $\ldots$ & 0,17 & 8,27 \\
\hline$d>2,5$ & 15,9 & 4,3 & 67,6 & 13,5 & 4,81 & 1,94 & 1,33 & 2,51 & 4,41 & 0,58 & 0,13 & $\ldots$ & 3,25 \\
\hline Total & 100,0 & 27,3 & 55,3 & 7,24 & 2,57 & 5,06 & 0,95 & 1,02 & 1,76 & 0,35 & 0,02 & $\ldots$ & 8,46 \\
\hline \multicolumn{14}{|l|}{$-12,7+9,5$} \\
\hline $\mathrm{d}<1,9$ & 10,3 & 0,8 & $\ldots$ & $\ldots$ & $\ldots$ & $\ldots$ & $\ldots$ & $\ldots$ & $\ldots$ & $\ldots$ & $\ldots$ & $\ldots$ & $\ldots$ \\
\hline $1,9<d<2,2$ & 24,4 & 1,9 & 60,5 & 9,08 & 3,00 & 7,50 & 1,40 & 0,77 & 1,23 & 0,50 & $\ldots$ & 0,27 & 15,6 \\
\hline $2,2<d<2,5$ & 58,2 & 4,5 & 67,7 & 9,81 & 2,87 & 4,61 & 0,80 & 1,64 & 2,40 & 0,37 & $\ldots$ & 0,17 & 9,28 \\
\hline$d>2,5$ & 7,0 & 0,5 & 66,1 & 13,8 & 5,79 & 2,16 & 1,71 & 2,39 & 4,00 & 0,72 & 0,21 & $\ldots$ & 3,09 \\
\hline Total & 100,0 & 7,7 & 58,8 & 8,90 & 2,81 & 4,67 & 0,93 & 1,31 & 1,98 & 0,39 & $\ldots$ & $\ldots$ & 9,43 \\
\hline \multicolumn{14}{|l|}{$-9,5+4,8$} \\
\hline $\mathrm{d}<1,9$ & 2,6 & 0,2 & $\ldots$ & $\ldots$ & $\ldots$ & $\ldots$ & $\ldots$ & $\ldots$ & $\ldots$ & $\ldots$ & $\ldots$ & $\ldots$ & $\ldots$ \\
\hline $1,9<d<2,2$ & 57,8 & 5,4 & 60,8 & 10,9 & 3,57 & 6,84 & 1,16 & 0,62 & 1,41 & 0,61 & $\ldots$ & 0,18 & 13,5 \\
\hline $2,2<d<2,5$ & 16,4 & 1,5 & 68,9 & 8,86 & 2,51 & 5,30 & 0,82 & 1,73 & 2,33 & 0,36 & $\ldots$ & 0,16 & 8,05 \\
\hline$d>2,5$ & 23,2 & 2,2 & 72,1 & 11,5 & 3,51 & 1,92 & 0,86 & 2,52 & 3,71 & 0,34 & $\ldots$ & $\ldots$ & 3,25 \\
\hline Total & 100,0 & 9,4 & 63,2 & 10,4 & 3,29 & 5,27 & 1,00 & 1,23 & 2,06 & 0,49 & $\ldots$ & $\ldots$ & 9,88 \\
\hline \multicolumn{14}{|l|}{$-4,8+2,4$} \\
\hline $\mathrm{d}<1,9$ & 1,0 & 0,1 & $\ldots$ & $\ldots$ & $\ldots$ & $\ldots$ & $\ldots$ & $\ldots$ & $\ldots$ & $\ldots$ & $\ldots$ & $\ldots$ & $\ldots$ \\
\hline $1,9<d<2,2$ & 27,4 & 1,6 & 59,3 & 12,4 & 3,77 & 6,81 & 1,23 & 0,52 & 1,48 & 0,66 & $\ldots$ & 0,21 & 13,6 \\
\hline $2,2<d<2,5$ & 41,7 & 2,4 & 68,7 & 8,25 & 3,02 & 5,63 & 0,91 & 0,85 & 1,80 & 0,42 & $\ldots$ & 0,13 & 9,78 \\
\hline$d>2,5$ & 29,9 & 1,7 & 77,3 & 8,60 & 3,23 & 1,82 & 0,66 & 1,53 & 2,70 & 0,27 & $\ldots$ & $\ldots$ & 2,86 \\
\hline Total & 100,0 & 5,7 & 68,0 & 9,41 & 3,26 & 4,76 & 0,91 & 0,95 & 1,96 & 0,44 & $\ldots$ & $\ldots$ & 8,66 \\
\hline \multicolumn{14}{|l|}{$-2,4+1,2$} \\
\hline $\mathrm{d}<1,9$ & 0,5 & 0,0 & $\ldots$ & $\ldots$ & $\ldots$ & $\ldots$ & $\ldots$ & $\ldots$ & $\ldots$ & $\ldots$ & $\ldots$ & $\ldots$ & $\ldots$ \\
\hline $1,9<d<2,2$ & 3,1 & 0,2 & 50,1 & 15,7 & 4,33 & 8,64 & 1,54 & 0,47 & 1,62 & 0,99 & 0,13 & 0,18 & 16,7 \\
\hline $2,2<d<2,5$ & 48,1 & 2,4 & 70,1 & 9,21 & 2,84 & 5,14 & 0,80 & 0,60 & 2,08 & 0,41 & $\ldots$ & $\ldots$ & 8,50 \\
\hline$d>2,5$ & 48,3 & 2,4 & 86,9 & 4,60 & 2,83 & 0,89 & 0,26 & 0,50 & 1,24 & 0,17 & $\ldots$ & $\ldots$ & 1,78 \\
\hline Total & 100,0 & 4,9 & 77,2 & 7,14 & 2,87 & 3,17 & 0,56 & 0,54 & 1,65 & 0,31 & $\ldots$ & $\ldots$ & 5,47 \\
\hline \multicolumn{14}{|l|}{$-1,2+0,3$} \\
\hline $\mathrm{d}<1,9$ & 0,2 & 0,0 & $\ldots$ & $\ldots$ & $\ldots$ & $\ldots$ & $\ldots$ & $\ldots$ & $\ldots$ & $\ldots$ & $\ldots$ & $\ldots$ & $\ldots$ \\
\hline $1,9<d<2,2$ & 1,3 & 0,1 & 52,2 & 15,5 & 4,94 & 7,00 & 1,35 & 0,71 & 1,69 & 0,80 & 0,25 & 0,24 & 15,1 \\
\hline $2,2<d<2,5$ & 35,7 & 3,9 & 75,3 & 8,25 & 2,22 & 3,85 & 0,65 & 0,45 & 2,23 & 0,35 & $\ldots$ & $\ldots$ & 5,80 \\
\hline$d>2,5$ & 62,7 & 6,9 & 91,0 & 2,52 & 2,38 & 0,76 & 0,18 & 0,16 & 0,59 & 0,15 & $\ldots$ & $\ldots$ & 1,44 \\
\hline Total & 100,0 & 11,0 & 84,7 & 4,73 & 2,35 & 1,94 & 0,36 & 0,27 & 1,19 & 0,23 & $\ldots$ & $\ldots$ & 3,18 \\
\hline
\end{tabular}

